\title{
Aggregation Study on Lithiated FIVE-MEMBERED HETEROCYCLES - ToWards The Pentuple IoN
}

\author{
Dissertation zur Erlangung des \\ mathematisch-naturwissenschaftlichen Doktorgrades \\ "Doctor rerum naturalium" \\ der Georg-August-Universität Göttingen
}

im Promotionsprogramm Chemie der Georg-August University School of Science (GAUSS)

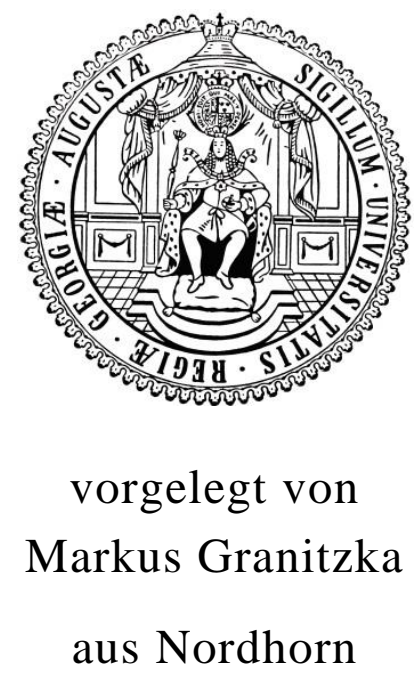

Göttingen, 2013 
Betreuungsauschuss

Prof. Dr. Dietmar Stalke, Institut für Anorganische Chemie

Prof. Dr. George M. Sheldrick, Institut für Anorganische Chemie

Mitglieder der Prüfungskommission

Referent: Prof. Dr. Dietmar Stalke

Korreferent: Prof. Dr. George M. Sheldrick

weitere Mitglieder

Dr. Heidrun Sowa, GZG, Abt. Kristallographie

Jun.-Prof. Dr. Thomas Waitz, Institut für Anorganische Chemie

Dr. Inke Siewert, Institut für Anorganische Chemie

Prof. Dr. U. Diederichsen, Institut für Organische und Biomolekulare Chemie

Tag der mündlichen Prüfung: 15.02.2013 


Meinem Vater 

Geduld und Pfiff zum letzten Knoten! Gewöhnlich geht's am Ende scharf -Mephistopheles, J.W. v. Goethe 



\section{CONTENTS}

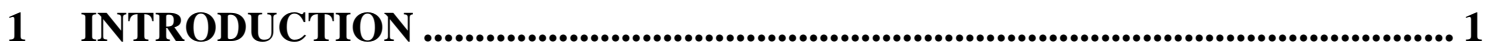

$1.1 \quad$ Aggregation of Lithium Organics..................................................................1

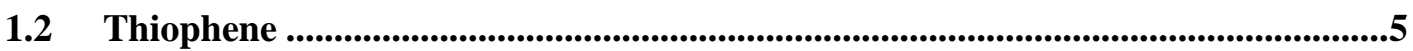

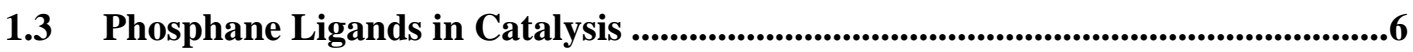

1.4 Scope

2 AGGREGATION OF LITHIATED THIOPHENE ........................................... 11

2.1 Aggregation of 2-Thienyllithium ..................................................................................13

2.2 Aggregation of Methyl-substituted 2-Thienyllithium ...............................................22

2.3 The Pentuple Ion of 2-Thienyllithium (9) …............................................................28

2.4 Aggregation of 2-Furyllithium .............................................................................................34

3 LATE TRANSITION METAL COMPLEXES OF BIS(2-

THIENYL)DIETHYLAMINOPHOSPHANE AND MODIFICATIONS........ 41

3.1 Late Transition Metal Complexes of $\left(\mathrm{SC}_{4} \mathrm{H}_{3}\right)_{2}\left(\mathrm{NEt}_{2}\right) \mathrm{P}(12) \ldots \ldots \ldots . . . . . . . . . . . . . . . . . . . . . . . .43$

3.2 Reduction to Dithienylphosphane (19) ............................................................58

3.3 Sidearm Engineering of P,S-Ligand Systems ....................................................63

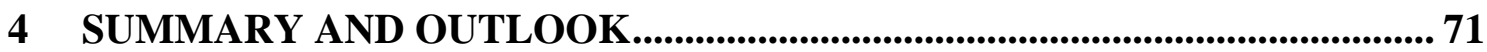

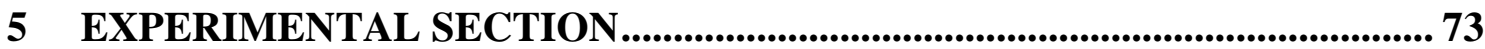

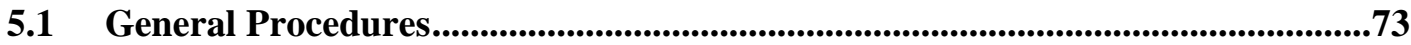

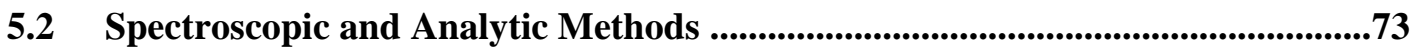

$5.3 \quad$ Elemental Analyses .........................................................................................................74

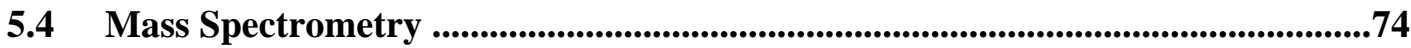

5.5 Synthesis and Characterization ............................................................................................74 


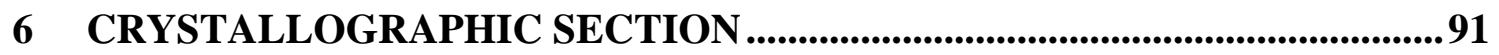

6.1 Crystal Application .................................................................................................................... 91

6.2 Data Collection and Processing ................................................................................. 91

6.3 Structure Solution and Refinement ................................................................................... 92

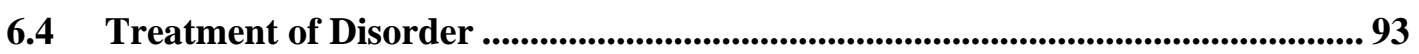

6.5 Crystallographic Details ................................................................................................. 95

6.6 Crystallographic Cooperation...................................................................... 113

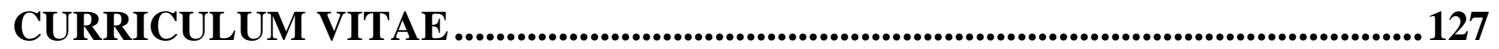

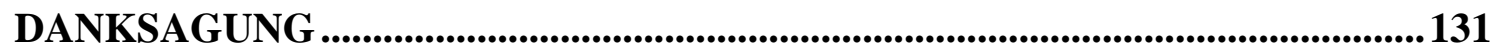

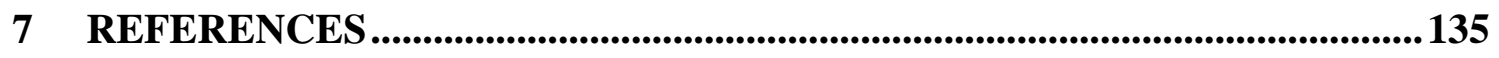




\section{AbBreviations}

\begin{tabular}{|c|c|}
\hline ADP & anisotropic displacement parameters \\
\hline APS & Advanced Photon Source \\
\hline Calcd & calculated \\
\hline CIP & contact ion pair \\
\hline COD & cycloocta-1,5-diene \\
\hline CSD & Cambridge Structural Database \\
\hline DME & 1,2-dimethoxyethane \\
\hline DOSY & diffusion ordered spectroscopy \\
\hline Eq. & Equation \\
\hline eq. & Equivalents \\
\hline $\mathrm{Fu}$ & furyl \\
\hline Fur & furfuryl $\left(\left(\mathrm{C}_{4} \mathrm{H}_{3} \mathrm{O}\right)-2-\mathrm{CH}_{2}-\right)$ \\
\hline GoF & goodness of fit \\
\hline HMPA & hexamethylphosphoric triamide \\
\hline HOESY & $\begin{array}{l}\text { heteronuclear Overhauser } \\
\text { enhancement spectroscopy }\end{array}$ \\
\hline M & metal atom \\
\hline M & molar \\
\hline Me & methyl \\
\hline $\min$. & minimal \\
\hline MS & mass spectrometry \\
\hline NOE & nuclear Overhauser effect \\
\hline PMDETA & $N, N, N^{\prime}, N^{\prime}, N^{\prime}$ '-pentamethyldiethylenetriamine \\
\hline ppm & parts per million \\
\hline $\mathrm{rt}$ & room temperature \\
\hline SSIP & solvent separated ion pair \\
\hline THF & tetrahydrofuran \\
\hline Thi & thienyl \\
\hline TMEDA & $N, N, N^{\prime}, N$ 'tetramethylethylenediamine \\
\hline XRD & $\mathrm{X}$-ray diffraction \\
\hline
\end{tabular}




\section{LIST OF COMPOUNDS}

$1 \quad\left[\left(\mathrm{Et}_{2} \mathrm{O}\right) \mathrm{Li}\left(\mathrm{C}_{4} \mathrm{H}_{3} \mathrm{~S}\right)\right]_{4}$

$2\left[(\mathrm{THF})_{2} \mathrm{Li}\left(\mathrm{C}_{4} \mathrm{H}_{3} \mathrm{~S}\right)\right]_{2}$

$3 \quad\left[(\mathrm{DME}) \mathrm{Li}\left(\mathrm{C}_{4} \mathrm{H}_{3} \mathrm{~S}\right)\right]_{2}$

4 [(TMEDA $\left.) \mathrm{Li}\left(\mathrm{C}_{4} \mathrm{H}_{3} \mathrm{~S}\right)\right]_{2}$

5 [(PMDETA $\left.) \mathrm{Li}\left(\mathrm{C}_{4} \mathrm{H}_{3} \mathrm{~S}\right)\right]$

$6\left[(\mathrm{THF})_{2} \mathrm{Li}\left\{\left(\mathrm{C}_{4} \mathrm{H}_{2} \mathrm{~S}\right)-5-\mathrm{Me}\right\}\right]_{2}$

7 [(DME) $\left.\mathrm{Li}\left\{\left(\mathrm{C}_{4} \mathrm{H}_{2} \mathrm{~S}\right)-5-\mathrm{Me}\right\}\right]_{2}$

8 [(TMEDA)Li $\left.\left\{\left(\mathrm{C}_{4} \mathrm{H}_{2} \mathrm{~S}\right)-4-\mathrm{Me}\right\}\right]_{2}$

$9\left[\mathrm{Li}(\text { Diglyme })_{2}\right]\left[(\right.$ Diglyme $\left.) \mathrm{Li}_{2}\left(\mathrm{C}_{4} \mathrm{H}_{3} \mathrm{~S}\right)_{3}\right]$

10 [(PMDETA $\left.)_{2} \mathrm{Li}_{6} \mathrm{O}_{2}\left\{\left(\mathrm{C}_{4} \mathrm{H}_{2} \mathrm{O}\right)-5-\mathrm{Me}\right\}_{4}\right]$

$11\left[\left\{\mathrm{Li}(\mathrm{DME})_{2}\right\}_{2} \mathrm{Li}_{12}\left\{\left[\mathrm{C}_{4} \mathrm{H}_{3} \mathrm{O}\right]_{8}\left[\mathrm{OCH}_{3}\right]_{6}\right\}\right]$

$12\left(\mathrm{SC}_{4} \mathrm{H}_{3}\right)_{2}\left(\mathrm{NEt}_{2}\right) \mathrm{P}$

$13\left[\left(\mathrm{SC}_{4} \mathrm{H}_{3}\right)_{2}\left(\mathrm{NEt}_{2}\right) \mathrm{PNiCl}_{2}\right] \cdot\left(\mathrm{C}_{7} \mathrm{H}_{8}\right)$

$14\left[\left(\mathrm{SC}_{4} \mathrm{H}_{3}\right)_{2}\left(\mathrm{NEt}_{2}\right) \mathrm{PCuCl}(\mathrm{MeCN})\right]_{2}$

$15\left[\left\{\left(\mathrm{SC}_{4} \mathrm{H}_{3}\right)_{2}\left(\mathrm{NEt}_{2}\right) \mathrm{P}\right\}_{2} \mathrm{PdCl}_{2}\right]$

$16\left[\left(\mathrm{SC}_{4} \mathrm{H}_{3}\right)_{2}\left(\mathrm{NEt}_{2}\right) \mathrm{PCl}\right]_{2} \cdot\left(\mathrm{C}_{7} \mathrm{H}_{8}\right)$

$17\left[\left(\mathrm{SC}_{4} \mathrm{H}_{3}\right)_{2}\left(\mathrm{NEt}_{2}\right) \mathrm{PIrCl}(\mathrm{COD})\right] \cdot\left(\mathrm{C}_{7} \mathrm{H}_{8}\right)$

$18\left[\left(\mathrm{SC}_{4} \mathrm{H}_{3}\right)_{2}\left(\mathrm{NEt}_{2}\right) \mathrm{PAuCl}\right]$

$19\left(\mathrm{SC}_{4} \mathrm{H}_{3}\right)_{2} \mathrm{PH}$

$20 \mathrm{Thi}_{2} \mathrm{PCl}$

$21 \mathrm{Thi}_{4} \mathrm{P}_{2}$

$22 \mathrm{Thi}_{2} \mathrm{P}(\mathrm{O}) \mathrm{OH}$

$23\left[\left\{(\mathrm{FurPh})_{2} \mathrm{P}_{2}\right\} \mathrm{Au}_{2} \mathrm{Cl}_{2}(\mathrm{FurPhPH})\right]$ 


\section{INTRODUCTION}

\subsection{Aggregation of Lithium Organics}

Since Schlenk, Holtz, and Thal enabled to handle lithium organics under laboratory conditions in the early beginning of the last century, these reagents gained importance in various fields of research. ${ }^{[1]}$

In synthetic chemistry lithium organics became one of the most prominent metallation and deprotonation reagents and are widely applied. ${ }^{[2]}$

$$
-\mathrm{R}-\mathrm{Li}]_{\mathrm{n}}
$$

a<smiles></smiles>

d

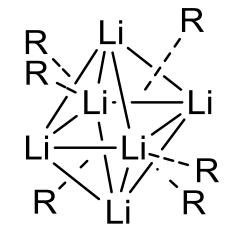

b

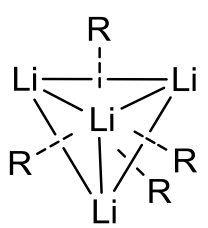

c<smiles>[R][AlH]1[R][Tl]1</smiles><smiles>[R][Al]([3H])[3H]</smiles>

Figure 1-1. Known aggregation motifs of lithium organics. $\mathbf{a}=$ oligomer, $\mathbf{b}=$ hexamer, $\mathbf{c}=$ tetramer, $\mathbf{d}=$ trimer, $\mathbf{e}=$ dimer, $\mathbf{f}=$ triple ion, $\mathbf{g}=$ contact ion pair $(\mathrm{CIP}), \mathbf{h}=$ solvent separated ion pair $(\mathrm{SSIP}) ; \mathrm{R}=$ alkyl, aryl or any organic residue.

Until now a lot of knowledge was gained on the aggregation state of lithium organics in the solid state. The aggregation and deaggregation can be controlled by adding the adequate donor base. The infinite solid-state structure of phenyllithium $[\mathrm{PhLi}]_{\infty}{ }^{[3]}$ (see Figure $1-1, \mathbf{a})$ is broken down, e.g. into the tetramer $\left[\left(\mathrm{Et}_{2} \mathrm{O}\right) \mathrm{LiPh}_{4}{ }^{[4]}(\mathbf{c})\right.$ in diethyl ether $\left(\mathrm{Et}_{2} \mathrm{O}\right)$. While the addition of $N, N, N^{\prime}, N^{\prime}$-tetramethylethylene-1,2-diamine (TMEDA) leads to the dimer $\left[(\mathrm{TMEDA}) \mathrm{LiPh}_{2}{ }^{[5]}(\mathbf{e})\right.$, the addition of the tridentate donor base $N, N, N^{\prime}, N^{\prime \prime}, N^{\prime \prime}$-pentamethyldiethylenetriamine (PMDETA) results in the monomer $[(\mathrm{PMDETA}) \mathrm{LiPh}]^{[6]}(\mathbf{g})$, respectively. From a $n$-pentane solution $n$-BuLi crystallizes as the hexamer $\left[n \mathrm{BuLi}_{6}{ }^{[7]}(\mathbf{b})\right.$. Additionally, Strohmann et al. obtained a trimer (d) of $t$-BuLi with 1,2,3-trimethyl-1-3-5-triazacyclohexane by cutting off a hypothetical edge of a $t$-BuLi tetramer $(\mathbf{c})$ (see Scheme 1-1). ${ }^{[8]}$ 


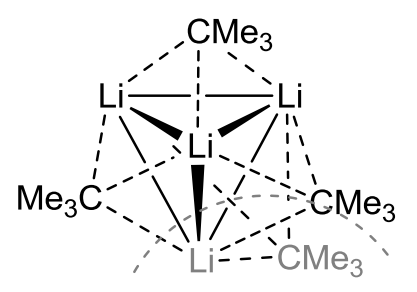

$(t \mathrm{BuLi})_{4}$

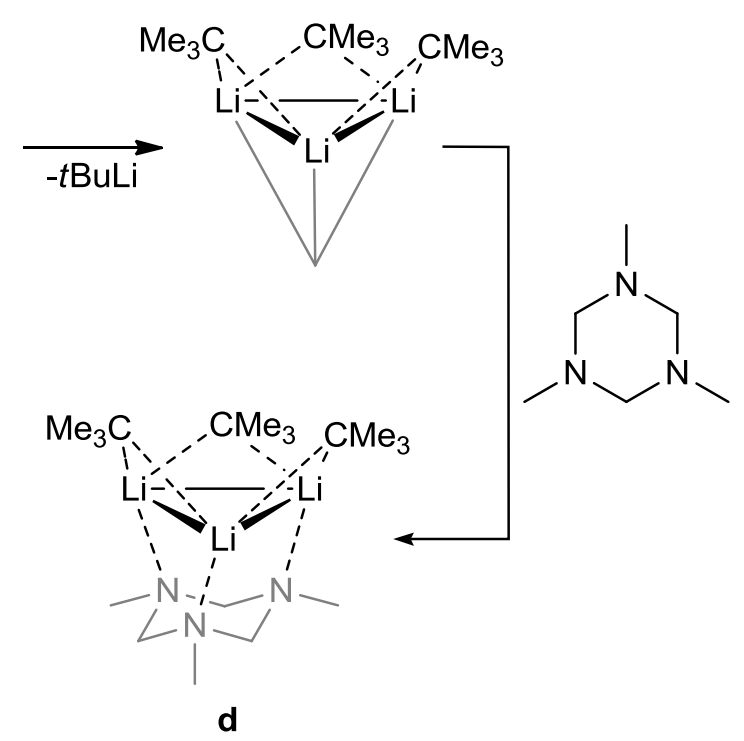

Scheme 1-1. Deaggregation of tetrameric $t$-BuLi with triazacyclohexane to the trimer $\mathbf{d}^{[8]}$

Wittig was the first to report a so called triple ion in 1958, the lithium lithiate aggregate (f) in phenyllithium (Figure 1-1). ${ }^{[9]} \operatorname{In}\left[\operatorname{Li}\left\{\operatorname{Li}\left(\mathrm{C}_{6} \mathrm{H}_{5}\right)_{2}\right\}\right]$ one lithium cation acts as the coordination center of the complex anion and the second one as the cationic counter ion. Since then, many lithium lithiates have been described in which one lithium cation is coordinated by two carbanions while the second lithium atom is coordinated by solvent molecules. In Figure 1-2 lithium cyclopentadienyl ${ }^{[10]}$ (i, left) and tris(trimethylsilyl)methyllithium ${ }^{[11]}$ (j, right) are shown as examples of triple ions.
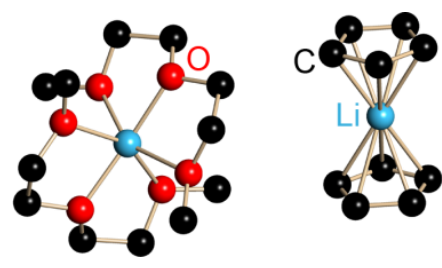

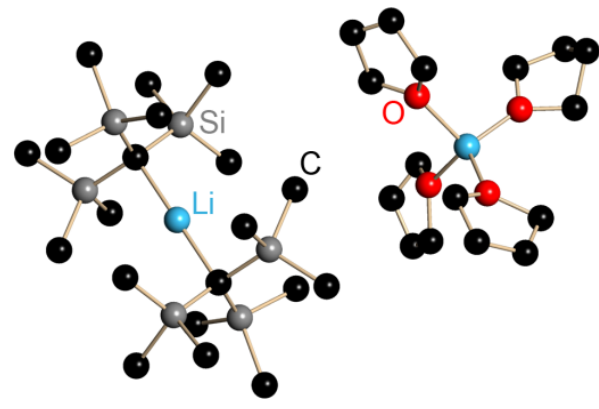

j

Figure 1-2. Examples of lithium lithiate compounds. $\left[\operatorname{Li}(\mathrm{cp})_{2}\left(\operatorname{Li}(\text { diglyme })_{3}\right)\right]^{[10]} \mathbf{i}($ left $)$, $\left[\mathrm{Li}\left(\mathrm{CSiMe}_{3}\right)_{2}\left(\mathrm{Li}(\text { thf })_{4}\right)\right]^{[11]} \mathbf{j}$ (right).

Due to its reaction behaviour with aldehydes (vide infra) the tris(trimethylsilyl)methyllithium $\left(\left(\mathrm{Me}_{3} \mathrm{Si}\right)_{3} \mathrm{CLi}\right)$ attracted Reich's attention. He found out that in an ethereal solution ( $\mathrm{THF}: \mathrm{Et}_{2} \mathrm{O}, 3: 2$ ) of tris(trimethylsilyl)methyllithium an equilibrium 
of the triple ion, the contact ion pair and the separated ion is favoured when adding hexamethylphosphoric triamide (HMPA) (Scheme 1-2). ${ }^{[12]}$

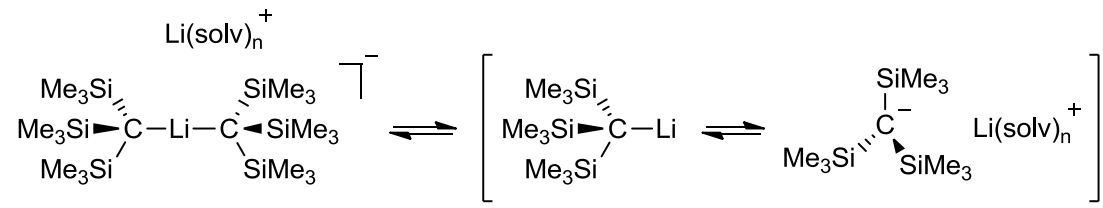

a

b

c

Scheme 1-2. Equilibrium between the triple ion a (left), CIP $\mathbf{b}$ (center) and SSIP $\mathbf{c}$ (right) of ( $\left.\mathrm{SiMe}_{3}\right) \mathrm{CLi}$ (solv = HMPA).

He proposed a mechanism for the reaction of $\left(\mathrm{Me}_{3} \mathrm{Si}\right)_{3} \mathrm{CLi}$ with aldehydes in which the formation of the triple ion is crucial to the reaction progress to form the Peterson product $^{[13]}$ (Scheme 1-3). In the first step the aldehyde reacts with the triple ion of $\left(\mathrm{Me}_{3} \mathrm{Si}\right)_{3} \mathrm{CLi}$. This intermediate dissociates to the SSIP and thus allows a new aldehyde to attack the SSIP leading to the desired product, instead of direct formation of the product via the intermediate.

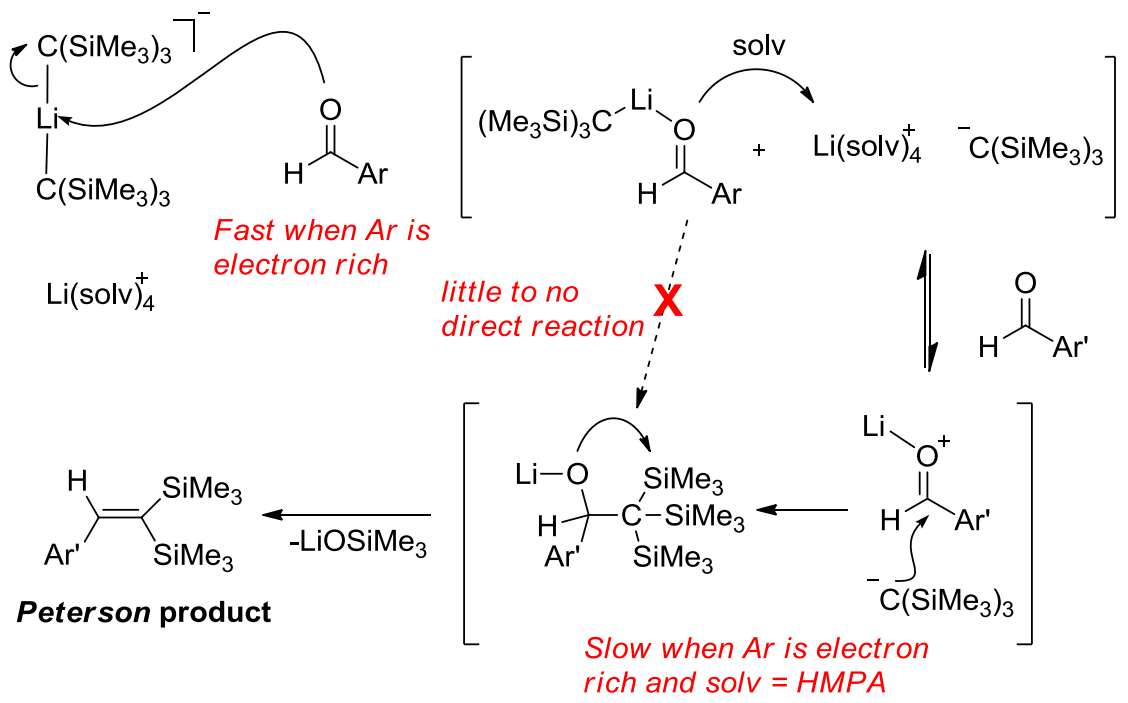

Scheme 1-3. Proposed reaction mechanism for the reaction of $\left(\mathrm{SiMe}_{3}\right)_{3} \mathrm{CLi}$ with an electron rich aldehyde in the presence of HMPA to form the Peterson product. ${ }^{[12]}$

Since not only the SSIPs and CIPs take part in reactions it seems essential that the triple ion is present as well. In order to fully understand the reaction pathways of lithium organics it will be necessary to further investigate the aggregation states in solution as well as in the solid state. Only then the full potential of these highly interesting compounds can be accessed. 
The utilization of donor bases when reacting lithium organics and the consequent deaggregation of higher oligomers raised lithium organic chemistry to a new level. Reactions that were previously not possible at room temperature or even higher temperatures can now be easily performed at ambient conditions by applying donor bases, e.g. the metallation of benzene with $n$-BuLi in hydrocarbons is rather negligibly at room temperature. The addition of TMEDA to this reaction mixture, which breaks up the higher aggregate (hexamer) of $n$-BuLi, proceed the lithiation almost quantitative. ${ }^{[14]}$

Last year, Stalke et al. reported a convenient way for the metallation of toluene to form benzyllithium. ${ }^{[15]}$ Hexameric trimethylsilylmethyllithium can easily be deaggregated by the $\mathrm{O}, \mathrm{N}$-donor base $\mathrm{Me}_{2} \mathrm{~N}\left(\mathrm{CH}_{2}\right)_{2} \mathrm{OMe}$ to form a dimer. This aggregate is able to lithiate toluene at the methyl group, opening a promising way for the neat metallation of toluene since benzyllithium is a bulk material in many fields.

In 2004, the next stage of lithium organic chemistry was achieved. ${ }^{[16]}$ Knochel et al. propagated the addition of lithium chloride to Grignard reagents ${ }^{[17]}$ forming so called Turbo-Grignard reagents. The postulated mechanism of the formation of $i \mathrm{PrMgCl} \cdot \mathrm{LiCl}$ is shown in Scheme 1-4. $\mathrm{LiCl}$ inserts into the dimeric aggregate of the pure magnesium compound a (left), resulting in the more reactive magnesiate complex $\left[i \mathrm{PrMgCl}_{2} \mathrm{Li}^{+}\right] \mathbf{b}$ (center). This complex is the primordial Turbo-Grignard compound and can transform a large variety of aryl- and heteroaryl Grignard reagents from the corresponding bromides $\mathbf{c}$ (right).

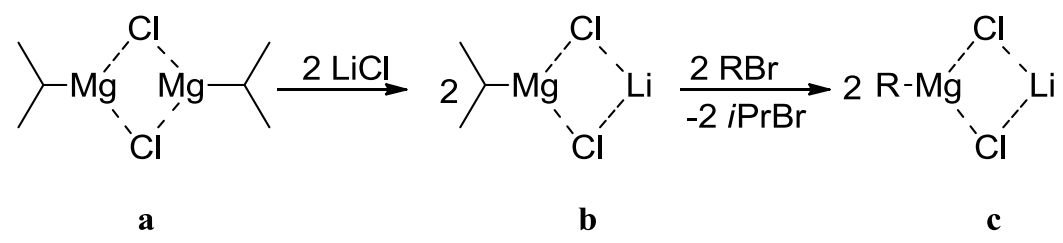

Scheme 1-4. Br/Mg exchange in Turbo-Grignards propagated by $\mathrm{LiCl}$.

$i \mathrm{PrMgCl} \cdot \mathrm{LiCl}$ is nowadays commercially available ${ }^{[18]}$ and opened up a new field of the application of Grignard reagents in organic synthesis, especially due to their tolerance of functional groups. ${ }^{[19]}$

Mulvey stated "To date only a glimmer of light has been cast on this structural darkness and $^{,[20]}$ only a few solid-state structures of Turbo-Grignards have been elucidated. ${ }^{[21]}$ The understanding of the reaction behaviour of $\mathrm{Li} / \mathrm{Li}$ or mixed metal reagents is 
strongly correlated to their aggregation in the solid state and moreover in solution. The necessity of the structural information of these highly sensible and demanding compounds should be the main topic of research in future investigations. Only then more light can be shed on the comprehension of lithium organic chemistry.

\subsection{Thiophene}

Thiophene, the sulfur-containing five-membered aromatic heterocycle (Figure 1-3), is one of the most versatile scaffolds in various chemical areas, covering a wide range from organic synthesis via organometallic chemistry and materials to life science.

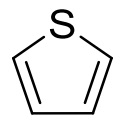

Figure 1-3. Thiophene.

In organic synthesis both carbon atoms next to the sulfur atom are readily accessible to derivatization, ${ }^{[22]}$ normally starting from a mono- or di-halogenated or -metallated species. ${ }^{[23]}$ Recently a hetero-s-block-metallated thienyl complex, [(TMEDA) ${ }_{2} \mathrm{Na}$,$\left.\mathrm{Mg}\left(\mathrm{C}_{4} \mathrm{H}_{3} \mathrm{~S}\right)_{3}\right]$, was published. ${ }^{[24]}$ Transition metal thienyl complexes were equally appealing and have been synthesized in past decades in vast variety. More recently, they attracted attention because of their functionality in terms of redox activity, magnetic and fluorescent capability and opto-electronical performance. ${ }^{[25]}$ Since the award of the chemistry Nobel Prize to Heeger, MacDiarmid, and Shirakawa for the discovery and development of conductive polymers in 2000, polythiophenes (PTs) are one of the most flourishing areas in materials science. ${ }^{[26]}$ They are key candidates for conducting polymers, opto-electronical luminescent layers, sensors, absorber and many other applications. ${ }^{[27]}$ Even in anti-cancer therapy 2,3-disubstituted thiophenes function as signal attenuators in enzyme tracing, ${ }^{[28]}$ and thienyl-substituted titanocenes show a considerably improved cytotoxicity against pig kidney cells. ${ }^{[29]}$

In all these areas it is essential to get information about the lithiated species in the solid state but even more important in solution, because structural changes in solution like solvation and aggregation determine the reactivity as well as selectivity and hence the product range in organic syntheses and the materials profile of PTs. 2- 
Monometallation needs to be tuned, i.e. favoured or discriminated against 2,5dimetallation (Figure 1-4, left), leaving the thienyl group either in a pendent or bridging position in the product. ${ }^{[30]}$ Even the 3-position can be favoured above the 2-position and substituted first while the other remains metallated (center). ${ }^{[31]}$
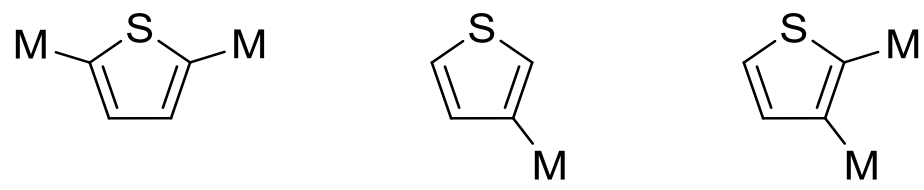

Figure 1-4. Metallation of thiophene in 2-, 5-position (left), 3-position (center) and 2-,3-position (right).

Accordingly, beside the well-established issues of solvation and aggregation, valid for any lithium organics, thiophene is a particularly challenging substrate because of potential mono- and di-metallation in the 2- and/or 3-position (right).

\subsection{Phosphane Ligands in Catalysis}

Phosphane ligands are a key tuner to numerous transition metals used in catalytic processes. ${ }^{[32]}$ Ligand design has been in the focus over the last half century and gains more and more importance in a large variety of synthetic applications. To most of these catalytically active metals a phosphane ligand is introduced to fine tune the electronic and steric properties of the complexes to increase their catalytic efficiency. Among phosphane ligands, triphenylphosphane is convenient and widely used but several other systems are applied. Those tailor-made systems contain ligands that are capable of binding the active metal tightly without blocking its catalytic properties.

Since the requirements in chemistry are very divergent, reaching from a potent pharmaceutical to a tough polymeric plastic, almost every metal of the periodic table of the elements is applied in organic synthesis to generate the target molecule.

Transition metals are widely used and show a special capacity in a certain field of organic or organometallic reactions. ${ }^{[33]}$ Among the late transition metals palladium chemistry is towering out and most rewarded ${ }^{[34]}$ but raising interests in nickel ${ }^{[35]}$, copper $^{[36]}$, iridium $^{[37]}$ and gold ${ }^{[38]}$ show that they are in no way inferior to it. 


\subsubsection{Hemilabile Ligands}

In catalytic processes it is very important that the ligand is tightly bonded to the active metal atom without blocking the active center to keep the catalyst intact. This can be provided by one strongly bonded donor atom and a second weaker bonded donor atom. This weaker bonded atom can open a site of the metal atom when a substrate is approaching and propagate the bond formation to the active center.

These specific ligands are so called hemilabile ligands and first mentioned by Jeffrey and Rauchfuss. ${ }^{[39]}$ They investigated the donor properties of $P, O$ - and $P, N$-ligands whereas one donor atom-metal bond is cleaved during the catalytic cycle. In these complexes the donor atoms vary in their Pearson hardness ${ }^{[40]}$, indispensable in a hemilabile ligand. In Scheme 1-5 catalytic cycle with a hemilabile ligand is shown.

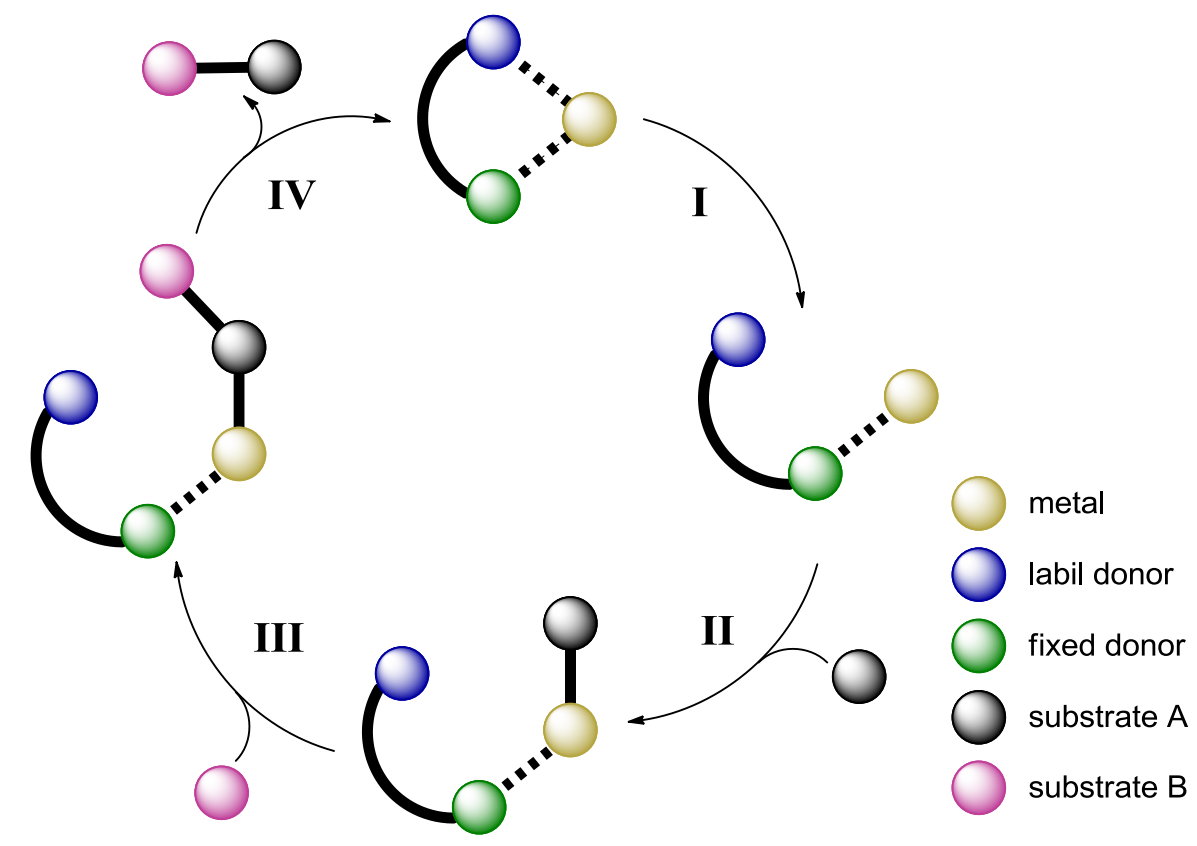

Scheme 1-5. Catalytic cycle with a hemilabile ligand.

In the stable but inactive complex (top) the hemilabile bond is cleaved (I) and a vacant coordination site is generated by a primary dissociation step (right). An appropriate substrate can bind to the metal atom (II) to form the substrate bonded complex (bottom). In the next step (III) another reagent can form a new bond with the activated substrate (left). This mostly short-lived species dissociates in a reductive elimination (IV) releasing the newly formed product and the weaker donor atom binds to the metal atom again. The catalyst is now restored to enter the next catalytic cycle. 
Many examples of hemilabile ligands and metal complexes containing hemilabile ligands have been in the focus of the Stalke group over the last years, either on account of their unusual coordination motifs or due to their electronic properties.

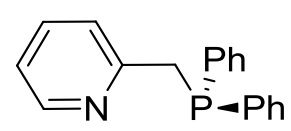

a<smiles>[H][Y]([H])(c1ccccn1)c1ccccn1</smiles>

$\mathrm{X}=\mathrm{C}, \mathrm{N}, \mathrm{P}$

b

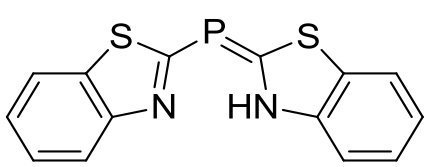

C

Figure 1-5. Examples of hemilabile ligands.

A tin complex of diphenyl(2-picolyl)phosphane (Figure 1-5, a, left) shows a temperature depending hemilabile character in solution. While the tin atom is exclusively coordinated by the nitrogen atom at ambient temperature (Figure 1-6, d, left) the phosphorus atom coordinates as well when cooled down to $193 \mathrm{~K}$ (e, right). ${ }^{[41]}$<smiles>Cl[SnH](Cl)c1ccccc1CPc1ccccc1</smiles>

$273 \mathrm{~K}$<smiles></smiles>

$193 \mathrm{~K}$

d

e

Figure 1-6. Coordination modes of diphenyl(2-picolyl)phosphane to tin chloride at ambient temperature (d, left) and low temperature (e, right).

The sulfur or selenium oxidized ligands of a also displays an enhanced hemilabile character compared to the known diphenyl(2-picolyl)iminophosphoranes. ${ }^{[42]}$ The structural motifs of the anionic ligands (Figure 1-5, b) with a central carbon, nitrogen or phosphorus atom, respectively, and 2-pyridyl substituents, e.g. di(2-pyridyl)methyl ${ }^{[43]}$, amide $^{[44]}$, and - phosphanide ${ }^{[45]}$ have been investigated. The secondary phosphane di(2benzothiazolyl)phosphane (c) is a versatile ligand to coordinate metals in unexpected coordination motifs, due to its potential to coordinate in a $P-, P, N$ - or $N, N$-mode to metal ions. ${ }^{[46]}$ The sulfur atoms are also probable donor sites and $P, S-, N, S-$ or $S, S-$ motifs are possible. These ligands are further feasible to coordinate two metal ions via the phosphorus and the nitrogen atom. Ligands, which are capable of coordinating metal 
atoms with two donor sites "looking" in opposite directions, are so called Janus head ligands. ${ }^{[47]}$ The name originates from the ancient roman god Janus, who is embodied with two heads facing in opposite directions (Figure 1-7).

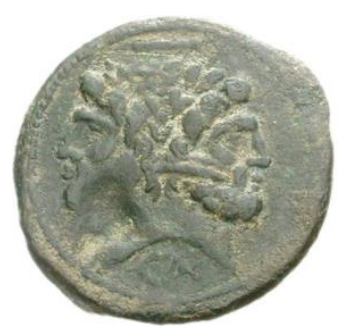

Figure 1-7. Bronze coin depicting a laureate Janus (ca. 200 BC). ${ }^{[18]}$

The lithiation of di(2-benzothiazolyl)phosphane for example afforded the $N, N$-coordinated lithium complex $\mathbf{f}$ (Scheme 1-6), in which the divalent phosphorus atom of the phosphane should be regarded as a potential 4-electron donor. The addition of the soft metal manganese led to a coordination polymer $\mathbf{g}$. Two manganese ions are $\mu$-bridged by the phosphorus atom and the lithium atom is coordinated by the nitrogen face of the Janus head ligand in the same manner as in the starting material f. Furthermore the diethyl ether molecules are replaced by the carbon oxide molecules of the manganese fragment leading to coordination polymer strains.

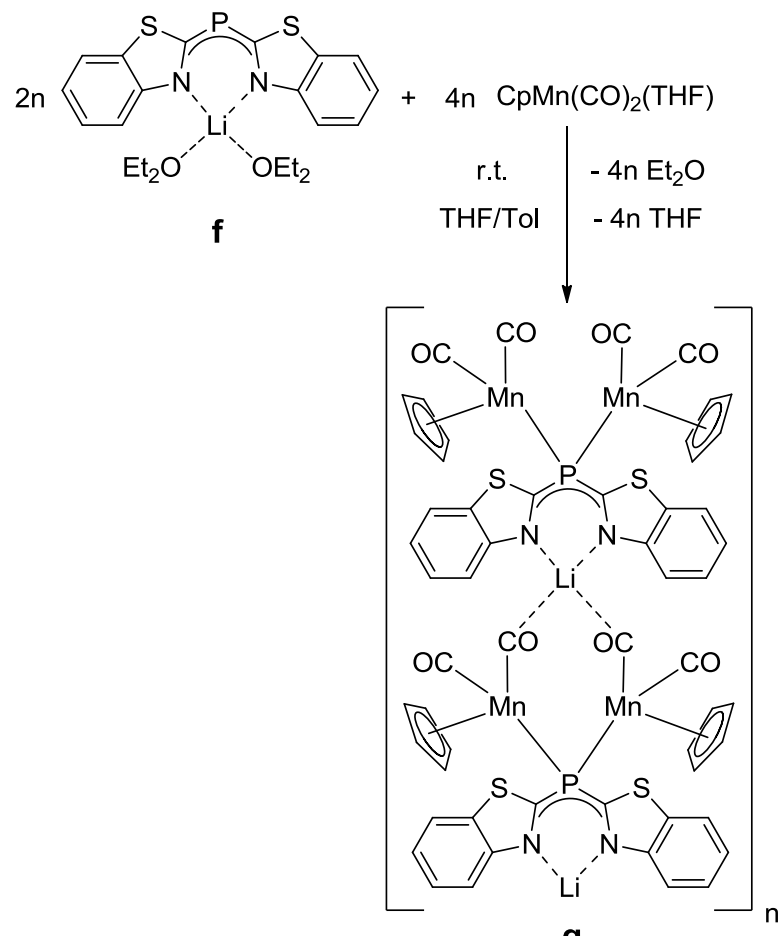

g

Scheme 1-6. Hetero bimetallic Janus head complexe of $\mathrm{P}(\mathrm{bth})_{2}{ }^{-}$. 


\subsection{Scope}

The main work of this thesis is divided into two parts (Chapter 2 and 3) followed by a sum up of main findings and a short outlook in Chapter 4 proceeded by the experimental section in Chapter 5.

Chapter 2 focuses on the elucidation of the aggregation of 2-thienyllithium, methylsubstituted 2-thienyllithium and 2-furyllithium in the solid state and in solution. The addition of an adequate donor base to lithium organics reduces their aggregation. Their solid-state structures should be determined by single crystal X-ray diffraction experiments and their coordination behaviour in solution by means of multi nuclear NMR techniques. For many lithium organics the deaggregation proceeded by going from oligomers to monomers, via hexamers, tetramers and dimers. The investigations of the established aggregation ladder should take one step further by searching for yet unknown, however theoretically predicted, aggregates in between the established rungs of the ladder.

The scope of Chapter 3 is to develop synthetic routes and structurally investigate the coordination behavior of bis(2-thienyl)diethylaminophosphane in late transition metal complexes using single crystal X-ray diffraction. The study will shine light on different coordination geometries by forming complexes with different metals, and it will be investigated if different metals coordinate selectively to the soft sulfur or phosphorus coordination site. Moreover, the transformation of bis(2-thienyl)diethylaminophosphane to the bis(2-thienyl)phosphane, a promising $P, S$-ligand, is another interest, and the effect of variation/elongation of the heterocyclic side arms shall be examined by challenging syntheses of heterocyclic substituted phosphanes. 


\section{Aggregation OF Lithiated THIOPHENE}

Prior to this thesis several structures of 2-thienyllithium derivatives have already been reported in the literature and structurally described. Firstly, tetramers of 2-thienyllithium with and without donating side-arms in the 5-position, i.e. [(THF $)_{2}\left\{\mathrm{Li}\left(\mathrm{C}_{4} \mathrm{H}_{2} \mathrm{~S}\right)-\right.$ $\left.3-\mathrm{OMe})\}_{4}\right],{ }^{[48]}$ and $\left[\left(\mathrm{Et}_{2} \mathrm{O}\right) \mathrm{Li}\left\{\left(\mathrm{C}_{4} \mathrm{H}_{2} \mathrm{~S}\right)-5-\mathrm{Me}\right\}\right]_{4},{ }^{[49]}$ respectively were reported. Additionally there are the dimers, also with and without donating side-arms in the 3-position, i.e. $\left.\left[(\mathrm{THF}) \mathrm{Li}\left\{\left(\mathrm{C}_{4} \mathrm{H}_{2} \mathrm{~S}\right)-3-\mathrm{CH}_{2} \mathrm{OMe}\right) \mathrm{S}\right\}\right]_{2},{ }^{[50]} \quad\left[(\mathrm{TMEDA}) \mathrm{Li} \cdot \mathrm{Li}\left\{\left(\mathrm{C}_{4} \mathrm{H}_{2} \mathrm{~S}\right)-\right.\right.$ 3- $\left.\left.\left.\mathrm{CH}_{2} \mathrm{NMe}_{2}\right\}_{2}\right],{ }^{[51]} \quad\left[(\mathrm{THF}) \mathrm{Li} \cdot \mathrm{Li}\left\{\left(\mathrm{C}_{4} \mathrm{H}_{2} \mathrm{~S}\right)-3-\mathrm{S}(\mathrm{N} t \mathrm{Bu})_{2} \mathrm{~S}\right)\right\}\right]_{2},{ }^{[31]}$ $\left[(\mathrm{TMEDA}) \mathrm{Li}\left(\mathrm{C}_{4} \mathrm{H}_{3} \mathrm{~S}\right)\right]_{2}{ }^{[52]}$ and $\left.\left[(\mathrm{TMEDA}) \mathrm{Li}\left\{\mathrm{C}_{4} \mathrm{H}_{2} \mathrm{~S}\right)-3-\mathrm{Br}\right\}\right]_{2} \cdot{ }^{[53]}$ Furthermore the structure of the dimeric 2-lithiated benzothiophene $\left[(\mathrm{TMEDA}) \mathrm{Li}\left(\mathrm{C}_{8} \mathrm{H}_{5} \mathrm{~S}\right)\right]_{2}$ has been determined. ${ }^{[54]}$ Within my diploma thesis I was able to elucidate the structures of the dimer $\left[(\mathrm{THF})_{2} \mathrm{Li}\left(\mathrm{C}_{4} \mathrm{H}_{3} \mathrm{~S}\right)\right]_{2}$ and the first monomer of 2-thienyllithium [(PMDETA $\left.) \mathrm{Li}\left(\mathrm{C}_{4} \mathrm{H}_{3} \mathrm{~S}\right)\right]$. As confirmed by this series of structures, no clear one-to-one relation between donor base and aggregation state can be drawn.

First of all the synthesis and low-temperature crystallization of 2-thienyllithium aggregates 1-5 is described (Scheme 2-1). To study the aggregation state, three different oxygen and two nitrogen donor bases have been selected, named $\mathrm{Et}_{2} \mathrm{O}$, THF, dimethoxyethane (DME), TMEDA, and PMDETA to study the aggregation state. The lithium derivatives were obtained by a straightforward reaction of thiophene and $n$-BuLi in a 1:1 stoichiometric ratio in diethyl ether at $0{ }^{\circ} \mathrm{C}$, followed by the addition of the donor bases THF, DME, TMEDA or PMDETA, respectively (Scheme 2-1). Indicated by the $\mathrm{pK}_{\mathrm{a}}$ of thiophene (33) compared to that of benzene $(44)^{[55]}$ the heterocycle is readily metallated at the carbon atom next to the sulfur atom but 2,5- and 2,3dilithiation are also feasible by adding two equivalents of the organolithium compound.

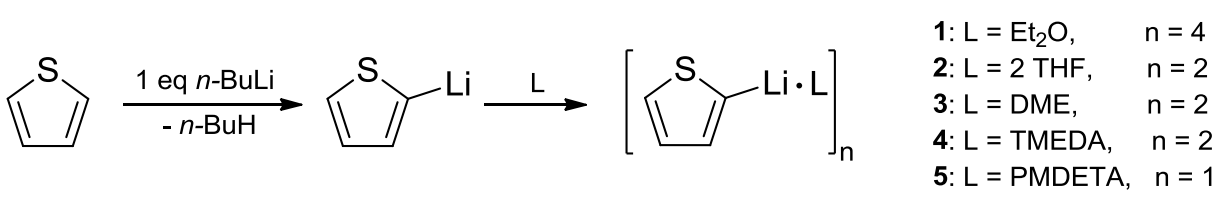

Scheme 2-1. Preparation of 2-thienyllithium derivatives 1-5 via the reaction with $n$-BuLi at $0{ }^{\circ} \mathrm{C}_{\text {in }} \mathrm{Et}_{2} \mathrm{O}$ followed by the addition of the respective donor base.

The results of the deaggregation and structural comparison between the different 2thienyllithium molecules are being discussed in the next chapters. Some of the results 
presented in this chapter arose during the work of Klas Eike Schwarze under my guidance. Multidimensional NMR experiments were performed in cooperation with Ann-Christin Pöppler and the results were adapted to explain the observations in mononuclear NMR spectra. For further details on the NMR experiments see the recently published article ${ }^{[56]}$ and the $\mathrm{PhD}$ thesis of Pöppler. ${ }^{[57]}$ 


\subsection{Aggregation of 2-Thienyllithium}

\subsection{1 $\quad\left[\left(\mathrm{Et}_{2} \mathrm{O}\right) \mathrm{Li}\left(\mathrm{C}_{4} \mathrm{H}_{3} \mathrm{~S}\right)\right]_{4}(\mathbf{1})$}

The starting point of this investigation was the tetramer which was isolated from the parent reaction mixture upon storing the clear solution at $5{ }^{\circ} \mathrm{C}$. As in all further cases crystals were selected and transferred to the diffractometer at cryogenic conditions applying the XTEMP-2 device. ${ }^{[58]} \mathbf{1}$ crystallizes in the triclinic space group $\mathrm{P} \overline{1}$ with one tetramer in the asymmetric unit (Figure 2-1). The four lithium atoms form a tetrahedron, the common structural motif for $[\mathrm{LiR}]_{4}$ oligomers. ${ }^{[59]}$ All four almost equilateral $\mathrm{Li}_{3}$ triangles are $\mu_{3}$-capped by the $\mathrm{C}_{\alpha}$-atom of the thienyl anion. The average $\mathrm{Li}-\mathrm{C}$ bond length of 2.282(4) $\AA$ is within the range found for the similar tetramer $\left[\left(\mathrm{Et}_{2} \mathrm{O}\right) \mathrm{Li}\left\{\left(\mathrm{C}_{4} \mathrm{H}_{2} \mathrm{~S}\right)-5-\mathrm{Me}\right\}\right]_{4}($ av. $2.269(14) \AA) .{ }^{[49]}$

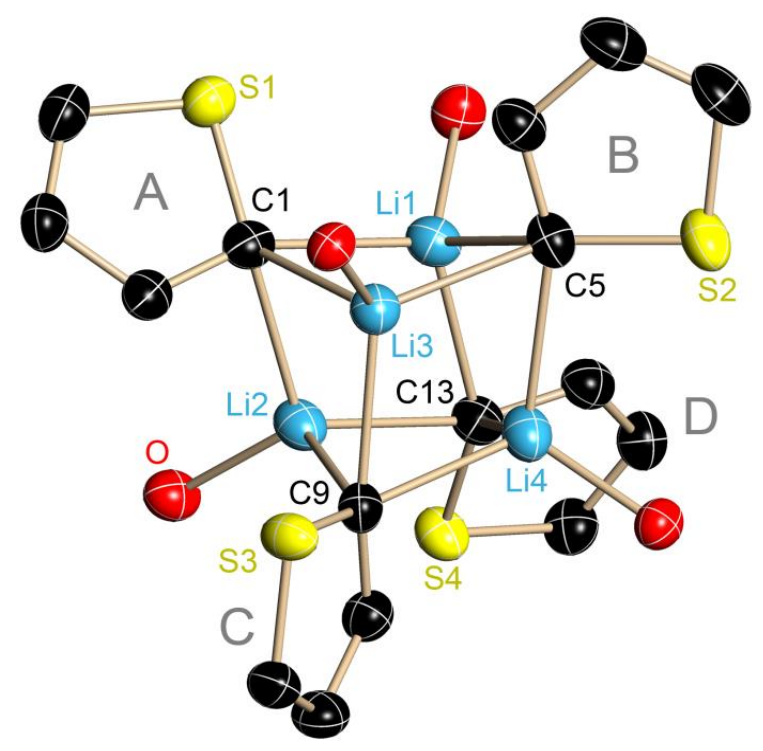

Figure 2-1. Molecular structure of $\left[\left(\mathrm{Et}_{2} \mathrm{O}\right) \mathrm{Li}\left(\mathrm{C}_{4} \mathrm{H}_{3} \mathrm{~S}\right)\right]_{4}(\mathbf{1})$. Anisotropic displacement parameters are depicted at the $50 \%$ probability level. Hydrogen atoms and oxygen bound ethyl groups are omitted for clarity. Note that the thienyl substituents are rotationally disordered relative to the $\mathrm{Li}_{3}$ plane, indicating no clear preference for additional $\mathrm{Li}$...S interactions. Selected bond lengths are displayed in Table 2-1.

Recent experimental charge density investigations ${ }^{[60]}$ showed that this structural motif is also present in $\left[(\mathrm{THF}) \mathrm{Li}_{2}\left\{\mathrm{H}_{2} \mathrm{CS}(\mathrm{N} t \mathrm{Bu})_{2}\right\}\right]_{2} \cdot{ }^{[61]} \mathrm{Up}$ to now the bonding mode and the forces that keep the highly charged $\mathrm{Li}^{+}$cations together are not fully understood. It is still controversially discussed to what extent the $\mathrm{Li}-\mathrm{C}$ contacts are to be considered as mainly ionic or show appreciable covalent contributions. ${ }^{[62]}$ On the basis of the 
experimental charge density distribution the interaction of the carbanion with the $\mathrm{Li}_{3}$ triangle was determined to be a $4 \mathrm{c}-2 \mathrm{e}$ bond. The carbon atom forms a bond path to each of the three lithium atoms. The valence shell charge concentration in the non-bonding region of the carbanion, representing the lone-pair, is inclined away from the centre of the $\mathrm{Li}_{3}$ triangle towards the lithium atom at the tip of the isosceles triangle. However, no bond critical points and thus no direct bonding interactions between the lithium atoms could be determined. ${ }^{[61]}$ Due to this predominantly ionic interaction it can rightly be assumed that the aggregation found in the solid state is lowered in solution, preferentially in polar donating solvents. This makes NMR studies from solution particularly important (see Chapter 2.1.4).

\subsubsection{Dimeric Structures of $\left[(\mathrm{THF})_{2} \mathrm{Li}\left(\mathrm{C}_{4} \mathrm{H}_{3} \mathrm{~S}\right)\right]_{2}$ $\left[(\mathrm{DME}) \mathrm{Li}\left(\mathrm{C}_{4} \mathrm{H}_{3} \mathrm{~S}\right)\right]_{2}(3)$ and $\left[(\mathrm{TMEDA}) \mathrm{Li}\left(\mathrm{C}_{4} \mathrm{H}_{3} \mathrm{~S}\right)\right]_{2}(4)$}

Because of its higher dipole moment and less steric demand THF shows better donor properties than diethyl ether towards the lithium atom in lithium organics $(1.75 \mathrm{D}$ for THF vs. $1.15 \mathrm{D}$ for $\left.\mathrm{Et}_{2} \mathrm{O}\right) .{ }^{[63]}$ Earlier deaggregation studies have shown that the aggregation of lithium organics is usually lowered by adding either steric demand or higher dipole moments. In addition, it was recently shown that THF can consecutively replace diethyl ether from the coordination of dimeric anthracenyllithium to give $\left[(\mathrm{THF})_{\mathrm{n}}\left(\mathrm{Et}_{2} \mathrm{O}\right)_{\mathrm{m}}\left\{\mathrm{Li}\left(\mathrm{C}_{14} \mathrm{H}_{8}\right) \mathrm{R}\right\}_{2}\right]$ dimers, with $\mathrm{n}+\mathrm{m}=3$ or $4 .{ }^{[64]}$ Consequently, the addition of THF to a diethyl ether solution of 1 gives crystals of the dimer [(THF) $\left.)_{2} \mathrm{Li}\left(\mathrm{C}_{4} \mathrm{H}_{3} \mathrm{~S}\right)\right]_{2}$ (2) (Figure 2-2, left). During my diploma thesis ${ }^{[65]}$ an XRD-experiment was conducted and the structural motif for $\mathbf{2}$ was determined. After recrystallization additional NMRstudies were performed during this thesis. The structure was verified by an X-ray experiment, confirming the same cell parameters.

Like observed in many dimers the metallated $\mathrm{C}_{\alpha^{-}}$and lithium atoms form a planar four-membered $\mathrm{Li}_{2} \mathrm{C}_{2}$ ring. This ring shows alternating shorter (av. $2.174 \AA$ ) and longer Li-C bonds (av. $2.283 \AA$ ), with the shorter bond length occurring at the lithium atom which is closer to the $\mathrm{SC}_{4} \mathrm{H}_{3}$-ring plane (Li1: $1.11 \AA$ from plane A compared to $1.56 \AA$ from plane B) and vice versa (Li2: $1.32 \AA$ from plane A compared to $0.85 \AA$ from plane B). This can be explained by predominant $\sigma$-bonding to the in-plane lone-pair. ${ }^{[64,66]}$ 


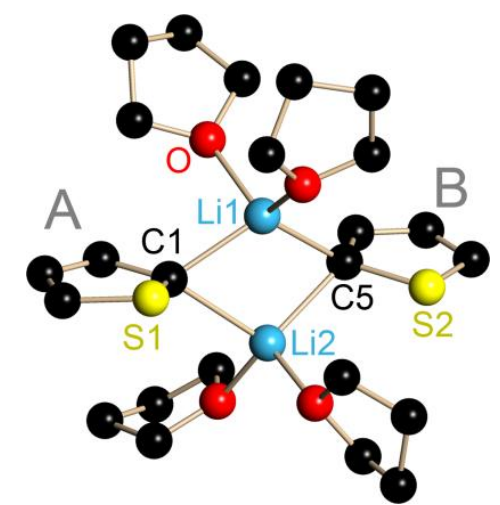

2

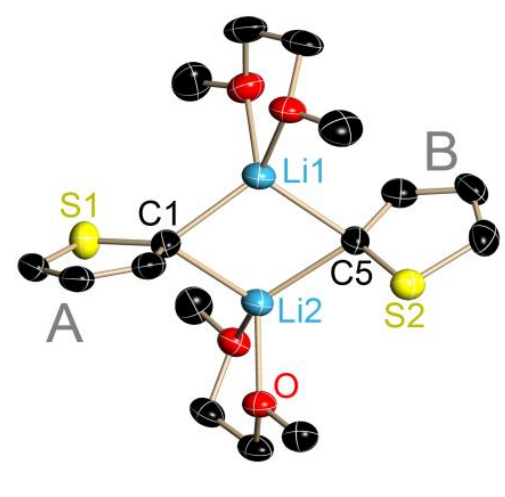

3

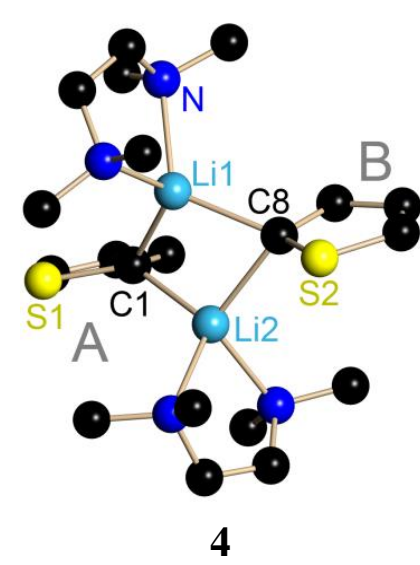

Figure 2-2. Molecular structures of $\left[(\mathrm{THF})_{2} \mathrm{Li}\left(\mathrm{C}_{4} \mathrm{H}_{3} \mathrm{~S}\right)\right]_{2}(\mathbf{2})^{[65]},\left[(\mathrm{DME}) \mathrm{Li}\left(\mathrm{C}_{4} \mathrm{H}_{3} \mathrm{~S}\right)\right]_{2}(\mathbf{3})$ and [(TMEDA) $\left.\mathrm{Li}\left(\mathrm{C}_{4} \mathrm{H}_{3} \mathrm{~S}\right)\right]_{2}(\mathbf{4})^{[52]}$. Anisotropic displacement parameters for $\mathbf{2}$ and $\mathbf{3}$ are depicted at the $50 \%$ probability level. Hydrogen atoms are omitted for clarity. Note that the thienyl substituents are rotationally disordered relative to the $\mathrm{Li} \cdots \mathrm{Li}$ vector, indicating no clear preference for additional $\mathrm{Li} \cdots \mathrm{S}$ interactions. Selected bond lengths are displayed in Table 2-1.

The structure of $\mathbf{3}$ has been reported in my diploma thesis. ${ }^{[65]}$ Within the XRD experiments to confirm the reported structure of freshly grown crystals of $\mathbf{3}$ and a new polymorph of 3 was determined. The structure of $\left[(T M E D A) L i\left(\mathrm{C}_{4} \mathrm{H}_{3} \mathrm{~S}\right)\right]_{2}$ (4) (Figure 2-2, right) was determined by Spek and Smeets earlier. ${ }^{[52]}$ Switching the DME donor base in $\left[(\mathrm{DME}) \mathrm{Li}\left(\mathrm{C}_{4} \mathrm{H}_{3} \mathrm{~S}\right)\right]_{2}(3)$ (center) to TMEDA in $\mathbf{4}$ has virtually no impact on the structural parameters. The shorter $\mathrm{Li}-\mathrm{C}$ bonds in the four-membered ring are $2.147 \AA$ and the longer ones are $2.228 \AA$. The same is valid for the $\sigma / \pi$-bonding. The distances of the lithium atoms to the thienyl ring plane are: Li1: $1.30 \AA$ from plane A compared to $0.92 \AA$ from plane B and vice versa Li2: $1.26 \AA$ from plane A compared to $1.59 \AA$ from plane B.

Table 2-1. Selected bond lengths [̊̊] in the solid-state structures of $\mathbf{1}$ to $\mathbf{5}$.

\begin{tabular}{lllll}
\hline & av. $\mathbf{L i} \cdots \mathbf{L i}$ & av. $\mathbf{L i}-\mathbf{C}_{\boldsymbol{a}}$ & $\mathbf{L i}-\mathbf{O}, \boldsymbol{N}$ & Ref \\
\hline $\mathbf{1}$ & $2.714(5)$ & $2.282(4)$ & $1.975(7)$ & \\
$\mathbf{2}$ & $2.487(3)$ & $2.228(4)$ & $1.979(6)$ & diploma $^{[65]}$ \\
$\mathbf{3}$ & $2.504(4)$ & $2.212(14)$ & $2.002(3)$ & \\
$\mathbf{4}$ & 2.581 & 2.187 & 2.164 & ${ }^{[52]}$ \\
$\mathbf{5}$ & - & $2.115(3)$ & $2.134(2)$ & diploma $^{[65]}$ \\
\hline
\end{tabular}

Selected bond lengths of $\mathbf{1 - 5}$ were summarized in Table 2-1. A shortening of the $\mathrm{Li}-$ $\mathrm{C}$ bonds could be observed from the tetramer (1) via the dimers (2-4) to the monomer (5). 


\subsection{3 [(PMDETA $\left.) \operatorname{Li}\left(\mathrm{C}_{4} \mathrm{H}_{3} \mathrm{~S}\right)\right](5)$}

In order to investigate the coordination pattern of $\left[(\operatorname{PMDETA}) \mathrm{Li}\left(\mathrm{C}_{4} \mathrm{H}_{3} \mathrm{~S}\right)\right]$ (5) in solution by means of NMR experiments, new crystals of previously published $\mathbf{5}^{[65]}$ were synthesized. As well as for $\mathbf{2}$ the structure of $\mathbf{5}$ was verified by XRD experiments as the starting point for the NMR investigations elucidated in the next chapter.

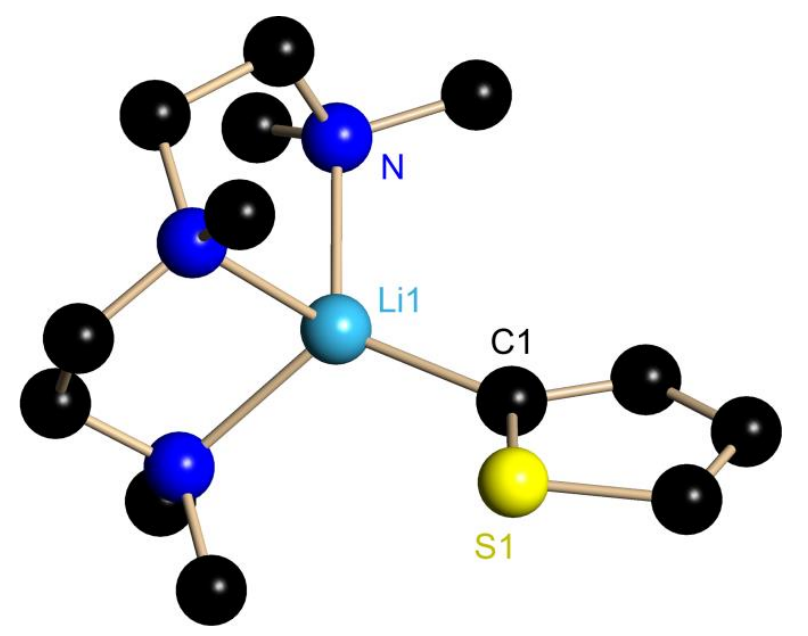

Figure 2-3. Molecular structure of [(PMDETA) $\left.\mathrm{Li}\left(\mathrm{C}_{4} \mathrm{H}_{3} \mathrm{~S}\right)\right](5) .{ }^{[65]}$

Providing more than two donor atoms in one donor base changes the aggregation state to a monomer. In $\left[(\mathrm{PMDETA}) \mathrm{Li}\left(\mathrm{C}_{4} \mathrm{H}_{3} \mathrm{~S}\right)\right](\mathbf{5})$ the lithium atom is coordinated to the single $\mathrm{C}_{\alpha}$-atom in the ring plane like in other lithium aryl monomers (see Figure $2-3) .{ }^{[6,67]}$ It is displaced only $0.38 \AA$ from the idealized thienyl plane, and therefore bonded exclusively to the in-plane lone pair. The Li-C distance of $2.115(3) \AA$ is the shortest in the presented series of 2-thienyllithium structures. Hence, the presented structures mirror a trend already observed in a homologous series of other lithium organics: the lower the aggregation is, the lower is the number of $\mathrm{Li}-\mathrm{C}$ contacts, and the shorter are the remaining contacts (Table 2-1). The mainly ionic metal cation-carbanion attraction is concentrated on one recipient. In the series $[\mathrm{PhLi}]_{\infty},{ }^{[3]}\left[\left(\mathrm{Et}_{2} \mathrm{O}\right) \mathrm{LiPh}\right]_{4},{ }^{[68]}$ $[(\mathrm{TMEDA}) \mathrm{LiPh}]_{2},{ }^{[5]}$ and $[(\mathrm{PMDETA}) \mathrm{LiPh}]^{[6]}$ the $\mathrm{C}-\mathrm{Li}$ distances decrease from polymer $(2.32 / 2.24 \AA)>\operatorname{tetramer}(2.33 \AA)>\operatorname{dimer}(2.24 \AA)>\operatorname{monomer}(2.14 \AA)$. The $\mathrm{Li}-\mathrm{C}$ distance of the donor-free polymer compared to those of the donor base coordinated tetramer increases because the charge density supply of the donor base leaves the lithium cation less attractive to the carbanion in the tetramer. The trend is not 
limited to lithium aryls but is also obviously going from $[t \mathrm{BuLi}]_{4}{ }^{[7]}(2.25 \AA)$ via $\left[\left(\mathrm{Et}_{2} \mathrm{O}\right) \mathrm{Li} t \mathrm{Bu}\right]_{2}{ }^{[7]}(2.18 \AA)$ to $[\{(-) \text {-sparteine }\} \mathrm{Li} t \mathrm{Bu}]^{[69]}(2.11 \AA)$, respectively.

\subsubsection{Aggregation Study of 1 - 5 in Solution}

In his seminal case study on the relationships between solvation, aggregation and reactivity in lithium organic chemistry Collum stated $X$-ray crystallography provides little insight into the thermodynamics of aggregation and solvation. ${ }^{[70]}$ This is appropriate as the crystal structure is commonly believed to represent the least soluble derivative in the pot and not necessarily the most abundant, let alone the most reactive species. Moreover, the least populated species might represent the bottleneck in the equilibrium the whole reaction goes through on the course towards the overall product. This was elaborated in several studies on various lithium amides in numerous donating solvents by sophisticated NMR studies. ${ }^{[71]}$

At inert gas conditions in an argon glove box crystals of the aggregates 1-4 and the monomer 5 were dissolved in the non-donating solvent toluene- $d_{8}$ and transferred in NMR tubes tapped by septa before exposition to the experiment. Starting from the challenging, yet well-established solid-state structure any change in the aggregation would be detected during the NMR experiment. If no changes occur it would be possible to prove the aggregation of the solid state is retained the same in solution. ${ }^{[72]}$ Firstly, routine $1 \mathrm{D}\left({ }^{1} \mathrm{H},{ }^{13} \mathrm{C},{ }^{7} \mathrm{Li}\right) \mathrm{NMR}$ experiments were employed followed by sophisticated 2D techniques ( ${ }^{1} \mathrm{H}$-DOSY, $\left.{ }^{1} \mathrm{H},{ }^{7} \mathrm{Li}-\mathrm{HOESY}\right)$. Due to the low solubility, all NMR spectra of $\left[\left(\mathrm{Et}_{2} \mathrm{O}\right) \mathrm{Li}\left(\mathrm{C}_{4} \mathrm{H}_{3} \mathrm{~S}\right)\right]_{4}$ (1) and $\left[(\mathrm{TMEDA}) \mathrm{Li}\left(\mathrm{C}_{4} \mathrm{H}_{3} \mathrm{~S}\right)\right]_{2}$ (4) had to be measured with a small excess of the corresponding donor base. Toluene- $d_{8}$ was chosen as solvent as it cannot interfere with the coordination sphere of the lithiated thiophenes and the corresponding donor bases. 


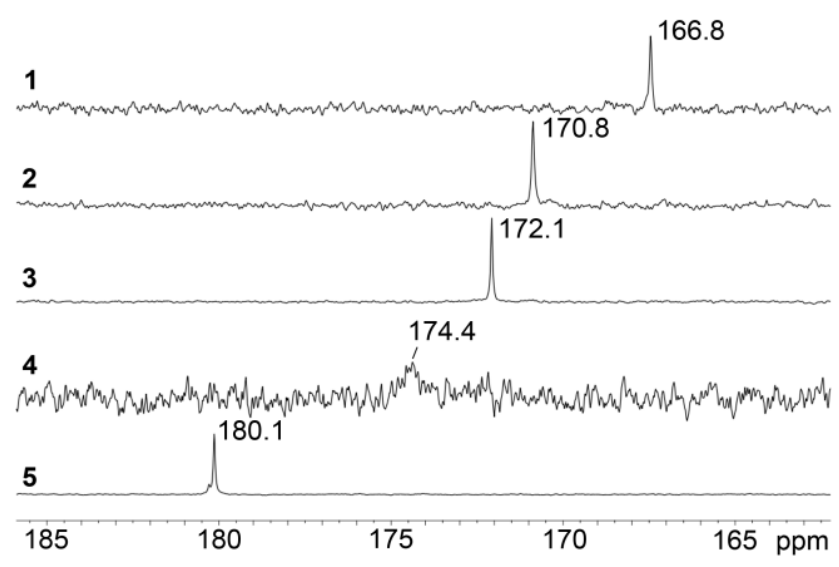

Figure 2-4. Partial ${ }^{13} \mathrm{C}\left\{{ }^{1} \mathrm{H}\right\}$ NMR spectra showing the $\mathrm{C}_{\alpha}$ signal of $\mathbf{1 - 5}$ in toluene- $d_{8}$ at room temperature. The poor resolution of the spectrum of $\mathbf{4}$ is caused by the low solubility in toluene- $d_{8}$.

In Figure 2-4 the $C_{\alpha}$ signals of 1-5 are shown. Down field shifting from the tetrameric $\mathbf{1}$ via the dimeric $\mathbf{2 - 4}$ to the monomeric species $\mathbf{5}$ is observed. The ${ }^{13} \mathrm{C}$ chemical shifts of the $\mathrm{C}_{\alpha}$-atom have been used as important indicator for organolithium aggregation before. ${ }^{[50,73]} \mathrm{An}$ increase of the ${ }^{13} \mathrm{C}$ chemical shift value from the tetramer 1 to the PMDETA-coordinated monomeric structure $\mathbf{5}$ is observed, thus confirming the coordination behaviour found by single crystal XRD-experiments. Furthermore, within the dimeric structures 2,3 and 4 , the ${ }^{13} \mathrm{C}$ chemical shifts show an intriguing correlation with the $\mathrm{Li}-\mathrm{C}_{\alpha}$-distances (Table 2-1). The references above use carbon chemical shifts and ${ }^{13} \mathrm{C}-{ }^{6} \mathrm{Li}$ coupling constants to distinguish between different aggregation states. Nevertheless, they have not scaled the observed ${ }^{13} \mathrm{C}$ chemical shifts to $\mathrm{C}_{\alpha}-\mathrm{Li}$ distances derived from XRD data, which turned out to be fairly significant for this series of 2thienyllithium aggregates, whereas, the corresponding ${ }^{1} \mathrm{H}$ and ${ }^{7} \mathrm{Li}$ chemical shifts were much less reliable and did not follow a clear trend (see Experimental Section).

Therefore the ${ }^{13} \mathrm{C}$ NMR spectra indicate the aggregation of 2-thienyl in non-donating toluene- $d_{8}$. However, the aggregation cannot be confirmed by mononuclear NMR spectra only. Fast exchange processes in solution, e.g. equilibria between different aggregates may hamper the identification and necessitate further (2D) NMR experiments.

Due to the high solubility, $\mathbf{3}$ was chosen for a variable temperature NMR study. 


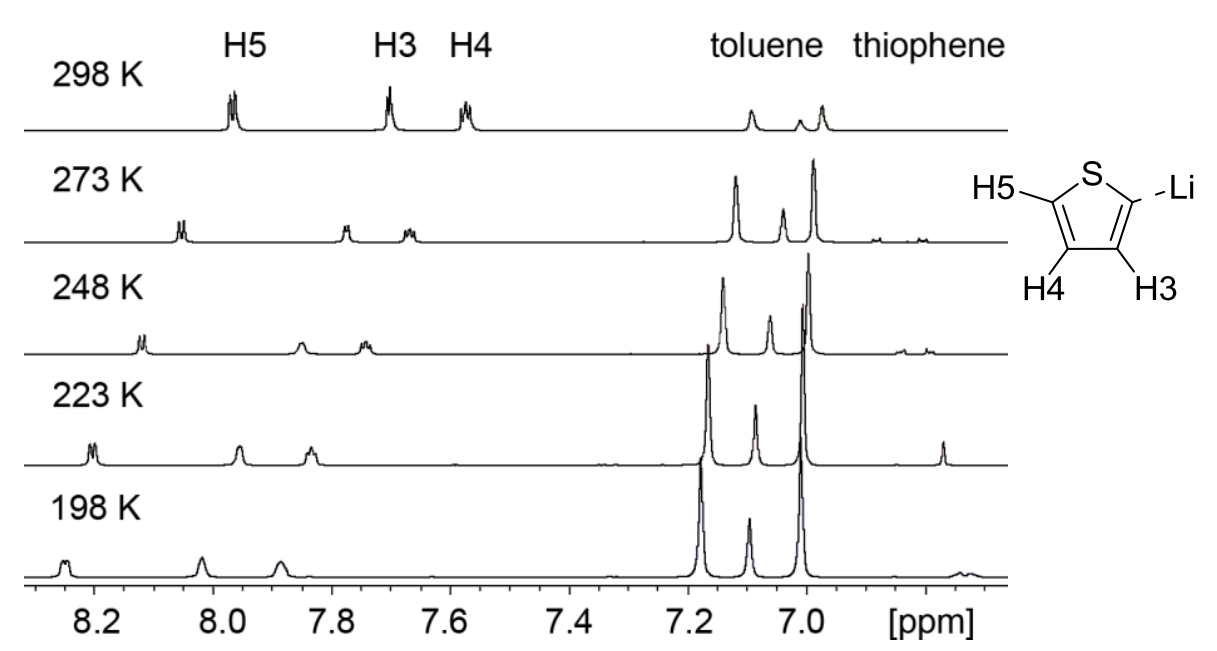

Scheme 2-2. Partial variable temperature ${ }^{1} \mathrm{H}$ NMR spectra of 3 in toluene- $d_{8}$ from $298 \mathrm{~K}$ (top) to $198 \mathrm{~K}$ (bottom).

While slowly cooling down a sample of $\mathbf{3}$ in toluene- $d_{8}$ to $198 \mathrm{~K}$ it can be noticed that the aromatic signals drift to lower field. This observation can be explained by the temperature dependency of the resonance frequency of every proton. ${ }^{[74]}$

Over the whole temperature range, only one set of signals is identified (Scheme 2-2). This is consistent with the ${ }^{13} \mathrm{C}\left\{{ }^{1} \mathrm{H}\right\}$ NMR spectra in Figure 2-4. A dynamic equilibrium between the monomer and dimer would lead to two sets of signals at low temperature. Cooling down near to the freezing point of toluene- $d_{8}(188 \mathrm{~K})$ only one set of resonances can be observed.

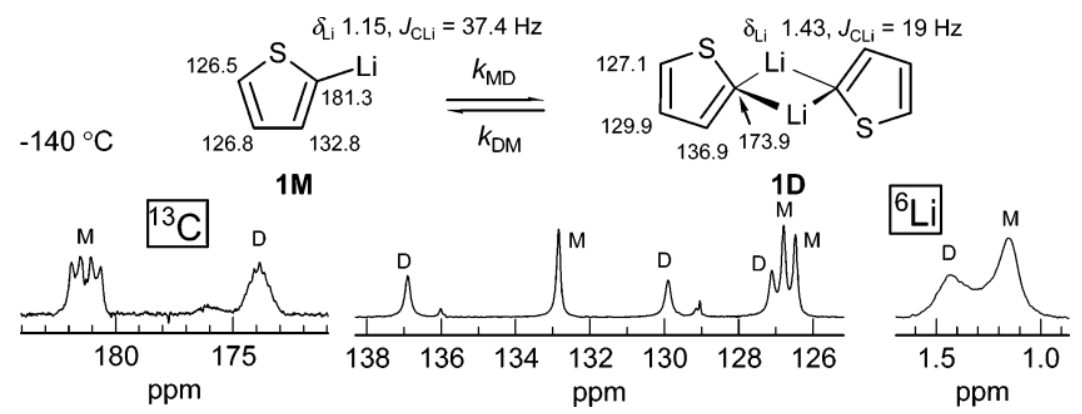

Scheme 2-3. Partial ${ }^{13} \mathrm{C}$ and ${ }^{6} \mathrm{Li}$ NMR spectra of $0.3 \mathrm{M}$ 2-thienyllithium in THF: $\mathrm{Me}_{2} \mathrm{O}: \mathrm{Et}_{2} \mathrm{O}(3: 2: 1)(\mathrm{D}=$ dimer, $\mathrm{M}=$ monomer) at $133 \mathrm{~K} \cdot{ }^{[50 \mathrm{~b}]}$

This result is contrary to the NMR studies of Reich et al. on 2-thienyllithium in a mixture of THF : $\mathrm{Me}_{2} \mathrm{O}: \mathrm{Et}_{2} \mathrm{O}(3: 2: 1)$ in which a dimer - monomer equilibrium can be seen at $133 \mathrm{~K}$ (Scheme 2-3). ${ }^{[50 \mathrm{~b}]}$ Obviously the ethereal solution is responsible for the 
change of aggregation at lower temperature. In the non-donating solvent toluene the dimeric structure of $\mathbf{3}$ is retained.

While ${ }^{1} \mathrm{H},{ }^{13} \mathrm{C}$ and ${ }^{7} \mathrm{Li}$ NMR spectroscopy can only indicate the aggregation of a series of lithium organics in solution, the sophisticated diffusion ordered spectroscopy (DOSY) can estimate the molecular size and aggregation as well as dynamic behavior of lithium organics. ${ }^{[75]}$ Therefore we decided to conduct 2D NMR experiments (e.g. DOSY and HOESY) of 1-5 in the non-donating solvent toluene- $d_{8}$.

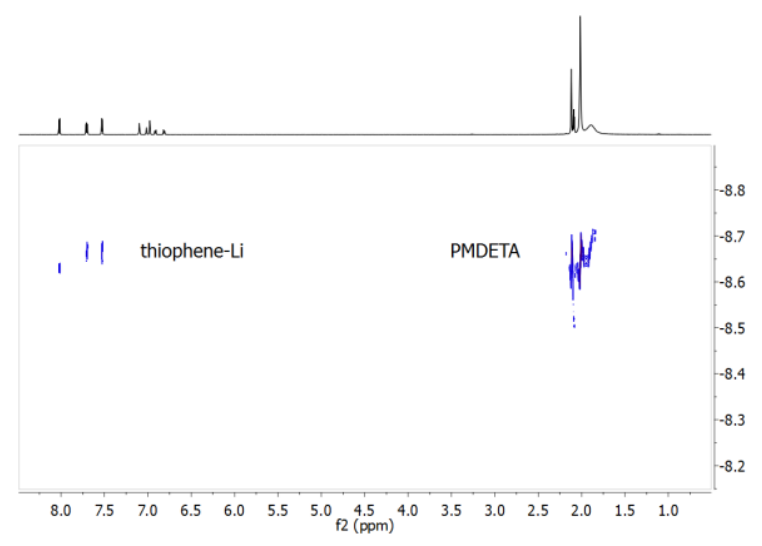

Figure 2-5. ${ }^{1} \mathrm{H}$-DOSY spectrum of $\mathbf{5}^{[56]} \mathrm{X}$-axis: ${ }^{1} \mathrm{H}$ spectrum, y-axis: diffusion coefficient $\left[{ }^{*} 10^{-9} \mathrm{~m}^{2} / \mathrm{s}\right]$.

If 2-thienyllithium and the donor base form a stable complex protons of both units should display the same diffusion coefficient. Nevertheless, the spectra were difficult to interpret due to excess of solvent or exchange processes (exemplary spectrum of $\mathbf{5}$ is shown in Figure 2-5). Furthermore in the spectrum of 2 the diffusion coefficient of the donor molecules varies significantly from that of the lithiated thiophene. This indicates that in solution THF molecules partially dissociate from the lithiated thiophene structure possibly leaving $\mathrm{Li}$ atoms threefold-coordinated. In principle, higher thiophene aggregation would also set free THF molecules - in fact, a dimer-tetramer equilibrium is known to exist for $n$-BuLi in THF solution. ${ }^{[76]}$ This cannot be finally proven by the reached low temperatures $(193 \mathrm{~K})$ but would be in disagreement with the chemical shifts shown in Figure 2-4.

The aggregation of 1-5 was also investigated using the ${ }^{1} \mathrm{H},{ }^{7} \mathrm{Li}$ heteronuclear Overhauser effect (HOE). Since the crystal structures contain several short proton-lithium distances (up to $4 \AA$ ), cross-peaks should appear in ${ }^{1} \mathrm{H},{ }^{7} \mathrm{Li}-\mathrm{HOESY}$ spectra that either prove or disprove the solid-state structure in solution. ${ }^{[77]}$ 


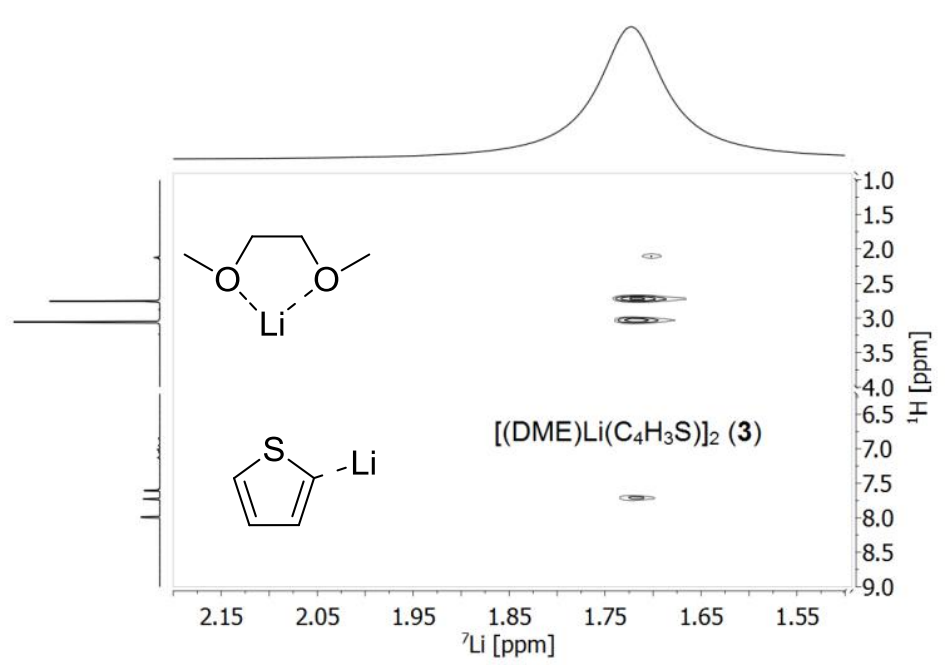

Figure 2-6. ${ }^{1} \mathrm{H},{ }^{7}$ Li-HOESY spectrum of $3{ }^{[56]}$

An exemplary ${ }^{1} \mathrm{H},{ }^{7} \mathrm{Li}-\mathrm{HOESY}$ spectrum of 3 is shown in Figure 2-6. The ${ }^{7} \mathrm{Li}$ spectrum of 3 is plotted on the abscissa, the ${ }^{1} \mathrm{H}$ NMR spectrum on the ordinate. Crosspeaks are shown between the lithium and the protons of DME and H3 of the thienyl moiety, respectively.

It could be concluded that the solid-state aggregation of 3-5 is retained upon solvation in toluene- $d_{8}$. Due to the low solubility of $\mathbf{1}$ cross peaks could be observed, but they were not sufficiently strong for really short mixing times, preventing them to be included in this comparison.

Within this NMR study we found out that the TMEDA and PMDETA coordinated species 4 and 5 show a higher reactivity compared to 1-3. These two compounds were able to lithiate toluene- $d_{8}$ at room temperature. ${ }^{[56]}$ The lithiated intermediate has not been observed in the ${ }^{1} \mathrm{H}$ NMR, due to the fast re-metallation of thiophene. The $\mathrm{H}-2 / \mathrm{H}-5$ protons of thiophene are significantly more acidic $\left(\mathrm{pK}_{\mathrm{a}} \sim 33\right)$ compared to the methyl protons of toluene $\left(\mathrm{pK}_{\mathrm{a}} \sim 40\right)^{[78]}$, leading to the fast $\mathrm{Li} / \mathrm{H}$ exchange at the lithiated methyl group of toluene. Typically, the lithiation of toluene is carried out under rather harsh conditions ( $n$-BuLi / TMEDA and high temperatures) and ring (poly)metallation occurs as a side reaction. ${ }^{[79]}$ Already mentioned in the introduction milder conditions for the lithiation of toluene were reported, recently. ${ }^{[15]}$ 


\subsection{Aggregation of Methyl-substituted 2-Thienyllithium}

\subsection{1 $\left[(\mathrm{THF})_{2} \mathrm{Li}\left\{\left(\mathrm{C}_{4} \mathrm{H}_{2} \mathrm{~S}\right)-5-\mathrm{Me}\right\}\right]_{2}(6),\left[(\mathrm{DME}) \mathrm{Li}\left\{\left(\mathrm{C}_{4} \mathrm{H}_{2} \mathrm{~S}\right)-5-\mathrm{Me}\right\}\right]_{2}$ (7) and [(TMEDA $\left.) \mathrm{Li}\left\{\left(\mathrm{C}_{4} \mathrm{H}_{2} \mathrm{~S}\right)-4-\mathrm{Me}\right\}\right]_{2}(8)$}

Based on the knowledge of the aggregation study of 2-thienyllithium in which the addition of THF, DME or TMEDA to the tetrameric structure of $\mathbf{1}$ led to the dimers 2-4, and the addition of PMDETA to the monomer $\mathbf{5}$ another aim was to further study the aggregation states of methylated 2-thienyllithium, particularly 5-methyl-2-thienyllithium and 4-methyl-2-thienyllithium. Only one solid-state structure of 5-methyl-2thienyllithium, the tetrameric structure of $\left[\left(\mathrm{Et}_{2} \mathrm{O}\right) \mathrm{Li}\left\{\left(\mathrm{C}_{4} \mathrm{H}_{2} \mathrm{~S}\right)-5-\mathrm{Me}\right\}\right]_{4},{ }^{[49]}$ has been characterized by single crystal X-ray diffraction experiments. A similar approach as in the case of 2-thienyllithium was chosen to deaggregate the tetramer in diethyl ether to obtain smaller aggregates. Again, the donor bases THF, DME and TMEDA were selected and the dimeric structures of $\left[(\mathrm{THF})_{2} \mathrm{Li}\left\{\left(\mathrm{C}_{4} \mathrm{H}_{2} \mathrm{~S}\right)-5-\mathrm{Me}\right\}\right]_{2}$ (6), $\left[(\mathrm{DME}) \mathrm{Li}\left\{\left(\mathrm{C}_{4} \mathrm{H}_{2} \mathrm{~S}\right)-5-\mathrm{Me}\right\}\right]_{2}$ (7) and $\left[(\mathrm{TMEDA}) \mathrm{Li}\left\{\left(\mathrm{C}_{4} \mathrm{H}_{2} \mathrm{~S}\right)-4-\mathrm{Me}\right\}\right]_{2}$ (8) could be determined (Figure 2-7). Selected bond lengths of 6-8 are summarized in Table 2-2. The structural elucidation of 7 was carried out during my diploma thesis. ${ }^{[65]}$ New crystals have been obtained since then and the cell parameters of the crystal have been validated by XRD experiments and further analysis of its structure in solution was applied by NMR experiments. No new crystals of 5-methyl-2-thienyllithium - TMEDA could be obtained, but lithiated 3-methylthiophene yielded suitable crystals of $\mathbf{8}$ for structural analysis.
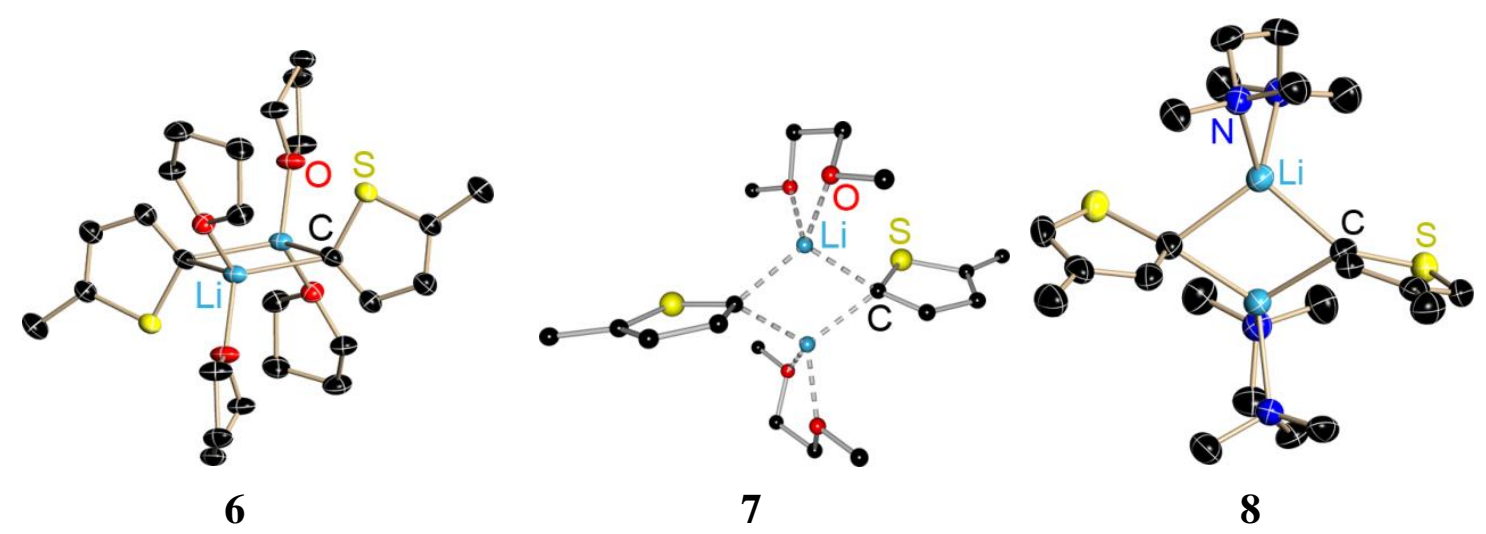

Figure 2-7. Molecular structure of 6, $7^{[65]}$ and 8 . Anisotropic displacement parameters of $\mathbf{6}$ and $\mathbf{8}$ are depicted at the $50 \%$ probability level. Hydrogen atoms are omitted for clarity. The positional disorder in $\mathbf{8}$ is explained, vide infra. 
In accordance with the structural motif that is common between $\mathbf{2}-\mathbf{4}$, the dimers 6 8 form a $\mathrm{C}_{2} \mathrm{Li}_{2}$ four-membered ring. The THF coordinated dimer 6 crystallizes in the triclinic space group $P \overline{1}$ with half a dimer in the asymmetric unit. The lithium atoms in 6 are coordinated by two THF molecules and the $C_{\alpha}$ atoms of the 5-methyl-2-thienyl molecules. The distances in the $\mathrm{C}_{2} \mathrm{Li}_{2}$ four-membered ring are almost equidistant $(\mathrm{Li}-\mathrm{C}$ 2.241(7) $\AA$ and 2.244(7) $\AA$ ). The structure of 7 showed two slightly shorter C-Li bond lengths $(\mathrm{Li}-\mathrm{C} 2.171(4) \AA \text { and 2.210(6) } \AA)^{[65]}$ compared to 6 .

Due to the methyl group in the 3- instead of the 5-position, it is likely that the lithiation of 3-methylthiophene lead to two products, i.e. 4-methyl-2-thienyllithium and 3-methyl-2-thienyllithium (Scheme 2-4).

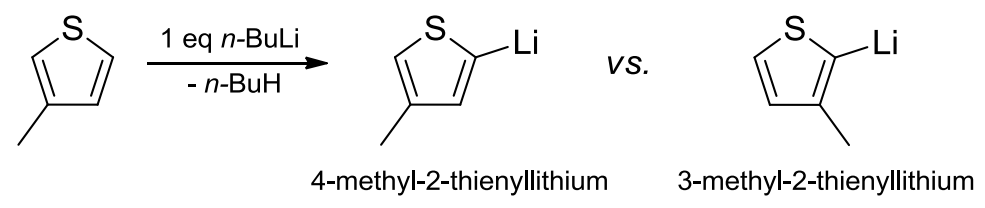

Scheme 2-4. Lithiation of 3-methylthiophene.

The crystal structure of 8 reveals this 2- vs. 5-metallation (Figure 2-8). The $\mathrm{C}_{2} \mathrm{Li}_{2}$ four-membered ring in $\mathbf{8}$ shows alternating shorter (av. 2.175(18) $\AA$ ) and longer Li-C bonds (av. 2.323(12) $\AA$ ), similar to [(TMEDA) $\left.\mathrm{Li}\left(\mathrm{C}_{4} \mathrm{H}_{3} \mathrm{~S}\right)\right]_{2}$ (4).

Analogous to the positional disorder in $\mathbf{1 - 5}$, a $180^{\circ}$ rotation along the $\mathrm{C}-\mathrm{Li}$ bond occurs and four positions of the lithiated thienyl moiety could be. The main domain shows the 4-methyl-2-thienyl moiety (A, Figure 2-8 top-left; SOF: 0.85); the moderately occupied domain displays the 3-methyl-2-thienyl pendant (D, bottom-right; SOF: 0.08). The minor positions are occupied by positional disordered moieties of 4methyl-2-thienyllithium and 3-methyl-2-thienyllihtium (B, top-right; SOF: 0.03 and $\mathbf{C}$, bottom-left; SOF: 0.04). 


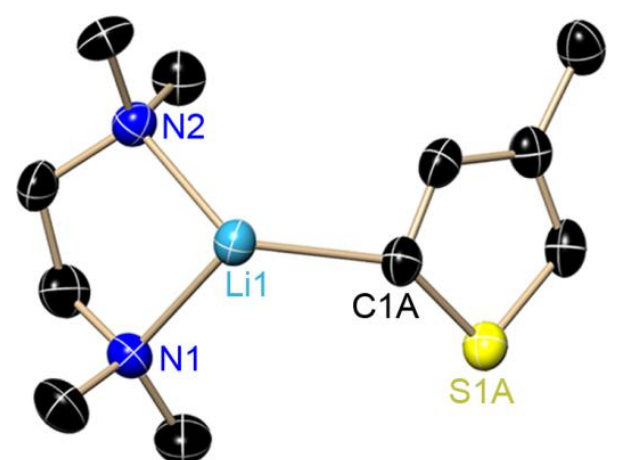

A

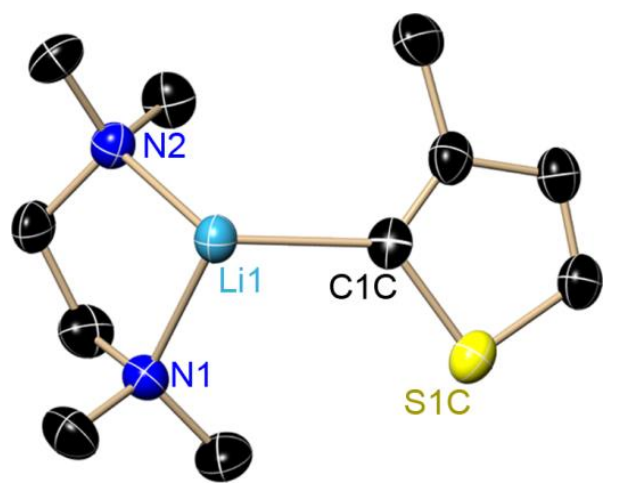

C

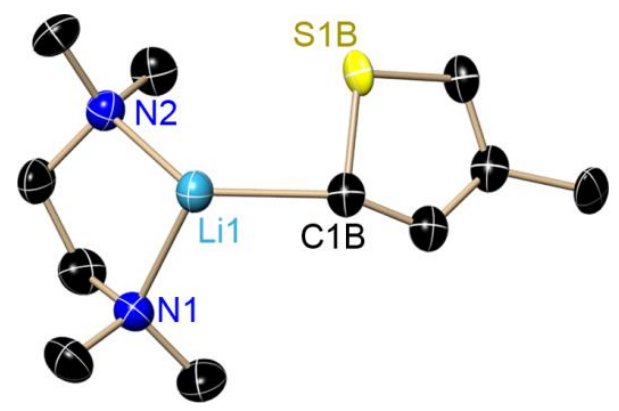

B

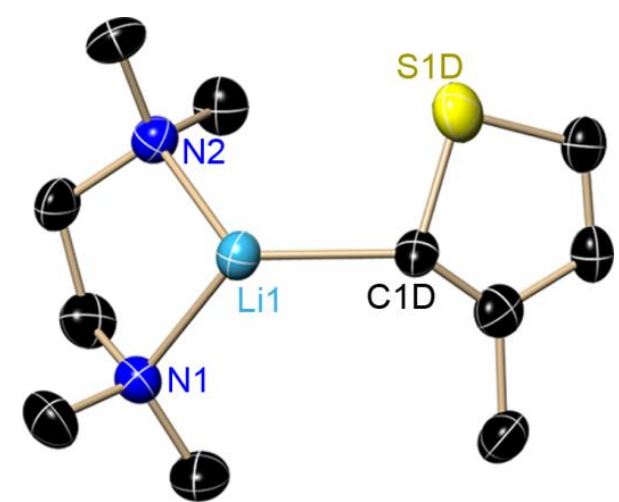

D

Figure 2-8. 2 vs. 5 lithiation of 3-methylthiophene ( $\mathbf{A}=4$-methyl-2-thienyl, SOF: 0.85; $\mathbf{B}=4$-methyl-2thienyl, SOF: 0.03; C= 3-methyl-2-thienyl, SOF: 0.04; D = 3-methyl-2-thienyl, SOF: 0.08).

The addition of the tridentate $N$-donor base PMDETA led to the monomeric structure of 5-methyl-2-thienyllithium in the solid state, similar to 2-thienyllithium. The structure of the monomer [(PMDETA)Li $\left.\left\{\left(\mathrm{C}_{4} \mathrm{H}_{2} \mathrm{~S}\right)-5-\mathrm{Me}\right\}\right]$ is shown in Figure 2-9 and selected bond lengths are summarized in Table 2-2. NMR spectra of crystals dissolved in benzene- $d_{6}$ were already measured during my diploma thesis (Table 2-3 bottom). ${ }^{[65]}$

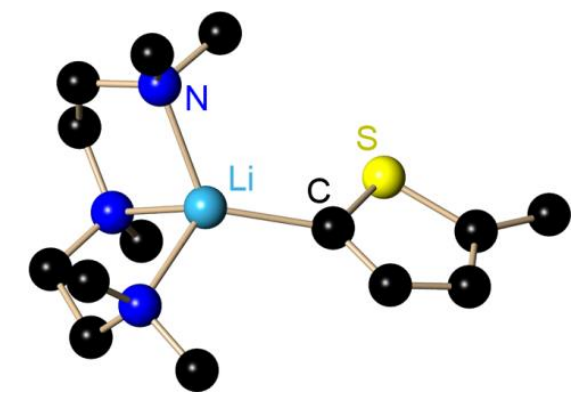

Figure 2-9. Molecular structure of [(PMDETA) $\left.\mathrm{Li}\left\{\left(\mathrm{C}_{4} \mathrm{H}_{2} \mathrm{~S}\right)-5-\mathrm{Me}\right\}\right] .{ }^{[65]}$

The PMDETA chelated monomer showed the shortest $\mathrm{Li}-\mathrm{C}$ bond length as well as largest low field shift in the ${ }^{13} \mathrm{C}$ NMR spectrum in the series of 6-8. Similar to the trend 
of the Li-C distances in the aggregates of 2-thienyllithium (1-5) a bond shortening from the tetramer to the monomer could be observed in methyl-substituted 2-thienyllithium (Table 2-2) indicating again a correlation between the aggregate and bond length.

Table 2-2. Selected bond lengths $[\AA]$ in the single crystal of $\mathbf{6}$ to $\mathbf{8}$ and known tetramer and monomer.

\begin{tabular}{cllll}
\hline & av. Li $\cdots \mathbf{L i}$ & av. $\mathbf{L i}-\mathbf{C}_{\boldsymbol{a}}$ & $\mathbf{L i}-\mathbf{O}, \boldsymbol{N}$ & Ref \\
\hline tetramer & $2.72(2)$ & $2.270(14)$ & $2.024(13)$ & {$[49]$} \\
$\mathbf{6}$ & $2.496(11)$ & $2.242(7)$ & $1.959(6)$ & \\
$\mathbf{7}$ & $2.488(5)$ & $2.190(5)$ & $2.007(4)$ & {$[65]$} \\
$\mathbf{8}$ & $2.566(10)$ & $2.193(6)$ & $2.153(13)$ & \\
monomer & - & $2.109(3)$ & $2.137(3)$ & {$[65]$} \\
\hline
\end{tabular}

\subsubsection{Aggregation Study of 6 - 8 in Solution}

Dissolving the crystals of $\mathbf{6 - 8}$ in the non-donating solvent toluene- $d_{8}$ leads to the NMR resonances summarized in Table 2-3. Crystals of the PMDETA coordinated monomer [(PMDETA)Li $\left.\left\{\left(\mathrm{C}_{4} \mathrm{H}_{2} \mathrm{~S}\right)-5-\mathrm{Me}\right\}\right]$ were dissolved in benzene- $d_{6}$ and the ${ }^{1} \mathrm{H}$ and ${ }^{13} \mathrm{C}$ NMR spectra were recorded. Taking into account that the resonances in toluene and benzene are similar, an analogue trend in the signals of methyl-substituted 2thienyllithium compounds can be observed as for 2-thienyllithium. 7 shows a high solubility in toluene- $d_{8}$ similar to that of $\mathbf{3}$ and was chosen for multiple temperature ${ }^{1} \mathrm{H}$ NMR experiments.

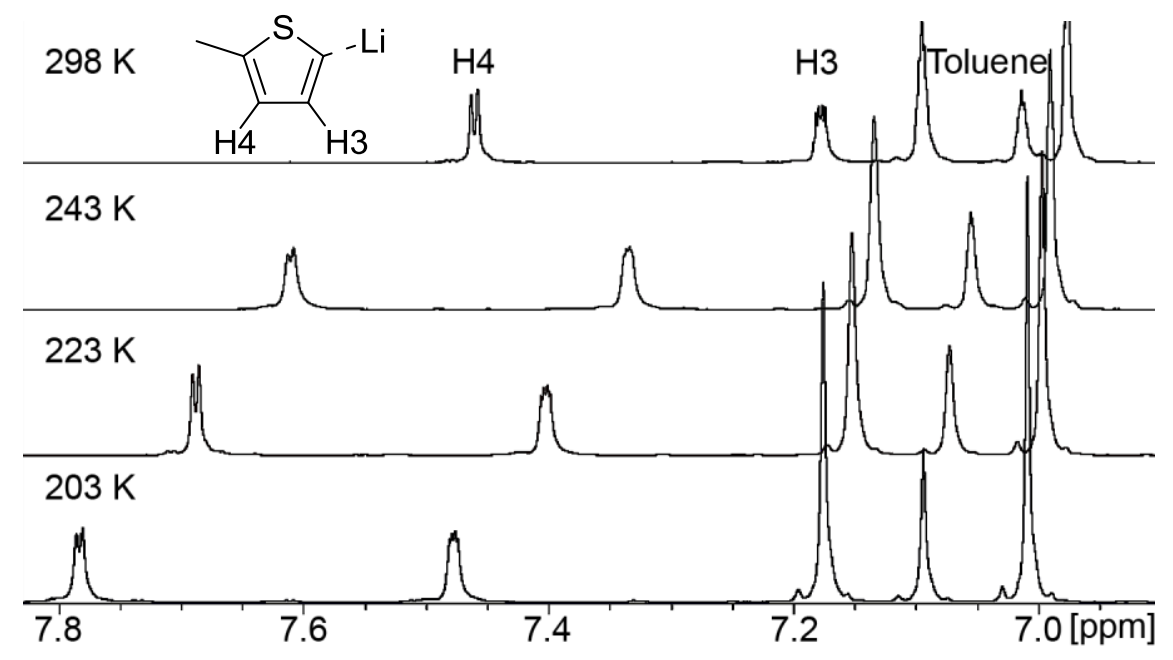

Scheme 2-5. Low temperature ${ }^{1} \mathrm{H}$ NMR spectra of $\left[(\mathrm{DME}) \mathrm{Li}\left\{\left(\mathrm{C}_{4} \mathrm{H}_{2} \mathrm{~S}\right)-5-\mathrm{Me}\right\}\right]_{2}(7)$. 
While slowly cooling down a sample of 7 in toluene- $d_{8}$ to $198 \mathrm{~K}$ it can be noticed that the entire set of signals drifts to lower field. As mentioned before, this observation follows the temperature dependence of the resonance frequency of every proton.

At room temperature, only one set of signals can be identified (Scheme 2-5 top). This is consistent with the spectra of 3 shown in Figure 2-4. A dynamic equilibrium between the monomer and dimer would lead to two sets of signals at low temperature. Nevertheless, cooling down near to the freezing point of toluene- $d_{8}(188 \mathrm{~K})$, only one set of resonances can be observed.

A summary of the ${ }^{1} \mathrm{H}$ NMR and ${ }^{13} \mathrm{C}$ NMR shifts as well as the Li-C distances in the structures of 6-8 and the literature-known aggregates are listed in Table 2-3.

Table 2-3. Selected bond lengths $[\AA]$ in the solid-state structures and selected ${ }^{1} \mathrm{H}$ and ${ }^{13} \mathrm{C}$ NMR signals of methyl-substituted 2-thienyllithium derivatives.

\begin{tabular}{|c|c|c|c|c|}
\hline & $\delta(\mathbf{H 3})$ & $\delta\left(\mathbf{C}_{\alpha}\right)$ & av. $\mathrm{Li}-\mathrm{C}_{\boldsymbol{a}}$ & Ref \\
\hline$\left[\left(\mathbf{E t}_{2} \mathrm{O}\right) \mathrm{Li}\left\{\left(\mathrm{C}_{4} \mathbf{H}_{2} \mathbf{S}\right)-5-\mathrm{Me}\right\}\right]_{4}$ & - & - & $2.270(14)$ & [49] \\
\hline 6 & $-^{a)}$ & - ${ }^{a)}$ & $2.242(7)$ & \\
\hline 7 & 7.46 & 172.2 & $2.190(5)^{[65]}$ & \\
\hline 8 & 7.98 & 176.7 & $2.193(6)^{c)}$ & \\
\hline$\left[(T M E D A) L i\left\{\left(C_{4} H_{2} S\right)-5-M e\right\}\right]_{2}$ & $7.55^{b)}$ & $174.8^{b)}$ & - & [65] \\
\hline$\left[(\mathbf{P M D E T A}) \operatorname{Li}\left\{\left(\mathrm{C}_{4} \mathrm{H}_{2} \mathrm{~S}\right)-5-\mathrm{Me}\right\}\right]$ & $7.42^{b)}$ & $181.1^{b)}$ & $2.109(3)$ & [65] \\
\hline
\end{tabular}

a) crystals of $\mathbf{6}$ decomposed during NMR sample preparation; $b$ ) measured in benzene- $d_{6} \mathrm{c}$ ) only major domain; Li-C 2.273(18) all domains included.

Due to the similar permittivity of toluene $(2.38)$ and benzene $(2.28)^{[80]}$ a comparison of the resonances of $\mathbf{6}-\mathbf{8}$ to $\left.\left[(T M E D A) \mathrm{Li}\left\{\left(\mathrm{C}_{4} \mathrm{H}_{2} \mathrm{~S}\right)-5-\mathrm{Me}\right\}\right]_{2}\right)$ and [(PMDETA)$\left.\mathrm{Li}\left\{\left(\mathrm{C}_{4} \mathrm{H}_{2} \mathrm{~S}\right)-5-\mathrm{Me}\right\}\right]$ is possible. A similar trend in the ${ }^{13} \mathrm{C}$ chemical shifts from the dimers to the monomer, similar to $\mathbf{1 - 5}$, could be observed indicating a comparable stability of the solid-state aggregate in solution upon dissolving in toluene- $d_{8}$ or benzene- $d_{6}$, respectively.

In accordance with the results in Chapter 2.1, it can be concluded that methylsubstituted 2-thienyllithium can be deaggregated similar to 2-thienyllithum from the tetrameric aggregate in $\mathrm{Et}_{2} \mathrm{O}$ to dimeric structures (6-8 and [(TMEDA) $\mathrm{Li}\left\{\left(\mathrm{C}_{4} \mathrm{H}_{2} \mathrm{~S}\right)-5\right.$ $\mathrm{Me}\}]_{2}$ ) by the addition of the donor bases THF, DME, and TMEDA, respectively. A monomer can be obtained if the tridentate donor base PMDETA is applied. ${ }^{[65]}$ An influence of the methyl group either in 5- or 4-position on the aggregation was not observed. Larger substituents, e.g. $t \mathrm{Bu}$ - or $\mathrm{SiMe}_{3}$-groups or substitution at the 3-position may have a greater influence on the aggregation and lead to different aggregation states. 
Within this chapter it was shown that 2-thienyllithium as well as methyl-substituted 2-thienyllithium could be deaggregated by the addition of an adequate donor base. The application of diethyl ether led to tetrameric structures (1); THF, DME or TMEDA led to dimers (2-4, 6-8). A monomer was obtained from PMDETA, i.e. 5. In the solid state a shortening of the $\mathrm{C}-\mathrm{Li}$ distance from the tetramers to the monomers could be observed from SC-XRD experiments in both cases. Upon solvation in non-donating solvents, i.e. toluene- $d_{8}$ and benzene- $d_{6}$, a trend in the $\mathrm{C}_{\alpha}{ }^{13} \mathrm{C}$ chemical shifts to lower field from the tetramer to the monomer were observed indicating a structural retention in solution. Furthermore, the aggregation of $\mathbf{1 - 5}$ in solution could be confirmed by 2D NMR experiments (e.g. HOESY, DOSY) and proved the $\mathrm{C}_{\alpha}{ }^{13} \mathrm{C}$ chemical shifts as an indicator of the aggregation state for this class of lithium organic compound. The $\mathrm{C}_{\alpha}{ }^{13} \mathrm{C}$ chemical shifts and the average $\mathrm{Li}-\mathrm{C}_{\alpha}$ bond lengths are summarized in Table 2-4.

Table 2-4. Summary of the $\mathrm{C}_{\alpha}{ }^{13} \mathrm{C}$ chemical shifts [ppm] and average Li-C distances $[\AA]$ in 1-8.

\begin{tabular}{|c|c|c|c|}
\hline & $\delta\left(\mathbf{C}_{\alpha}\right)$ & av. $\mathrm{Li}-\mathrm{C}_{\boldsymbol{\alpha}}$ & Ref \\
\hline 1 & 166.8 & $2.282(4)$ & \\
\hline 2 & 170.8 & $2.228(4)$ & [65] \\
\hline 3 & 172.1 & $2.212(14)$ & \\
\hline 4 & 174.1 & 2.187 & [52] \\
\hline 5 & 180.1 & $2.115(3)$ & [65] \\
\hline$\left[\left(\mathbf{E t}_{2} \mathrm{O}\right) \mathbf{L i}\left(\mathrm{C}_{4} \mathbf{H}_{2} \mathrm{~S}\right)-5-\mathrm{Me}\right]_{4}$ & - & $2.270(14)$ & [49] \\
\hline 6 & -a) & $2.242(7)$ & \\
\hline 7 & 172.2 & $2.190(5)^{[65]}$ & \\
\hline 8 & 176.7 & $2.193(6)^{c)}$ & \\
\hline$\left[(\text { TMEDA }) \mathrm{Li}\left(\mathrm{C}_{4} \mathrm{H}_{2} \mathrm{~S}\right)-5-\mathrm{Me}\right]_{2}$ & $174.8^{b)}$ & - & [65] \\
\hline$\left[(\right.$ PMDETA $\left.) \mathrm{Li}\left(\mathrm{C}_{4} \mathrm{H}_{2} \mathrm{~S}\right)-5-\mathrm{Me}\right]$ & $181.1^{b)}$ & $2.109(3)$ & [65] \\
\hline
\end{tabular}

a) crystals of $\mathbf{6}$ decomposed during NMR sample preparation; $b$ ) measured in benzene- $d_{6 ;}$ c) only major domain; Li-C 2.273(18) 


\subsection{The Pentuple Ion of 2-Thienyllithium (9)}

Based on the knowledge of the structures 1-5 and considering the fact that the rarely observed triple ions fill the gap between monomeric and dimeric aggregation, there is likely to be an aggregate between the dimer/trimer and the tetramer. Larger aggregates are only known for HMPA coordinated amidonitrogen-lithium compounds, i.e. $\left[\left\{\mathrm{Li}(\mathrm{HMPA})_{4}\right\}\left\{\mathrm{Li}_{5}\left(\mathrm{~N}=\mathrm{CPh}_{2}\right)_{6}(\mathrm{HMPA})\right\}\right],{ }^{[81]}$ or from theoretical calculation of lithium chloride cluster. ${ }^{[82]}$

It turned out that the oxygen containing tridentate donor base diglyme does not form the expected monomer (Scheme 2-6, top) or triple ion (center) with 2-thienyllithium. The formation of a triple ion itself is unlikely compared to tris(trimethylsilyl)methyllithium $\left(\left(\mathrm{Me}_{3} \mathrm{Si}\right)_{3} \mathrm{CLi}\right)$ due to the absence of a steric shielding of thienyl groups to the exposed central lithium atom. An aggregate which had been hitherto unknown, a pentuple ion, was formed (bottom).

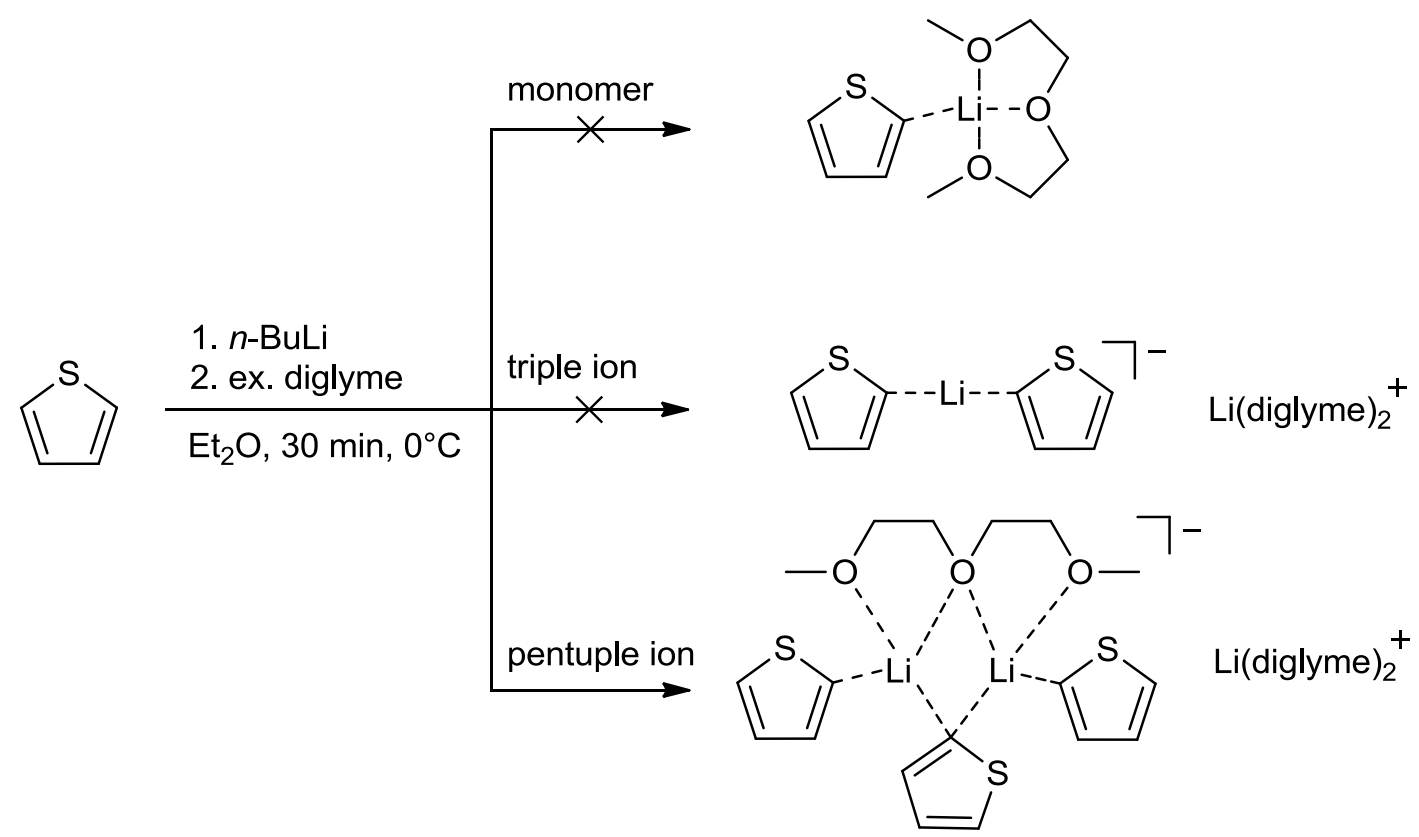

9

Scheme 2-6. Possible products of the lithiation of thiophene via $n$-BuLi at $0{ }^{\circ} \mathrm{C}$ and addition of diglyme: monomer (top), triple ion (center), pentuple ion of 9 (bottom).

[Li(Diglyme $\left.)_{2}\right]\left[(\right.$ Diglyme $\left.) \mathrm{Li}_{2}\left(\mathrm{C}_{4} \mathrm{H}_{3} \mathrm{~S}\right)_{3}\right]$ (9) crystallizes in the orthorhombic space group Pbca with a complete solvent separated ion pair (SSIP) in the asymmetric unit. The anion of the pentuple ion consists of two lithium cations and three anionic thienyl 
moieties (Figure 2-10). One of the thienyl moieties coordinates both lithium ions in a $\mu$-bridging motif similar to the one found in the $\mathrm{Li}_{2} \mathrm{C}_{2}$ dimeric arrangement in $\mathbf{2 - 4}$. One lithium atom is located above the thienyl ring plane and the other one underneath. Each of the remaining thienyl anions is bonded to a lithium atom via $\mathrm{C}_{\alpha}$ in a $\sigma$-bond manner that is frequently found in monomeric lithium organics, e.g. 5. The central diglyme oxygen atom bridges both lithium atoms forming a $\mathrm{LiCLiO}$ four-membered ring. The coordination spheres of the lithium atoms are completed by the terminal oxygen atoms of the diglyme. The third lithium atom is chelated by two diglyme molecules forming the cation of the SSIP. While the aggregation of 9 can be established unequivocally based on the data obtained by the X-ray experiments, it is not feasible to discuss bond lengths and angles in detail. The severe positional disorder in the structure is the reason for the low scattering power of the crystals. ${ }^{[83]}$ However, a stable refinement using chemical restraints and, where necessary, constraints, was possible, vide infra.

To the best of my knowledge, this structural motif of a pentuple ion, an anion consisting of two lithium cations and three carbanions forming the anion of a SSIP, has neither been reported as solid-state structure nor in solution up to now.
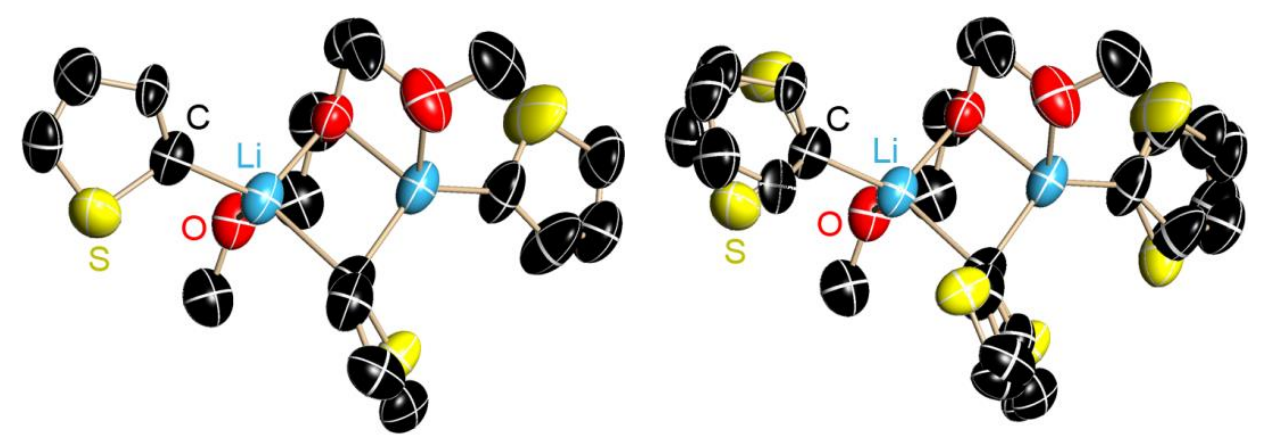

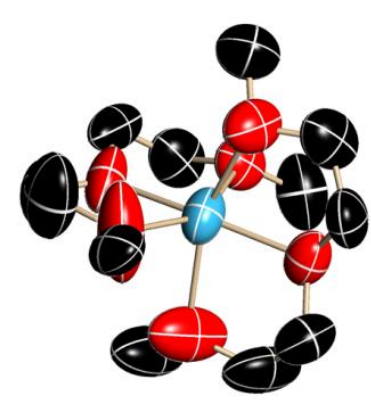

a

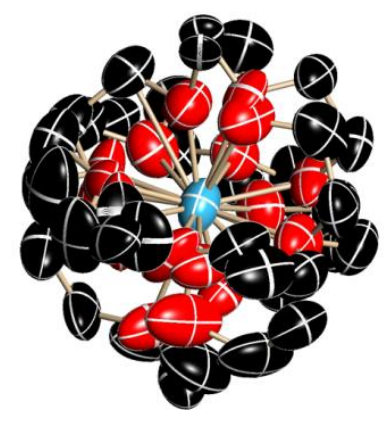

b

Figure 2-10. Molecular structure of the pentuple ion [2-thienyllithium diglyme $]_{3}$ (9). Anisotropic displacement parameters are depicted at $50 \%$. Major domain of $\mathbf{9}$ (a, left); major and minor positions of 9 (b, right). Hydrogen atoms are omitted for clarity. 
Suitable crystals of 9 were grown in an ethereal solution. The reaction mixtures were stored at temperatures between $0{ }^{\circ} \mathrm{C}$ and $-80{ }^{\circ} \mathrm{C}$, proving $-19^{\circ} \mathrm{C}$ to give the best conditions for crystallisation. XRD-experiments of 9 were performed on different X-ray devices, i.e. an in-house Mo-I $\mu \mathrm{S}$ (INCOATEC MICROFOCUS SOURCE) ${ }^{[84]}$, a Cu-rotating anode (Prof. Dr. G. M. Sheldrick, Göttingen), and at the beamline 15 ID-B (ChemMatCARS) at the Advanced Photon Source (APS) of the Argonne National Laboratory (Chicago). The herein presented structure of $\mathbf{9}$ was obtained from a data set measured on a Mo-I $\mu$ S.

As structure 9 only contains light atoms, the use of $\mathrm{Cu}$ - instead of Mo-radiation $(\mathrm{Cu}-$ $\mathrm{K}_{\alpha}: 1.51043 \AA$; Mo- $\mathrm{K}_{\alpha}: 0.71073 \AA$ ) is mandatory to improve the scattering power significantly. ${ }^{[85]}$ Therefore a data set was collected on a copper source. Unfortunately, the use of copper radiation did not show significant improvement of data quality, which can only be explained by poor crystal quality. Eventually, the $\mathrm{Cu}$ data set had to be discarded in favour of the Mo data set because of the much higher redundancy and completeness of the latter. A comparison of the data sets is listed in Table 2-5.

Table 2-5. Comparison of the data sets collected on Mo-I $\mu \mathrm{S}, \mathrm{Cu}$ source and synchrotron.

\begin{tabular}{llll}
\hline criteria & Mo- $\mathbf{I} \mathbf{S}$ & $\mathbf{C u}$ & APS \\
\hline Wavelength $[\AA]$ & 0.71073 & 1.54178 & 0.3936 \\
$T[\mathrm{~K}]$ & 100 & 100 & 12 \\
$R_{\text {int }}$ & 0.1626 & 0.0701 & 0.0971 \\
Resolution $[\AA]$ & 0.90 & 0.85 & 0.80 \\
Unique reflexes & 5410 & 4997 & 7430 \\
I/sigma & 14.99 & 8.37 & 11.80 \\
Completeness [\%] & 99.7 & 73.5 & 98.2 \\
Redundancy & 30.36 & 3.37 & 7.77 \\
$R 1$, (all data) & 0.1381 & 0.1263 & 0.1786 \\
$w R 2$ (all data) & 0.3630 & 0.3828 & 0.4740 \\
Resid. density [e/ $\left./ \AA^{3}\right]$ & $0.779 /-0.461$ & $0.548 /-0.39$ & $1.36 /-0.72$ \\
\hline
\end{tabular}

In hope that the "brightest X-ray beam in the Western Hemisphere"[18] would improve the resolution and thus the information provided by the crystal structure, XRD experiments were performed at the Advanced Photon Source (APS) of the Argonne National Laboratory (Chicago) (Figure 2-11). 


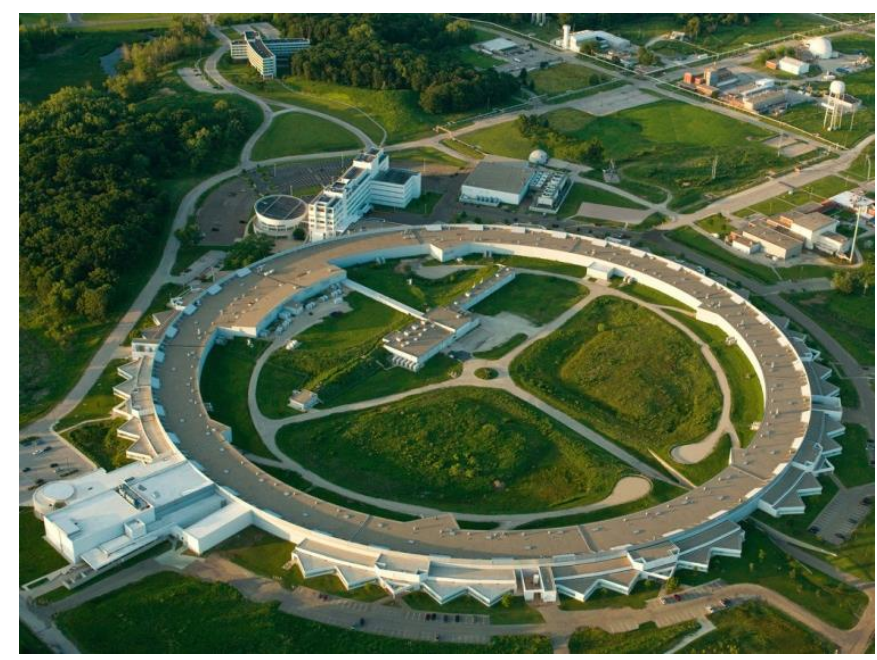

Figure 2-11. Aerial photo of the Advanced Photo Source. ${ }^{[18]}$

Freshly grown crystals from commercially available starting materials were measured at helium temperature $(12 \mathrm{~K})$ and with synchrotron radiation $(\lambda=0.3936 \AA)$. Six data sets of different quality were obtained during this experiment (for key data see Table 2-5 right column). The availability of liquid helium for crystal cooling was a further advantage that led us to conduct experiments at the APS. It was expected that the lower temperature, "freezing" the libration of the atoms in the crystal, would reduce the positional disorder of the diglyme molecules in the anion and enables a more exact deconvolution of the positional parameters from thermal motion. The application of shorter wavelength is counterintuitive to the above mentioned usage of $\mathrm{Cu}$-radiation because the scattering power decreases with the used wavelength, but this disadvantage of the used radiation is more than compensated by the colossal flux provided by the synchrotron beam, which is $\sim 10^{10}$ times more intense compared to conventional X-ray sources. This leads to shorter exposure times especially for very small crystals, therefore to shorter experiments and the survival of the air-sensitive crystals is more likely.

After a careful evaluation of the data sets it turned out that the data obtained by the I $\mu$ S-measurement, even compared to the data from APS (Table 2-5, right column), still seemed to be best. This is indicated by the stable and reliable refinement and lower residual density by including data to the same resolution limit. It can be explained by the lower data quality of the APS data set by the observed, however unintended, overexposed low angle data. Even with full attenuation and short exposure times it was not possible to obtain a smooth diffraction pattern due to the high flux of the beam. This 
led to scaling problems because the intensity of the low angle reflections was underestimated.

This unknown aggregation mode was examined via NMR experiments as well. It was of great interest, if the intriguing solid-state structure of $\mathbf{9}$ is retained in solvation as it was shown for the other 2-thienyllithium aggregates.

Crystals of 9 were transferred to NMR tubes under inert conditions and dissolved in toluene- $d_{8}$, similar to the procedure for 1-5. Only one set of signals was detected in the ${ }^{1} \mathrm{H}$ NMR spectrum as well as in the ${ }^{13} \mathrm{C}$ NMR spectrum. The resonance of the $\mathrm{C}_{\alpha}$ atom ( $\delta=172.6 \mathrm{ppm})$ is in the range of the $\mathrm{C}_{\alpha}$ atoms of the dimers $\mathbf{2 - 4}$ and no further signal set in the ${ }^{1} \mathrm{H}$ NMR spectrum appeared at low temperature (203 K) (see Scheme 2-8). Again the described temperature dependent shift to low field occurred.

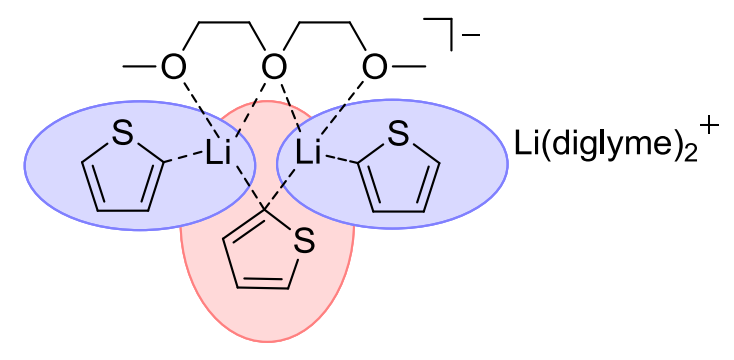

Scheme 2-7. Monomeric (blue) and dimeric (red) subunits of 9.

Two different signal sets would be expected if the aggregation of the solid state was retained in solution. For comparison, the $\mathrm{C}_{\alpha}{ }^{13} \mathrm{C}$ chemical shift of the dimer $\mathbf{3}$ is $\delta=172.1$ and $\delta=180.1 \mathrm{ppm}$ for the monomer 5. Two thienyl moieties in 9 are coordinated terminally to one lithium cation, showing a monomeric motif (Scheme 2-7, blue) and therefore a larger low field shift would be expected. The bridging $\mathrm{C}_{\alpha}$ atom of the third thienyl moiety (Scheme 2-7, red) would show a resonance at higher field. Nevertheless, the possibility of the resonances to coincide cannot be discarded unequivocally, although this serendipity is estimated to be rather unrealistic. This could be an indicator for a different aggregation state in solution. A second signal at $180 \mathrm{ppm}$ for the monomerically bonded thienyl moiety should be observed if the pentuple ion stays intact in solution. Either a fast equilibrium, which cannot be resolved at $203 \mathrm{~K}$, or a different aggregate is favored in solution. 


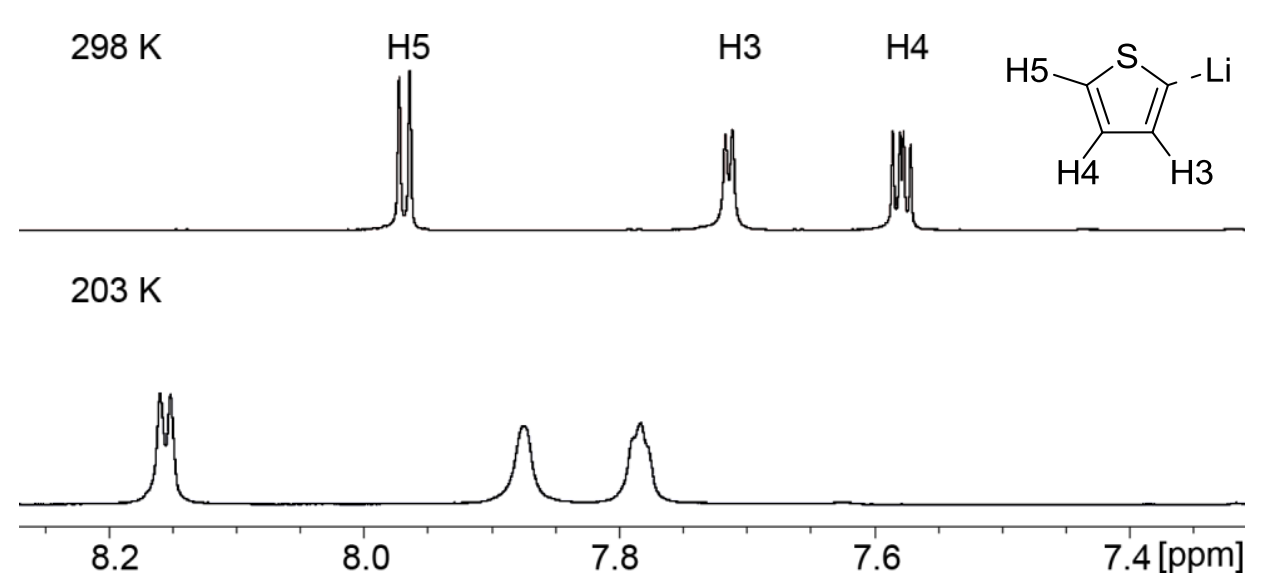

Scheme 2-8. Low temperature (bottom) and room temperature (top) ${ }^{1} \mathrm{H}$ NMR spectra of 9 in toluene- $d_{8}$. Only the range of the thienyl protons is displayed.

Two broad signals are found in the low temperature ${ }^{7} \mathrm{Li}\left\{{ }^{1} \mathrm{H}\right\}$ NMR spectrum indicating at least two different environments for the lithium cations. This could be a hint to a fast exchange between the different thienyl moieties. Surprisingly no signal splitting was detected in the ${ }^{1} \mathrm{H}$ NMR spectra at the lowest possible temperature.

To summarize, 2-thienyllithium does not form the anticipated monomer or triple ion with the tridentate donor base diglyme but rather an unexpected SSIP, the pentuple ion. Three anionic thienyl moieties and two lithium atoms form the anion and a solvent separated lithium atom the cation of the solvent separated ion pair (SSIP). Extensive crystallization attempts and XRD experiments led to the unequivocally determined solid-state structure. Mononuclear NMR studies indicate that the solid-state structure is at least not fully retained in solution. Moreover a change of aggregation is supported. A deaggregation assumption is buoyed by recently conducted multi-dimensional NMR experiments (e.g. HOESY) and support a fast exchange which may involve a dimeric structure. ${ }^{[86]}$ 


\subsection{Aggregation of 2-Furyllithium}

The aggregation of 2-furyllithium is far less understood than the aggregation of 2thienyllithium and its derivatives. Only two dimeric structures of lithiated benzofuran, $\left[(\mathrm{TMEDA}) \mathrm{Li}\left(\mathrm{C}_{8} \mathrm{H}_{5} \mathrm{O}\right)\right]_{2}{ }^{[54]}$ and $\left[\left[\left(\mathrm{Pr}_{2} \mathrm{O}\right) \mathrm{Li}\left(\mathrm{C}_{8} \mathrm{H}_{5} \mathrm{O}\right)\right]_{2}\right]^{[87]}$ have been structural investigated. Further preliminary results on the aggregation of 2-furyllithium, i.e. $\left[\left\{(\mathrm{THF})_{4} \mathrm{Li}_{2}\left(\mathrm{C}_{4} \mathrm{H}_{3} \mathrm{O}\right)_{2}\right\}\right]_{2}$ and $\left[(\text { Diglyme }) \mathrm{Li}\left(\mathrm{C}_{4} \mathrm{H}_{3} \mathrm{O}\right)\right]_{\infty}$ were already presented in my diploma thesis (Figure 2-12). ${ }^{[65]}$ The empirical formula of $\left[(\mathrm{THF})_{4} \mathrm{Li}_{4}\left(\mathrm{C}_{4} \mathrm{H}_{3} \mathrm{O}\right)_{4}\right]$ indicates a tetrameric aggregation of 2-furyllithium with tetrahydrofuran. On closer inspection the structure revealed two furyl- $O$-bridged dimeric subunits (Figure 2-12 left, blue planes) instead of a genuine tetramer, due to the elongated $\mathrm{Li}-\mathrm{Li}$ distance of the isosceles $\mathrm{Li}_{3}$-triangles (av. short Li-Li: 2.538(4) $\AA$; long $\mathrm{Li}-\mathrm{Li}: \quad 3.387(4) \AA$ ). $\left[(\text { Diglyme }) \mathrm{Li}\left(\mathrm{C}_{4} \mathrm{H}_{3} \mathrm{O}\right)\right]_{\infty}$ forms a coordination polymer in the solid state. Two 2furyllithium moieties form dimeric subunit, similar to the THF aggregate, in which the furyl oxygen and a terminal oxygen of the diglyme coordinate to a neighbouring lithium atom of the adjacent dimer (right).

Furthermore, the solid-state structures of the dimeric 2-lithiated benzofuran derivatives $\left[(T M E D A) L i\left(\mathrm{C}_{8} \mathrm{H}_{5} \mathrm{O}\right)\right]_{2}{ }^{[54]}$ and $\left[\left(i \mathrm{Pr}_{2} \mathrm{O}\right) \mathrm{Li}\left(\mathrm{C}_{8} \mathrm{H}_{5}(\mathrm{Br}) \mathrm{O}\right)\right]_{2}{ }^{[87]}$ have been determined.

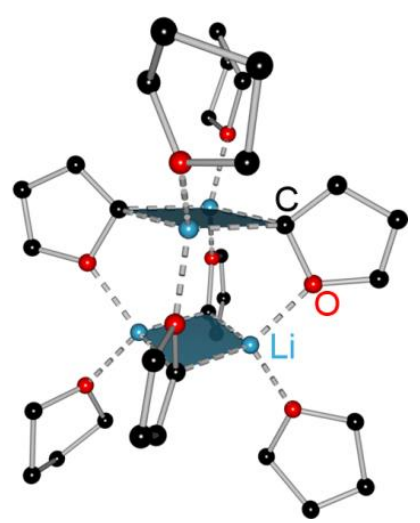

a

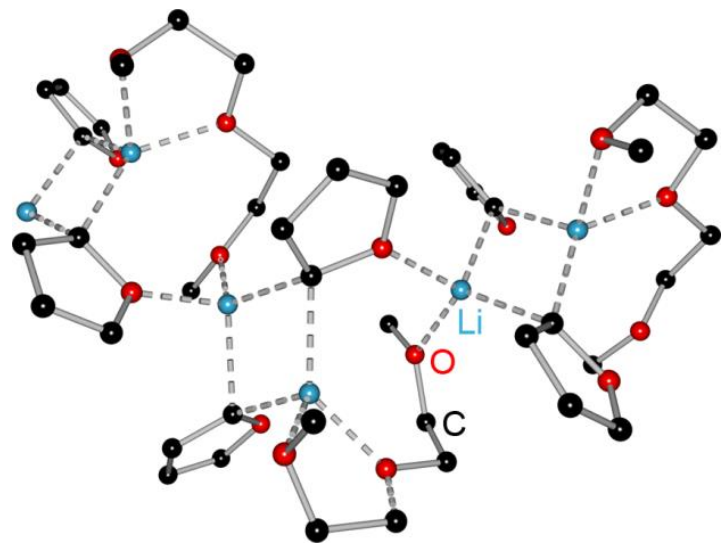

b

Figure 2-12. Known solid-state structures of 2-furyllithium with THF (a, left; dimeric $\mathrm{Li}_{2} \mathrm{C}_{2}$-plane in blue) and diglyme (b, right).

A coordination of the ring oxygen atom to a neighbouring lithium atom takes place in all known structures. This fact, plus the dominating motif of the structure, a $\mathrm{C}_{2} \mathrm{Li}_{2}$ 
ring, leading to dimeric subunits was the reason for continuing interest in 2-furyllithium.

Further investigations indicate a different behaviour of 2-furyllithium (the formation of dimeric subunits) in comparison to its heavier homologue 2-thienyllithium, which forms with diethyl ether a tetramer (1), with THF, DME, TMEDA, respectively, dimers (2-4) and with PMDETA a monomer (5). Unexpected structural motifs of 2-furyllithium could be determined, if these donor bases were applied.

\subsection{1 [(PMDETA $\left.)_{2} \mathrm{Li}_{6} \mathrm{O}_{2}\left\{\left(\mathrm{C}_{4} \mathrm{H}_{2} \mathrm{O}\right)-5-\mathrm{Me}\right\}_{4}\right](10)$}

In a deaggregation study of 5-methyl-2-furyllithium with the tridentate donor base PMDETA the formation of a monomer similar to $\mathbf{5}$ was expected.

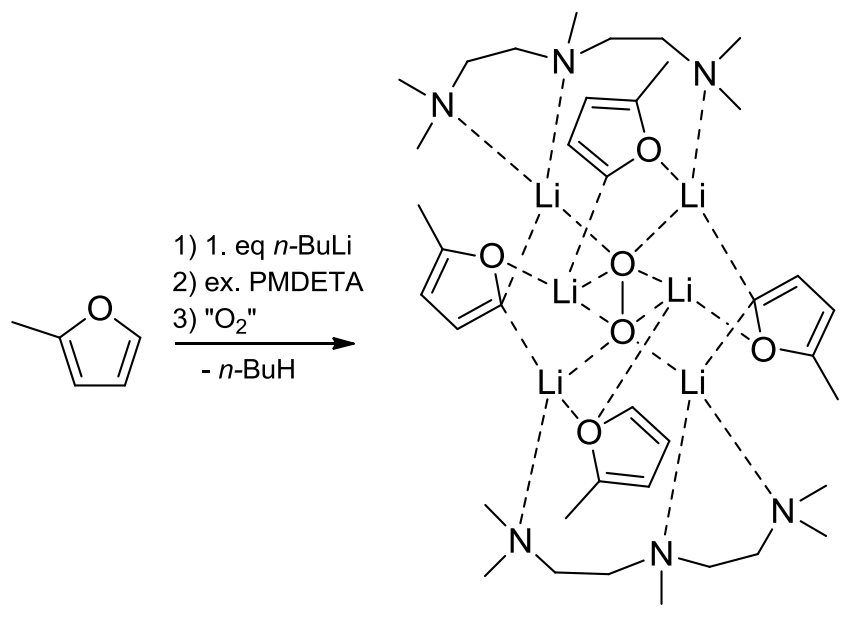

10

Scheme 2-9. Insertion of peroxide in 5-methyl-2-furyllithium with PMDETA.

It turned out that the flask was not sealed properly or via incautiousness the reaction mixture was exposed to air for a short period of time (Scheme 2-9). Nevertheless, colorless crystals of $\mathbf{1 0}$ grew after a few days. $\mathbf{1 0}$ crystallized in the orthorhombic space group Pbca with half the molecule in the asymmetric unit. The whole molecule is shown in Figure 2-13. 


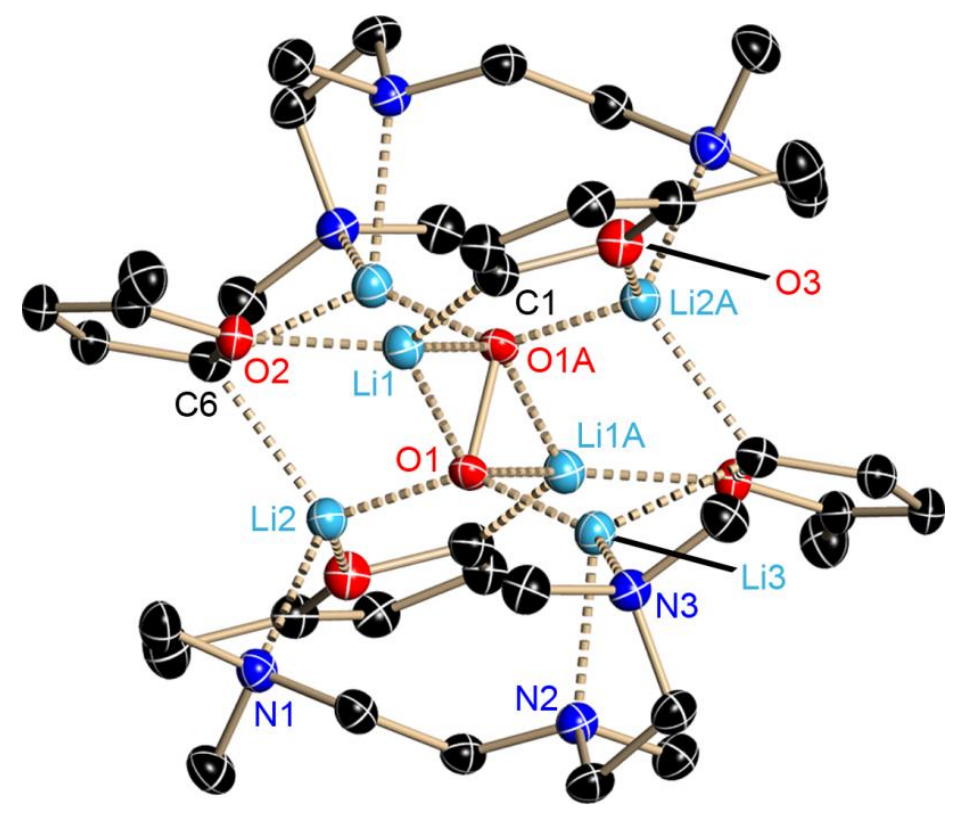

Figure 2-13. Molecular structure of 10. Anisotropic displacement parameters are depicted at the 50\% probability level. Hydrogen atoms are omitted for clarity. Symmetry equivalent atoms are labeled with A.

The center of the structure is a peroxide $\mathrm{O}_{2}{ }^{2-}$, which is $\mu$-bridged by the lithium cation Li1 and its symmetry equivalent Li1A. The $\mathrm{O}-\mathrm{O}$ bond length of 1.5483(17) $\AA$ is longer compared to $\mathrm{H}_{2} \mathrm{O}_{2}(1.453(7) \AA)^{[88]}$ but in the range of $\mathrm{O}-\mathrm{O}$ distance found in reported lithium peroxide inclusion compounds. ${ }^{[89]}$

The coordination sphere of Li1 is filled up to four by the carbanion of a 5-methyl-2furyl moiety (C1) and the oxygen atom of a second 5-methyl-2-furyl molecule (bearing C6). The lithium atoms $\mathrm{Li} 2$ and $\mathrm{Li} 3$ are end-on coordinated to $\mathrm{O} 1$ of the peroxide anion. $\mathrm{Li} 2$ is also bonded to the $\mathrm{C}_{\alpha}$ atom of the $\mathrm{C} 6$ bearing 5-methyl-2-furyl ring, N1 of a PMDETA molecule and the oxygen atom of a 5-methyl-2-furyl moiety (bearing C1A). The coordination sphere of Li3 is completed by the two residual nitrogen atoms of the PMDETA molecule (N2 and N3) and O2A (the symmetry equivalent of furyl ring bearing C6). Selected bond lengths and angles of $\mathbf{1 0}$ are summarized in Table 2-6.

Table 2-6. Selected bond lengths $[\AA]$ and angles $\left[{ }^{\circ}\right]$ of $\mathbf{1 0}$.

\begin{tabular}{llll}
\hline O1-O1A & $1.5483(17)$ & Li1-O1 & $1.903(3)$ \\
Li1-C1 & $2.088(3)$ & Li1-O1A & $1.918(3)$ \\
Li2-C6 & $2.220(3)$ & Li1-O2 & $1.935(3)$ \\
Li3-C6 & $2.212(3)$ & Li2-O1 & $1.977(2)$ \\
Li2-N1 & $2.174(3)$ & Li3-O1 & $1.945(2)$ \\
Li3-N2 & $2.180(3)$ & O1-Li1-O1A & $132.21(7)$ \\
Li3-N3 & $2.151(3)$ & Li2-C6-Li3A & $76.13(13)$ \\
\hline
\end{tabular}


The inclusion of peroxide ions in lithium organics is quite seldom and the formation of peroxo anions not yet understood. ${ }^{[89]}$ The source of the peroxide was in most cases the exposure to air or not completely degassed solvents or starting materials. In the reported complexes either six, ${ }^{[89 e]}$ seven, ${ }^{[89 a, 89 c]} e^{\text {eight }}{ }^{[89 b]}$ or nine ${ }^{[89 \mathrm{~d}]}$ lithium atoms are bonded to the peroxide, whereas three or four lithium atoms are $\mu$-bridging coordinated to the peroxide. The peroxide anion in $\mathbf{1 0}$ is only coordinated by six lithium atoms (two in a $\mu$-bridging motif), representing one of the smallest lithium peroxide complexes reported so far. In this way the peroxide is shielded and further lithium atoms cannot be bonded. In the structures with six or more lithium atoms, the lithium atoms are coordinated by nitrogen containing molecules similar to $\mathbf{1 0}$.

The crystals of $\mathbf{1 0}$ decomposed during the transfer to NMR tubes and new crystals could not be obtained neither from the same batch nor from further synthesis under the same conditions. This indicates an insertion of air in the first batch.

\subsection{2 $\left[\left\{\mathrm{Li}(\mathrm{DME})_{2}\right\}_{2} \mathrm{Li}_{12}\left\{\left[\mathrm{C}_{4} \mathrm{H}_{3} \mathrm{O}\right]_{8}\left[\mathrm{OCH}_{3}\right]_{6}\right\}\right](11)$}

Similar to 5-methly-2-thienyllithium, 5-methyl-2-furyllithium should form a dimer, if DME is applied, but an unexpected DME cleavage took place. 11 was prepared in the same way as the 2-thienyllithium compounds. One equivalent $n$-BuLi was added to freshly distilled furan in diethyl ether at $0{ }^{\circ} \mathrm{C}$. After 30 minutes 2 eq. of DME were added and stirred for another 30 minutes. The reaction mixture was stored at $-20{ }^{\circ} \mathrm{C}$ and suitable crystals for XRD-experiments were obtained after a few days. 11 crystallizes in the orthorhombic space group Pbca with the whole molecule in the asymmetric unit. An ether cleavage reaction took place and the resulting, unexpected structure is presented in Figure 2-14. 


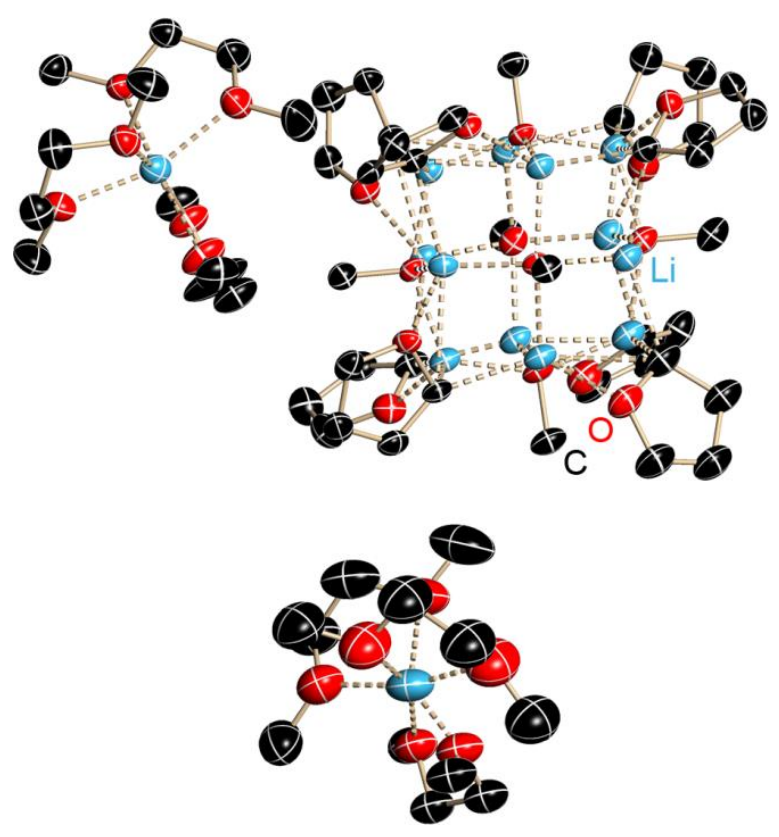

Figure 2-14. Isolated structure of the reaction of 2-furyllithium with DME (11). Anisotropic displacement parameters are depicted at $50 \%$. Hydrogen atoms and positional disorder of the DME molecules and furyl moieties are omitted for clarity.

Ether cleavage occurs unintentionally in reactions of alkaline metals with ethers and could be avoided by either lowering the reaction temperature or by avoiding the presence of $\alpha$-hydrogen atoms. ${ }^{[90]}$ The methoxy anions in the solid-state structure of $\mathbf{1 1}$ can be explained by a cleavage of DME. A decomposition of diethyl ether would lead to ethoxy groups instead. The proposed reaction mechanism of the DME cleavage is shown in Scheme 2-10. ${ }^{[90 \mathrm{~b}]}$

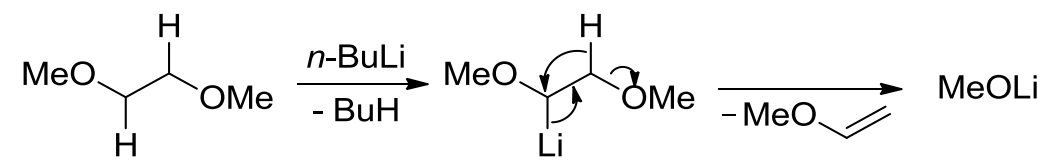

Scheme 2-10. Mechanism of the cleavage of DME with $n$-BuLi. ${ }^{[00 b]}$

The anion is composed of 12 lithium cations, eight 2-furyl and six methoxy anions. Two lithium cations, each coordinated by two DME molecules, form the two counterions of the solvent separated ion pair (SSIP). The oxygen atoms of the six methoxy groups form a regular octahedron (Figure 2-15). The 12 lithium atoms of the SSIP anion are $\mu$-bonded to two methoxy oxygen atoms capping the edges of the octahedron and forming a cuboctahedron. The $\mathrm{C}_{\alpha}$ carbanions of the furyl moieties are capping the lithium triangles in a $\mu_{3}$-fashion. This is a common motif in organolithium 
compounds, e.g. tetramers and hexamers (vide supra). Similar to the structures of $\left[\left\{(\mathrm{THF})_{4} \mathrm{Li}_{2}\left(\mathrm{C}_{4} \mathrm{H}_{3} \mathrm{O}\right)_{2}\right\}\right]_{2}$ and $\left[(\operatorname{diglyme}) \mathrm{Li}\left(\mathrm{C}_{4} \mathrm{H}_{3} \mathrm{O}\right)\right]_{\infty}$ the ring oxygen coordinates to a neighbouring lithium atom. Four of the furyl moieties are positional disordered leading to a coordination number of four to five for the lithium atoms in the anion of $\mathbf{1 1}$.

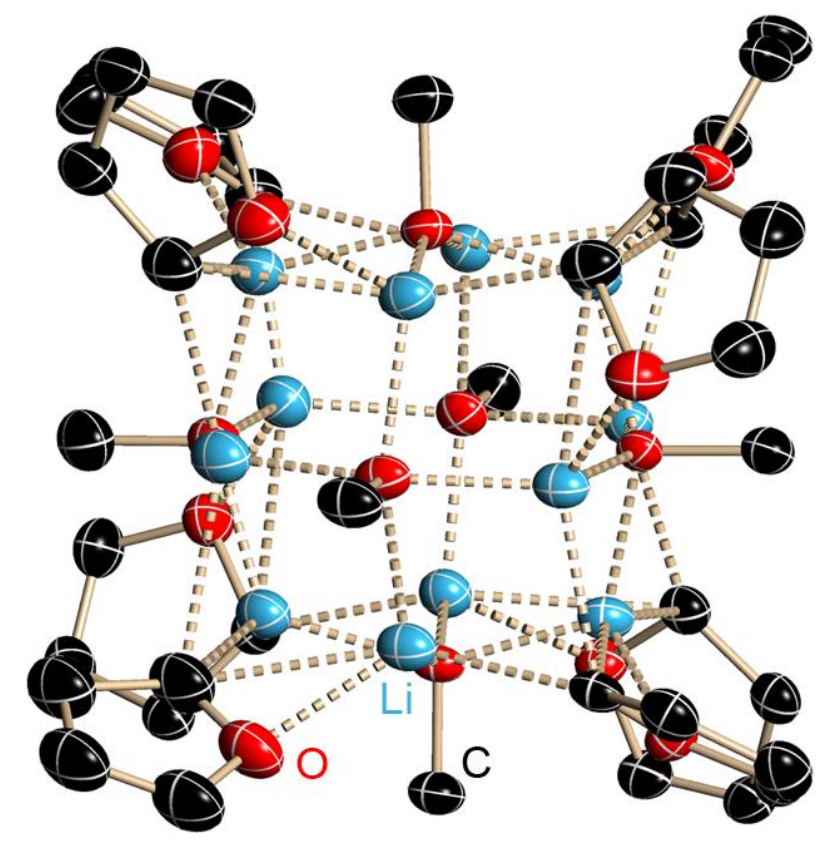

Figure 2-15. Anion of 11.

While the aggregation of 9 can be established unequivocally based on the data obtained by the X-ray experiments, it is not feasible to discuss bond lengths and angles in detail. The severe positional disorder in the structure is the reason for the low scattering power of the crystals. ${ }^{[83]}$ However, a stable refinement using chemical restraints and, where necessary, constraints, was possible.

In the previously reported structures of 2-furyllithium and 2-benzofuryllithium the formation of dimers or dimeric subunits could be observed. Addition of DME or PMDETA should lead to a dimeric or a monomeric structure, respectively. The structures of 10 and 11 presented herein show varying structural motifs, i.e. a peroxide inclusion and a DME ether cleavage. Therefore 2-furyllithium cannot be easily compared to its heavier homologue 2-thienlylithium. Further investigation may prove if a deaggregation study comparable to the studies on 2-thienyllithium is possible or if further uncommon aggregation motifs can be detected. 



\section{Late Transition Metal Complexes of BIS(2-THIENYL)DIETHYLAMINOPHOSPHANE AND MODIFICATIONS}

$\left(\mathrm{C}_{4} \mathrm{H}_{3} \mathrm{~S}\right)_{2} \mathrm{PNEt}_{2}$ (12) came to scrutiny due to the fact that it contains an amino group for the coordination of hard metals. Moreover the central phosphorus as well as the sulfur atom of the thienyl group (thi) are expected to coordinate softer metals, in particular late transition metals, according to Pearsons concept. ${ }^{[40]}$

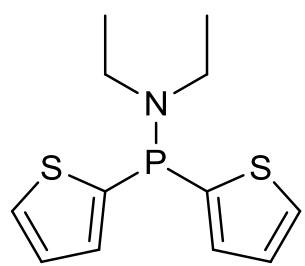

Scheme 3-1. Bis(2-thienyl)diethylaminophosphane (12).

There are many examples of $\mathrm{Mn},{ }^{[91]} \mathrm{Re}^{[92]}, \mathrm{Rh}^{[93]}$ and $\mathrm{Os}^{[94]}$ complexes reported in the literature investigating the coordination of $\mathrm{P}$-thienyl motifs to get a deeper insight into the mechanism of the hydrodesulfurization (HDS) of crude petroleum. ${ }^{[95]}$

In 2011 the worldwide consumption of petroleum was more than 87 million barrels per day (32 thousand million barrels / year). ${ }^{[96]}$ As long as the change to sustainable energy, e.g. wind, solar, geothermal energy is not conducted fossil fuels will be the most consumed energy and it remains a major task to provide pure and byproduct-free fuels. Since Victor Meyer found out that thiophene is one of the impurities in coal tar products, i.e. benzene, ${ }^{[97]}$ at the end of the $19^{\text {th }}$ century, a lot of effort was made to purify gasoline from sulfur containing compounds (e.g. thiols, thioethers, disulfides, and thiophenes). By doing so, catalytic converters can be protected from catalyst poisoning. ${ }^{[98]}$

The interaction of thiophene and its side chain substituted derivatives with (late) transition metals have been in focus for several years. Thiophene is a versatile ligand for which various coordination modes have been observed (Scheme 3-2). ${ }^{[99]}$ 
<smiles>[M]S1=C=CC=C1</smiles>

S-bound<smiles>[M]C1C=CSC=C1</smiles>

$\eta^{2}$-bound

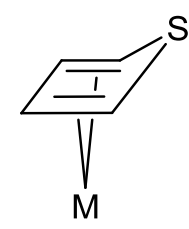

$\eta^{4}$-bound

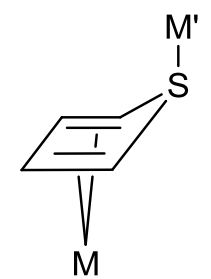

$\eta^{4}, S-\mu_{2}$-bound<smiles>[M]c1cccs1</smiles>

$\eta^{5}$-bound

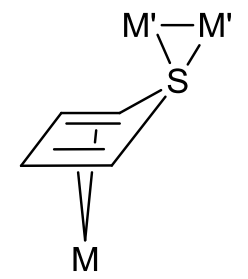

$\eta^{4}, \mathrm{~S}-\mu_{3}$-bound

Scheme 3-2. Possible bonding modes of thiophene. ${ }^{[99 c]}$

Recently, Yang et al. reported the introduction of a PThi 2 -moiety to stabilize germylene ligands as promising precursors for further metal coordination. ${ }^{[100]}$

Within this chapter the coordination of $\mathbf{1 2}$ to different late transition metals is presented, as well as the transformation of $\mathbf{1 2}$ to bis-(2-thienyl)phosphane ( $\left.\mathrm{Thi}_{2} \mathrm{PH}\right)$ via the chlorine intermediate. $\mathrm{Thi}_{2} \mathrm{PH}$ is expected to be an even more promising $P, S$-ligand and is envisaged to act as a $S, S-; P, S$ - or $\mu_{2}-P, S$ donor. 


\subsection{Late Transition Metal Complexes of $\left(\mathrm{SC}_{4} \mathrm{H}_{3}\right)_{2}\left(\mathrm{NEt}_{2}\right) \mathbf{P}$ (12)}

The precursor $\mathrm{Cl}_{2} \mathrm{PNEt}_{2}$ can be turned into the $P, N, S$-ligand $\left(\mathrm{C}_{4} \mathrm{H}_{3} \mathrm{~S}\right)_{2} \mathrm{PNEt}_{2}$ (12) via a Grignard reaction with 2-bromothiophene. ${ }^{[101]}$ The addition of a late transition metal salt led to mono- and binuclear metal complexes (Scheme 3-3, left pathway) or it can be reduced to bis(2-thienyl)phosphane 19 via bis(2-thienyl)chlorophosphane 20 (right pathway).<smiles>CCN(Cl)P(Cl)Cl</smiles><smiles>[X][X]([X])([3H])[3H]</smiles><smiles>CCN(c1cccs1)c1cccs1</smiles>

13: $\mathrm{M}=\mathrm{Ni} ; \mathrm{X}=\mathrm{Cl}, \mathrm{Br}$

15: $\mathrm{M}=\mathrm{Pd} ; \mathrm{X}=\mathrm{Cl}, \mathrm{Br}$

17: $\mathrm{M}=\mathrm{Ir} ; \mathrm{X}=\mathrm{Cl}, \mathrm{Br}$

18: $\mathrm{M}=\mathrm{Au} ; \mathrm{X}=\mathrm{Cl}$

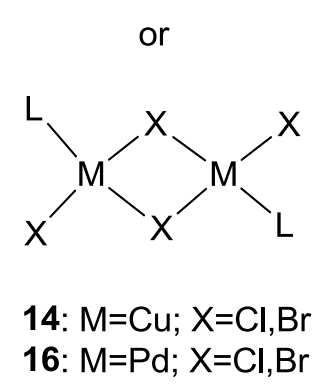<smiles>[CH2]C</smiles><smiles>ClP(c1ccccc1)c1cccs1</smiles>

16: $\mathrm{M}=\mathrm{Pd} ; \mathrm{X}=\mathrm{Cl}, \mathrm{Br}$<smiles>O=P(O)(c1cccs1)c1cccs1</smiles>

22
19<smiles>c1csc(P(c2cccs2)c2cccs2)c1</smiles>

21

Scheme 3-3. Synthesis of $\mathbf{1 2}$ and reactions performed with this ligand.

The challenging reduction and the formation of byproducts will be discussed later in this chapter. It is noteworthy to mention that a careful separation of the formed 
magnesium halide salts $(\mathrm{MgXY} \cdot 4$ thf $(\mathrm{X}=\mathrm{Cl}, \mathrm{Y}=\mathrm{Br}))$ is crucial to obtain the pure compound after performing the Grignard reaction with 2-bromothiophene and $\mathrm{NEt}_{2} \mathrm{PCl}_{2} \cdot{ }^{[102]}$ Repeated washings of the crude product with $n$-pentane and separation from the precipitates led to the pure compound 12. Without this work-up a variety of crystals can be obtained containing only magnesium bromide $\left(\mathrm{MgBr}_{2}\right)$, chloride $\left(\mathrm{MgCl}_{2}\right)$ or bromide and chloride $(\mathrm{MgClBr})$, respectively. Due to their high solubility in polar solvents, these undesired salts can be transferred to further reactions, and they often crystallize with the desired product, when the solvent is changed. Therefore, it was crucial to investigate the magnesium halides with respect to their cell parameters and contents to quickly identify these compounds in any product/byproduct mixture. With the known cell parameters of the magnesium salts at hand one could assure the product unequivocally.

The metal complexes were obtained by a reaction of $\mathbf{1 2}$ with the late transition metal salts $\mathrm{NiCl}_{2}$ (diglyme), $\mathrm{CuCl}, \quad\left[\mathrm{PdCl}_{2} \cdot \mathrm{PhCN}\right], \quad[\mathrm{IrCl}(\mathrm{COD})]_{2}$ and $\mathrm{AuCl}\left(\mathrm{SMe}_{2}\right)$, respectively. A general synthesis path was applied to achieve the complexes 13-18 (Scheme 3-4). The adequate metal salt was dissolved in toluene and $\mathbf{1 2}$ was added, the reaction mixture stirred until the salt was completely dissolved, stored at $-20^{\circ} \mathrm{C}$ and single crystals were obtained after several days.

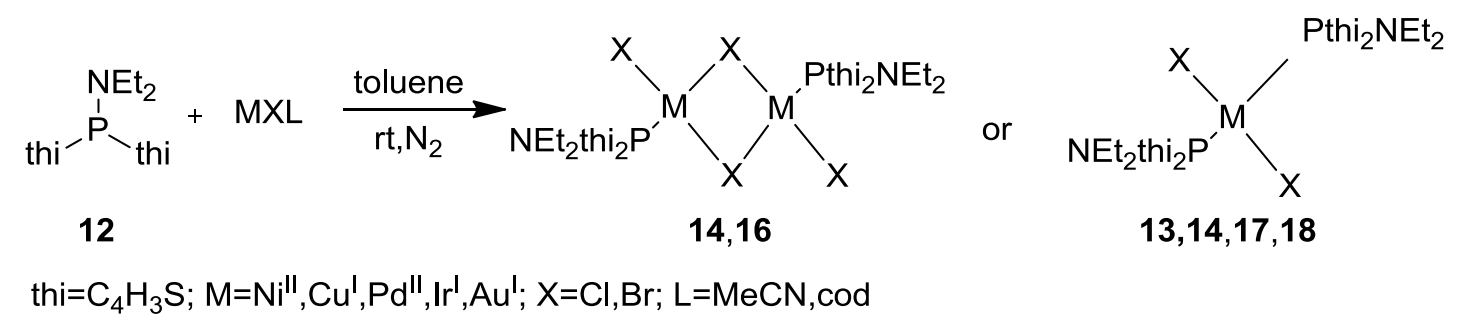

Scheme 3-4. General reaction scheme for the synthesis of metal complexes of $\mathbf{1 2 .}$

The soft late transition metals nickel, copper, palladium, iridium and gold (Figure 3-1) were chosen as they were foreseen to be attractive acceptors for the soft donor atoms phosphor and sulfur and to study their coordination behaviour towards 12. It was expected that no coordination to the hard nitrogen atom would takes place. X-ray diffraction was used to determine the crystal structure, hence the coordination geometry, of the aggregates formed between $\mathbf{1 2}$ and the late transition metals. These results will be discussed in the following chapter. 


\begin{tabular}{|c|c|c|c|}
\hline $\begin{array}{l}27 \\
\text { Co }\end{array}$ & $\begin{array}{l}28 \\
\mathrm{Ni}\end{array}$ & $\begin{array}{l}29 \\
\mathrm{Cu}\end{array}$ & $\begin{array}{l}30 \\
\mathrm{Zn}\end{array}$ \\
\hline $\begin{array}{l}45 \\
\text { Rh }\end{array}$ & $\begin{array}{l}46 \\
\mathrm{Pd}\end{array}$ & $\begin{array}{l}47 \\
\mathrm{Ag}\end{array}$ & $\begin{array}{l}48 \\
\mathrm{Cd}\end{array}$ \\
\hline $\begin{array}{l}77 \\
\text { Ir }\end{array}$ & $\begin{array}{l}78 \\
\mathrm{Pt}\end{array}$ & $\begin{array}{l}79 \\
\mathrm{Au}\end{array}$ & $\begin{array}{l}80 \\
\mathrm{Hg}\end{array}$ \\
\hline
\end{tabular}

Figure 3-1. Section of the periodic table of the elements.

\subsubsection{Nickel(II) Complex of 12 (13)}

Nickel complexes are a powerful tool for $\mathrm{C}-\mathrm{C}$ bond formations particularly in the organic synthesis. The name of Negishi is associated with Ni catalysis, his development brought the application of nickel into cross-coupling reactions. ${ }^{[35 \mathrm{a}, 35 \mathrm{~b}]}$ Phosphanes are often used as a ligand in the active complexes to stabilize the metal ion in the oxidation state zero. The cross-coupling reactions between Grignard reagents and $\mathrm{C}\left(s p^{2}\right)$-halides reported by Kumada is only one example. ${ }^{[103]}$

Following Scheme 3-4 for the synthesis of metal complexes of 12, 12 was added to a solution of the metal salt in toluene and stirred at room temperature. After completed solvation the reaction mixture was stored at $-20{ }^{\circ} \mathrm{C}$ and green crystals of $\mathbf{1 3}$ were obtained after several days. The nickel complex 13 crystallizes as a non-merohedral twin (BASF: 0.46 ) in the triclinic space group $P \overline{1}$. The nickel atom in $\mathbf{1 3}$ exhibits a distorted tetrahedral geometry and is coordinated by the phosphorus atom of two phosphane ligands and two halogen atoms (Figure 3-2). In all complexes, presented in this thesis, the halogen position is occupied by $\mathrm{Cl}$ or $\mathrm{Br}$, in changing ratios. Bromine origins form the uncrystallized Grignard reaction side product or from the metal salt used to obtain 13-18. Therefore, metal-halogen bond lengths are not discussed but were found to have expected values. The thienyl rings of $\mathbf{1 2}$ are, similarly to the 2thienyllithium structures $\mathbf{1 - 5}$, rotationally disordered along the $\mathrm{C}-\mathrm{P}$ vector. The site occupation factors (SOF) of the positional disorder of the thienyl moieties were given in the Crystallographic Section (Chapter 6.5).

A preference of the orientation of the thienyl rings towards the metal ion is not indicated in the solid-state structures. The distance of $>4.0 \AA$ is too large compared to distances in literature $(\sim 2.3-2.9 \AA)^{[104]}$ to show any interaction between nickel and thienyl-sulfur in $\mathbf{1 3 .}$ 


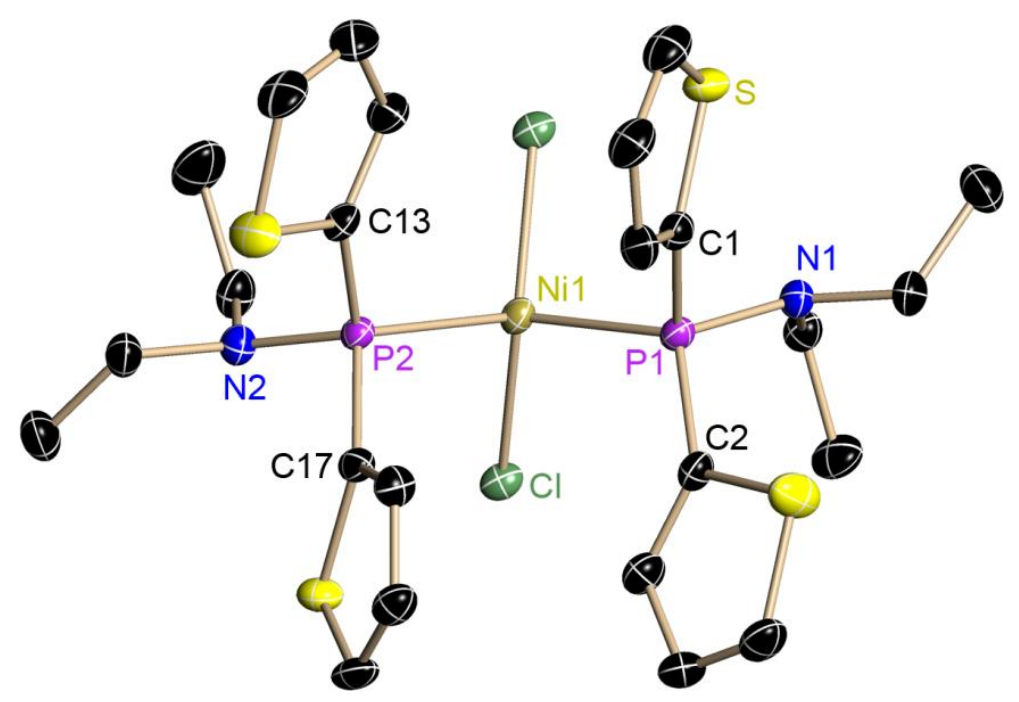

Figure 3-2. Molecular structure of 13. Anisotropic displacement parameters are depicted at the 50\% probability level. The toluene solvent molecule, the disorder of the thienyl moieties and chlorine/bromine and $\mathrm{H}$ atoms are omitted for clarity.

The P-Ni bond lengths in $\mathbf{1 3}$ (av. 2.3105(9) $\AA$ ) are in the range the P-Ni bond lengths of similar compounds, e.g. $\left[\left(\mathrm{Ph}_{3} \mathrm{P}\right)_{2} \mathrm{NiCl}_{2}\right](2.3180(2) \AA)^{[105]}$ and above the average Ni-P distance found in the CSD (Figure 3-3). ${ }^{[106]}$

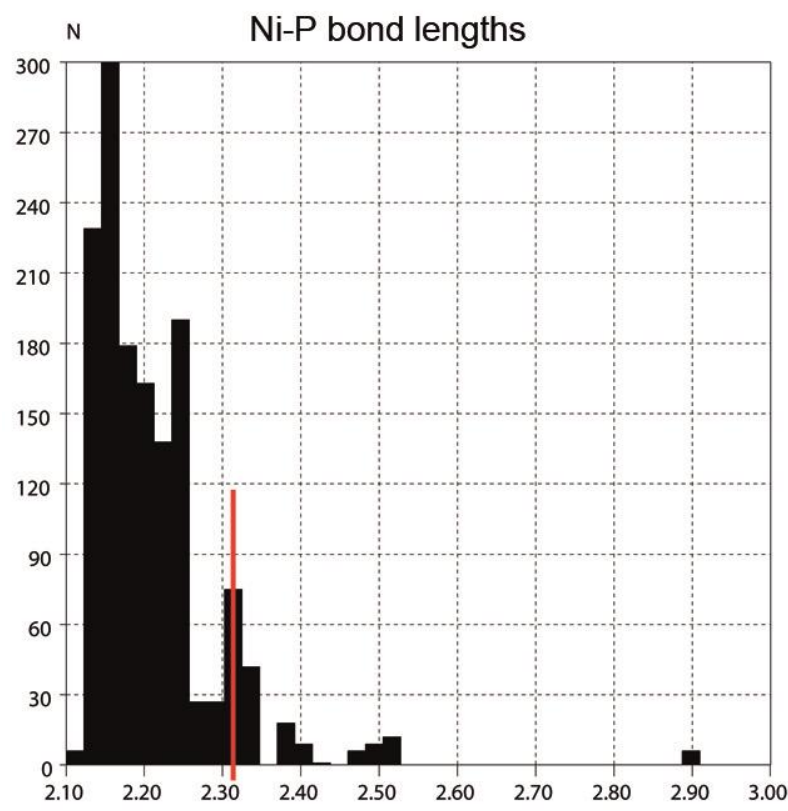

Figure 3-3. Bond length found in the $\mathrm{CSD}\left(\mathrm{P}_{2}-\mathrm{Ni}-\mathrm{Cl}_{2}\right.$ fragments).

The P-C distances (av. 1.797(3) $\AA$ ) as well as the P-N bond lengths (1.666(2) $\AA$ ) in 13 are in the expected range. The P1-Ni1-P2 angle is 105.64(3). The angles at the carbon-phosphorus bond are $\mathrm{C}-\mathrm{P}-\mathrm{C} 103.04(13)^{\circ}$ and $\mathrm{C}-\mathrm{P}-\mathrm{N} 107.09(12)^{\circ}$. Therefore 
tetrahedral geometry indicates a s-character of the lone pair of the phosphorus atom. A short $\mathrm{P}-\mathrm{N}$ bond would support the $p$-character of the lone pair, but the $\mathrm{P}-\mathrm{N}$ distance, $1.666(2) \AA$, designates a single bond $(1.70 \AA$ ) instead of a P-N double bond (1.55 $)$.

Table 3-1. Selected bond lengths [̊̊] and angles [deg] of 13.

\begin{tabular}{llll}
\hline P1-Ni & $2.3096(9)$ & P1-Ni1-P2 & $105.64(3)$ \\
P2-Ni & $2.3114(9)$ & C1-P1-C5 & $103.03(13)$ \\
P1-C1 & $1.796(3)$ & C13-P2-C17 & $103.05(13)$ \\
P1-C5 & $1.800(3)$ & C1-P1-N1 & $103.62(12)$ \\
P1-C13 & $1.794(3)$ & C5-P1-N1 & $110.63(12)$ \\
P1-C17 & $1.799(5)$ & C13-P2-N2 & $111.13(12)$ \\
P1-N1 & $1.666(2)$ & C17-P2-N2 & $103.00(12)$ \\
P2-N2 & $1.665(2)$ & SOF C1/Br & $0.74 \& 74$ \\
\hline
\end{tabular}

\subsubsection{Copper(I) Complex of 12 (14)}

Phosphane coordinated copper complexes are widely applied in many fields of inorganic and organic synthesis, e.g. the 1,4-reduction of enones. ${ }^{[36]}$ The soft copper(I) ion could be coordinated by a phosphorus atom ${ }^{[107]}$ or, for example, by the soft sulfur atom of thiophene ${ }^{[99 a, 104 c, 108]}$. Therefore $\mathbf{1 2}$ is a potential ligand to coordinate copper(I) ions either via the phosphorus atom or the thiophene sulfur atom.

Before preparation of a copper(I) complex of 12, the $\mathrm{Cu}(\mathrm{I})$ species $\left[\left(\mathrm{PPh}_{3}\right)_{2} \mathrm{Cu}\left(\mathrm{BH}_{4}\right)\right]$ was synthesized as reported in literature. ${ }^{[109]}\left[\left(\mathrm{PPh}_{3}\right)_{2} \mathrm{Cu}\left(\mathrm{BH}_{4}\right)\right]$ was dissolved in toluene at room temperature and $\mathbf{1 2}$ was added with the aim of a ligand exchange resulting in the complex shown in Scheme 3-5, but crystallisation attempts were inconclusive until now.

$$
\begin{aligned}
& { }_{\text {thi }} \stackrel{\mathrm{NEt}^{1}}{\mathrm{P}_{\bigcup_{\text {thi }}}}+\left[\left(\mathrm{PPh}_{3}\right)_{2}\left(\mathrm{Cu}\left(\mathrm{BH}_{4}\right)\right] \longrightarrow\left[\left(\mathrm{Pthi}_{2} \mathrm{NEt}_{2}\right)_{2} \mathrm{Cu}\left(\mathrm{BH}_{4}\right)\right]\right. \\
& \text { Scheme 3-5. Reaction scheme of } \mathbf{1 2} \text { with }\left[\left(\mathrm{PPh}_{3}\right)_{2} \mathrm{Cu}\left(\mathrm{BH}_{4}\right)\right] \text {. }
\end{aligned}
$$

Therefore, in a second attempt, copper(I) chloride was dissolved in acetonitrile and 12 was added. The reaction mixture was stirred until the solids were dissolved and stored in the freezer. After storage at $-20{ }^{\circ} \mathrm{C}$ for one week colourless crystals suitable 
for XRD experiments were formed. The copper(I) complex 14 crystallizes in the trinclinic space group $P \overline{1}$, the asymmetric unit contains one complex. The two copper and two $\mu$-bridging halogen atoms form a $\mathrm{Cu}_{2} \mathrm{X}_{2}(\mathrm{X}=\mathrm{Cl}, \mathrm{Br})$ four-membered ring. ${ }^{[110]}$ Both copper atoms are tetrahedrally coordinated by the phosphorus atom of 12, a nitrogen atom of an acetonitrile molecule and the $\mu$-bridging chlorine atoms, respectively. The copper atoms in $\mathbf{1 4}$ show no interaction (shortest $\mathrm{Cu} \cdots \mathrm{S} 4.853(3) \AA$ ) with the sulfur atoms of the thienyl side arms.

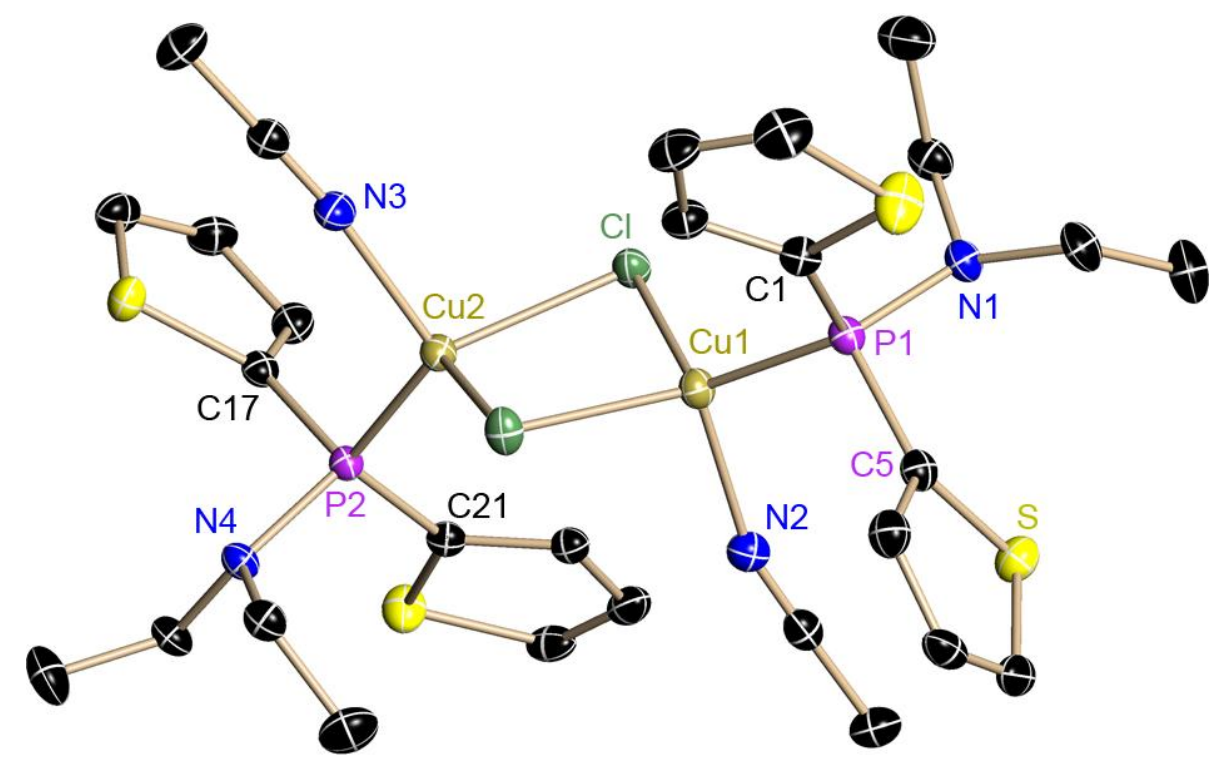

Figure 3-4. Molecular structure of 14. Anisotropic displacement parameters are depicted at the 50\% probability level. The disorder of the thienyl moieties and $\mathrm{H}$ atoms are omitted for clarity.

The $\mathrm{P}-\mathrm{Cu}$ bond lengths (av. 2.2030(9) $\AA$ ) are similar to those found in $\left[\left(\mathrm{Ph}_{3} \mathrm{P}\right) \mathrm{CuCl}(\mathrm{NCMe})\right]_{2}(2.172(1) \AA)^{[110 \mathrm{~b}]}$ and in accordance with the mean values for all published $\mathrm{Cu}-\mathrm{P}$ bond lengths $(2.257 \AA)$ in the CSD. A comparison of the $\mathrm{P}-\mathrm{C}$ bond length in $\mathbf{1 3}$ (av. 1.797(3) $\AA$ ) to those in $\mathbf{1 4}$ (av. 1.809(2) $\AA$ showed no differences within the triple standard uncertainties, whereas the $\mathrm{P}-\mathrm{N}$ distance is slightly elongated by $\sim 0.02 \AA$. This is an indication of a minor influence of the metal to the ligand. The acetonitrile ligands are 2.062(2) and 2.013(2) $\mathrm{A}$, away from $\mathrm{Cu} 1$ and $\mathrm{Cu} 2$, respectively (averaged values from a CSD search: av. $\mathrm{Cu}-\mathrm{N}_{\mathrm{NCMe}} 2.046 \AA$ ). The angles around the phosphorus atoms show a tetrahedral geometry similar to $\mathbf{1 3}$ (av. C-P-C 101.05(11) ${ }^{\circ}$ and $\left.\mathrm{C}-\mathrm{P}-\mathrm{N} 105.93(11)^{\circ}\right)$. Selected bond lengths and angles of the copper(I) complex (14) are summarized in Table 3-2 (averaged values in Table 3-5). 
Table 3-2. Selected bond lengths $[\AA]$ and angles [deg] of $\mathbf{1 4}$.

\begin{tabular}{llll}
\hline & Average & & \\
\hline P1-Cu1 & $2.2041(9)$ & C1-P1-C5 & $102.07(11)$ \\
P2-Cu2 & $2.2020(9)$ & C17-P2-C21 & $100.04(11)$ \\
P1-C1 & $1.808(2)$ & C1-P1-N1 & $102.48(11)$ \\
P1-C5 & $1.814(2)$ & C5-P1-N1 & $109.07(11)$ \\
P2-C17 & $1.806(2)$ & C17-P2-N4 & $102.22(11)$ \\
P2-C21 & $1.811(2)$ & C21-P2-N4 & $109.95(11)$ \\
P1-N1 & $1.680(2)$ & P1-Cu1-N2 & $106.09(6)$ \\
P2-N4 & $1.682(2)$ & P2-Cu2-N3 & $111.56(7)$ \\
Cu1-N2 & $2.062(2)$ & SOF C1/Br & $97 \& 94$ \\
Cu2-N3 & $2.013(2)$ & & \\
\hline
\end{tabular}

\subsubsection{Palladium(II) Complexes of 12 (15) and (16)}

As mentioned in the introduction, palladium is salient among transition metals in organometallic catalysis. Thienyl substituted phosphanes, e.g. $\mathrm{Thi}_{3} \mathrm{P}$, in which the central phosphorus atom coordinates to the palladium are applied in palladium complexes. By replacing triphenylphosphane by thienyl substituted phosphanes, the outcome of a reaction can improved. ${ }^{[111]}$ Phosphorus free thiophene ligands stabilized palladium complexes are also catalytically active ${ }^{[12]}$, e.g. by promoting the isomerization of 1-hexene to internal hexenes (Figure 3-5, left). ${ }^{[113]}$ Besides catalysis thiophenes, polythiophenes, and thienyl containing phosphanes are applied in conducting polymers ${ }^{[27,114]}$ (right) as well as palladium based molecular magnets. ${ }^{[25]}$ In such molecules a coordination of the thienyl-S to palladium, is often reported.
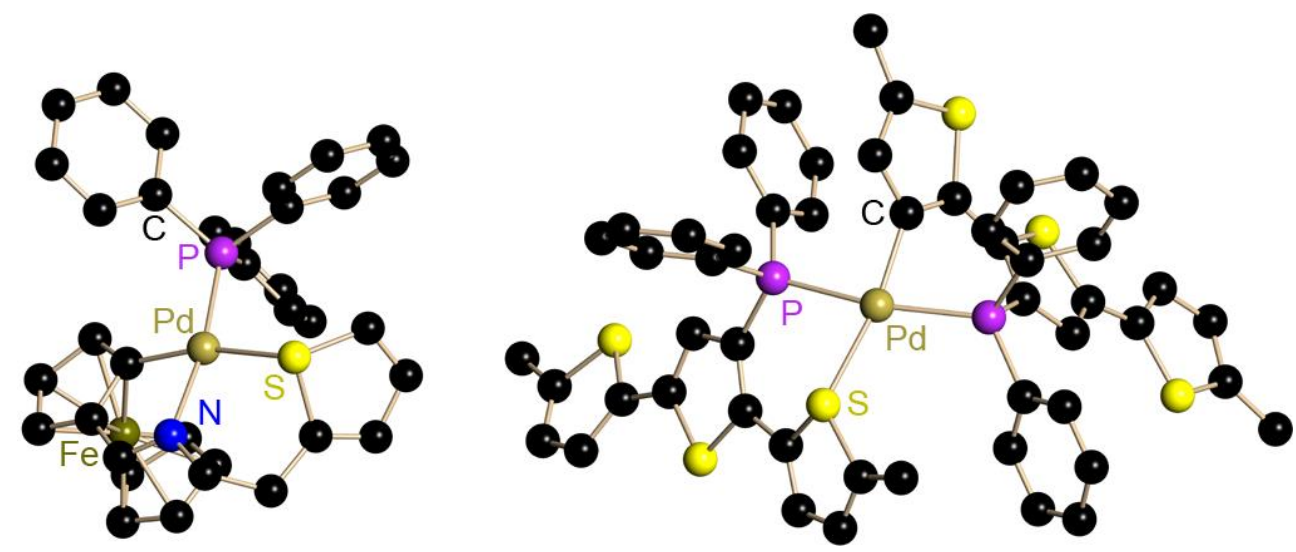

Figure 3-5. Example of a thienyl-S-Pd coordinated catalyst (left ${ }^{[12]}$ ) and polythienylphosphane ${ }^{[114]}$ (right) (counter ions omitted for clarity). 
The coordination of $\mathbf{1 2}$ to a palladium(II) species should be investigated and the results are presented within this chapter.

The reaction of 12 with $\left[\mathrm{PdCl}_{2} \cdot(\mathrm{PhCN})_{2}\right]$ in toluene at room temperature followed by storage at $-20{ }^{\circ} \mathrm{C}$ resulted in the formation of yellow crystals suitable for X-ray structural analysis. Two palladium complexes, i.e. 15 and 16, were obtained from reactions of different stoichiometries of $1: 2$ and 1:1 (metal : ligand) for $\mathbf{1 6}$ and $\mathbf{1 5}$, respectively. 15 is a mononuclear complex (Figure 3-6), whereas 16 forms a binuclear palladium species (Figure 3-7). The complex formation of a mononuclear or binuclear species can be tuned either by stoichiometry ${ }^{[15]}$ or by the choice of solvent. ${ }^{[16]}$ Nonpolar solvents favour the formation of mononuclear complexes, whereas polar solvents promote binuclear species.

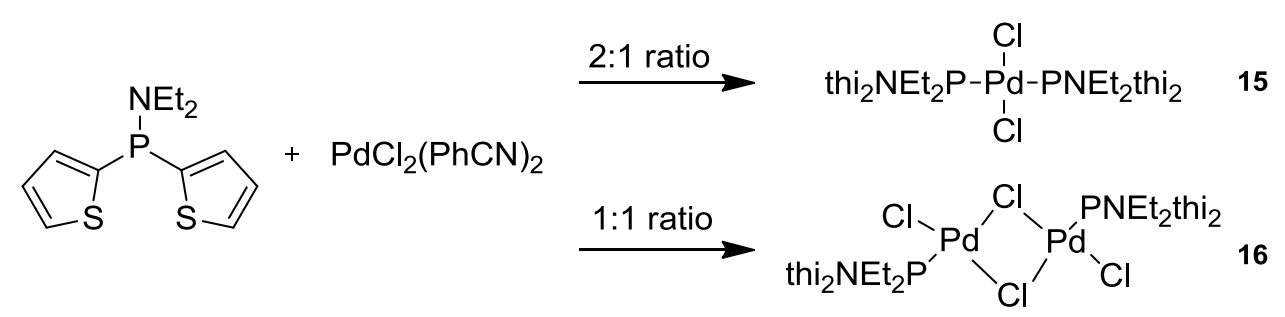

Scheme 3-6. Formation of mono- or binuclear Pd-complexes $\mathbf{1 5}$ and $\mathbf{1 6}$ via change of stoichiometry.

In both cases the palladium ions are square planar coordinated by halide atoms and the phosphorus atom of $\mathbf{1 2}$. The mononuclear complex $\mathbf{1 5}$ crystallizes as a nonmerohedral twin (BASF: 0.20) in the triclinic space group $P \overline{1}$ with four independent complex halves in the asymmetric unit. 


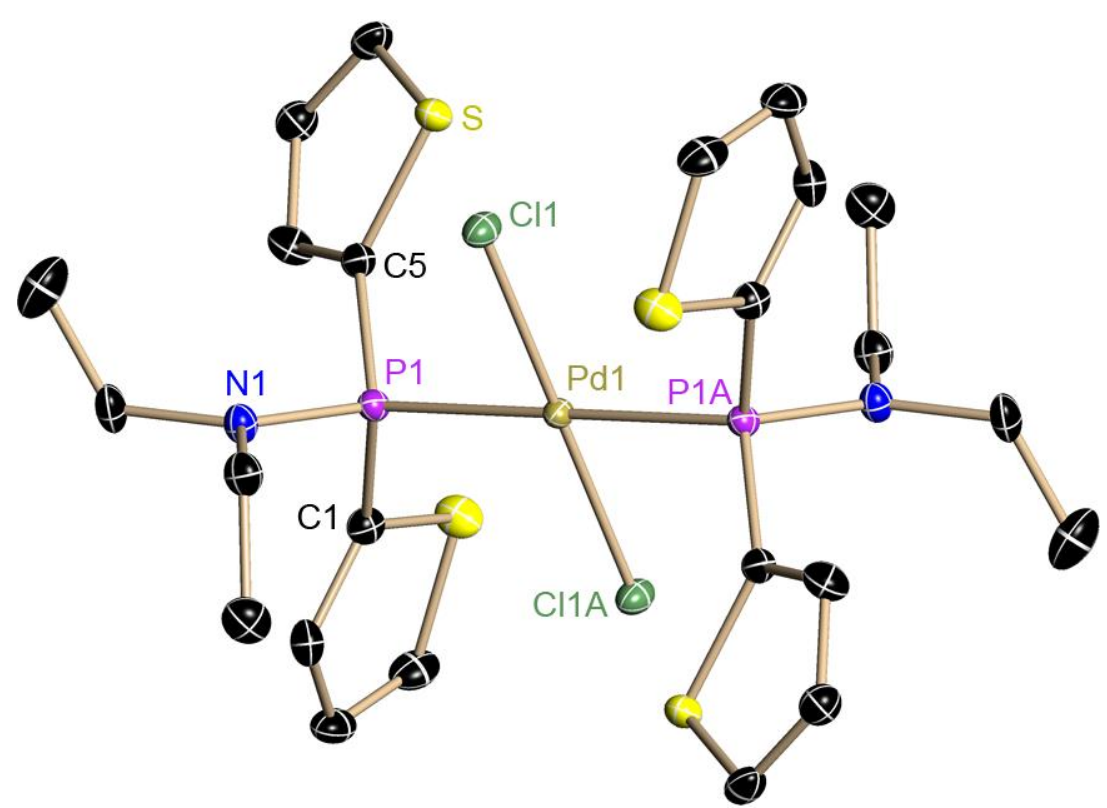

Figure 3-6. Molecular structure of 15. Anisotropic displacement parameters are depicted at the 50\% probability level. Disorder of the thienyl moieties and $\mathrm{H}$ atoms are omitted for clarity. Symmetry generated atoms labelled with $\mathrm{A}$.

The palladium atom in $\mathbf{1 5}$ shows a square planar coordination by the phosphorus atom of two 12 molecules and two halide atoms, each ligand pair in a mutually trans orientation. Similar to $\mathbf{1 3}$ and $\mathbf{1 4}$ the halide positions were occupied by chlorine and bromine, respectively. A strict separation and therefore positional refinement of both atoms was not possible. For the same reason the $\mathrm{M}-\mathrm{X}(\mathrm{X}=\mathrm{Cl}, \mathrm{Br})$ distances are not discussed. The average Pd-P bond length $(2.3363(7) \AA)$ of the four independent complexes fits well into the typical range of complexes of this kind, e.g. $\left.\left[\left((\text { thiPh })_{2}\right)_{2} \mathrm{P}\right)_{2} \mathrm{PCl}_{2}\right]^{[117]}$ (see Table 3-3). Average Pd-P bond length reported to the CSD for $\mathrm{P}-\mathrm{Pd}-\mathrm{P}$ fragments is $2.304 \AA$ and fits well to the found values in $\mathbf{1 5}$.

From the stoichiometric reaction of $\mathbf{1 2}$ with the palladium precursor crystals of $\mathbf{1 6}$ were obtained after storage at $-20^{\circ} \mathrm{C}$ for a few days. The binuclear palladium complex 16 crystallizes in the monoclinic space group $P 2_{1} / n$ with a half molecule in the asymmetric unit. A perspective view of the molecular structure is shown in Figure 3-7. The difference in the structural motif of $\mathbf{1 6}$ compared to 15 is the formation of a $\operatorname{Pd}_{2} \mathrm{X}_{2}$ four-membered ring. The palladium atoms are $\mu$-bridged by two halide atoms and the square-planar geometry around each is completed by a halide atom and the phosphorus atom of $\mathbf{1 2}$, respectively. 


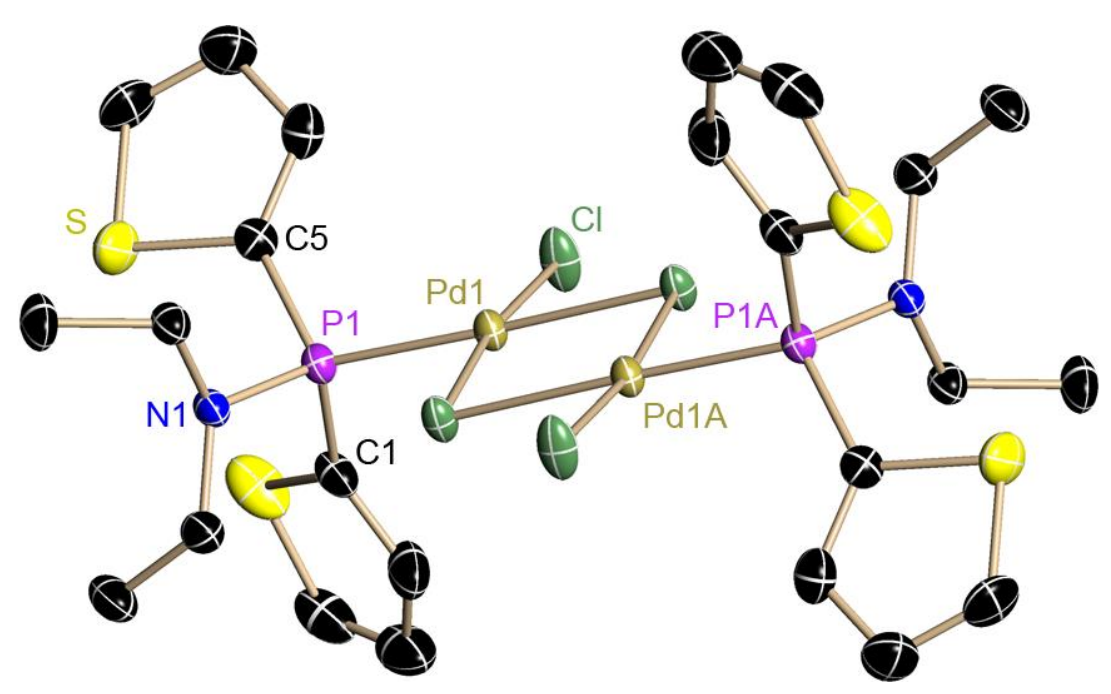

Figure 3-7. Molecular structure of 16. Anisotropic displacement parameters are depicted at the 50\% probability level. The solvent molecule toluene, disorder of the thienyl moieties and $\mathrm{H}$ atoms are omitted for clarity.

The Pd-P bond length of 2.2078(8) $\AA$ is comparable to the P-Pd distance $(2.215(1)$ $\AA$ ) found in $\left[\left\{\left(\mathrm{C}_{4} \mathrm{H}_{8} \mathrm{ON}\right) \mathrm{Ph}_{2} \mathrm{P}\right\}_{2} \mathrm{Pd}_{2} \mathrm{Cl}_{2}\left(\mu-\mathrm{Cl}_{2}\right)\right]^{[118]}$ (Figure 3-8), in which the central phosphorus atom is also coordinated by two aryl carbons and an amine nitrogen atom. The Pd-P bond length in 16 is significantly shorter $(\sim 0.13 \AA)$ compared to $\mathbf{1 5}$. This could be explained by diminishment of the electron density of the palladium due to the three electron withdrawing halide atoms. This bond shortage could also be seen in the P-C bond lengths P1-C1 1.780(3) $\AA$ and P1-C5 1.784(3) $\AA$ which are slightly shorter compared to $\mathbf{1 5}(\sim 0.02 \AA)$.

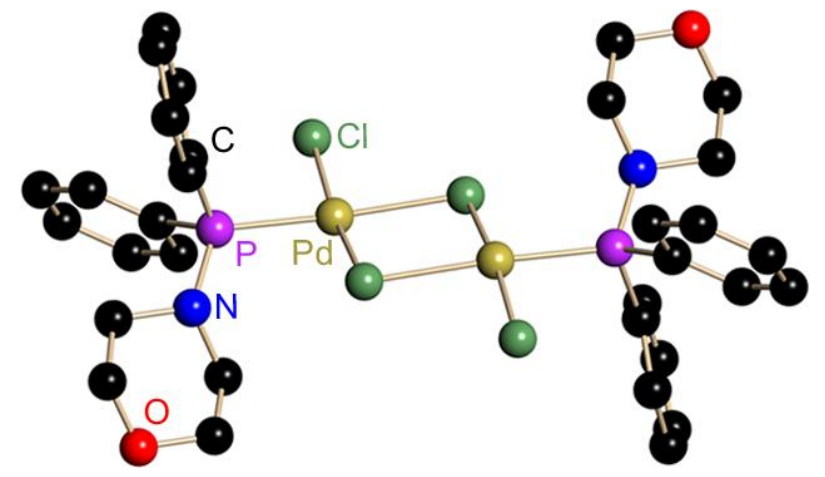

Figure 3-8. Molecular structure of $\left[\left\{\left(\mathrm{C}_{4} \mathrm{H}_{8} \mathrm{ON}\right) \mathrm{Ph}_{2} \mathrm{P}\right\}_{2} \mathrm{Pd}_{2} \mathrm{Cl}_{2}\left(\mu-\mathrm{Cl}_{2}\right)\right] .{ }^{[118]}$

A comparison of the molecular structures determined by single crystal XRDexperiments showed an accordance of the properties to similar structures in the 
literature. A remarkable difference between $\mathbf{1 5}$ and $\mathbf{1 6}$ is the Pd-P distance shortage in 16.

Table 3-3. Selected bond lengths $[\AA]$ and angles [deg] of 15, $\mathbf{1 6}$ and monomer, dimer.

\begin{tabular}{lllll}
\hline & $\mathbf{1 5}$ & $\mathbf{1 6}$ & monomer $^{[117]}$ & dimer $^{[118]}$ \\
\hline P-Pd & $2.3363(7)$ & $2.2078(8)$ & $2.3387(11)$ & $2.215(1)$ \\
P-C & $1.8064(2)$ & $1.782(3)$ & $1.8193(7)$ & $1.806(3)$ \\
P-N & $1.658(2)$ & $1.660(2)$ & - & $1.676(3)$ \\
C-P-C & $99.73(10)$ & $107.97(13)$ & $105.50(3)$ & 108.12 \\
C-P-N & $107.12(10)$ & $103.88(12)$ & & 105.88 \\
Pd-P-N & & & & $113.46(9)$ \\
SOF Cl/Br & $91 / 88 / 85 / 90$ & $90 \& 96$ & & - \\
\hline
\end{tabular}

\subsubsection{Iridium(I) Complex of 12 (17)}

The most prominent field of iridium complexes is the wide application as catalysts in hydrogenation reactions. Among these catalysts, a variety of phosphorus based ligands can be found. ${ }^{[119]}$ Recently $P, N, P$-pincer complexes of iridium entered the flourishing field of nitrogen formation and nitrogen fixation. ${ }^{[37 \mathrm{f}]}$

Single crystals of the iridium complex 17 were obtained by the same procedure as for 13-16 using $[\operatorname{IrCl}(\mathrm{COD})]_{2}$ as an iridium precursor. 17 crystallizes in the triclinic space group $P \overline{1}$ with the whole complex in the asymmetric unit (Figure 3-9). In the mono nuclear complex the iridium(I) atom is coordinated by the phosphorus atom of $\mathbf{1 2}$, a halide and the cyclooctadiene (COD) ligand. 


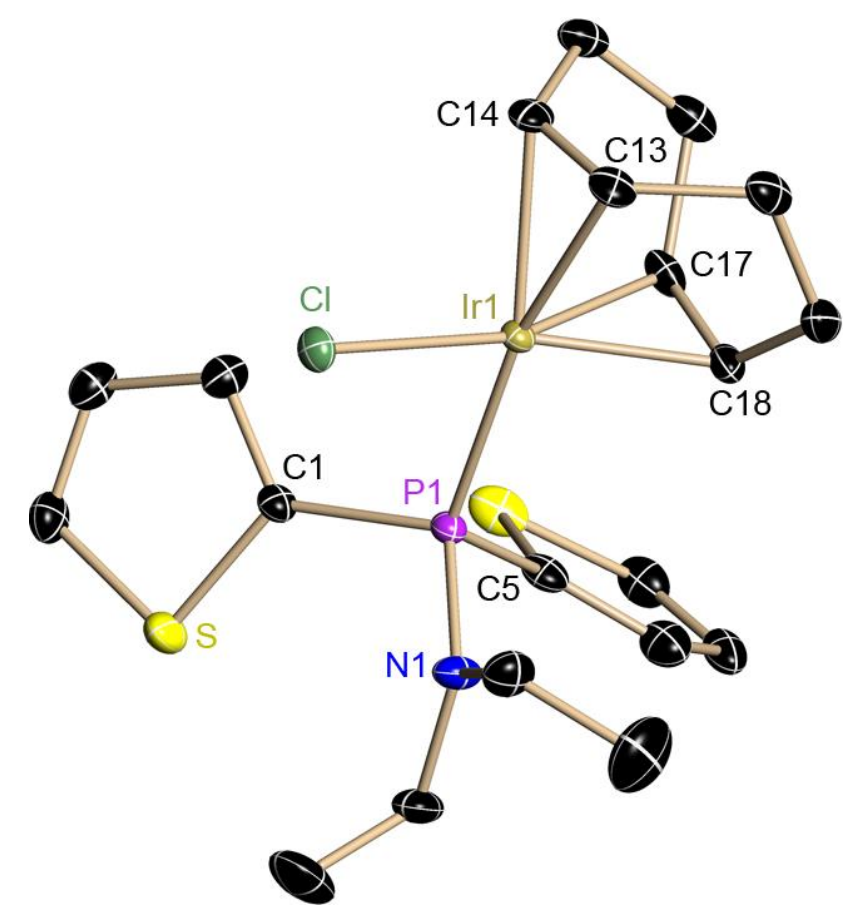

Figure 3-9. Molecular structure of 17. Anisotropic displacement parameters are depicted at the 50\% probability level. The solvent molecule toluene, disorder of the thienyl moieties and $\mathrm{H}$ atoms are omitted for clarity.

Both double bonds of the COD moiety coordinate to the iridium atom. The Ir-C distances to the corresponding carbon atoms are Ir1-C13 2.222(3) $\AA$, Ir1-C14

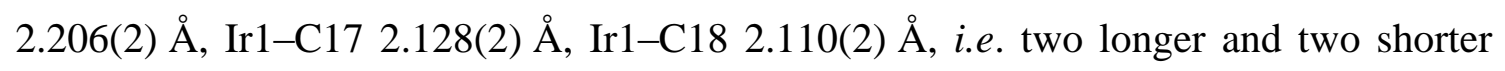
bonds are present, leading to Ir bond center distance of 2.214(3) $\AA$ and 2.119(2) $\AA$, respectively. A search in the CSD showed that these values are in the range of other IrCOD complexes (Ir-C $2.179 \AA$ ).

Similar to the other complexes a positional disorder of the halide ion occurs (SOF: 76:24 / Cl:Br). The mass spectrometry analysis of 17 confirms the presence of both atoms [m/z: 605.0 for chloride and 649.0 for bromine), but unfortunately, the $\mathrm{Cl}: \mathrm{Br}$ ratio could not be determined. Similar to the previous mentioned complexes 13-16, the two thienyl rings show no preference towards the $\operatorname{Ir}(\mathrm{I})$ atom. Remarkably, only one of the rings showed the typical rotational disorder (SOF: 55:45), whereas the other sulfur atom (S1) points away from the iridium ion. 
Table 3-4. Selected bond lengths $[\AA]$ and angles [deg] of $\mathbf{1 7 .}$

\begin{tabular}{llll}
\hline & & & \\
\hline P1-Ir1 & $2.2893(7)$ & C1-P1-C5 & $101.6(5)$ \\
P1-C1 & $1.816(2)$ & C1-P1-N1 & $110.72(9)$ \\
P1-C5 & $1.803(10)$ & C5-P1-N1 & $101.4(6)$ \\
P1-N1 & $1.6592(18)$ & SOF C1/Br & 76 \\
Ir1-C13 & $2.222(2)$ & & \\
Ir1-C14 & $2.206(2)$ & & \\
Ir1-C17 & $2.128(2)$ & & \\
Ir1-C18 & $2.110(2)$ & & \\
\hline
\end{tabular}

Going from nickel(II) via copper(I) and palladium(II) to the softer iridium(I) only a coordination of the phosphorus atom is observed. None of these late transition metals showed any interaction towards the thienyl-S atoms of 12. The reason for the apparent absence of M-S interaction is most likely not that the donor capacity of sulfur much weaker compared to that of phosphorus. Instead it is probably due to the pre-orientation of the phosphorus and due to the fact that formation of a four-membered metallacycle is required for a $P, S$-coordination to take place (See also Scheme 3-7).

\subsubsection{Gold(I) Complex of 12 (18)}

Since the last decade gold came into focus of chemistry as a versatile and powerful noble metal catalyst in organic synthesis. The active catalyst is often coordinated by a phosphane ligand ${ }^{[120]}$ and is for example used in the oxidative oxyarylation of alkenes. $^{[121]}$

Furthermore support thienylphosphane-gold interactions the electronic properties in conducting polymers. ${ }^{[122]}$

The gold complex 18 was prepared according to the general scheme using $\mathrm{AuCl}\left(\mathrm{SMe}_{2}\right)$ as gold(I) precursor. It crystallizes in the monoclinic space group $P 2_{1} / c$ with one molecule in the asymmetric unit. 


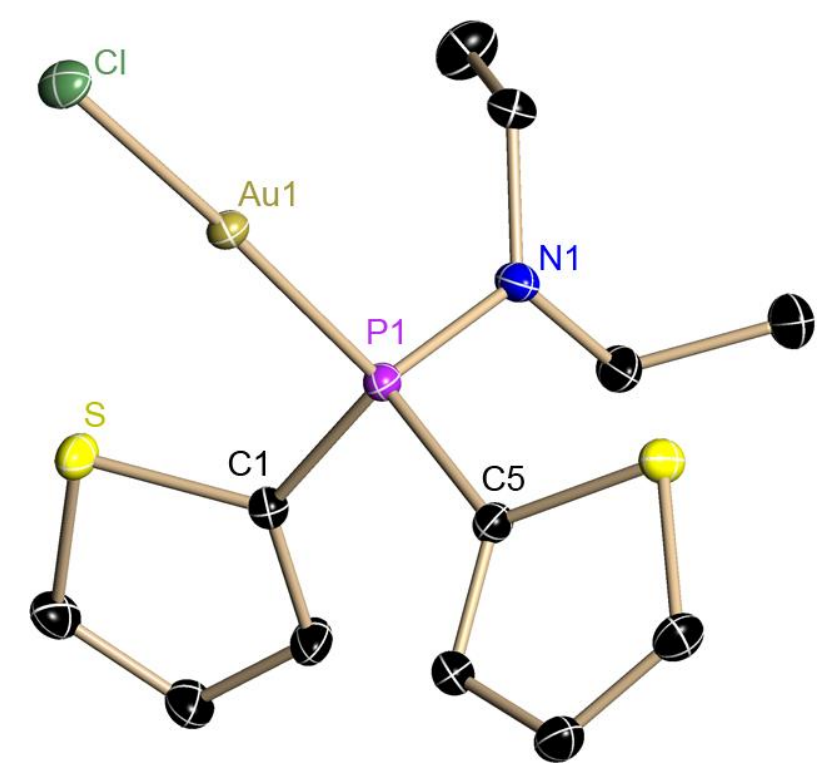

Figure 3-10. Molecular structure of 18. Anisotropic displacement parameters are depicted at the 50\% probability level. The disorder of the thienyl moieties and $\mathrm{H}$ atoms are omitted for clarity.

The gold atom is coordinated by a halide atom and the phosphorus atom of $\mathbf{1 2}$ in a linear fashion $\left(\mathrm{P}-\mathrm{Au}-\mathrm{Cl} 176.89(3)^{\circ}\right)$ widely known for phosphane-gold-halogen complexes (Figure 3-13). ${ }^{[122-123]}$ The $\mathrm{P}-\mathrm{Au}$ distance is 2.2331(6) $\AA$ and within the range of $\mathrm{R}_{3} \mathrm{P}-\mathrm{Au}$ bond lengths found in the CSD (P-Au av. 2.261 $\mathrm{A}$ ). The thienyl moieties show positional disorder (both site occupation factors refine to 0.92) due to a rotation along the C-P bond. Therefore, the sulfur atoms do not show any preferred orientation and no Au-S interaction can be observed (shortest distance $3.574 \AA$ ). The gold atoms of neighbouring complexes show no aurophilic interactions ${ }^{[124]}$ as found in numerous gold(I) compounds ${ }^{[125]}$. The distance between two adjacent gold atoms is $>5 \AA$ and therefore too large for $\mathrm{Au}-\mathrm{Au}$ interaction to be present.

\subsubsection{Summary}

In Table 3-5 the average bond lengths and angles of the bis(2-thienyl)diethylaminophosphane complexes 13-18 are summarized. A comparison of the bond length and angles revealed only small differences on the donor properties of $\mathbf{1 2}$ towards these selected late transition metals. The $\mathrm{P}-\mathrm{M}$ distances are in the expected range and a coordination of the thienyl sulfur atoms was not observed in any of the compounds. 
Table 3-5.Summary of averaged bond lengths $\left[\AA\right.$ ) and angles $\left[{ }^{\circ}\right]$ in $\mathbf{1 3 - 1 8}$.

\begin{tabular}{lllllll}
\hline \multicolumn{1}{r}{ metal } & $\mathbf{1 3}$ & $\mathbf{1 4}$ & $\mathbf{1 5}$ & $\mathbf{1 6}$ & $\mathbf{1 7}$ & $\begin{array}{l}\mathbf{1 8} \\
\mathbf{A u}\end{array}$ \\
\hline $\mathbf{P}-\mathbf{M}$ & $2.3105(9)$ & $\mathbf{C u}$ & $\mathbf{P d}$ & $\mathbf{P d}$ & $\mathbf{I r}$ & $\mathbf{\text { Ad }}$ \\
$\mathbf{P}-\mathbf{C}$ & $1.7973(3)$ & $1.8098(2)$ & $1.8064(2)$ & $1.782(3)$ & $1.810(3)$ & $1.8010(13)$ \\
$\mathbf{P}-\mathbf{N}$ & $1.666(2)$ & $1.681(2)$ & $1.658(2)$ & $1.660(2)$ & $1.6529(2)$ & $1.6550(12)$ \\
$\mathbf{C}-\mathbf{P}-\mathbf{C}$ & $103.04(13)$ & $101.05(11)$ & $99.73(10)$ & $107.97(13)$ & $101.6(5)$ & $102.19(6)$ \\
$\mathbf{C}-\mathbf{P}-\mathbf{N}$ & $107.09(12)$ & $105.93(11)$ & $107.12(10)$ & $103.88(12)$ & $106.1(4)$ & $107.92(6)$ \\
$\mathbf{P} \mathbf{\Sigma}$ & 317.2 & 312.92 & 313.97 & 315.73 & 313.72 & 318.02 \\
$\mathbf{N} \boldsymbol{\Sigma}$ & 353.8 & 351.77 & 357.61 & 351.44 & 359.98 & 357.83 \\
$\mathbf{S O F}: \mathbf{C l} / \mathbf{B r}$ & $74 / 74$ & $97 / 94$ & $91 / 88 / 85 / 90$ & & & \\
\hline
\end{tabular}

Examples in literature showed, that the coordination of the thienyl-S atom to late transition metals, e.g. nickel(II), copper(I), palladium(II), iridium(I), and gold(I), is feasible and promising for further investigation. A main reason for the noncoordination, besides the stronger donor capacity of phosphorus, could be the missing pre-coordination of the sulfur atom. The insertion of a linker, e.g. a $\mathrm{CH}_{2}$-group, between the phosphorus atom and the thienyl moiety would led to an enlargement of the biteangle whereby a $P, S$-coordination would become more likely (Scheme 3-7). ${ }^{[126]}$ The thus formed five-membered metallacycles are less strained than the four-membered rings without a linker.

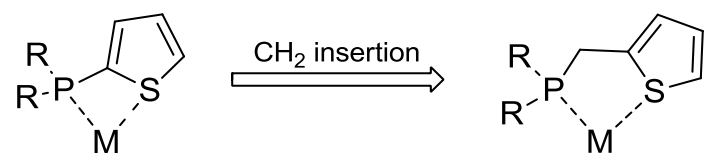

Scheme 3-7. Insertion of a $\mathrm{CH}_{2}$-group between phosphorus and thienyl moiety (left: four-membered ring; right: five-membered ring).

Furthermore a phosphanide ligand of $\mathbf{1 2}$ is imaginable to obtain a promising $P, S$ Janus head ligand. Therefore $\mathbf{1 2}$ has to be transformed into the bis(2-thienyl)phosphane via the chlorophosphane. The preliminary results on this are presented in the next chapter. 


\subsection{Reduction to Dithienylphosphane (19)}

The preparation of bis(2-thienyl)chlorophosphane (20), starting from 12, was performed according to the published method. ${ }^{[101]}$ After filtration of the crude product through Celite and removal of $n$-pentane, 20 was obtained in high yields. Remarkably, the formed crystals were suitable for single crystal X-ray analysis, although a structural elucidation had not previously been performed.

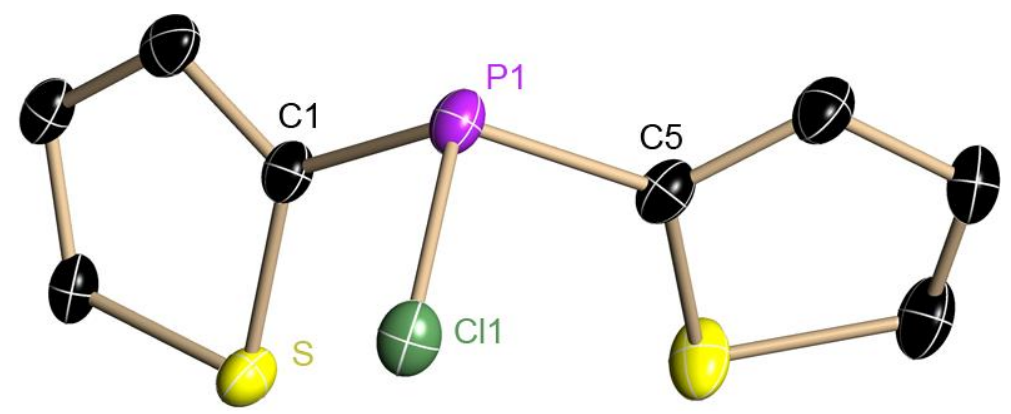

Figure 3-11. Molecular structure of 20. Anisotropic displacement parameters are depicted at the 50\% probability level. Hydrogen atoms and disorder of the thienyl rings are omitted.

Bis(thienyl)chlorophosphane (20) crystallizes in the orthorhombic space group $F d d 2$ with two independent molecules in the asymmetric unit. The thienyl groups are rotationally disordered similar to the 2-thienyllithium molecules 13-18 (vide supra). The $\mathrm{P}-\mathrm{Cl}$ distance in $\mathbf{2 0}$ is 2.10(4) $\AA$ and in good accordance with the bond lengths reported in literature (2.04 $\AA$ from gas phase calculations; ${ }^{[127]}$ and $2.055-2.071 \AA$ in the solid state (CSD)). The influence of different aromatic substituents on the $\mathrm{P}-\mathrm{Cl}$ bond length in phosphanes is shown in Table 3-6. Electron-rich aromatic systems like the thienyl substituents in 20 strengthen and shorten the $\mathrm{P}-\mathrm{C}_{\mathrm{ipso}}$ bond, which on the other hand weakens the $\mathrm{P}-\mathrm{Cl}$ bond and cause the elongation. This may be an explanation for the slightly longer bond length $\left(+0.02 \AA\right.$ ) compared to $\mathrm{Ph}_{2} \mathrm{PCl}$ (gas phase calculation) ${ }^{[128]}$. When electron withdrawing groups, e.g. $-\mathrm{CF}_{3}$, are attached to the phenyl substituents the $\mathrm{P}-\mathrm{Cl}$ bond length is shortened (see the Ar' $\mathrm{Ar}$ ' $\mathrm{PCl}$ and $\mathrm{Ar}_{2} \mathrm{PCl}$ columns in Table 3-6) to 2.0619(9) $\AA$ and 2.061(1) $\AA$, respectively, thus elongated by $0.05 \AA$ compared to the bond in $\mathbf{2 0}$. 
Table 3-6. Selected bond lengths [ $\AA$ ] and angles [deg] of 17.

\begin{tabular}{lllll}
\hline & $\mathbf{2 0}$ & $\mathbf{P h}_{2} \mathbf{P C l}^{[128]}$ & $\mathbf{A r}^{\prime} \mathbf{A r} \mathbf{P C l}^{[129]}$ & $\mathbf{A r}_{2} \mathbf{P C l}^{[130]}$ \\
\hline $\mathbf{P}-\mathbf{C l}$ & $2.1051(14)$ & $2.086(1)$ & $2.061(1)$ & $2.0619(9)$ \\
$\mathbf{P}-\mathbf{C}$ & 1.8025 & $1.827(1)$ & $1.873(1)$ & $1.856(2)$ \\
Cl-P-C & $99.43(13)$ & 102.5 & $104.73(6)$ & $99.17(7)$ \\
C-P-C & $105.90(16)$ & 99.7 & $102.10(9)$ & $100.37(10)$ \\
T [K] & 100 & 433 & & 150 \\
\hline
\end{tabular}

Another structural feature of $\mathbf{2 0}$ is the torsion of the thienyl substituents. The torsion angle is calculated to be $55.0(3)^{\circ}$ for C5-P1-C1-S1 and -28.6(3) for C1-P1-C5-S2 and sums up to 26.4(6). The ${ }^{31} \mathrm{P}$ NMR signal of $20\left(\delta 53.4 \mathrm{ppm}\right.$ in $\left.\mathrm{C}_{6} \mathrm{D}_{6}\right)$ with the electron rich thienyl substituents is shifted to higher field compared to $\mathrm{Ph}_{2} \mathrm{PCl}(\delta 120 \mathrm{ppm}) .{ }^{[131]}$

The isolated bis(2-thienyl)chlorophosphane (20) is sensitive to moisture and air. Although the preparation of NMR samples of the isolated $\mathbf{2 0}$ has been performed under inert atmosphere, oxidation took place and decomposition was observed. It was assured by ${ }^{31} \mathrm{P}$ NMR of the reaction mixture that the oxidation did not occur during the conversion. In comparison with the literature values it was assumed that the observed signals ( $\delta 22.35$ ppm and 20.88 ppm in $\left.\mathrm{C}_{6} \mathrm{D}_{6}\right)$ in the ${ }^{31} \mathrm{P}$ NMR spectrum of 20 belong to the oxidized phosphanes shown in Scheme 3-8, only detected after the workup, therefore effectively distinguished as oxidation source. ${ }^{[132]}$

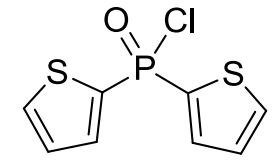

${ }^{31} \mathrm{P}$ NMR: $\quad \delta 14.3\left(\mathrm{CD}_{3} \mathrm{OD}\right)$<smiles>O=P(O)(c1cccs1)c1cccs1</smiles>

22

$\delta 23.8\left(\mathrm{CDCl}_{3}\right)$

Scheme 3-8. Possible oxidation products of 20 and ${ }^{31} \mathrm{P}$ NMR shift.

The reduction of $\mathbf{2 0}$ with $\mathrm{LiAlH}_{4}$ was just recently published. ${ }^{[100]}$ A reduction with $\mathrm{KHB} t \mathrm{Bu}_{3}$ is mentioned in the article as well, but no further details were given therein. Within this thesis different reducing agents were used to obtain 19. K-selectrid $\left(\mathrm{KHB} t \mathrm{Bu}_{3}\right)$, diisobutlyaluminium hydride (DIBAL) and lithium borohydride $\left(\mathrm{LiBH}_{4}\right)$ (listed in order of increasing reduction strength) ${ }^{[133]}$ were tested to reduce 20 to 19 (Scheme 3-9). 


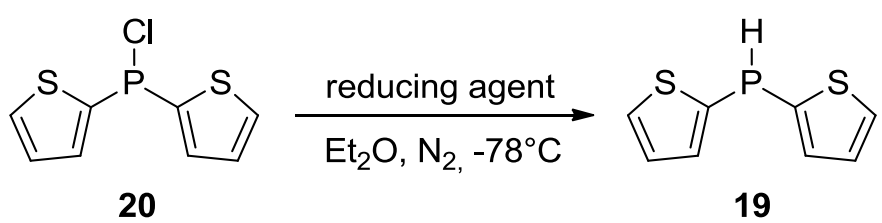

Scheme 3-9. Reduction scheme.

Different preparations have been conducted. The dropwise addition of K-selectride or DIBAL led to a product mixture of 19 and tetra(2-thienyl)diphosphane ((2-thienyl $\left.)_{4} \mathrm{P}_{2}\right)$ 21. The addition of $\mathrm{LiBH}_{4}$ in one portion led to phase pure $\mathbf{1 9}$, confirmed by a ${ }^{31} \mathrm{P}$ NMR spectrum of the reaction mixture, unfortunately, however, the work up only led to decomposition products. Further approaches were conducted with DIBAL and K-selectride which led to mutually identical results. Therefore, further attempts were not carried out with K-selectride, due to the comparable results to DIBAL. For both DIBAL and K-selctride only one product was quantitatively obtained. The ${ }^{31} \mathrm{P}$ NMR spectrum showed only one signal ( $\left.\delta-38.7 \mathrm{ppm}\right)$ and the proton decoupled ${ }^{31} \mathrm{P}$ NMR spectrum also showed a singlet. The mass spectra revealed the obtained product to be tetra(2-thienyl)diphosphane (m/z 393.9) formed through phosphane coupling. Single crystals of tetra(2-thienyl)diphosphane were isolated and a cell parameter comparison confirmed the previously reported structure. ${ }^{[100]}$ The reaction setup was changed to avoid the formation of the diphosphane. A solution of DIBAL in diethyl ether was prepared to have a reductive milieu and $\mathbf{2 0}$ was added dropwise. The resulting ${ }^{31} \mathrm{P}$ NMR spectrum showed a dublet at $\delta-90.6 \mathrm{ppm}\left(J_{\mathrm{H}-\mathrm{P}}=227.7 \mathrm{~Hz}\right)$ in accordance with the ${ }^{1} \mathrm{H}$ NMR spectrum displaying a dublet at $\delta 5.47 \mathrm{ppm}\left(J_{\mathrm{H}-}\right.$ $\mathrm{P}=227.7 \mathrm{~Hz}$ ). The mass spectrometry analysis ( $\mathrm{m} / \mathrm{z} 197.0)$ identified the main product to be $\mathrm{Thi}_{2} \mathrm{PH}(19)$ but phosphane coupling occurred as well in an est. ratio of 1:3. The high field shift of the ${ }^{31} \mathrm{P}$ NMR signal of 19 compared to diphenylphosphane $(\delta-41.1 \mathrm{ppm})^{[131]}$ could be explained by the electron richer thienyl substituents. These results are in accordance with the recently reported analytical data. ${ }^{[100]}$

It can be assumed that in the beginning of the reaction between 20 and DIBAL only 19 is formed, and no coupling takes place when $\mathbf{2 0}$ is added drop wise. At the end of the reaction the concentration of $\mathbf{1 9}$ rises and further addition of $\mathbf{2 0}$ lead to the unsolicited diphosphane. Furthermore it was observed that the vigorous stirring of the reaction mixture has a positive effect on the formation of 19. 
The results of this study with different reducing agents show that quantitative formation of 19 is supported by application of stronger reducing agents, i.e. $\mathrm{LiBH}_{4}$ or DIBAL. Furthermore the aqueous work up $^{[134]}$ led to the oxidized species 22. A distillation after removal of the precipitates, as reported ${ }^{[100]}$ should lead to higher yields. Primary distillations led to the decomposition of bis(2-thienyl)phosphane. Alternatively, it could be tested if it would be possible to solve the crude product in a nonpolar solvent, e.g. $n$-pentane, to precipitate and separate the formed salts and byproducts to purify the product.

Single crystals of bis(2-thienyl)phosphinic acid $\left(\operatorname{thi}_{2} \mathrm{P}(\mathrm{O}) \mathrm{OH}, 22\right)$ were grown immediately after work up. 22 crystallizes in the monoclinic space group $P 2_{1} / n$ with one molecule in the asymmetric unit. The molecules of $\mathbf{2 2}$ form a coordination chain via hydrogen bonding between the hydroxyl proton and the oxygen atom $(\mathrm{O} 2 \mathrm{~A})$ of an adjacent molecule (Figure 3-12). The position could be determined from the density difference map, and the O1-H1 bond length refined to 0.90(1) $\AA$ and the length of the hydrogen bonding $\mathrm{O} 1-\mathrm{H} \cdots \mathrm{O} 2 \mathrm{~A}$ to $1.61(3) \AA$. The $\mathrm{O} 1 \cdots \mathrm{O} 2 \mathrm{~A}$ distance of $2.51 \AA$ is within the range of an $\mathrm{O}-\mathrm{H} \cdots \mathrm{O}$ distance observed in $\mathrm{P}-\mathrm{O}$ containing molecules found in the CSD. The P1-O1 bond length is shortened to 1.5514(12) $\AA$ (lit.: $1.62 \AA^{[135]}$ ) and the P1O2 bond length is elongated to $1.4973(12) \AA$ (lit.: $1.47 \AA^{[135]}$ ), due to a weakening of the $\mathrm{O} 1-\mathrm{H} 1$ bonding and the formation of a hydrogen bonding between $\mathrm{H} 1$ and $\mathrm{O} 2 \mathrm{~A} .{ }^{[136]}$

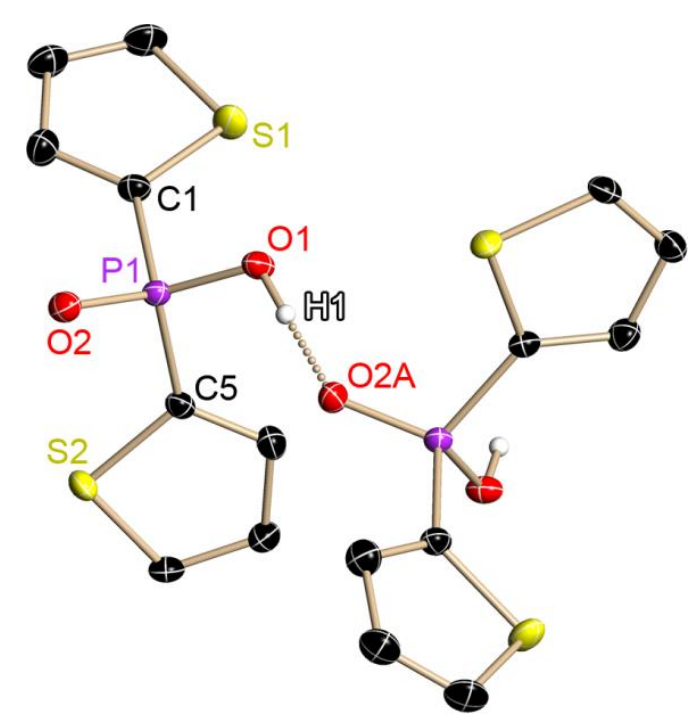

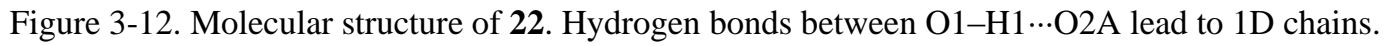
Anisotropic displacement parameters are depicted at the $50 \%$ probability level. Other hydrogen atoms and disorder of the thienyl moieties are omitted. Symmetry operation of O2A $(-x+3 / 2, y-1 / 2,-z+1 / 2)$. 
Remarkably, the rotational disorder along the $\mathrm{C}-\mathrm{P}$ vector of the thienyl groups is relatively small compared to the disorder in 13-18. The SOFs refined to 0.948 for the ring bearing $\mathrm{S} 1$ and 0.957 for the ring bearing S2, respectively. 


\subsection{Sidearm Engineering of P,S-Ligand Systems}

A further aim of this thesis was the extension and derivatisation of the phosphane ligands side arms. The insertion of a methylene bridge in the side chain of a fivemembered heterocyclic substituted phosphane would lead to a special kind of hemilabile ligand, so called Janus head ligand (Scheme 3-10).

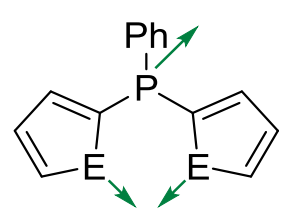

$E=O, S$

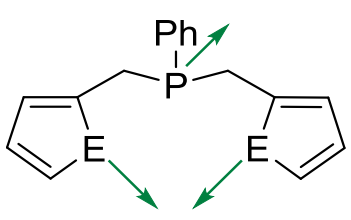

$E=O$

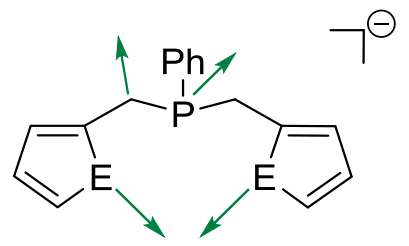

Scheme 3-10. Side chain elongation and donor sites of Janus head type methylene bridged fivemembered heterocyclic substituted phosphanes. Left: without methylene bridge, center: neutral methylene bridge, right: anionic ligand.

Janus head ligands are capable of coordinating metal atoms with donor sites pointing in opposite directions (examples are shown in Chapter 1.3.1).

Linder et al. introduced a synthesis of bisfurfurylphenylphosphane(Scheme 3-10 center). ${ }^{[137]}$ The reaction was carried out via a phosphonium salt and followed by a reduction with $\mathrm{LiAlH}_{4}$. The drawbacks of this strategy were the non-commercial starting materials, i.e. furfurylbromide or furfurylchloride.

Within this chapter the approach of a one-pot synthesis of bisfurfurylphenylphosphane will be presented. Some of the results presented in this chapter arose during the work of Jan Enno Gerkens under my guidance. The commercially available starting material furfuryl alcohol (2-furanmethanol) was chosen and transformed to the chloride. A possible reaction scheme to synthesize the Janus head ligand is shown in Scheme 3-11.

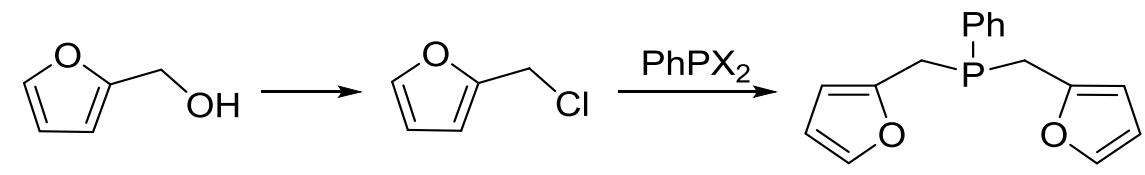

Scheme 3-11. Possible reaction path from the alcohol to bisfurfurylphenylphosphane.

An elegant way to chlorinate alcohols is the reaction with thionylchloride $\left(\mathrm{SOCl}_{2}\right)$ under ambient conditions. ${ }^{[138]}$ The gaseous side product $\mathrm{SO}_{2}$ can be easily removed and the 
evolving $\mathrm{HCl}$ can be caught by a base. The addition of a base is crucial to the reaction to avoid a ring opening of the acid sensitive furfuryl alcohol.

First reactions were carried out with triethylamine as a proton scavenger. Shortly after the addition of $\mathrm{SOCl}_{2}$, the reaction mixture turned from slightly blue to black. After removal of the salt and solvent the desired product could not be identified.

Akamanchi reported the usage of benzotriazole as base, due to its endothermic salt formation and the facile recycling via $\mathrm{NaOH}$ treatment after filtration. ${ }^{[139]}$ According to the article a stock solution of thionyl chloride and benzotriazole in dry DCM was prepared and slowly added to furfuryl alcohol in solution. The reaction mixture turned yellow and a precipitate was formed. After filtering and washing of the filtrate, as required according to the procedure, the precipitate turned brown. Again the furfuryl chloride could not be identified in the product mixture.

A closer look on the possible reaction mechanism of the chlorination may reveal the reason for the failure. A $S_{N} 2$ (Scheme 3-12, left pathway) or an internal nucleophilic substitution $\left(\mathrm{S}_{\mathrm{N}} \mathrm{i}\right)$ (right) is feasible.

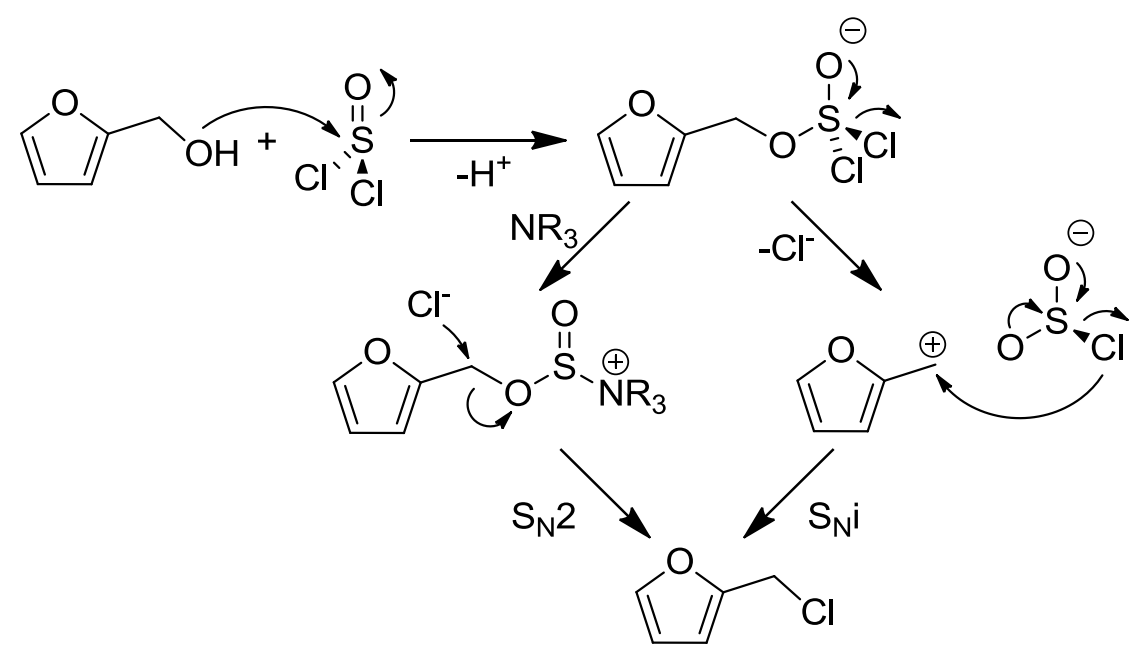

Scheme 3-12. Proposed $\mathrm{S}_{\mathrm{N}} \mathrm{i}$-reaction mechanism of the chlorination of furfuryl alcohol.

In the presence of a base, e.g. $\mathrm{Et}_{3} \mathrm{~N}$, the chlorination of the furfuryl alcohol could occur in a $S_{N} 2$-reaction mechanism. The reason for the failure of the reaction could be explained by the steric hindrance in the back attack of the chloride by the formed intermediate (Scheme 3-12, $\mathrm{S}_{\mathrm{N}} 2$-pathway). The drawback in the $\mathrm{S}_{\mathrm{N}} \mathrm{i}$-reaction mechanism could be explained by the formation of a carbocation. The instable primary carbocation could not be sufficiently stabilized by the heteroaromatic system of the 
furan moiety. This explanation is buoyed by the chlorination of the more aromatic 2thienyl-methanol under similar conditions. ${ }^{[140]}$

Furthermore the Appel-reaction ${ }^{[141]}$ was carried out to transform the furfuryl alcohol into a halide. ${ }^{[142]}$

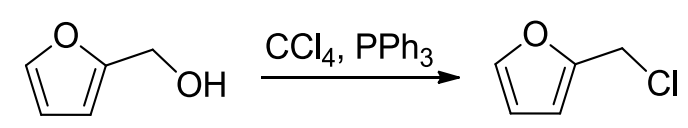

Scheme 3-13. Apple-reaction of furfuryl alcohol to furfuryl chloride. ${ }^{[142]}$

The equimolar consumption of $\mathrm{PPh}_{3}$ is a disadvantage of the Apple-reaction because of its apparent atom inefficiency. Moreover the high toxicity and the carcinogenic potential of $\mathrm{CCl}_{4}$ are the drawbacks of this reaction and milder conditions would have been preferred. Nevertheless, the furfuryl chloride could be isolated after distillation of the crude product in moderate yields.

The first ambitious attempts of the carbon-phosphorous coupling were carried out by an in situ dilithiation of phenylphosphane ${ }^{[134,143]}$ and the addition of furfuryl chloride (Scheme 3-14). Synthetic examples in literature showed, that the dilithiation of aryl substituted phosphanes is feasible, ${ }^{[134,143]}$ although the dimetallation to phosphinides is rather doubtful and almost impossible. ${ }^{[144]}$

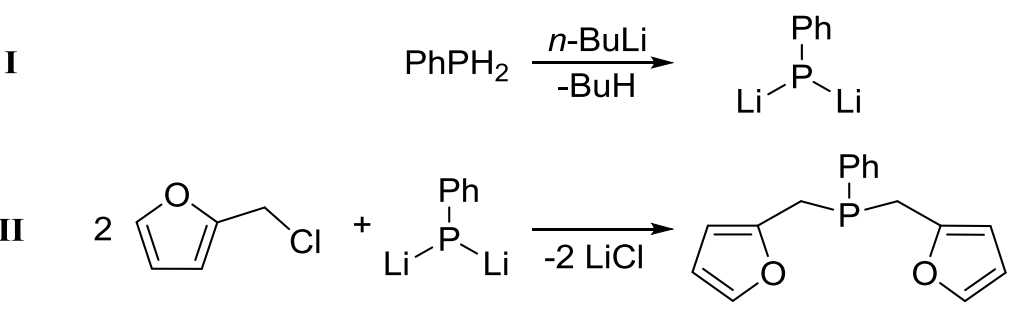

Scheme 3-14. In situ lithiation of $\mathrm{PhPH}_{2}$ (I) and the reaction with furfuryl chloride (II) to yield bisfurfurylphenylphosphane.

The reaction mixture was stirred for two hours and the precipitants were filtered off. After the removal of the volatile compounds the crude product was filtered again and a clear brownish liquid was obtained. The ${ }^{31} \mathrm{P}$ NMR spectrum of the crude product showed a signal at $\delta-23.90 \mathrm{ppm}$, which belongs, according to the literature, to bisfurfurylphenylphosphane, as well as further unidentified side products. ${ }^{[137]}$ The recommended work up by Lindner, to dissolve the crude product in hexane, filtration 
and recrystallization did not work as reported. Varying the solvent volume and cooling down to $-44^{\circ} \mathrm{C}$ did not improve the work up as well.

In further reactions to obtain bisfurfurylphenylphosphane, the reaction mixture was only filtered, the solvent removed, and the crude product was used for further reactions.

The mass spectrometrical analysis of the crude product showed that the oxidized product $(\mathrm{m} / \mathrm{z}=286)$ and a coupling product of the phosphane $(\mathrm{m} / \mathrm{z}=378)$ were formed. The coupling product, a diphosphane, could be formed since the lithiation did not occur in one step, as previously anticipated (shown in Scheme 3-14), but a single substituted phosphane rather reacted with the lithiated one to form the diphosphane (Scheme 3-15).

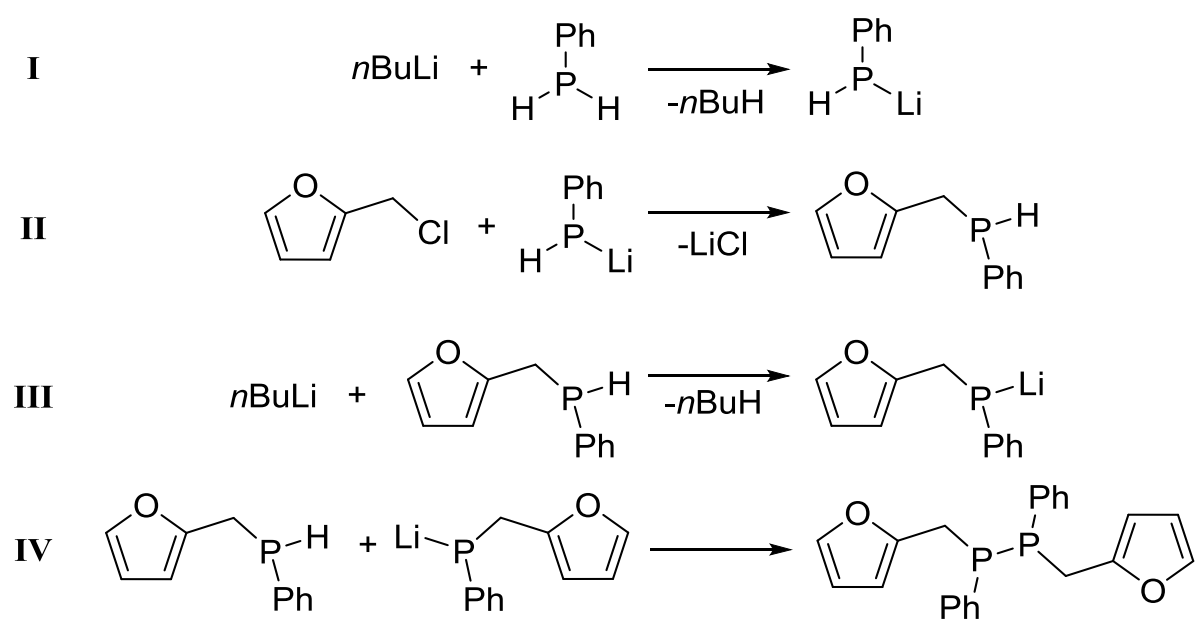

Scheme 3-15. Possible formation of the diphosphane.

\subsection{1 $\quad\left[\left\{(\text { FurPh })_{2} \mathbf{P}_{2}\right\} \mathrm{Au}_{2} \mathrm{Cl}_{2}(\mathrm{FurPhPH})\right](23)$}

Initial coordination reactions with the crude product and different metal salts, e.g. $\mathrm{NiCl}_{2},\left(\mathrm{Me}_{2} \mathrm{~S}\right) \mathrm{AuCl}$, and $\mathrm{PbCl}_{2}$, were undertaken to study if bisfurfurylphenylphosphane binds to the metal atom via the phosphorus atom, alike 13-18, or a coordination of the furyl group takes place as well.

The metal salts were dissolved in toluene and two equivalents of bisfurfurylphenylphosphane were added. The reaction mixtures turned yellow-orange in all cases and was stirred over night at room temperature. After storage at $-44{ }^{\circ} \mathrm{C}$ for several days, the solvent was partly removed and the reaction mixture was again stored at $-44^{\circ} \mathrm{C}$. Only the reaction with the gold salt yielded crystals after three weeks. The crystallization for the nickel and lead batch have been inconclusively until today. 
The $\mathrm{Au}(\mathrm{I})$-complex $\left[\left\{(\mathrm{FurPh})_{2} \mathrm{P}_{2}\right\} \mathrm{Au}_{2} \mathrm{Cl}_{2}(\mathrm{FurPhPH})\right](\mathbf{2 3})$ crystallizes in the triclinic space group $P \overline{1}$ with half the molecule in the asymmetric unit. The complete molecule is shown in Figure 3-13.

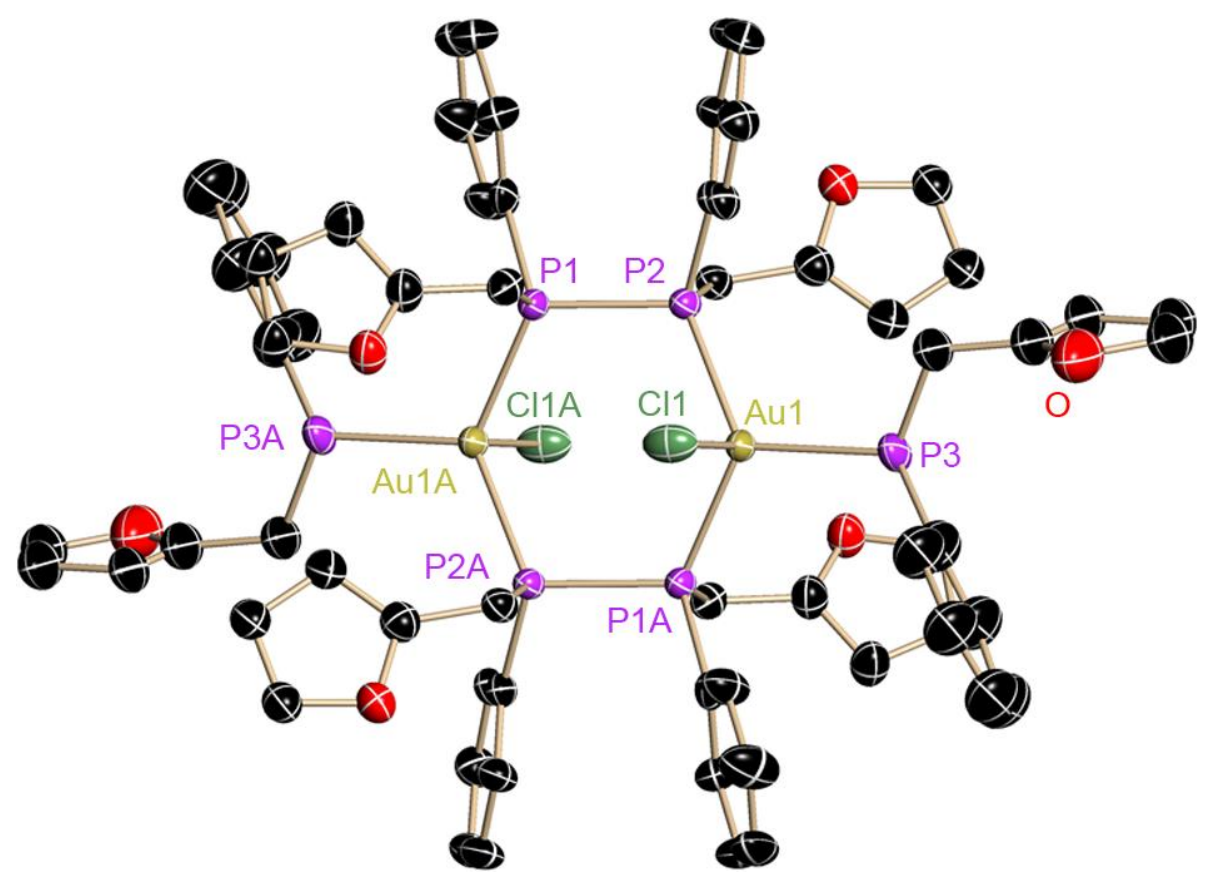

Figure 3-13. Molecular structure of $\left[\left\{(\mathrm{FurPh})_{2} \mathrm{P}_{2}\right\} \mathrm{Au}_{2} \mathrm{Cl}_{2}(\mathrm{FurPhPH})\right](\mathbf{2 3})$. Anisotropic displacement parameters are depicted at the 50\% probability level. Hydrogen atoms, solvent molecule toluene and disorder of the furfuryl moieties are omitted.

Unfortunately only the byproducts of the crude product of bisfurfurylphenylphosphane coordinate to the gold atoms. The gold atoms are coordinated by the phosphorus atoms of the diphosphane, forming a $\mathrm{P}_{4} \mathrm{Au}_{2}$-six-membered ring in a chair conformation. The trigonal pyramidal coordination sphere of the $\mathrm{Au}(\mathrm{I})$ atoms is completed by a chlorine atom and the phosphorus atom of a (Fur) $\mathrm{PhPH}$ molecule, a further byproduct of the unsuccessful formation of bisfurfurylphenylphosphane. The $\mathrm{P}-\mathrm{Au}-\mathrm{P}$ angles are in a range of $115-119^{\circ}$, the $\mathrm{P}-\mathrm{Au}-\mathrm{Cl}$ angles are in the range of $95-103^{\circ}$, respectively. Therefore the coordination geometry of the gold atom could be described as trigonal pyramidal instead of a distorted tetrahedral coordination. The $\mathrm{Au}-\mathrm{P}$ bond lengths (2.365(12) $\AA$ ) are in the range of Au-P distances in trigonal pyramidal coordinated gold complexes (average value in the CSD: $2.358 \AA$ ).

A CSD search revealed complexes which contain $\mathrm{Au}-\mathrm{P}_{2}-\mathrm{Au}$ motif ${ }^{[145]}$, and only of them contains a $\mathrm{P}_{4} \mathrm{Au}_{2}$-six-membered ring ${ }^{[146]}$, but with a $\left[\mathrm{Cp}_{2} \mathrm{Mo}_{2}(\mathrm{CO})_{4}\left(\mu, \eta^{2}-\mathrm{P}_{2}\right)\right.$ fragment (Figure 3-14) instead of a diphosphane as in $\mathbf{2 3}$. 


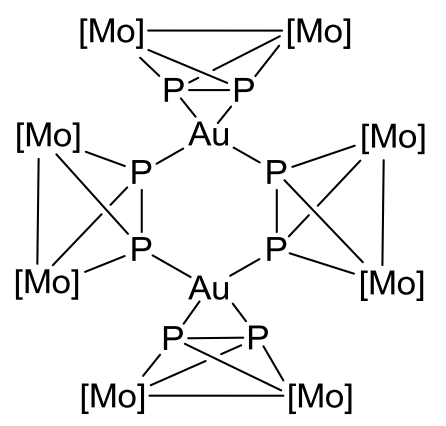

Figure 3-14. $\mathrm{P}_{4} \mathrm{Au}_{2}$-six-membered ring. ${ }^{[146]}$

Hence by coincidence a new coordination motif for diphosphane-gold complexes was found. This was formed instead of the desired potential Janus head ligand, where a coordination of the phosphorus atom and the oxygen atoms of the furyl moiety was expected. Obtaining the desired product requires improvement by stepwise lithiation of $\mathrm{PhPH}_{2}$ and addition of furfurylchloride to avoid formation of the byproduct. Unfortunately the structure of $\mathbf{2 3}$ only showed coordination by the unsolicited byproducts.

Moreover, this failed reaction reflects another sorely proof for the impossibility of the in situ dilithiation of a phosphane as previously stated by Wright et al. ${ }^{[144,147]}$

\subsubsection{Furfuryloxy- and 2-Thienylmethoxy substituted Phosphonous Diesters}

An alternative route to those described in the previous section for the synthesis of a furyl or thienyl substituted Janus head ligand should be investigated. Arduengo showed the reaction of dichlorophenylphosphane with phenol derivates to form phenylphosphonous diester. ${ }^{[148]}$ The $\mathrm{P}-\mathrm{O}$ coupling was proceeded by a base supported reaction (Scheme 3-16).<smiles>[R]C(=O)c1ccccc1OP(Oc1ccccc1)Oc1ccccc1C([R])=O</smiles>

Scheme 3-16. Synthesis of a phenylphosphonous diester by Arduengo. ${ }^{[148]}$ 
Furthermore Koole et al. showed the synthesis of phenylbis(tetrahydrofurfuryloxy)phosphane by the coupling of furfuryl alcohol with dichlorophenylphosphane (Scheme $3-17){ }^{[149]}$

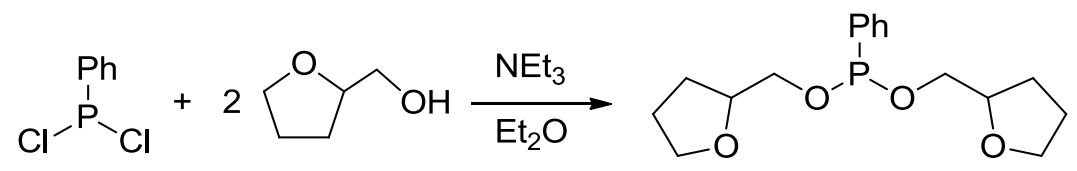

Scheme 3-17. Synthesis of phenylbis(tetrahydrofurfuryloxy)phosphane. ${ }^{[149]}$

This reaction scheme was used as inspiration and modified to form the phosphonous diester with furfuryl alcohol or 2-thienyl-methanol instead of tetrahydrofurfuryl alcohol (Scheme 3-17). The introduction of the $\mathrm{P}-\mathrm{O}$ bond should help to build a thienylmethylor furfuryl-substituted ligand, designed to act as a Janus head ligand which could coordinate hard and soft metals through its two donor sites and the enlarged bite angle in comparison with ligands presented earlier in this chapter.

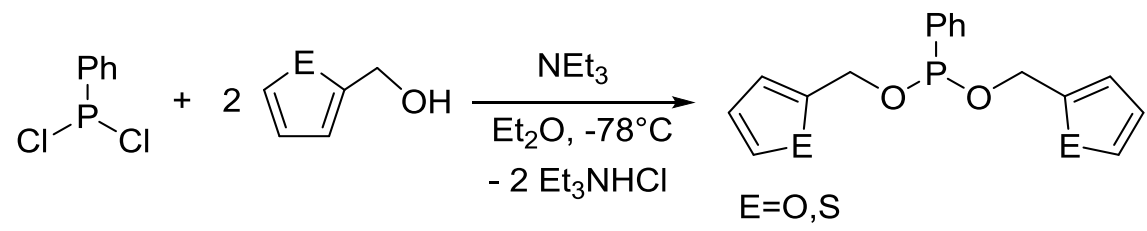

Scheme 3-18. Synthesis of furfuryloxy- and 2-thienylmethoxy subistuted phosphonus diester.

Furfuryl alcohol or 2-thienyl-methanol, respectively, and $\mathrm{NEt}_{3}$ were dissolved in diethylether and dichlorophenylphosphane was added dropwise at $-78^{\circ} \mathrm{C}$. The formed precipitate was isolated, the solvent removed and the crude product, an oil, was obtained. The oil was then filtered again to remove the newly precipitated ammonium chloride and the residue was dissolved in $n$-pentane which led to further precipitation of ammonium chloride. The ${ }^{31} \mathrm{P}$ NMR analysis showed several signals, indicating an incomplete reaction. Mass spectrometry revealed both products to be formed. $\mathrm{m} / \mathrm{z} 302$ and 334, respectively, for the furfuryloxy- and 2-thienylmethoxy phophonus diesters within the crude product mixture.

The procedure was changed to obtain a complete reaction. Therefore, dichlorophenylphosphane was dissolved in diethyl ether and a solution of furfuryl alcohol and $\mathrm{NEt}_{3}$ in diethyl ether was added dropwise at $0^{\circ} \mathrm{C}$. Subsequently the reaction mixture was heated to reflux for several hours. The above mentioned problems during the purification 
occurred again. A distillation of the crude product led to its decomposition. Again the ${ }^{1} \mathrm{H}$ and ${ }^{31} \mathrm{P}$ NMR spectra of the reaction products showed the formation of unidentified byproducts.

In conclusion, insertion of a methylene bridge in thienyl and furyl substituted phosphane exhibited more difficulties than expected. Early problems in the preparation of the starting materials from commercially available alcohols to halides were often the drawback in the synthesis. Furthermore the work up strategies reported in literature were not straightforward and pure compounds could not be isolated.

Nevertheless it seems that these phosphanes have the characteristics to be promising Janus head ligands and further investigation into finding a convient way to access these ligands should take place. The oxygen is likely to be the most promising ligand in comparison with sulfur containing derivates, due to its better donor capability. Insertion of the methylene group would open a further coordination site when metallated, similar to the anionic $\mathrm{PhPPic}_{2}{ }^{[47 \mathrm{~b}]}$ and $\mathrm{Ph}_{2} \mathrm{Pic}^{[42 \mathrm{c}]}$ ligands. 


\section{SUMMARY AND OUTLOOK}

Extensive structural investigations of 2-thienyllithium and its derivatives were realised in the course of this thesis. The resulting aggregates were characterised by single crystal $\mathrm{X}$-ray diffraction experiments as well as multinuclear NMR experiments, yielding information about the aggregation in the solid state and solution, respectively. It could be shown that in the solid state the tetramer $\left[\left(\mathrm{Et}_{2} \mathrm{O}\right) \mathrm{Li}\left(\mathrm{C}_{4} \mathrm{H}_{3} \mathrm{~S}\right)\right]_{4}(\mathbf{1})$ forms dimers when treated with THF, DME and TMEDA, and a monomer when subjected to PMDETA. For the given system ${ }^{13} \mathrm{C}$ NMR experiments indicate the aggregation state in solution by the downfield shift of the $\mathrm{C}_{\alpha}$ signal from the tetramer to the monomer. With more significant 2D NMR, i.e. HOESY and DOSY experiments it could be confirmed that the structures of 3-5 of the solid state are maintained upon dissolving in toluene. ${ }^{[56]}$

Future work must now prove if the solid-state structure of further lithium organics and mixed organometallic compounds is also retained in solvation by conducting similar combined single crystal X-ray diffraction experiments / NMR studies.

The first evidence on the reactivity has been given by the metallation of toluene- $d_{8}$ within the NMR experiments of $\mathbf{4}$ and $\mathbf{5}$ and proves the influence of a donor base to increase the reactivity of lithium organics.

5-Methyl-2-thienyllithium shows a very similar aggregation behaviour compared to 2-thienyllithium in the solid state and in solution, relying on the ${ }^{1} \mathrm{H}$ and ${ }^{13} \mathrm{C}$ shifts. The next step is the improvement of the crystallization conditions to obtain freshly grown crystals and conduct sophisticated 2D NMR experiments, i.e. HOESY and DOSY. Only then the aggregation in solution can be determined unequivocally and thoroughly compared to 2-thienyllithium aggregates.

Light was shed on a new aggregate of 2-thienyllithium with diglyme. The first solidstate structure of the first lithium-carbon pentuple ion is presented and another uncharted area on the map of the aggregations of lithiumorganics is explored (Scheme 4-1). 


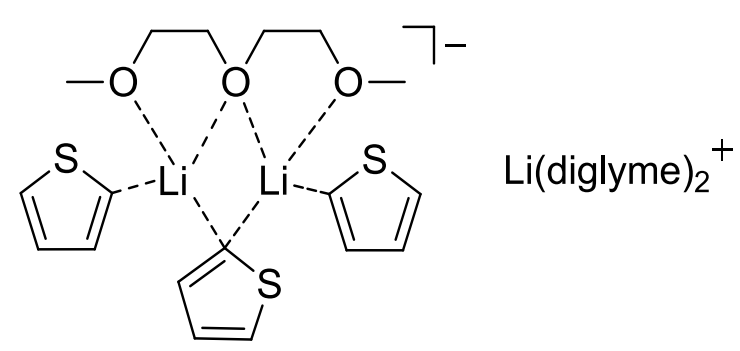

Scheme 4-1. The lithium lithiate 9.

Various single crystal $\mathrm{X}$-ray diffraction experiments with $\mathrm{Mo-}, \mathrm{Cu}$ - and synchrotron radiation at $100 \mathrm{~K}$ and $12 \mathrm{~K}$ were performed. The highly disordered molecules in the single crystal reduce the diffraction quality of the crystals. It is questionable if further crystallization attempts will lead to better quality.

2D NMR experiments must prove which aggregate is formed in solution, due to the fact, that mononuclear NMR spectra only indicate a change of aggregation upon dissolving in toluene- $d_{8}$. Furthermore, theoretical calculations might be helpful to confirm the aggregate formed in solution.

Two new aggregates of 2-furyllithium were isolated and their structures were determined by single crystal X-ray diffraction experiments during this thesis. While one of the aggregates performs an ether cleavage of DME and forms methoxy bridged $\mathrm{Li}_{12}$-cuboctahedrons the other one inserts a peroxide anion into its solid-state structures.

Within this work it was also possible to synthesize complexes of bis(2-thienyl)diethylaminophosphane with late transition metals. All complexes have in common that the metal ion is exclusively coordinated by the phosphorous atom. Neither the sulfur containing side chain nor the nitrogen atom coordinates to a metal atom.

Furthermore, the detailed reduction to the more promising Janus head ligand $\mathrm{Thi}_{2} \mathrm{PH}$ is presented. Improvements in the purification are necessary to obtain the pure ligand in high yields and test is donor properties.

First insights on the insertion of a methylene group in thienyl and furyl subsituted phosphanes are presented. These ligands are auspicious candidates to act as a neutral or, if deprotonated, anionic Janus head ligands. 


\section{EXPERIMENTAL SECTION}

\subsection{General Procedures}

All experimental manipulations were performed either in an inert gas atmosphere of purified dry nitrogen with standard Schlenk techniques ${ }^{[1 \mathrm{~b}, 150]}$ or in an argon glove box. The glassware was dried at $140{ }^{\circ} \mathrm{C}$, assembled hot and cooled down under vacuum. All solvents were dried over sodium, potassium or sodium-potassium alloy, distilled and degassed prior to use. The chemicals and solvents were commercially purchased, dried, freshly distilled before use and stored under inert atmosphere. The $n$-butyllithium, which was kindly contributed by the ROCKWOOD LITHIUM GmbH, was filtered through Celite before use and the concentration was determined by titration with diphenylacetic acid. $^{[151]}$

\subsubsection{Synthesis of Lithiated Heterocycles}

A solution of one equivalent of $n$ - $\mathrm{BuLi}\left(1.51 \mathrm{M}\right.$ in $n$-hexane) was added at $0{ }^{\circ} \mathrm{C}$ to a solution of the heterocycle ( 1 eq.) in $20 \mathrm{~mL}$ diethyl ether over 30 minutes. An excess of donor base (2.5 eq.) was added, followed by constant stirring for another 30 minutes. The solution was then cooled to $-78^{\circ} \mathrm{C}$. The crystals thus formed were filtered, washed twice with pre cooled $n$-hexane $\left(-78^{\circ} \mathrm{C}\right)$ and finally dried in vacuo.

This general method was applied for the synthesis of all presented compounds (1-11) with varying batch size for each reaction or product if not stated otherwise.

\subsection{Spectroscopic and Analytic Methods}

NMR spectra were recorded on a Bruker Avance DRX $500 \mathrm{MHz}, 300 \mathrm{MHz}$ or Avance III (300 MHz) spectrometer. Chemical shifts $\delta$ are given in ppm, whereas the coupling constant $J$ has the unit Hz. Tetramethylsilan served as external standard of ${ }^{1} \mathrm{H}$ NMR and ${ }^{13} \mathrm{C}\left\{{ }^{1} \mathrm{H}\right\}$ NMR spectra; the remaining solvent protons of the deuterated solvents represent the internal standard. ${ }^{[152]}$ The multiplets were abbreviated as described in the following: $\mathrm{br}=$ broad signal, $\mathrm{s}=$ singlet, $\mathrm{d}=$ doublet, $\mathrm{dd}=$ doublet of doublets, ddd $=$ doublet of doublets of doublets, $\mathrm{m}=$ multiplet. All spectra were 
recorded at ambient temperature if not mentioned otherwise. The obtained chemical shifts were assigned according to Scheme 5-1.
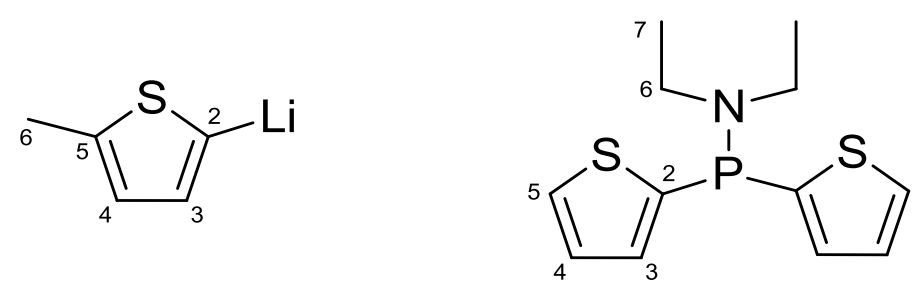

Scheme 5-1. Labeling scheme of NMR signals.

\subsection{Elemental Analyses}

Elemental analyses were carried out by the Analytische Labor des Instituts für Anorganische Chemie der Georg-August-Universität Göttingen with an Elementar Vario EL3. Some of the determined values of the air and moisture sensitive compounds deviate more than $1.0 \%$ from the calculated ones. This can be explained by the instability of the compounds when handled outside of a Schlenk flask or glove box, the loss of solvent molecules during the drying of the sample in vacuum or the inclusion of argon from canning the samples in an argon glove box.

\subsection{Mass Spectrometry}

EI-MS spectra were recorded on a MAT 95, $70 \mathrm{eV}$. The m/z-values of the ions and selected molecular fragments are described due to the isotopes with the highest natural abundance.

\subsection{Synthesis and Characterization}

\subsubsection{Synthesis of $\left[\left(\mathrm{Et}_{2} \mathrm{O}\right) \mathrm{Li}\left(\mathrm{C}_{4} \mathrm{H}_{3} \mathrm{~S}\right)\right]_{4}(1)$}

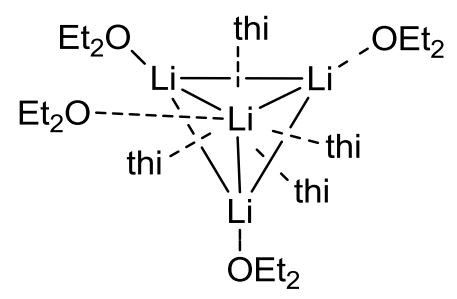


Colourless crystals of $\mathbf{1}$ were obtained after a few days.

Yield: $2.4 \mathrm{~g}, 52 \%$. $\mathrm{C}_{32} \mathrm{H}_{52} \mathrm{Li}_{4} \mathrm{O}_{4} \mathrm{~S}_{4}(\mathrm{M}=656.74 \mathrm{~g} / \mathrm{mol})$.

${ }^{1} \mathbf{H}$ NMR (300.13 MHz, tol- $\left.d_{8}\right): \quad \delta 7.80\left(\mathrm{~d},{ }^{3} J_{\mathrm{HH}}=4.3 \mathrm{~Hz}, 1 \mathrm{H}, \mathrm{H}_{5}\right), 7.63(\mathrm{~d}$, $\left.{ }^{3} J_{\mathrm{HH}}=2.7 \mathrm{~Hz}, 1 \mathrm{H}, \mathrm{H}_{3}\right), 7.33\left(\mathrm{dd},{ }^{3} J_{\mathrm{HH}}=4.3 \mathrm{~Hz}\right.$, $\left.{ }^{3} J_{\mathrm{HH}}=2.8 \mathrm{~Hz}, 1 \mathrm{H}, \mathrm{H}_{4}\right), 3.19\left(\mathrm{q},{ }^{3} J_{\mathrm{HH}}=7.0 \mathrm{~Hz} 6 \mathrm{H}\right.$, $\left.\mathrm{CH}_{3}\right), 0.96\left(\mathrm{t},{ }^{3} J_{\mathrm{HH}}=7.0 \mathrm{~Hz} 4 \mathrm{H}, \mathrm{CH}_{2}\right)$.

${ }^{13}$ C NMR (75.48 MHz, tol- $\left.d_{8}\right): \quad \delta 166.9\left(\mathrm{C}_{2}\right), 137.5\left(\mathrm{C}_{5}\right), 133.1\left(\mathrm{C}_{3}\right), 128.1\left(\mathrm{C}_{4}\right)$, $65.7\left(\mathrm{CH}_{3}\right), 15.1\left(\mathrm{CH}_{2}\right)$.

${ }^{7}$ Li NMR (116.64 MHz, tol- $\left.d_{8}\right): \quad \delta 2.7(\mathrm{~s})$.

Elemental Analysis: $\quad$ Calcd: C, 49.21; H, 2.96; S, 29.22. Found: C, $58.52 ; \mathrm{H}, 7.98 ; \mathrm{S}, 19.53$.

\subsubsection{Synthesis of $\left[(\mathrm{THF}) \mathrm{Li}\left(\mathrm{C}_{4} \mathrm{H}_{3} \mathrm{~S}\right)\right]_{4}(2)$}

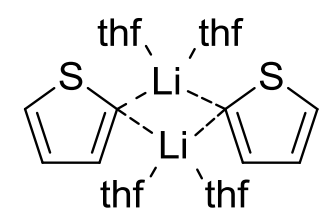

Colourless crystals of $\mathbf{2}$ were obtained after a few days.

Yield: $1.2 \mathrm{~g}, 18.5 \% . \mathrm{C}_{24} \mathrm{H}_{38} \mathrm{Li}_{2} \mathrm{O}_{4} \mathrm{~S}_{2}(468.54 \mathrm{~g} / \mathrm{mol})$.

${ }^{1} \mathbf{H}$ NMR (300.13 MHz, tol- $\left.d_{8}\right): \quad \delta 7.88\left(\mathrm{~d},{ }^{3} J_{\mathrm{HH}}=4.3 \mathrm{~Hz}, 1 \mathrm{H}, \mathrm{H}_{5}\right), 7.70(\mathrm{dd}$, $\left.{ }^{3} J_{\mathrm{HH}}=2.7 \mathrm{~Hz},{ }^{4} J_{\mathrm{HH}}=2.4 \mathrm{~Hz}, 1 \mathrm{H}, \mathrm{H}_{3}\right), 7.430(\mathrm{dd}$, $\left.{ }^{3} J_{\mathrm{HH}}=4.28 \mathrm{~Hz},{ }^{3} J_{\mathrm{HH}}=2.76 \mathrm{~Hz}, 1 \mathrm{H}, \mathrm{H}_{4}\right), 3.41(\mathrm{~m}$, $\left.8 \mathrm{H}, \mathrm{OCH}_{2}\right), 1.39\left(\mathrm{~m}, 8 \mathrm{H}, \mathrm{CH}_{2}\right)$.

${ }^{13}$ C NMR (75.48 MHz, tol- $\left.d_{8}\right): \quad \delta 170.9\left(\mathrm{C}_{2}\right), 137.2\left(\mathrm{C}_{5}\right), 131.6\left(\mathrm{C}_{3}\right), 127.7\left(\mathrm{C}_{4}\right)$, $65.7\left(\mathrm{OCH}_{2}\right), 25.7\left(\mathrm{CH}_{2}\right)$.

${ }^{7}$ Li NMR (116.64 MHz, tol- $\left.d_{8}\right): \quad \delta 1.9(\mathrm{~s})$. 


\subsubsection{Synthesis of $\left[(\mathrm{DME}) \mathrm{Li}\left(\mathrm{C}_{4} \mathrm{H}_{3} \mathrm{~S}\right)\right]_{4}(3)$}

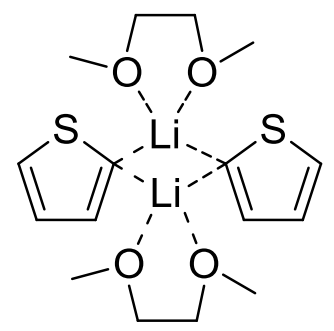

Colourless crystals of $\mathbf{3}$ were obtained after a few days.

Yield: $3.6 \mathrm{~g}, 79 \%$. $\mathrm{C}_{16} \mathrm{H}_{26} \mathrm{Li}_{2} \mathrm{O}_{4} \mathrm{~S}_{2}(360.39 \mathrm{~g} / \mathrm{mol})$.

${ }^{1} \mathbf{H}$ NMR (300.13 MHz, tol- $\left.d_{8}\right): \quad \delta 7.95\left(\mathrm{dd},{ }^{3} J_{\mathrm{HH}}=4.3 \mathrm{~Hz},{ }^{4} J_{\mathrm{HH}}=0.4 \mathrm{~Hz}, 1 \mathrm{H}, \mathrm{H}_{5}\right)$, $7.69\left(\mathrm{dd},{ }^{3} J_{\mathrm{HH}}=2.8 \mathrm{~Hz},{ }^{4} J_{\mathrm{HH}}=0.4 \mathrm{~Hz}, 1 \mathrm{H}, \mathrm{H}_{3}\right)$, $7.57\left(\mathrm{dd},{ }^{3} J_{\mathrm{HH}}=4.4 \mathrm{~Hz},{ }^{3} J_{\mathrm{HH}}=2.8 \mathrm{~Hz}, 1 \mathrm{H}, \mathrm{H}_{4}\right)$, $3.02\left(\mathrm{~s}, 6 \mathrm{H}, \mathrm{CH}_{3}\right), 2.72\left(\mathrm{~s}, 4 \mathrm{H}, \mathrm{CH}_{2}\right)$.

${ }^{13}$ C NMR (75.48 MHz, tol- $\left.d_{8}\right): \quad \delta 172.1\left(\mathrm{C}_{2}\right), 136.5\left(\mathrm{C}_{5}\right), 130.7\left(\mathrm{C}_{3}\right), 127.5\left(\mathrm{C}_{4}\right)$, $70.1\left(\mathrm{CH}_{3}\right), 58.8\left(\mathrm{CH}_{2}\right)$.

${ }^{7}$ Li NMR (116.64 MHz, tol- $\left.d_{8}\right): \quad \delta 1.7(\mathrm{~s})$.

Elemental Analysis: $\quad$ C, 52.34; H, 7.49; S, 17.08. Found: C, 53.32; H, 7.27; S, 17.79 .

\subsubsection{Synthesis of $\left[(\mathrm{TMEDA}) \mathrm{Li}\left(\mathrm{C}_{4} \mathrm{H}_{3} \mathrm{~S}\right)\right]_{2}(4)$}

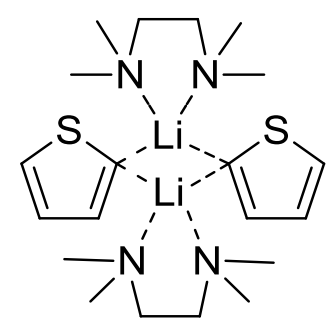

Colourless crystals of $\mathbf{4}$ were obtained after a few days.

Yield: $2.8 \mathrm{~g}, 49 \% . \mathrm{C}_{20} \mathrm{H}_{38} \mathrm{Li}_{2} \mathrm{~N}_{4} \mathrm{~S}_{2}(412.55 \mathrm{~g} / \mathrm{mol})$.

${ }^{1} \mathbf{H}$ NMR (300.13 MHz, tol- $\left.d_{8}\right): \quad \delta 7.92\left(\mathrm{~d},{ }^{3} J_{\mathrm{HH}}=5.0 \mathrm{~Hz}, 1 \mathrm{H}, \mathrm{H}_{5}\right), 7.66\left(\mathrm{~s}_{\mathrm{br}}, 1 \mathrm{H}\right.$, $\left.\mathrm{H}_{3}\right), 7.50\left(\mathrm{~d},{ }^{3} J_{\mathrm{HH}}=4.8 \mathrm{~Hz}, 1 \mathrm{H}, \mathrm{H}_{4}\right), 2.28(\mathrm{~s}, 12 \mathrm{H}$, $\left.\mathrm{CH}_{3}\right), 2.09$ (s, $\left.4 \mathrm{H}, \mathrm{CH}_{2}\right)$. 
${ }^{13}$ C NMR (75.48 MHz, tol- $\left.d_{8}\right): \quad \delta 174.4\left(\mathrm{C}_{2}\right), 137.2\left(\mathrm{C}_{5}\right), 130.8\left(\mathrm{C}_{3}\right), 127.4\left(\mathrm{C}_{4}\right)$, $58.4\left(\mathrm{CH}_{2}\right), 46.0\left(\mathrm{CH}_{3}\right)$.

${ }^{7}$ Li NMR (116.64 MHz, tol- $\left.d_{8}\right): \quad \delta 2.0(\mathrm{~s})$.

\subsubsection{Synthesis of [(PMDETA $\left.) \operatorname{Li}\left(\mathrm{C}_{4} \mathrm{H}_{3} \mathrm{~S}\right)\right](5)$}

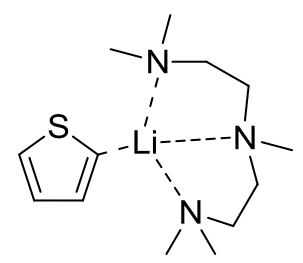

Colourless crystals of $\mathbf{5}$ were obtained after a few days.

Yield: $3.4 \mathrm{~g}, 47 \% . \mathrm{C}_{13} \mathrm{H}_{26} \mathrm{LiN}_{3} \mathrm{~S}(263.3 \mathrm{~g} / \mathrm{mol})$.

${ }^{1}$ H NMR (300.13 MHz, tol- $\left.d_{8}\right): \quad \delta 7.95\left(\mathrm{dd},{ }^{3} J_{\mathrm{HH}}=4.2 \mathrm{~Hz},{ }^{4} J_{\mathrm{HH}}=0.4 \mathrm{~Hz}, 1 \mathrm{H}, \mathrm{H}_{5}\right)$, $7.64\left(\mathrm{dd},{ }^{3} J_{\mathrm{HH}}=4.2 \mathrm{~Hz},{ }^{3} J_{\mathrm{HH}}=2.7 \mathrm{~Hz}, 1 \mathrm{H}, \mathrm{H}_{4}\right)$, $7.49\left(\mathrm{dd},{ }^{3} J_{\mathrm{HH}}=2.7 \mathrm{~Hz},{ }^{4} J_{\mathrm{HH}}=0.4 \mathrm{~Hz}, 1 \mathrm{H}, \mathrm{H}_{3}\right)$, $2.11\left(\mathrm{~s}, 3 \mathrm{H}, \mathrm{NCH}_{3}\right), 2.01\left(\mathrm{~s}, 12 \mathrm{H}, \mathrm{N}\left(\mathrm{CH}_{3}\right)_{2}\right), 1.86$ (br, $8 \mathrm{H}, \mathrm{CH}_{2}$ ).

${ }^{13} \mathrm{C}$ NMR (75.48 MHz, tol- $\left.d_{8}\right): \quad \delta 180.1\left(\mathrm{C}_{2}\right), 137.5\left(\mathrm{C}_{5}\right), 133.3\left(\mathrm{C}_{3}\right) 126.8\left(\mathrm{C}_{4}\right)$, $57.3\left(\mathrm{Me}_{2} \mathrm{NCH}_{2}\right), 53.9\left(\mathrm{CH}_{2} \mathrm{NMe}\right), 45.9\left(\mathrm{~N}\left(\mathrm{CH}_{3}\right)_{2}\right)$, $44.6\left(\mathrm{NCH}_{3}\right)$.

${ }^{7}$ Li NMR (116.64 MHz, tol- $\left.d_{8}\right): \quad \delta 2.1(\mathrm{~s})$.

\subsubsection{Synthesis of $\left[(\mathrm{THF})_{2} \mathrm{Li}\left\{\left(\mathrm{C}_{4} \mathrm{H}_{2} \mathrm{~S}\right)-5-\mathrm{Me}\right\}\right]_{2}(6)$}

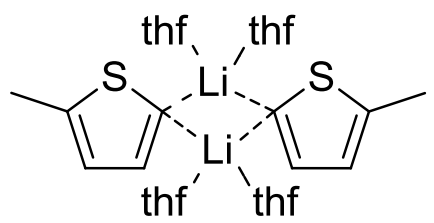

Only a few crystals of $\mathbf{6}$ were isolated and the structure could be determined by single crystal X-ray analysis.

Cyrstals decomposed when transferred to NMR tubes. 


\subsubsection{Synthesis of $\left[(\mathrm{DME}) \mathrm{Li}\left\{\left(\mathrm{C}_{4} \mathrm{H}_{2} \mathrm{~S}\right)-5-\mathrm{Me}\right\}\right]_{2}(7)$}

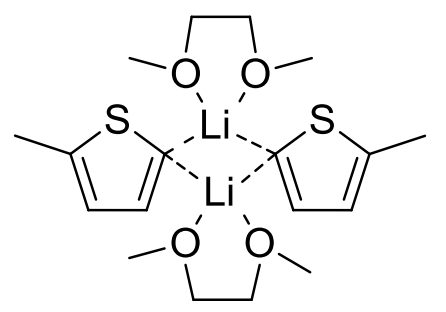

Colourless crystals of $\mathbf{7}$ were obtained after a five days.

Yield: $0.15 \mathrm{~g}, 67 \% . \mathrm{C}_{18} \mathrm{H}_{30} \mathrm{Li}_{2} \mathrm{O}_{4} \mathrm{~S}_{2}(669.42 \mathrm{~g} / \mathrm{mol})$.

${ }^{1} \mathbf{H}$ NMR $\left(500.13 \mathrm{MHz}\right.$, tol- $\left.d_{8}\right): \quad \delta 7.46\left(\mathrm{dd},{ }^{3} \mathrm{~J}_{\mathrm{HH}}=2.6 \mathrm{~Hz}, 1 \mathrm{H}, \mathrm{H}_{2}\right), 7.18(\mathrm{~m}, 1 \mathrm{H}$, $\left.\mathrm{H}_{3}\right), 3.09$ (s, $\left.6 \mathrm{H}, \mathrm{CH}_{3}\right), 2.85\left(\mathrm{~s}, 4 \mathrm{H}, \mathrm{CH}_{2}\right), 2.16(\mathrm{~d}$, $\left.{ }^{3} J_{\mathrm{HH}}=0.9 \mathrm{~Hz}, 3 \mathrm{H}, \mathrm{H}_{5}\right)$.

${ }^{13}$ C NMR (125MHz, tol- $\left.d_{8}\right): \quad \delta 172.2\left(\mathrm{C}_{1}\right), 144.2(\mathrm{C} 2), 136.7(\mathrm{C} 3), 127.2(\mathrm{C} 4)$, 70.4 (CH2), 58.8 (CH3), 15.4 (C5).

Elemental Analysis: $\quad$ C, 55.66; H, 7.78; S, 16.51. Found: C, 54.79; H, $8.02 ; \mathrm{S}, 15.74$.

\subsubsection{Synthesis of $\left[(T M E D A) L i\left\{\left(\mathrm{C}_{4} \mathrm{H}_{2} \mathrm{~S}\right)-4-\mathrm{Me}\right\}\right]_{2}(8)$}

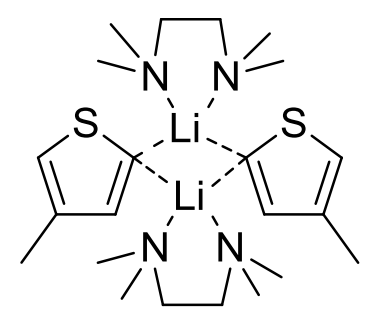

Colourless crystals of $\mathbf{8}$ were obtained after several days.

Yield: $1.12 \mathrm{~g}, 27 \% . \mathrm{C}_{18} \mathrm{H}_{30} \mathrm{Li}_{2} \mathrm{O}_{4} \mathrm{~S}_{2}(338.44 \mathrm{~g} / \mathrm{mol})$

${ }^{1} \mathbf{H}$ NMR (500MHz, tol- $\left.d_{8}\right): \quad \delta 7.98\left(\mathrm{~d},{ }^{3} J_{\mathrm{HH}}=4.2 \mathrm{~Hz}, 1 \mathrm{H}, \mathrm{H}_{4}\right), 7.43(\mathrm{~d}$, $\left.{ }^{3} J_{\mathrm{HH}}=4.1 \mathrm{~Hz}, 1 \mathrm{H}, \mathrm{H}_{2}\right), 2.88\left(\mathrm{~s}, 3 \mathrm{H}, \mathrm{CH}_{3}\right), 2.56(\mathrm{~s}$, $\left.4 \mathrm{H}, \mathrm{CH}_{2}\right), 1.99$ (s, $\left.12 \mathrm{H}, \mathrm{CH}_{3}\right)$.

${ }^{13}$ C NMR (125MHz, tol- $\left.d_{8}\right): \quad \delta 176.7\left(\mathrm{C}_{1}\right), 146.2$ (C3), 131.7 (C2), 129.9 (C4), $127.3\left(\mathrm{CH}_{2}\right), 46.4(\mathrm{CH} 3), 21.5(\mathrm{C} 5)$. 
Elemental Analysis: $\quad$ C, 58.23; H, 9.28; N, 13.58; S, 15.54. Found: C, 59.82; H, 10.40; N, 12.67; S, 14.35.

\subsubsection{Synthesis of $\left[\mathrm{Li}(\text { Diglyme })_{2}\right]\left[(\right.$ Diglyme $\left.) \operatorname{Li}_{2}\left(\mathrm{C}_{4} \mathrm{H}_{3} \mathrm{~S}\right)_{3}\right](9)$}

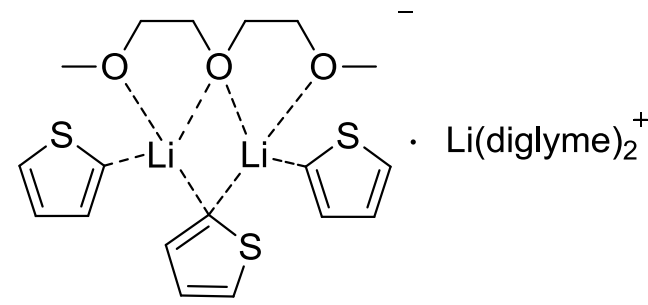

To a solution of thiophene $(1.0 \mathrm{~mL}, 12.7 \mathrm{mmol})$ in $10 \mathrm{~mL}$ diethyl ether a solution of one equivalent of $n$-BuLi (2.5 $\mathrm{M}$ in $n$-hexane) was added at $0{ }^{\circ} \mathrm{C}$ over 10 minutes and stirred for another $15 \mathrm{~min}$. An excess of diglyme (2.5 eq.) was added followed by constant stirring for another 20 minutes. The solution was then stored at $-19^{\circ} \mathrm{C}$. The crystals thus formed were used for the X-ray analysis or transferred to septum tapped NMR-tubes or the tubes were molten off for the NMR experiments.

Note: The reaction can be performed in various concentrations and scales to obtain $\mathbf{9}$, but the crystallisation at $-19^{\circ} \mathrm{C}$ is crucial. At lower $\left(-40 /-80{ }^{\circ} \mathrm{C}\right)$ or higher $\left(-12-0^{\circ} \mathrm{C}\right)$ temperatures crystals of lower quality or powdery solids were formed

Crystals of 9 were only stable in their mother liquor and could not be isolated dryly.

${ }^{1} \mathbf{H}$ NMR $\left(300.13 \mathrm{MHz}\right.$, tol- $\left.d_{8}\right): \quad \delta 7.97\left(\mathrm{~d},{ }^{3} J_{\mathrm{HH}}=4.1 \mathrm{~Hz}, 1 \mathrm{H}, \mathrm{H}_{4}\right), 7.71\left(\mathrm{~d},{ }^{3} J_{\mathrm{HH}}=\right.$ $\left.2.7 \mathrm{~Hz}, 1 \mathrm{H}, \mathrm{H}_{2}\right), 7.58\left(\mathrm{dd},{ }^{3} J_{\mathrm{HH}}=4.2 \mathrm{~Hz},{ }^{3} J_{\mathrm{HH}}=\right.$ $\left.2.8 \mathrm{~Hz}, 1 \mathrm{H}, \mathrm{H}_{3}\right), 3.20\left(\mathrm{~m}, 8 \mathrm{H}, \mathrm{CH}_{2}\right), 3.10(\mathrm{~s}, 6 \mathrm{H}$, $\left.\mathrm{CH}_{3}\right)$.

${ }^{13}$ C NMR (75.48 MHz, tol- $\left.d_{8}\right): \quad \delta$

$172.6\left(\mathrm{C}_{1}\right), 136.9\left(\mathrm{C}_{2}\right), 130.7\left(\mathrm{C}_{4}\right), 127.6\left(\mathrm{C}_{3}\right), 71.5$ $\left(\mathrm{CH}_{2}\right), 69.9\left(\mathrm{CH}_{2}\right), 58.7\left(\mathrm{CH}_{3}\right) \mathrm{ppm}$.

${ }^{7}$ Li NMR (116.64 MHz, tol- $\left.d_{8}\right): \quad \delta 1.85$. 


\subsubsection{Synthesis of $\mathrm{Thi}_{2} \mathrm{PNEt}_{2}(\mathbf{1 2})$}<smiles>CCN(CC)P(c1cccs1)c1cccs1</smiles>

The synthesis of $\mathbf{1 2}$ was performed according to the literature. ${ }^{[101]}$ To a suspension of Mg turning (16.7 g, $0.689 \mathrm{mmol}, 2.50$ eq.) was added a solution of 2-bromothiophene $(99.7 \mathrm{~g}, 0.611 \mathrm{mmol}, 57.3 \mathrm{~mL}, 2.22 \mathrm{eq}$.) in thf $(40 \mathrm{~mL})$ drop wise until the reaction started. The residual solution was added under retaining of the reflux over an hour, cooled down and stirred overnight. The unreacted magnesium turnings were removed (P2 frit) and the precipitate rinsed with $n$-pentane $(4 \times 50 \mathrm{~mL})$. The filtrate was cooled to $0^{\circ} \mathrm{C}$ and $\mathrm{NEt}_{2} \mathrm{PCl}_{2}(47.8 \mathrm{~g}, 275 \mathrm{mmol}, 40.0 \mathrm{~mL}, 1.00$ eq. $)$ was added drop by drop and allowed to warm to r.t. overnight. To remove the precipitate $n$-pentane $(200 \mathrm{~mL})$ were added and the solids removed (P2 frit) and rinsed with $n$-pentane (5 x $50 \mathrm{~mL})$. All volatile solvents were removed under reduced pressure and the residual filtered over Celite (P4 frit) and rinsed with $n$-pentane ( $3 \times 15 \mathrm{~mL}) .12$ was obtained after removal of the solvents as a yellow oil.

Yield: $41.3 \mathrm{~g}, 56 \% . \mathrm{M}=269.37 \mathrm{~g} / \mathrm{mol}$

${ }^{1} \mathbf{H}$ NMR $\left(300.13 \mathrm{MHz}, \mathrm{C}_{6} \mathrm{D}_{6}\right): \quad \delta 7.17\left(\mathrm{~m}, 4 \mathrm{H}, \mathrm{H}_{3}, \mathrm{H}_{5}\right), 6.82\left(\mathrm{ddd},{ }^{3} J_{\mathrm{HH}}=4.8 \mathrm{~Hz}\right.$, $\left.{ }^{3} J_{\mathrm{HH}}=3.5 \mathrm{~Hz},{ }^{4} J_{\mathrm{PH}}=1.2 \mathrm{~Hz}, 2 \mathrm{H}, \mathrm{H}_{4}\right), 3.08(\mathrm{dq}$, $\left.{ }^{3} J_{\mathrm{PH}}=10.7 \mathrm{~Hz},{ }^{3} J_{\mathrm{HH}}=7.1 \mathrm{~Hz}, 4 \mathrm{H}, \mathrm{CH}_{2}\right), 0.90(\mathrm{t}$, $\left.{ }^{3} J_{\mathrm{HH}}=7.1 \mathrm{~Hz}, 6 \mathrm{H}, \mathrm{CH}_{3}\right)$.

${ }^{13}$ C NMR (75.48 MHz, $\left.\mathrm{C}_{6} \mathrm{D}_{6}\right): \quad \delta 143.14 \quad\left(\mathrm{~d},{ }^{1} J_{\mathrm{PC}}=30.3 \mathrm{~Hz}, \mathrm{C}_{2}\right), 133.47 \quad(\mathrm{~d}$, $\left.{ }^{2} J_{\mathrm{PC}}=23.8 \mathrm{~Hz}, \mathrm{C}_{3}\right), 130.45\left(\mathrm{~d},{ }^{3} J_{\mathrm{PC}}=2.2 \mathrm{~Hz}, \mathrm{C}_{5}\right)$, $127.81 \quad\left(\mathrm{~d}, \quad{ }^{3} J_{\mathrm{PC}}=5.9 \mathrm{~Hz}, \quad \mathrm{C}_{4}\right), \quad 44.18 \quad(\mathrm{~d}$, $\left.{ }^{2} J_{\mathrm{PC}}=15.8 \mathrm{~Hz}, \quad C \mathrm{H}_{2}\right), \quad 14.44 \quad\left(\mathrm{~d},{ }^{3} J_{\mathrm{PC}}=3.8 \mathrm{~Hz}\right.$, $\left.\mathrm{CH}_{3}\right)$.

${ }^{31} \mathbf{P}$ NMR $\left(121.49 \mathrm{MHz}, \mathrm{C}_{6} \mathrm{D}_{6}\right): \quad \delta 38.69\left(\mathrm{pt},{ }^{3} J_{\mathrm{PH}}=10.7 \mathrm{~Hz},{ }^{3} J_{\mathrm{PH}}=4.6 \mathrm{~Hz}\right)$. 


\subsubsection{Synthesis of $\left[\left(\mathrm{SC}_{4} \mathrm{H}_{3}\right)_{2}\left(\mathrm{NEt}_{2}\right) \mathrm{PNiCl}_{2}\right] \cdot\left(\mathrm{C}_{7} \mathrm{H}_{8}\right)(13)$}

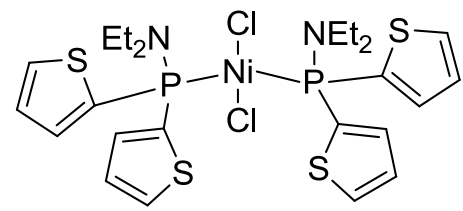

To $\mathrm{NiCl}_{2}$ (diglyme) $(0.60 \mathrm{~g}, 1.4 \mathrm{mmol})$ in toluene $(15 \mathrm{~mL})$ was added $12(0.74 \mathrm{~g}$, $1.4 \mathrm{mmol}$ ). Light-green crystals could be isolated after several days at $-20{ }^{\circ} \mathrm{C}$.

${ }^{1} \mathbf{H}$ NMR $\left(300.13 \mathrm{MHz}, \mathrm{C}_{6} \mathrm{D}_{6}\right): \quad \delta 7.79\left(\left(\mathrm{ddd},{ }^{3} J_{\mathrm{HH}}=7.8 \mathrm{~Hz},{ }^{3} J_{\mathrm{HH}}=3.5,{ }^{4} J_{\mathrm{HH}}=1.1\right.\right.$, $\left.2 \mathrm{H}, \mathrm{H}_{5}\right), 7.05\left(\mathrm{dd},{ }^{3} J_{\mathrm{HH}}=4.8,{ }^{3} J_{\mathrm{HH}}=2.3 \mathrm{~Hz}, 2 \mathrm{H}\right.$, $\left.\mathrm{H}_{4}\right) .6 .73\left(\mathrm{ddd},{ }^{3} J_{\mathrm{HH}}=4.9 \mathrm{~Hz},{ }^{3} J_{\mathrm{HH}}=3.6,{ }^{4} J_{\mathrm{HH}}\right.$ $\left.=1.5, \quad 1 \mathrm{H}, \quad \mathrm{H}_{3}\right), \quad 3.31 \quad\left(\mathrm{dq}, \quad{ }^{3} J_{\mathrm{PH}}=14.0 \mathrm{~Hz}\right.$, $\left.{ }^{3} J_{\mathrm{HH}}=7.0 \mathrm{~Hz}, \quad 4 \mathrm{H}, \quad \mathrm{NCH}_{2} \mathrm{CH}_{3}\right), \quad 0.95 \quad(\mathrm{t}$, $\left.{ }^{3} J_{\mathrm{HH}}=7.0 \mathrm{~Hz}, 6 \mathrm{H}, \mathrm{NCH}_{2} \mathrm{CH}_{3}\right)$.

${ }^{31} \mathbf{P}$ NMR (121.49 MHz, $\left.\mathrm{C}_{6} \mathrm{D}_{6}\right): \quad \delta 38.8$. free ligand

Elemental Analysis: $\quad \mathrm{C}, 42.60 ; \mathrm{H}, 4.83 ; \mathrm{N}, 4.18, \mathrm{~S}, 17.38$. Found: C, $43.13 ; \mathrm{H}, 4.83 ; \mathrm{N}, 4.19 ; \mathrm{S}, 17.19$.

EI-MS: $\mathrm{m} / \mathrm{z}(\%)$ :

$442\left[\mathrm{M}_{\mathrm{Br} / \mathrm{Cl}}-\mathrm{L}\right]^{+}, 362\left[\mathrm{M}_{\mathrm{Cl}}-\mathrm{L}-\mathrm{Cl}\right]^{+}, 329\left[\mathrm{M}_{\mathrm{Cl}}-\mathrm{L}-\right.$ $\left.\mathrm{Cl}_{2}\right]^{+}, 269.0\left[\mathrm{Thi}_{2} \mathrm{PNEt}_{2}\right]^{+}, 197.0\left[\mathrm{Thi}_{2} \mathrm{P}\right]^{+}, 115.0$ [PThi $^{+}$.

\subsubsection{Synthesis of $\left[\left(\mathrm{SC}_{4} \mathrm{H}_{3}\right)_{2}\left(\mathrm{NEt}_{2}\right) \mathrm{PCuCl}(\mathrm{MeCN})\right]_{2}(14)$}

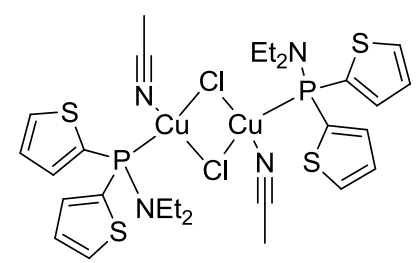

To $\mathrm{CuCl}(0.10 \mathrm{~g}, 10.0 \mathrm{mmol})$ in acetonitril $(15 \mathrm{~mL})$ was added $12(2.7 \mathrm{~g}, 10.0 \mathrm{mmol})$. colorless crystals could be isolated after seven days at $-20{ }^{\circ} \mathrm{C}$.

${ }^{1}$ H NMR (300.13 MHz, $\left.\mathrm{C}_{6} \mathrm{D}_{6}\right): \quad \delta 7.80\left(\mathrm{ddd},{ }^{3} J_{\mathrm{HH}}=7.8 \mathrm{~Hz},{ }^{3} J_{\mathrm{HH}}=7.4,{ }^{4} J_{\mathrm{HH}}=1.1\right.$, $\left.1 \mathrm{H}, \mathrm{H}_{5}\right) 7.06\left(\mathrm{dt},{ }^{3} J_{\mathrm{HH}}=4.8,{ }^{4} J_{\mathrm{PH}}=1.2 \mathrm{~Hz}, 1 \mathrm{H}\right.$, $\left.\mathrm{H}_{4}\right), \quad 6.74\left(\mathrm{ddd}, \quad{ }^{3} J_{\mathrm{HH}}=4.9 \mathrm{~Hz}, \quad{ }^{3} J_{\mathrm{HH}}=3.6\right.$, 


$$
\begin{gathered}
\left.{ }^{4} J_{\mathrm{HH}}=1.5,1 \mathrm{H}, \mathrm{H}_{3}\right), 3.33\left(\mathrm{q},{ }^{3} J_{\mathrm{PH}}=14.0 \mathrm{~Hz}, 2 \mathrm{H},\right. \\
\left.\mathrm{NCH}_{2} \mathrm{CH}_{3}\right), 0.95\left(\mathrm{t},{ }^{3} J_{\mathrm{HH}}=7.0 \mathrm{~Hz}, 3 \mathrm{H}, \mathrm{NCCH}_{3}\right) .
\end{gathered}
$$

${ }^{31} \mathbf{P}$ NMR (121.49 MHz, $\left.\mathrm{C}_{6} \mathrm{D}_{6}\right): \quad \delta 30.9$.

Elemental Analysis: $\quad$ C, 40.85; H, 4.65; N, 6.81, S, 15.58. Found: C, $38.62 ; \mathrm{H}, 4.39 ; \mathrm{N}, 3.98 ; \mathrm{S}, 16.48$.

\subsubsection{Synthesis of $\left[\left\{\left(\mathrm{SC}_{4} \mathrm{H}_{3}\right)_{2}\left(\mathrm{NEt}_{2}\right) \mathrm{P}\right\}_{2} \mathrm{PdCl}_{2}\right](15)$}

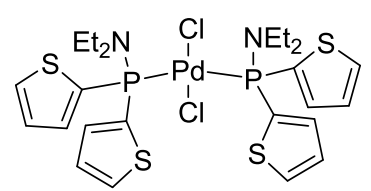

To $\mathrm{PdCl}_{2}(\mathrm{NCPh})_{2}(0.79 \mathrm{~g}, 2.93 \mathrm{mmol})$ in toluene $(25 \mathrm{~mL})$ was added $12(2.24 \mathrm{~g}$, $5.8 \mathrm{mmol})$. Orange crystals could be isolated after seven days at $-20{ }^{\circ} \mathrm{C}$.

Unfortunately, only a few crystals could be isolated, therefor no further analysis was conducted.

\subsubsection{Synthesis of $\left[\left(\mathrm{SC}_{4} \mathrm{H}_{3}\right)_{2}\left(\mathrm{NEt}_{2}\right) \mathrm{PCl}\right]_{2} \cdot\left(\mathrm{C}_{7} \mathrm{H}_{8}\right)(16)$}

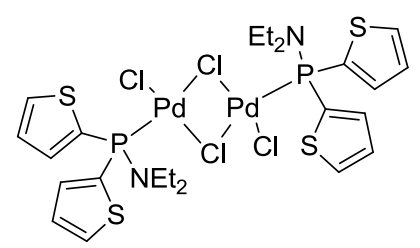

To $\mathrm{PdCl}_{2}(\mathrm{NCPh})_{2}(0.53 \mathrm{~g}, 0.93 \mathrm{mmol})$ in toluene $(15 \mathrm{~mL})$ was added $12(0.37 \mathrm{~g}$, $0.93 \mathrm{mmol})$. Orange-red crystals could be isolated after seven days at $-20{ }^{\circ} \mathrm{C}$.

${ }^{1} \mathbf{H}$ NMR $\left(300.13 \mathrm{MHz}, \mathrm{C}_{6} \mathrm{D}_{6}\right): \quad \delta 7.93\left(\mathrm{ddd},{ }^{3} J_{\mathrm{HH}}=6.8 \mathrm{~Hz},{ }^{3} J_{\mathrm{HH}}=3.3,{ }^{4} J_{\mathrm{HH}}=1.1\right.$, $\left.1 \mathrm{H}, \mathrm{H}_{5}\right), 7.06\left(\mathrm{dd},{ }^{3} J_{\mathrm{HH}}=4.9,{ }^{4} J_{\mathrm{PH}}=1.2 \mathrm{~Hz}, 1 \mathrm{H}\right.$, $\left.\mathrm{H}_{4}\right), \quad 6.75 \quad\left(\mathrm{ddd}, \quad{ }^{3} J_{\mathrm{HH}}=4.6 \mathrm{~Hz}, \quad{ }^{3} J_{\mathrm{PH}}=1.7\right.$, $\left.{ }^{4} J_{\mathrm{HH}}=0.9, \quad 1 \mathrm{H}, \mathrm{H}_{3}\right), \quad 3.31\left(\mathrm{dq},{ }^{3} J_{\mathrm{PH}}=14.0 \mathrm{~Hz}\right.$, $\left.{ }^{3} J_{\mathrm{HH}}=7.0 \mathrm{~Hz}, \quad 2 \mathrm{H}, \quad \mathrm{NCH}_{2} \mathrm{CH}_{3}\right), \quad 1.03 \quad(\mathrm{t}$, ${ }^{3} J_{\mathrm{HH}}=7.1 \mathrm{~Hz}, 3 \mathrm{H}, \mathrm{NCH}_{2} \mathrm{CH}_{3}$ ), 
${ }^{31} \mathbf{P}$ NMR (121.49 MHz, $\left.\mathrm{C}_{6} \mathrm{D}_{6}\right): \quad \delta$ 38.8. free ligand

\subsubsection{Synthesis of $\left[\left(\mathrm{SC}_{4} \mathrm{H}_{3}\right)_{2}\left(\mathrm{NEt}_{2}\right) \operatorname{PIrCl}(\mathrm{COD})\right] \cdot\left(\mathrm{C}_{7} \mathrm{H}_{8}\right)(17)$}<smiles>CCNP(Cl)(c1cccs1)(c1cccs1)[13C](=O)[O-]</smiles>

To $[\operatorname{IrCl}(\mathrm{COD})]_{2}(0.01 \mathrm{~g}, 0.015 \mathrm{mmol})$ in toluene $(5 \mathrm{~mL})$ was added $12(0.008 \mathrm{~g}$, $0.03 \mathrm{mmol})$. Orange crystals could be isolated after seven days at $-20{ }^{\circ} \mathrm{C}$.

${ }^{31}$ P NMR (121.49 MHz, $\left.\mathrm{C}_{6} \mathrm{D}_{6}\right): \quad \delta$ 38.8. free ligand,

EI-MS: $\mathrm{m} / \mathrm{z}(\%)$ :

$$
\begin{aligned}
& 649.0\left[\mathrm{M}_{\mathrm{Br}}\right]^{+}, 605.0\left[\mathrm{M}_{\mathrm{Cl}}\right]^{+}, 577.0\left[\mathrm{M}_{\mathrm{Br}}-\mathrm{NEt}_{2}\right]^{+}, \\
& 566.0\left[\mathrm{M}_{\mathrm{Br}}-\mathrm{Thi}\right]^{+}, 534.0\left[\mathrm{M}_{\mathrm{Cl}}-\mathrm{NEt}_{2}\right]^{+}, 496.0\left[\mathrm{M}_{\mathrm{Cl}}-\right. \\
& \mathrm{COD}]^{+}, \quad 458.9 \quad\left[\mathrm{M}_{\mathrm{Br}}-\mathrm{COD}-\mathrm{Thi}\right]^{+}, \quad 269.0 \\
& {\left[\mathrm{Thi}_{2} \mathrm{PNEt}_{2}\right]^{+}, 197.0\left[\mathrm{Thi}_{2} \mathrm{P}\right]^{+}, 115.0[\mathrm{PThi}]^{+}, 91.0} \\
& {[\mathrm{Tol}-\mathrm{H}]^{+} .}
\end{aligned}
$$

\subsubsection{Synthesis of $\left[\left(\mathrm{SC}_{4} \mathrm{H}_{3}\right)_{2}\left(\mathrm{NEt}_{2}\right) \mathrm{PAuCl}\right](18)$}<smiles>CCNP(Cl)(Cl)(c1cccs1)c1cccs1</smiles>

Unfortunately, only a few crystals could be isolated.

\subsubsection{Synthesis of $\mathrm{Thi}_{2} \mathrm{PCl}(20)$}<smiles>ClP(c1cccs1)c1cccs1</smiles>

Through a solution of $12(21.3 \mathrm{~g}, 79 \mathrm{mmol}, 25.3 \mathrm{~mL})$ in pentane $(500 \mathrm{~mL})$ gaseous $\mathrm{HCl}$ was passed at $0{ }^{\circ} \mathrm{C}$ for $30-45$ minutes. The precipitated $\mathrm{Et}_{2} \mathrm{NH} \cdot \mathrm{HCl}$ was filtered 
off and washed with pentane $(3 \times 20 \mathrm{~mL})$. The solvents were removed under reduced pressure and the pure product obtained as slightly yellow crystals. ${ }^{[101]}$

Yield: $18.04 \mathrm{~g}, 98 \% . \mathrm{M}=232.69 \mathrm{~g} / \mathrm{mol}$

${ }^{1} \mathbf{H}$ NMR $\left(300.13 \mathrm{MHz}, \mathrm{C}_{6} \mathrm{D}_{6}\right): \quad \delta \quad 7.23 \quad\left(\mathrm{ddd}, \quad{ }^{3} J_{\mathrm{PH}}=6.7 \mathrm{~Hz}, \quad{ }^{3} J_{\mathrm{HH}}=3.5 \mathrm{~Hz}\right.$, $\left.{ }^{4} J_{\mathrm{HH}}=1.1 \mathrm{~Hz}, 2 \mathrm{H}, \mathrm{H}_{3}\right), 7.03\left(\mathrm{dd},{ }^{3} J_{\mathrm{HH}}=4.9 \mathrm{~Hz}\right.$, $\left.{ }^{4} J_{\mathrm{HH}}=1.1 \mathrm{~Hz}, 2 \mathrm{H}, \mathrm{H}_{5}\right), 6.57\left(\mathrm{ddd},{ }^{3} J_{\mathrm{HH}}=5.0 \mathrm{~Hz}\right.$, $\left.{ }^{3} J_{\mathrm{HH}}=3.5 \mathrm{~Hz},{ }^{4} J_{\mathrm{PH}}=1.6 \mathrm{~Hz}, 2 \mathrm{H}, \mathrm{H}_{4}\right)$.

${ }^{13} \mathbf{C}\left\{{ }^{1} \mathbf{H}\right\}$ NMR (75.48 MHz, MHz, $\left.\mathrm{C}_{6} \mathrm{D}_{6}\right)$ :

$$
\begin{aligned}
& \delta 139.89\left(\mathrm{~d},{ }^{1} J_{\mathrm{PC}}=47.4 \mathrm{~Hz}, \mathrm{C}_{2}\right), 135.48(\mathrm{~d}, \\
& \left.{ }^{2} J_{\mathrm{PC}}=36.1 \mathrm{~Hz}, \mathrm{C}_{3}\right), 133.19\left(\mathrm{~d},{ }^{3} J_{\mathrm{PC}}=1.3 \mathrm{~Hz}, \mathrm{C}_{5}\right), \\
& 127.03\left(\mathrm{~d},{ }^{3} J_{\mathrm{PC}}=8.5 \mathrm{~Hz}, \mathrm{C}_{4}\right) .
\end{aligned}
$$

${ }^{31} \mathbf{P}\left\{{ }^{1} \mathbf{H}\right\}$ NMR $\left(121.49 \mathrm{MHz}, \mathrm{C}_{6} \mathrm{D}_{6}\right): \delta 53.42(\mathrm{~s})$.

\subsubsection{Synthesis of $\mathrm{Thi}_{2} \mathrm{PH}(19)$}

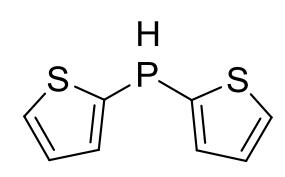

\section{Route A}

K-selectride or DIBAL (5 mmol) was added to 20 (1 g, 5 mmol) in $\mathrm{Et}_{2} \mathrm{O}$ (50 mL) within $30 \mathrm{~min}$ at $-78^{\circ} \mathrm{C}$. The reaction mixture was stirred overnight and precipitates removed (P3 frit, Celite), rinsed with $\left(3 \mathrm{x} \mathrm{Et}_{2} \mathrm{O}, 4 \mathrm{~mL}\right)$ and solvents removed under vacuo. Major product: 21.

Procedure was adapted for $\mathrm{LiBH}_{4}$. The addition in portion yielded 19.

\section{Route B}

20 (7.05 g, $30.4 \mathrm{mmol}, 1 \mathrm{eq})$ in $\mathrm{Et}_{2} \mathrm{O}(25 \mathrm{~mL})$ was added slowly to a solution of DIBAL (4.75 g, $33.4 \mathrm{mmol}, 1.1$ eq.) in $\mathrm{Et}_{2} \mathrm{O}(30 \mathrm{~mL})$ at $-78^{\circ} \mathrm{C}$ and allowed to warm up overnight. The formed salts were filtered ( $\mathrm{P} 4$ frit, Celite), washed with $\mathrm{Et}_{2} \mathrm{O}(3 \times 5 \mathrm{~mL})$ and all volatile compound removed under vacuo. The reaction yielded $\mathbf{1 9}$ and the byproduct 21 . 
${ }^{1}$ H NMR (300.13 MHz, $\left.\mathrm{C}_{6} \mathrm{D}_{6}\right): \quad \delta 6.95\left(\mathrm{dd},{ }^{3} \mathrm{~J}_{\mathrm{HH}}=3.6 \mathrm{~Hz},{ }^{4} J_{\mathrm{HH}}=1.2 \mathrm{~Hz}, 2 \mathrm{H}, \mathrm{H}_{3}\right)$, $6.73\left(\mathrm{dd},{ }^{3} J_{\mathrm{HH}}=5.1 \mathrm{~Hz},{ }^{4} J_{\mathrm{HH}}=1.2 \mathrm{~Hz}, 2 \mathrm{H}, \mathrm{H}_{5}\right)$, $6.64\left(\mathrm{dd},{ }^{3} J_{\mathrm{HH}}=5.1 \mathrm{~Hz},{ }^{3} J_{\mathrm{HH}}=3.6 \mathrm{~Hz}, 2 \mathrm{H}, \mathrm{H}_{4}\right)$, $5.46\left(\mathrm{~d},{ }^{1} J_{\mathrm{PH}}=222.0 \mathrm{~Hz}, 1 \mathrm{H}, \mathrm{PH}\right)$.

${ }^{1} \mathbf{H}\left\{{ }^{31} \mathbf{P}\right\}$ NMR $\left(300.13 \mathrm{MHz}, \mathrm{CDCl}_{3}\right): \delta \quad 7.31 \quad\left(\mathrm{ddd}, \quad{ }^{3} J_{\mathrm{HH}}=3.5 \mathrm{~Hz}, \quad{ }^{4} J_{\mathrm{HH}}=1.2 \mathrm{~Hz}\right.$, $\left.{ }^{4} J_{\mathrm{HH}}=1.1 \mathrm{~Hz}, 2 \mathrm{H}, \mathrm{H}_{3}\right), 7.16\left(\mathrm{~m}, 2 \mathrm{H}, \mathrm{H}_{5}\right), 7.01$ $\left(\mathrm{m}, 2 \mathrm{H}, \mathrm{H}_{4}\right), 5.54(\mathrm{~m}, 1 \mathrm{H}, \mathrm{PH})$.

${ }^{13} \mathbf{C}\left\{{ }^{1} \mathbf{H}\right\}$ NMR (75.48 MHz, MHz, $\left.\mathrm{C}_{6} \mathrm{D}_{6}\right)$ :

$\delta 135.54\left(\mathrm{~d},{ }^{1} J_{\mathrm{PC}}=120.8 \mathrm{~Hz}, \mathrm{C}_{2}\right), 130.93\left(\mathrm{~s}, \mathrm{C}_{5}\right)$, $127.72\left(\mathrm{~m}, \mathrm{C}_{3}\right), 127.55\left(\mathrm{~m}, \mathrm{C}_{4}\right)$.

${ }^{13} \mathbf{C}\left\{{ }^{1} \mathbf{H}\right\}$ NMR $\left(75.48 \mathrm{MHz}, \mathrm{CDCl}_{3}\right): \delta 35.49 \quad\left(\mathrm{~d},{ }^{1} J_{\mathrm{PC}}=133.7 \mathrm{~Hz}, \mathrm{C}_{2}\right), 135.30 \quad(\mathrm{~d}$, $\left.{ }^{2} J_{\mathrm{PC}}=27.5 \mathrm{~Hz}, \mathrm{C}_{3}\right), 127.12\left(\mathrm{~d},{ }^{3} J_{\mathrm{PC}}=8.4 \mathrm{~Hz}, \mathrm{C}_{4}\right)$, $123.52\left(\mathrm{~m}, \mathrm{C}_{5}\right)$.

${ }^{31}$ P NMR (78.48 MHz, $\left.\mathrm{C}_{6} \mathrm{D}_{6}\right): \quad \delta-90.63\left(\mathrm{dt},{ }^{1} J_{\mathrm{PH}}=227.7 \mathrm{~Hz},{ }^{3} J_{\mathrm{PH}}=5.9 \mathrm{~Hz}\right)$.

${ }^{31} \mathbf{P}\left\{{ }^{1} \mathbf{H}\right\}$ NMR $\left(78.48 \mathrm{MHz}, \mathrm{CDCl}_{3}\right): \delta-90.24\left(\mathrm{dt},{ }^{1} J_{\mathrm{PH}}=229.4 \mathrm{~Hz},{ }^{3} J_{\mathrm{PH}}=6.0 \mathrm{~Hz}\right)$.

ESI-MS (Et $\left.\mathbf{E}_{\mathbf{2}} \mathbf{O}\right): \mathrm{m} / \mathrm{z}(\%): \quad 197[\mathrm{M}]^{-}(100), 213[\mathrm{M}+\mathrm{O}](60), 232[\mathrm{M}+\mathrm{Cl}](35)$

\subsubsection{Characterization of $\mathrm{Thi}_{4} \mathrm{P}_{2}(21)$}

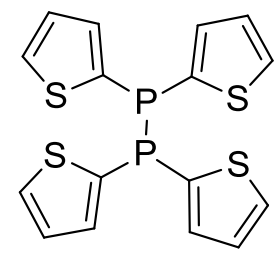

Crystals of $\mathbf{2 1}$ were isolated from a reduction reaction and NMR experiments performed. An initial XRD-experiment verified the cell parameter.

${ }^{1}$ H NMR (400.13 MHz, $\left.{ }_{6} \mathrm{D}_{6}\right): \quad \delta 7.19\left(\mathrm{dd},{ }^{3} J_{\mathrm{HH}}=3.5 \mathrm{~Hz},{ }^{4} J_{\mathrm{HH}}=1.1 \mathrm{~Hz}, 4 \mathrm{H}, \mathrm{H}_{3}\right)$, $7.03\left(\mathrm{dd},{ }^{3} J_{\mathrm{HH}}=5.0 \mathrm{~Hz},{ }^{4} J_{\mathrm{HH}}=1.1 \mathrm{~Hz}, 4 \mathrm{H}, \mathrm{H}_{5}\right)$, $6.64\left(\mathrm{dd},{ }^{3} J_{\mathrm{HH}}=5.0 \mathrm{~Hz},{ }^{3} J_{\mathrm{HH}}=3.5 \mathrm{~Hz}, 4 \mathrm{H}, \mathrm{H}_{4}\right)$. 
${ }^{1} \mathbf{H}\left\{{ }^{31} \mathbf{P}\right\}$ NMR $\left(400.13 \mathrm{MHz}, \mathrm{CDCl}_{3}\right): \delta 7.51\left(\mathrm{~m}, 4 \mathrm{H}, \mathrm{H}_{3}\right), 7.19\left(\mathrm{dd},{ }^{3} J_{\mathrm{HH}}=3.5 \mathrm{~Hz}\right.$, $\left.{ }^{4} J_{\mathrm{HH}}=1.1 \mathrm{~Hz}, 4 \mathrm{H}, \mathrm{H}_{5}\right), 6.96\left(\mathrm{dd},{ }^{3} J_{\mathrm{HH}}=4.9 \mathrm{~Hz}\right.$, $\left.{ }^{3} J_{\mathrm{HH}}=3.5 \mathrm{~Hz}, 4 \mathrm{H}, \mathrm{H}_{4}\right)$.

${ }^{13} \mathbf{C}\left\{{ }^{1} \mathbf{H}\right\}$ NMR (75.48 MHz, $\left.\mathrm{C}_{6} \mathrm{D}_{6}\right): \delta 135.21 \quad\left(\mathrm{~d}, \quad{ }^{2} J_{\mathrm{PC}}=27.5 \mathrm{~Hz}, \mathrm{C}_{3}\right), 131.94 \quad(\mathrm{~d}$, $\left.{ }^{1} J_{\mathrm{PC}}=24.2 \mathrm{~Hz}, \mathrm{C}_{2}\right), 131.10\left(\mathrm{~m}, \mathrm{C}_{5}\right), 127.41(\mathrm{~m}$, $\left.\mathrm{C}_{4}\right)$.

${ }^{13} \mathbf{C}\left\{{ }^{1} \mathbf{H}\right\}$ NMR $\left(75.48 \mathrm{MHz}, \mathrm{CDCl}_{3}\right): \delta 135.36\left(\mathrm{~d},{ }^{3} \mathrm{~J}_{\mathrm{PC}}=15.8 \mathrm{~Hz}, \mathrm{C}_{5}\right), 132.16\left(\mathrm{~m}, \mathrm{C}_{3}\right)$, $131.87\left(\mathrm{~d},{ }^{1} J_{\mathrm{PC}}=23.6 \mathrm{~Hz}, \mathrm{C}_{2}\right), 127.54\left(\mathrm{~m}, \mathrm{C}_{4}\right)$.

${ }^{31} \mathbf{P}\{1 \mathbf{H}\}$ NMR $\left(78.48 \mathrm{MHz}, \mathrm{C}_{6} \mathrm{C}_{6}\right): \delta-38.61(\mathrm{~s})$.

${ }^{31} \mathbf{P}\{1 \mathbf{H}\}$ NMR $\left(78.48 \mathrm{MHz}, \mathrm{CDCl}_{3}\right): \quad \delta-36.66(\mathrm{~s})$.

ESI-MS $\left(\mathbf{E t}_{2} \mathbf{O}\right): \mathrm{m} / \mathrm{z}(\%): \quad 393.9\left[\mathrm{M}^{-}(23)\right.$.

\subsubsection{Characterization of $\mathrm{Thi}_{2} \mathrm{P}(\mathrm{O}) \mathrm{OH}(22)$}<smiles>O=P(O)(c1cccs1)c1cccs1</smiles>

$\mathrm{Thi}_{2}(\mathrm{O}) \mathrm{OH}(\mathbf{2 2})$ was isolated as a byproduct in the reaction to form 19. A few single crystals of $\mathbf{2 2}$ were isolated from aqueous workup and XRD experiments performed. ${ }^{31} \mathbf{P}\{1 \mathbf{H}\}$ NMR $\left(78.48 \mathrm{MHz}, \mathrm{C}_{6} \mathrm{D}_{6}\right): \quad \delta 22.35\left(20.88(\text { thi })_{2} \mathrm{P}(\mathrm{O}) \mathrm{Cl}\right)$

\subsubsection{Synthesis of Furfuryl chloride}

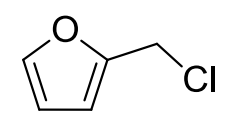

\section{Route A:}

To a solution of furfuryl alcohol $(2.0 \mathrm{~mL}, 23 \mathrm{mmol}, 1$ eq.) in DCM (35 ml) thionyl chloride $(1.7 \mathrm{~mL}, 24 \mathrm{mmol}, 1 \mathrm{eq})$ was added drop wise and the reaction mixture turned 
blue. After the addition of $\mathrm{NEt}_{3}(3.3 \mathrm{~mL}, 24 \mathrm{mmol}, 1 \mathrm{eq})$ in small portions the mixture was stirred for $24 \mathrm{~h}$.

The procedure was repeated at dry ice cooling as well as a combined addition of thionyl chloride and $\mathrm{NEt}_{3}$ to furfuryl alcohol. From none of these reactions furfuryl chloride could have been isolated.

\section{Route B:}

Solution I: Thionyl chloride $(5.5 \mathrm{~mL}, 75 \mathrm{mmol})$ and benzotriazole $(8.93 \mathrm{~g}, 75 \mathrm{mmol})$ were dissolved in DCM (50 mL).

To a solution of furfuryl alcohol $(0.18 \mathrm{ml}, 2.0 \mathrm{mmol}, 1$ eq.) in DCM (40 mL) solution I (3.75 mL, $2.5 \mathrm{mmol}, 1.3$ eq.) was added at $0{ }^{\circ} \mathrm{C}$. The reaction mixture turned yellow and a colourless precipitate was filtered off after $20 \mathrm{~min}$. After evaporation of the solvent the residual filtrate turned black. The product could not be identified.

Varying the concentrations of the starting materials did not improve the outcome of the reaction.

\section{Route C:}

A mixture of PPh3 (130 mmol, $34.1 \mathrm{~g}, 1.3 \mathrm{eq}$ ), furfuryl alcohol (100 mmol, $8.7 \mathrm{~mL}$, $1 \mathrm{eq})$ in $\mathrm{CCl}_{4}(90 \mathrm{~mL})$ was heated to reflux for one hour. After cooling to RT $n$-pentane $(100 \mathrm{~mL})$ was added and a precipitate was formed. The precipitate was filtered and washed a few times with $n$-pentane (total $50 \mathrm{~mL}$ ). The solvents were removed under reduced pressure. A distillation at 12 mbar yielded the product as a colourless liquid.

Yield: $3.5 \mathrm{~mL}, 35 \%$.b.p.: $32{ }^{\circ} \mathrm{C}(12$ mbar $)\left[\right.$ Lit. ${ }^{[142]}: 28-30{ }^{\circ} \mathrm{C}(6$ mbar $\left.)\right]$

${ }^{1}$ H NMR (300.13 MHz, $\left.\mathbf{C}_{6} \mathbf{D}_{6}\right): \quad \delta 6.93\left(\mathrm{~s}, 1 \mathrm{H}, \mathrm{H}_{\text {aryl }}\right), 5.86\left(\mathrm{~m}, 2 \mathrm{H}, \mathrm{H}_{\text {aryl }}\right), 4.02(\mathrm{~s}$, $\left.2 \mathrm{H}, \mathrm{CH}_{2}\right)$.

${ }^{13}$ C NMR (75.48 MHz, $\left.\mathbf{C}_{6} \mathbf{D}_{6}\right): \quad \delta(\mathrm{ppm}) 143.3\left(\mathrm{C}_{\text {aryl }}\right), 110.7\left(\mathrm{C}_{\text {aryl }}\right), 109.5\left(\mathrm{C}_{\text {aryl }}\right)$, $37.11\left(\mathrm{CH}_{2}\right)$.

ESI-MS (Et $\left.{ }_{2} \mathbf{O}\right):$ m/z (\%): $\quad 116.9(32)[\mathrm{M}]^{+}, 81(23)[\mathrm{M}-\mathrm{Cl}]^{+}, 54(44)$. 


\subsubsection{Synthesis of Bis(furfuryl)phenylphosphane}

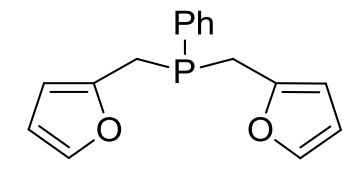

To phenylphosphin (1.65 mL, $15 \mathrm{mmol}, 1.0 \mathrm{eq})$ in $\mathrm{Et}_{2} \mathrm{O}(20 \mathrm{~mL}) n$-BuLi (2.3 eq.) was added dropwise at $0^{\circ} \mathrm{C}$. After $30 \mathrm{~min}$ furfurylchloride $(3.0 \mathrm{~mL}, 30 \mathrm{mmol}, 2$ eq.) was added, stirred for $2 \mathrm{~h}$ and filtrated (2x, Celite). Removal of the solvent yielded a brownish oil.

The work up was changed: The residue was solved in $n$-pentane and placed in a supersonic bath.

${ }^{1}$ H NMR (300.13 MHz, $\left.\mathbf{C}_{6} \mathbf{D}_{6}\right): \quad \delta 4.02\left(\mathrm{~s}, \mathrm{CH}_{2}\right)$, 5.69-6.12 $(\mathrm{m}), 6.82-6.98(\mathrm{~m})$.

${ }^{31}$ P NMR (121.49 MHz, $\mathbf{C}_{6} \mathbf{D}_{6}$ ): $\quad \delta-23.63$ (-26.8, unindentified sideproduct).

ESI-MS (Et $\left.{ }_{2} \mathbf{O}\right):$ m/z (\%): $\quad 116.9(32)[\mathrm{M}]^{+}, 81(23)[\mathrm{M}-\mathrm{Cl}]^{+}, 54(44)$.

\subsubsection{Synthesis $\left[\left\{(\text { FurPh })_{2} \mathbf{P}_{2}\right\} \mathrm{Au}_{2} \mathrm{Cl}_{2}(\mathrm{FurPhPH})\right](23)$}

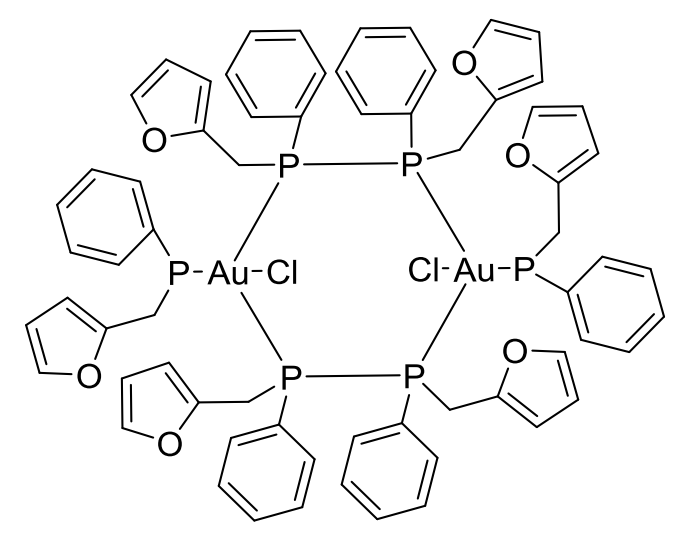

Bis(furfuryl)phenylphosphane (crude product, $0.12 \mathrm{~g}$ ) and $\mathrm{AuCl}\left(\mathrm{SMe}_{2}\right)$ were dissolved in toluene $(10 \mathrm{~mL})$ and stored at $-44^{\circ} \mathrm{C}$. Single suitable crystals of 23 were isolated.

Crystallization attempts with $\mathrm{NiCl}_{2}$ and $\mathrm{PbCl}_{2}$ were inconclusive until today. 


\subsubsection{Synthesis of Furfuryloxy- and 2-thienylmethoxy substituted phosphonous diesters}

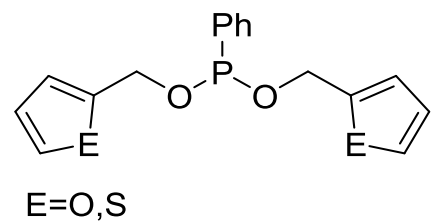

\section{Route A:}

To a solution of alcohol (40 mmol, 2 eq.) and $\mathrm{NEt}_{3}(5.5 \mathrm{~mL}, 40 \mathrm{mmol}, 2 \mathrm{eq})$ in $\mathrm{Et}_{2} \mathrm{O}$ (10 mL) $\mathrm{PhPCl}_{2}\left(2.7 \mathrm{~mL}, 20 \mathrm{mmol}, 2\right.$ eq.) was added dropwise at $0^{\circ} \mathrm{C}$. The reaction mixture was stirred for $48 \mathrm{~h}$, filtered and volatile compound in vacuo removed. The residue was solved in $n$-pentane and filtered. Both compounds were isolated as crude oils.

\section{Route B:}

To $\mathrm{PhPCl}_{2}(1.4 \mathrm{~mL}, 10 \mathrm{mmol}, 1$ eq. $)$ in $\mathrm{Et}_{2} \mathrm{O}(10 \mathrm{~mL})$ a solution of the alcohol (20 mmol, 2 eq.) and $\mathrm{NEt}_{3}(2.8 \mathrm{~mL}, 20 \mathrm{mmol}, 2$ eq.) was added slowly. Subsequently the reaction mixture was heated to reflux for $2 \mathrm{~h}$, filtered and the residue dissolved in $n$ pentane. Both compounds were isolated as crude oils.

\section{Furfuryloxy substituted phosphonous diester}

ESI-MS (Et $\left.\mathbf{E}_{2} \mathbf{O}\right):$ m/z (\%): $\quad 302(1)[\mathrm{M}]^{+}, 222(30)[\mathrm{M}-\mathrm{fur}]^{+}, 126$ (24), 97 (68),

$$
81 \text { (100) [fur]. }
$$

\section{2-Thienylmethoxy substituted phosphonous diester}

ESI-MS (Et $\left.\mathbf{E t}_{2} \mathbf{O}\right): \mathrm{m} / \mathrm{z}(\%): \quad 334(10)[\mathrm{M}]^{+}, 253$ (30), 238 (96) [M-thiMe], 194 (100), 173 (40).

${ }^{31} \mathrm{P}$ and ${ }^{1} \mathrm{H}$ NMR spectra showed a mixture of products for both compounds. 



\section{Crystallographic Section}

\subsection{Crystal Application}

Single crystals were taken from the mother liquor using standard Schlenk techniques and placed in perfluorinated polyether oil on a microscope slide. An appropriately sized crystal of high quality was selected under a polarization microscope (for detection of twinning and the presence of satellites) with help of the X-TEMP2 cooling device. ${ }^{[58]}$ It was mounted on a glass fiber or MiTEGEN $^{\odot}$ MICROMOUNT glued to the magnetic pin of the goniometer head in a way that it was completely coated with the perfluorinated polyether oil. ${ }^{[4]}$ Oil and crystal were shocked-cooled in the cold gas stream of an open flow nitrogen cooling device attached to the diffractometer. The amorphous frozen oil served as glue and protected the sensitive compounds along with the nitrogen gas stream from moisture and oxygen.

\subsection{Data Collection and Processing}

All compounds were measured on a BRUKER D 8 Goniometer platform, equipped with an APEX II CCD X-ray detector. The compounds were measured using either an $\mathrm{I} \mu \mathrm{S}^{[84]}$ or on a rotating anode turbo X-ray source. Both use mirrors as monochromator optics, which supplies very intense and brilliant $\operatorname{MoK}_{\alpha}$ radiation $(\lambda=0.71073 \AA$ ). All crystals were centered optically using a video camera after being placed on the diffractometer. All data sets measured at $100 \mathrm{~K}$ and Mo wavelength, if not otherwise stated.

Data set of 9 was measured on a Bruker three circle diffractometer equipped with a SMART 6000 detector using $\mathrm{CuK}_{\alpha}$ radiation $(\lambda=1.54178 \AA)$. The Data was measured at $100 \mathrm{~K}$.

Data of 9 were collected using synchrotron radiation with a wavelength of $0.3936 \AA$ at sector 15 ID-B of ChemMatCARS at the APS, Argonne, USA. The beam line is equipped with a BRUKER D8 Goniometer platform, and the diffracted beam was collected on a APEX II CCD X-ray detector. Data sets were measured at $12 \mathrm{~K}$.

Data collection was controlled with the APEX2 software package. ${ }^{[153]}$ A test run (matrix scan) was recorded prior to each experiment to check the crystal quality, to get a 
rough estimate of the cell parameters, and to determine the optimum exposure time. All scans of the data collections were performed in an $\omega$-scan mode with a step-width of $0.3^{\circ}$ or $0.5^{\circ}$ at fixed $\phi$-angles.

The determination of the unit cells and orientation matrices were performed with the tools supplied in the APEX2 software package. The collected frames were integrated with SAINT ${ }^{[154]}$ using the $3 \mathrm{~d}$ profiling method described by Kabsch. ${ }^{[155]}$ All data sets were corrected for absorption and scaled using SADABS ${ }^{[156]}$ or TwINABS. ${ }^{[157]}$ XPREP $^{[158]}$ was used to determine the space group prior to the absorption correction, as this is crucial for a correct treatment. SADABS and TWINABS refine an empirical model function by symmetry-equivalent reflections. Setup of the files for structure solution and refinement was performed with XPREP.

\subsection{Structure Solution and Refinement}

The structures were solved with direct methods or Patterson superposition procedure using SHELXS. ${ }^{[159]}$ Data were merged according to the determined symmetry with SHELXL. ${ }^{[159]}$ All refinements were performed on $F^{2}$ with SHELXL implemented in the SHELXLE GUI. ${ }^{[160]}$ If not stated otherwise, the hydrogen atoms of the compounds were refined isotropically on calculated positions using a riding model. The positions were geometrically optimized and the $U_{\text {iso }}$ were constrained to $1.2 U_{\text {eq }}$ ( 1.5 for methyl carbon) of the pivot atom. The position of certain hydrogen atoms (e.g. OH groups) were found with difference Fourier analysis of the rest electron density. If not stated otherwise, the hydrogen bond lengths were restrained to a sensible value and the $U_{\text {iso }}$ were constrained as mentioned above. In all refinements the function $M\left(p_{i}, k\right)($ Eq. 7-1) was minimized using the weights $w$ defined in Eq. 7-2.

Eq. 7-1.

$$
M\left(p_{i}, k\right)=\sum w\left[k\left|F_{\text {obs }}\right|^{2}-\left|F_{\text {calc }}\right|^{2}\right]^{2}=\min
$$

Eq. 7-2.

$$
w^{-1}=\sigma^{2} F_{\mathrm{obs}}^{2}+(g 1 \cdot P)^{2}+g 2 \cdot P \quad \text { with } \quad P=\left(\frac{F_{\mathrm{obs}}^{2}+2 F_{\mathrm{calc}}^{2}}{3}\right)
$$

The results of the refinements were verified by comparison of the calculated and the observed structure factors. Commonly used criteria are the residuals $R 1$ (Eq. 7-3) and $w R 2$ (Eq. 7-4). The $w R 2$ is more significant, because the model is refined against $F^{2}$. 
$\begin{array}{ll}\text { Eq. 7-3. } & R 1=\frac{\sum|| F_{\mathrm{obs}}|-| F_{\text {calc }}||}{\sum\left|F_{\mathrm{obs}}\right|} \\ \text { Eq. 7-4. } & w R 2=\sqrt{\frac{\sum w\left(F_{\mathrm{obs}}^{2}-F_{\mathrm{calc}}^{2}\right)^{2}}{\sum w\left(F_{\mathrm{obs}}^{2}\right)^{2}}}\end{array}$

Additionally, the goodness of fit (GoF or S), a figure or merit showing the relation between deviation of $F_{\text {calc }}$ from $F_{\text {obs }}$ and the over-determination of refined parameters is calculated (Eq. 7-5).

Eq. 7-5. $\quad S=\sqrt{\frac{\sum\left(w\left(F_{\mathrm{obs}}^{2}-F_{\mathrm{calc}}^{2}\right)^{2}\right)}{(n-p)}}$

The residual densities from difference Fourier analysis should be low. Due to the model restrictions the residuals are normally found in the bonding regions. Higher residuals for heavy scatterers are acceptable as they arise mainly from absorption effects and Fourier truncation errors due to the limited recorded resolution range. The highest peak and deepest hole from difference Fourier analysis are listed in the crystallographic tables.

Additionally, the orientation, size and ellipticity of the ADP show the quality of the model. Ideally, the ADPs should be oriented perpendicular to the bonds, be equal in size and show little ellipticity. All graphics were generated and plotted with the XSHELL or MERCURY $^{[161]}$ software and at $50 \%$ probability level.

\subsection{Treatment of Disorder}

Structures containing disordered fragments were refined using constraints and restraints. The geometries of chemically equivalent but crystallographically independent fragments can be fitted to each other by distance restraints. Especially the 1,2 distances (bond lengths) and 1,3 distances (bond angles) are set to be equal within their effective standard deviations. This is helpful for refining disordered positions as the averaging of equivalent fragments implements chemical information and stabilizes the refinement.

Restraints affecting the anisotropic displacement parameters are often essential for the anisotropic refinement of disordered atomic positions. The rigid bond restraints (DELU in SHELXL) ${ }^{[162]}$ fit the components of the anisotropic displacement parameters 
along the bonds within esds. Similarity restraints (SIMU in SHELXL) ${ }^{[162]}$ adjust the ADPs of neighbouring atoms within a certain radius to be equal according to their esds.

The thienyl groups are refined using 1,2- and 1,-3-distance (SADI, SAME, respectively) and rigid bond (SIMU, DELU and RIGU) restraints to stabilize the model refinement. An exemplary pattern is given below to describe the positional disorder of S1 and C2:
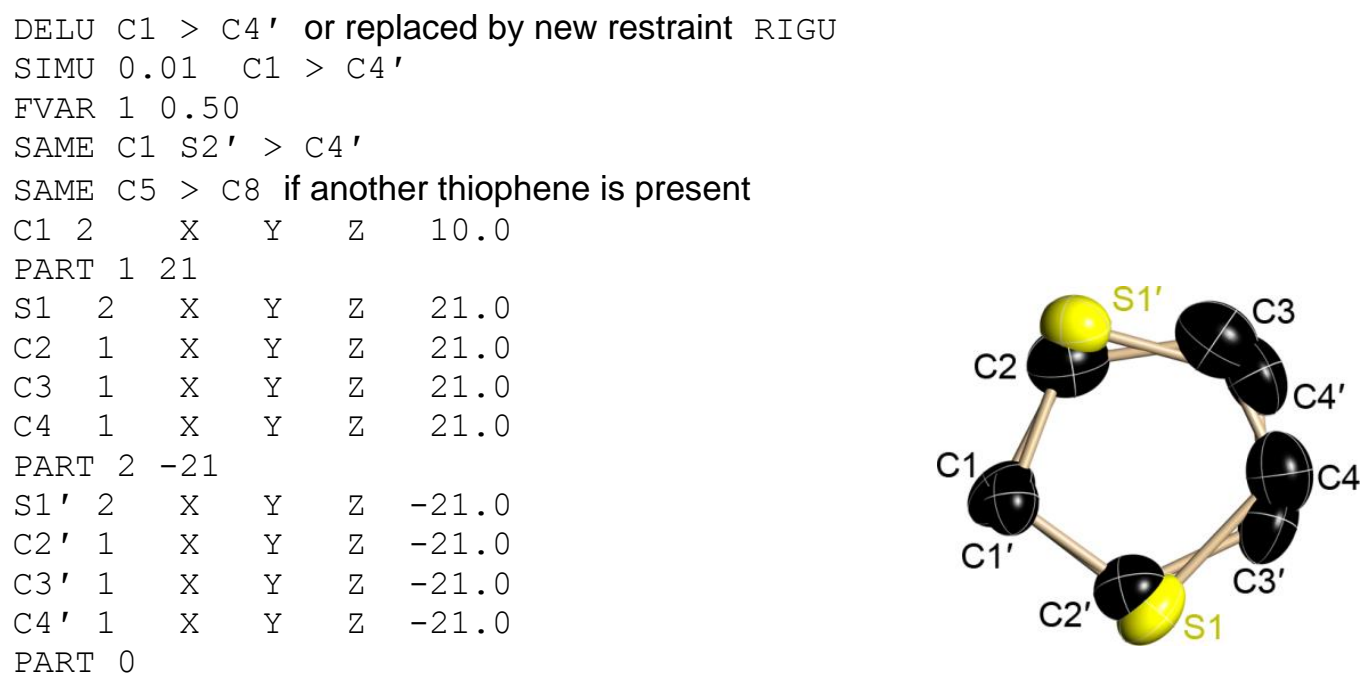


\subsection{Crystallographic Details}

The crystallographic data for the compounds $\mathbf{2}$ and $\mathbf{5}$ have been published in my diploma thesis. Minor changes to improve the refinement were applied before the structures were deposited in the CSD. CCDC numbers are given in Table 6-1.

Table 6-1. CCDC numbers of previously published structures.

\begin{tabular}{lll}
\hline \multicolumn{2}{l}{ Molecule } & CCDC No. \\
\hline $\mathbf{2}$ & {$\left[(\mathrm{THF})_{2} \mathrm{Li}\left(\mathrm{C}_{4} \mathrm{H}_{3} \mathrm{~S}\right)\right]_{2}$} & 833248 \\
$\mathbf{5}$ & {$\left[(\right.$ PMDETA $\left.) \mathrm{Li}\left(\mathrm{C}_{4} \mathrm{H}_{3} \mathrm{~S}\right)\right]$} & 833250 \\
\hline
\end{tabular}




\subsection{1 $\quad\left[\left(\mathrm{Et}_{2} \mathrm{O}\right) \mathrm{Li}\left(\mathrm{C}_{4} \mathrm{H}_{3} \mathrm{~S}\right)\right]_{4}(\mathbf{1})$}

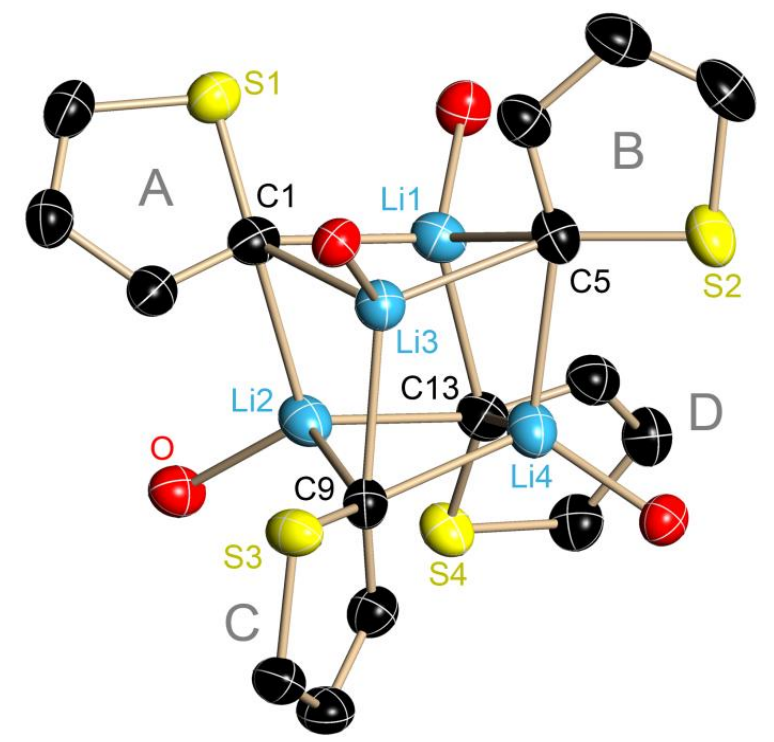

Scheme 6-1. Asymmetric unit of $\left[\left(\mathrm{Et}_{2} \mathrm{O}\right) \mathrm{Li}\left(\mathrm{C}_{4} \mathrm{H}_{3} \mathrm{~S}\right)\right]_{4}(\mathbf{1})$. The hydrogen atoms are omitted for clarity.

Disorder of the thienyl and ethyl groups are refined with distance and ADP restraints

Table 6-2. Crystallographic data for $\left[\left(\mathrm{Et}_{2} \mathrm{O}\right) \mathrm{Li}\left(\mathrm{C}_{4} \mathrm{H}_{3} \mathrm{~S}\right)\right]_{4}(\mathbf{1})$.

\begin{tabular}{ll|ll}
\hline CCDC no. & 833247 & $\rho_{\text {calc }}\left[\mathrm{Mg} / \mathrm{m}^{3}\right]$ & 1.162 \\
Empirical formula & $\mathrm{C}_{32} \mathrm{H}_{52} \mathrm{Li}_{4} \mathrm{O}_{4} \mathrm{~S}_{4}$ & $\mu\left[\mathrm{mm}^{-1}\right]$ & 0.284 \\
Formula weight $[\mathrm{g} / \mathrm{mol}]$ & 656.74 & $\mathrm{~F}(000)$ & 704 \\
Crystal system & Triclinic & $\Theta$ range $\left[{ }^{\circ}\right]$ & 1.18 to 26.39 \\
Space group & $P \overline{1}$ & Reflections collected & 44903 \\
$a[\AA]$ & $10.086(2)$ & Independent reflections & $7676(0.0550)$ \\
$b[\AA]$ & $11.779(2)$ & Completeness to $\Theta_{\max }$ & $99.8 \%$ \\
$c[\AA]$ & & \\
$\alpha\left[^{\circ}\right]$ & $17.970(3)$ & Max. / min. transmission & $0.9703 / 0.8525$ \\
$\beta\left[^{\circ}\right]$ & $85.97(2)$ & Restraints / parameters & $1074 / 594$ \\
$\gamma\left[^{\circ}\right]$ & $73.83(2)$ & GoF & 1.066 \\
$V^{\circ}$ olume $\left[\AA^{3}\right]$ & $66.45(2)$ & $R 1 / w R 2(\mathrm{I}>2 \sigma(\mathrm{I}))$ & $0.0429 / 0.1055$ \\
$\mathrm{Z}$ & $1877.6(6)$ & $R 1 / w R 2($ all data) & $0.0620 / 0.1163$ \\
Crystal size $[\mathrm{mm}]$ & 2 & Diff. peak and hole $\left[\mathrm{e} \AA^{-3}\right]$ & 0.320 and -0.455 \\
\hline
\end{tabular}




\subsection{2 $\left[(\mathrm{DME})_{2} \mathrm{Li}\left(\mathrm{C}_{4} \mathrm{H}_{3} \mathrm{~S}\right)\right]_{2}(3)$}

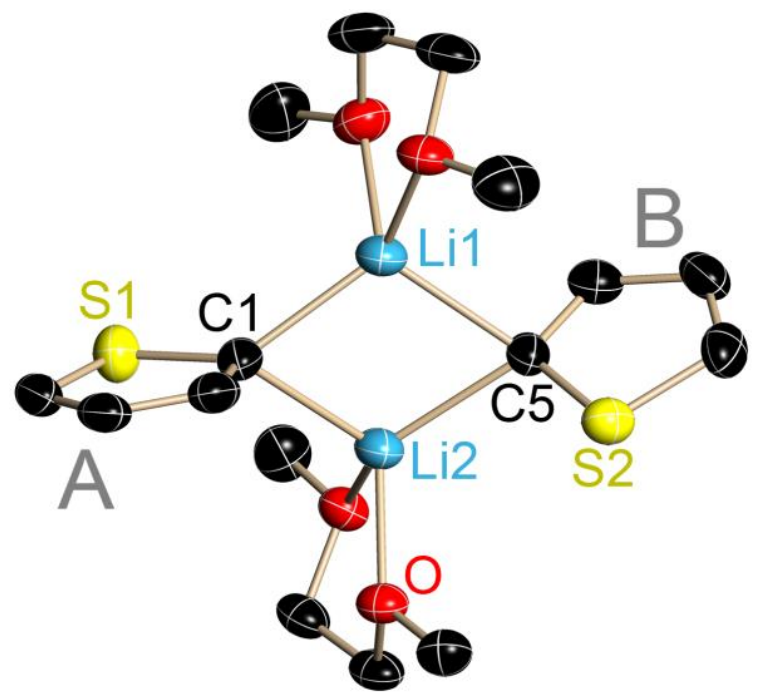

Scheme 6-2. Asymmetric unit of $\left[(\mathrm{DME})_{2} \mathrm{Li}\left(\mathrm{C}_{4} \mathrm{H}_{3} \mathrm{~S}\right)\right]_{2}(3)$. The anisotropic displacement parameters are depicted at the $50 \%$ probability level. The hydrogen atoms are omitted for clarity.

Another polymorph of $\mathbf{3}$ has been published previously. ${ }^{[65]}$

Table 6-3. Crystallographic data for $\left[(\mathrm{DME})_{2} \mathrm{Li}\left(\mathrm{C}_{4} \mathrm{H}_{3} \mathrm{~S}\right)\right]_{2}(\mathbf{3})$.

\begin{tabular}{ll|ll}
\hline CCDC no. & 833249 & $\rho_{\text {calc }}\left[\mathrm{Mg} / \mathrm{m}^{3}\right]$ & 1.159 \\
Empirical formula & $\mathrm{C}_{16} \mathrm{H}_{26} \mathrm{Li}_{2} \mathrm{O}_{4} \mathrm{~S}_{2}$ & $\mu\left[\mathrm{mm}^{-1}\right]$ & 0.271 \\
Formula weight $[\mathrm{g} / \mathrm{mol}]$ & 360.37 & $\mathrm{~F}(000)$ & 384 \\
Crystal system & Triclinic & $\Theta$ range $\left[{ }^{\circ}\right]$ & 2.15 to 26.73 \\
Space group & $P \overline{1}$ & Reflections collected & 20286 \\
$a[\AA]$ & $8.625(2)$ & Independent reflections & $4378(0.0421)$ \\
$b[\AA]$ & $10.471(2)$ & Completeness to $\Theta_{\text {max }}$ & $99.9 \%$ \\
$c[\AA]$ & $12.749(2)$ & Max. / min. transmission & $0.9703 / 0.7841$ \\
$\alpha\left[^{\circ}\right]$ & $76.66(2)$ & Restraints / parameters & $322 / 312$ \\
$\beta\left[^{\circ}\right]$ & $81.73(2)$ & GoF & 1.045 \\
$\gamma\left[^{\circ}\right]$ & $67.47(2)$ & $R 1 / w R 2(\mathrm{I}>2 \sigma(\mathrm{I}))$ & $0.0421 / 0.1108$ \\
Volume $\left[\AA^{3}\right]$ & $1032.9(3)$ & $R 1 / w R 2($ all data $)$ & $0.0538 / 0.1184$ \\
$\mathrm{Z}$ & 2 & Diff. peak and hole $\left[\mathrm{e} \AA^{-3}\right]$ & 0.504 and -0.173 \\
Crystal size $[\mathrm{mm}]$ & $0.20 \times 0.12 \times 0.10$ & & \\
\hline
\end{tabular}




\subsection{3 $\left[\left(\left[(\mathrm{THF})_{2} \mathrm{Li}\left\{\left(\mathrm{C}_{4} \mathrm{H}_{2} \mathrm{~S}\right)-5-\mathrm{Me}\right\}\right]_{2}(6)\right.\right.$}

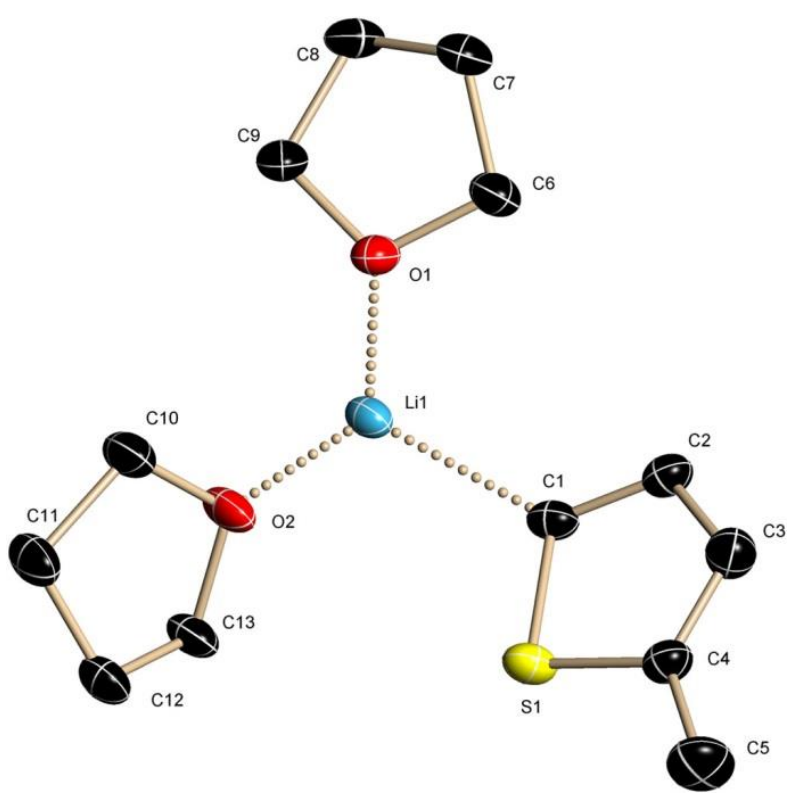

Scheme 6-3. Asymmetric unit of 6. The anisotropic displacement parameters are depicted at the $50 \%$ probability level. The hydrogen atoms are omitted for clarity.

Table 6-4. Crystallographic data for 6.

\begin{tabular}{ll|ll}
\hline ID code & $\mathrm{Mg} \_$kes011 & $\rho_{\text {calc }}\left[\mathrm{Mg} / \mathrm{m}^{3}\right]$ & 1.178 \\
Empirical formula & $\mathrm{C}_{26} \mathrm{H}_{42} \mathrm{Li}_{2} \mathrm{O}_{4} \mathrm{~S}_{2}$ & $\mu\left[\mathrm{mm}^{-1}\right]$ & 0.218 \\
Formula weight $[\mathrm{g} / \mathrm{mol}]$ & 360.37 & $\mathrm{~F}(000)$ & 268 \\
Crystal system & Triclinic & $\Theta$ range $\left[{ }^{\circ}\right]$ & 2.21 to 25.44 \\
Space group & $P \overline{1}$ & Reflections collected & 11660 \\
$a[\AA]$ & $8.625(2)$ & Independent reflections & $2586(0.092)$ \\
$b[\AA]$ & $8.898(3)$ & Completeness to $\Theta_{\max }$ & $99.5 \%$ \\
$c[\AA]$ & $9.552(3)$ & Max. / min. transmission & $0.9703 / 0.4647$ \\
$\alpha\left[^{\circ}\right]$ & $74.924(4)$ & Restraints / parameters & $0 / 155$ \\
$\beta\left[^{\circ}\right]$ & $88.430(4)$ & GoF & 1.142 \\
$\gamma\left[^{\circ}\right]$ & $81.669(4)$ & $R 1 / w R 2(\mathrm{I}>2 \sigma(\mathrm{I}))$ & $0.0771 / 0.1933$ \\
Volume $\left[\AA^{3}\right]$ & $700.3(3)$ & $R 1 / w R 2($ all data) & $0.0876 / 0.1994$ \\
$\mathrm{Z}$ & 1 & Diff. peak and hole $\left[\mathrm{e} \AA^{-3}\right]$ & 0.685 and -0.411 \\
Crystal size $[\mathrm{mm}]$ & $0.10 \times 0.10 \times 0.03$ & & \\
\hline
\end{tabular}




\subsection{4 $\left[\left[(\text { TMEDA }) \operatorname{Li}\left\{\left(\mathrm{C}_{4} \mathrm{H}_{3} \mathrm{~S}\right)-4-\mathrm{Me}\right\}\right]_{2}(8)\right.$}

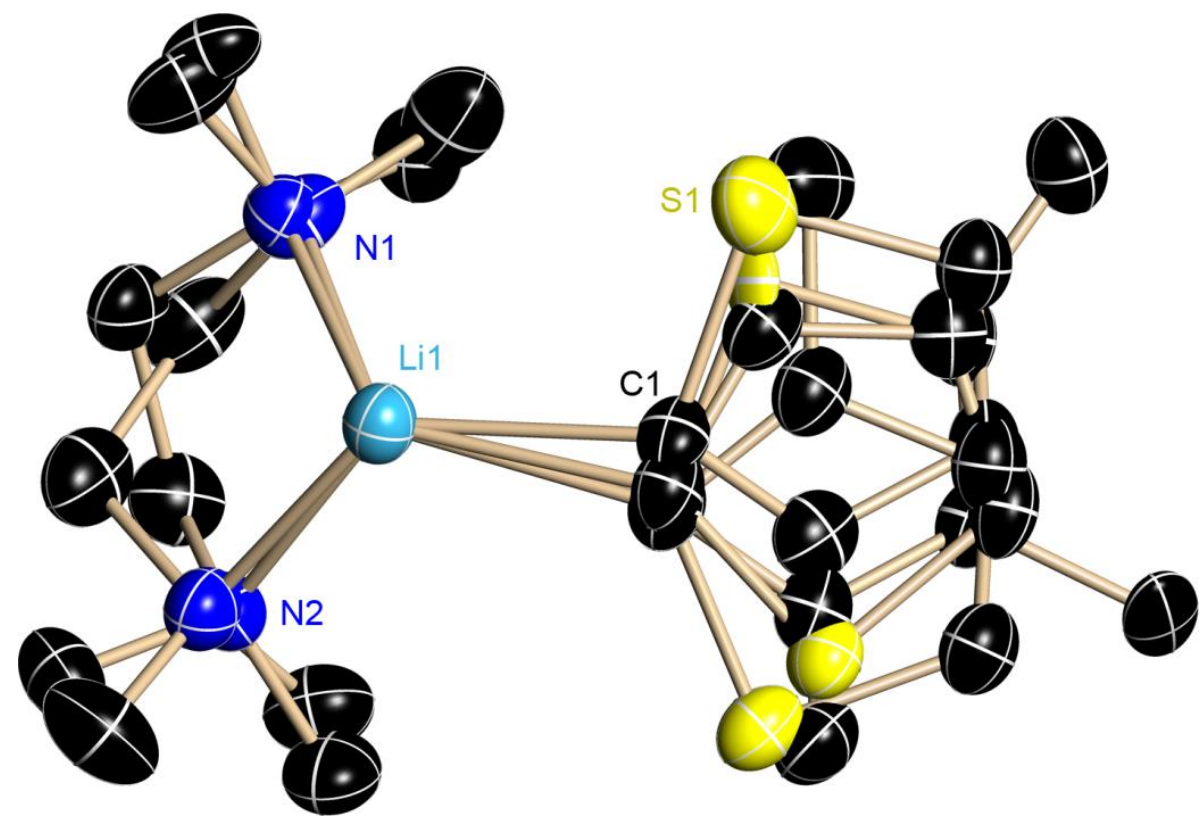

Scheme 6-4. Asymmetric unit of (8). The anisotropic displacement parameters are depicted at the $50 \%$ probability level. The hydrogen atoms are omitted for clarity.

Disorder described in the main text.

Table 6-5. Crystallographic data for $\mathbf{8}$.

\begin{tabular}{ll|ll}
\hline ID code & KES029 & $\mu$ mm $\left.^{-1}\right]$ & 0.213 \\
Empirical formula & $\mathrm{C}_{11} \mathrm{H}_{21} \mathrm{LN}_{2} \mathrm{~S}$ & $\mathrm{~F}(000)$ & 960 \\
Formula weight $[\mathrm{g} / \mathrm{mol}]$ & 220.30 & $\Theta$ range $\left[{ }^{\circ}\right]$ & 2.291 to 26.383 \\
Crystal system & Monoclinic & Reflections collected & 34584 \\
Space group & $C 2 / c$ & Indep. ref. / $R_{\text {int }}$ & $2733 / 0.0527$ \\
$a[\AA]$ & $22.381(3)$ & Completeness to $\Theta_{\max }$ & $99.7 \%$ \\
$b[\AA]$ & $8.525(2)$ & Max. / min. transmission & $0.9705 / 0.8567$ \\
$c[\AA]$ & $17.693(10)$ & Restraints / parameters & $1258 / 384$ \\
$\beta\left[{ }^{\circ}\right]$ & $127.40(2)$ & GoF & 1.133 \\
Volume $\left[\AA^{3}\right]$ & $2681.8(10)$ & $R 1 / w R 2(\mathrm{I}>2 \sigma(\mathrm{I}))$ & $0.0372 / 0.1020$ \\
$\mathrm{Z}$ & 8 & $R 1 / w R 2($ all data) & $0.0436 / 0.1053$ \\
Crystal size $[\mathrm{mm}]$ & $0.12 \times 0.06 \times 0.05$ & Diff. peak and hole $\left[\mathrm{e} \AA^{-3}\right]$ & 0.199 and -0.165 \\
$\rho_{\text {calc }}\left[\mathrm{Mg} / \mathrm{m}^{3}\right]$ & 1.091 & & \\
\hline
\end{tabular}




\subsection{5 $\quad\left[\left[\mathrm{Li}(\text { Diglyme })_{2}\right]\left[(\right.\right.$ Diglyme $\left.) \mathrm{Li}_{2}\left(\mathrm{C}_{4} \mathrm{H}_{3} \mathrm{~S}\right)_{3}\right](9)$}
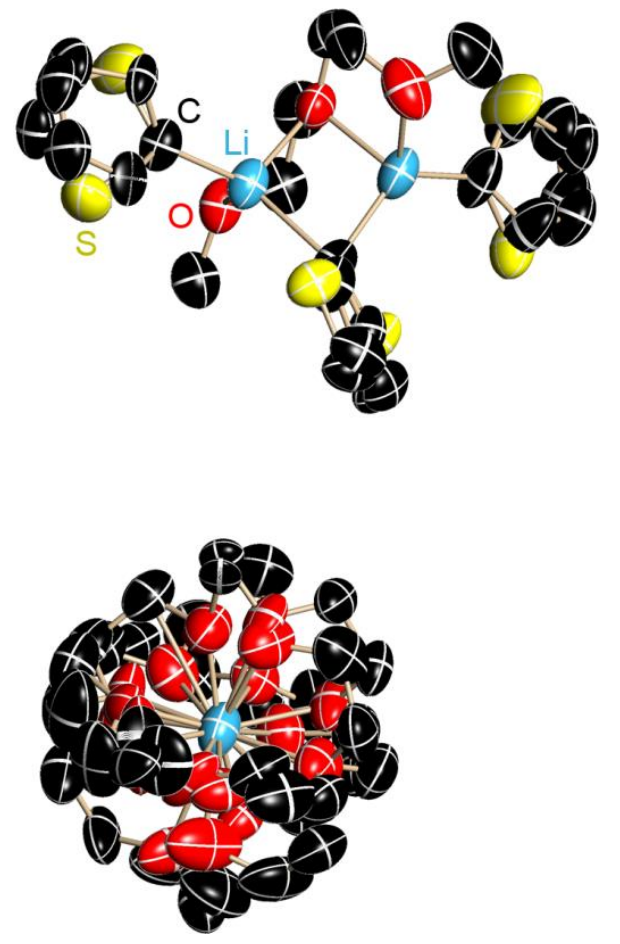

Scheme 6-5. Asymmetric unit of 9. The anisotropic displacement parameters are depicted at the $50 \%$ probability level. The hydrogen atoms are omitted for clarity.

Stable refinement of the positional disorder possible with distance and APD restraint.

Table 6-6. Crystallographic data for 9 of the Mo-I $\mu$ S experiment.

\begin{tabular}{ll|ll}
\hline ID code & ThiLi_diglyme & $\mu\left[\mathrm{mm}^{-1}\right]$ & 0.242 \\
Empirical formula & $\mathrm{C}_{30} \mathrm{H}_{51} \mathrm{Li}_{3} \mathrm{O}_{9} \mathrm{~S}_{3}$ & $\mathrm{~F}(000)$ & 2880 \\
Formula weight $[\mathrm{g} / \mathrm{mol}]$ & 672.71 & $\Theta$ range $\left.{ }^{\circ}\right]$ & 1.31 to 23.31 \\
Crystal system & Orthorhombic & Reflections collected & 172801 \\
Space group & $P b c a$ & Indep. ref. / $R_{\text {int }}$ & $5410 / 0.1626$ \\
$a[\AA]$ & $16.185(3)$ & Completeness to $\Theta_{\max }$ & $99.7 \%$ \\
$b[\AA]$ & $14.931(3)$ & Max. / min. transmission & $0.9705 / 0.8652$ \\
$c[\AA]$ & $31.134(6)$ & Restraints / parameters & $2249 / 856$ \\
Volume $\left[\AA^{3}\right]$ & $7511(3)$ & GoF & 1.420 \\
$Z$ & 8 & $R 1 / w R 2(\mathrm{I}>2 \sigma(\mathrm{I}))$ & $0.1055 / 0.3326$ \\
Crystal size $[\mathrm{mm}]$ & $0.3 \times 0.12 \times 0.11$ & $R 1 / w R 2($ all data $)$ & $0.1381 / 0.3630$ \\
$\rho_{\text {calc }}\left[\mathrm{Mg} / \mathrm{m}^{3}\right]$ & 1.190 & Diff. peak and hole $\left[\mathrm{e} \AA^{-3}\right]$ & 0.779 and -0.461 \\
\hline
\end{tabular}




\subsection{1 $\quad\left[(\text { PMDETA })_{2} \mathrm{Li}_{6} \mathrm{O}_{2}\left\{\left(\mathrm{C}_{4} \mathrm{H}_{2} \mathrm{O}\right)-5-\mathrm{Me}\right\}_{4}\right](10)$}

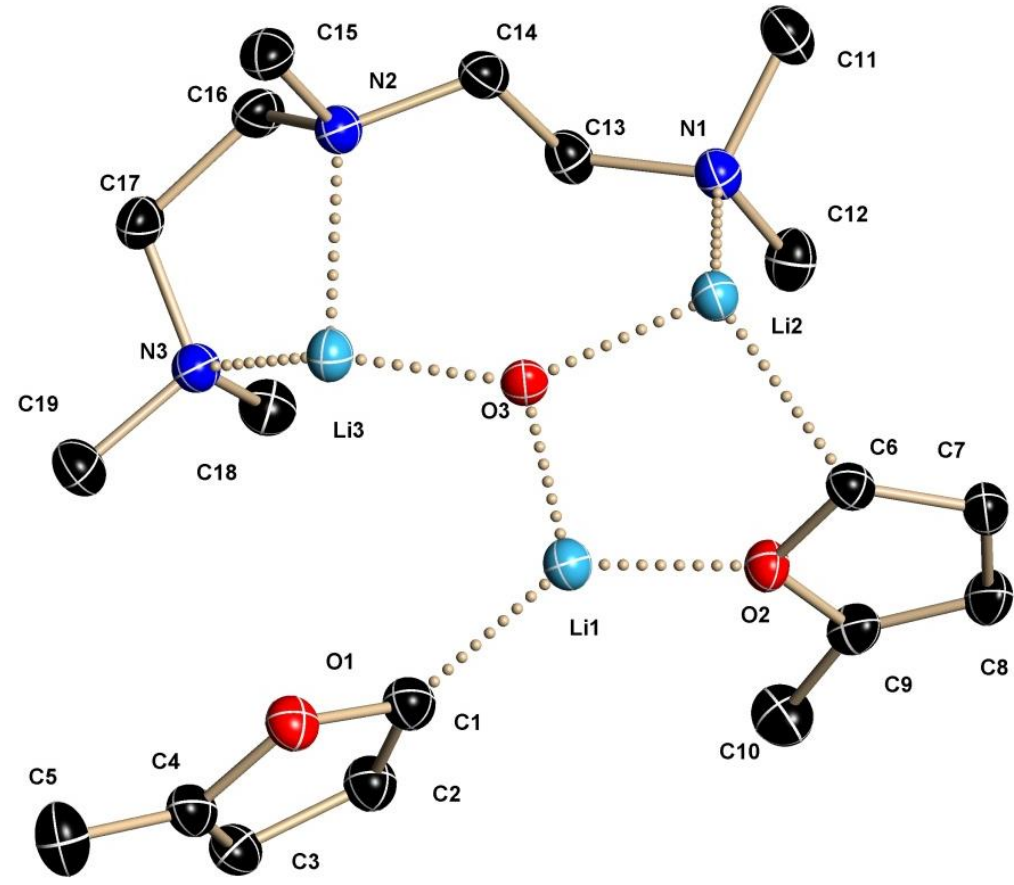

Scheme 6-6. Asymmetric unit of 10. The anisotropic displacement parameters are depicted at the $50 \%$ probability level. The hydrogen atoms are omitted for clarity.

The structure was measured during the bachelor thesis of E.K Schwarze.

Table 6-7. Crystallographic data for $\mathbf{1 0 .}$

\begin{tabular}{ll|ll}
\hline ID code & Kes005 & $\mu\left[\mathrm{mm}^{-1}\right]$ & 0.074 \\
Empirical formula & $\mathrm{C}_{38} \mathrm{H}_{66} \mathrm{Li}_{6} \mathrm{~N}_{6} \mathrm{O}_{6}$ & $\mathrm{~F}(000)$ & 1608 \\
Formula weight $[\mathrm{g} / \mathrm{mol}]$ & 744.61 & $\Theta$ range $\left[^{\circ}\right]$ & 2.03 to 25.36 \\
Crystal system & Orthorhombic & Reflections collected & 89524 \\
Space group & $P b c a$ & Independent reflections & $4008(0.0623)$ \\
$a[\AA]$ & $12.8621(6)$ & Completeness to $\Theta_{\max }$ & $99.9 \%$ \\
$b[\AA]$ & $16.9352(8)$ & Max. / min. transmission & $0.9892 / 0.8872$ \\
$c[\AA]$ & $20.0588(10)$ & Restraints / parameters & $0 / 260$ \\
Volume $\left[\AA^{3}\right]$ & $4368.6(4)$ & GoF & 1.033 \\
$\mathrm{Z}$ & 4 & $R 1 / w R 2(\mathrm{I}>2 \sigma(\mathrm{I}))$ & $0.0364 / 0.0944$ \\
Crystal size $[\mathrm{mm}]$ & $0.22 \times 0.16 \times 0.11$ & $R 1 / w R 2($ all data $)$ & $0.0450 / 0.1006$ \\
$\rho_{\text {calc }}\left[\mathrm{Mg} / \mathrm{m}^{3}\right]$ & 1.132 & Diff. peak and hole $\left[\mathrm{e} \AA^{-3}\right]$ & 0.236 and -0.208 \\
\hline
\end{tabular}




\subsection{2 $\left[\left\{\mathrm{Li}(\mathrm{DME})_{2}\right\}_{2} \mathrm{Li}_{12}\left\{\left[\mathrm{C}_{4} \mathrm{H}_{3} \mathrm{O}\right]_{8}\left[\mathrm{OCH}_{3}\right]_{6}\right\}\right](11)$}
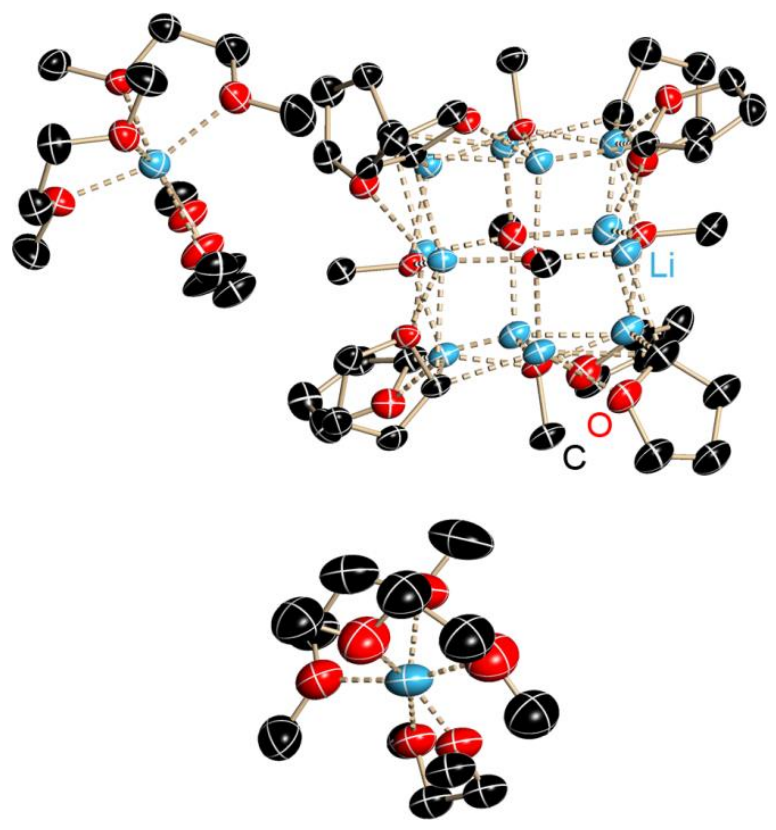

Scheme 6-7. Asymmetric unit of 11. The anisotropic displacement parameters are depicted at the $50 \%$ probability level. The hydrogen atoms are omitted for clarity.

The structure was measured during the bachelor thesis of E.K Schwarze. Positional disorder of the diglyme molecule in the SSIP cation and three 5-methyl-2-furyllithium moieties were refined applying ADP and distance restraints.

Table 6-8. Crystallographic data for 11.

\begin{tabular}{ll|ll}
\hline ID code & & $\rho_{\text {calc }}\left[\mathrm{Mg} / \mathrm{m}^{3}\right]$ & 1.168 \\
Empirical formula & $\mathrm{C}_{62} \mathrm{H}_{102} \mathrm{Li}_{14} \mathrm{O}_{26}$ & $\mu\left[\mathrm{mm}^{-1}\right]$ & 0.086 \\
Formula weight $[\mathrm{g} / \mathrm{mol}]$ & 1360.59 & $\mathrm{~F}(000)$ & 1448 \\
Crystal system & Triclinic & $\Theta$ range $\left[{ }^{\circ}\right]$ & 1.644 to 23.964 \\
Space group & $P \overline{1}$ & Reflections collected & 66658 \\
$a[\AA]$ & $13.955(2)$ & Independent reflections & $12060(0.1676)$ \\
$b[\AA]$ & $17.078(2)$ & Completeness to $\Theta_{\text {max }}$ & $86.2 \%$ \\
$c[\AA]$ & $18.316(3)$ & Max. / min. transmission & $0.9705 / 0.9030$ \\
$\alpha\left[^{\circ}\right]$ & $78.48(2)$ & Restraints / parameters & $3975 / 1095$ \\
$\beta\left[^{\circ}\right]$ & $73.54(2)$ & GoF & 1.046 \\
$\gamma\left[^{\circ}\right]$ & $68.32(2)$ & $R 1 / w R 2(\mathrm{I}>2 \sigma(\mathrm{I}))$ & $0.0986 / 0.2632$ \\
Volume $\left[\AA^{3}\right]$ & $3867.9(12)$ & $R 1 / w R 2($ all data) & $0.2108 / 0.3379$ \\
$\mathrm{Z}$ & 2 & Diff. peak and hole $\left[\mathrm{e} \AA^{-3}\right]$ & 0.684 and -0.428 \\
Crystal size $[\mathrm{mm}]$ & $0.2 \times 0.1 \times 0.1$ & & \\
\hline
\end{tabular}




\subsection{3 $\left[\left[\left(\mathrm{SC}_{4} \mathrm{H}_{3}\right)_{2}\left(\mathrm{NEt}_{2}\right) \mathrm{PNiCl}_{2}\right](13)\right.$}

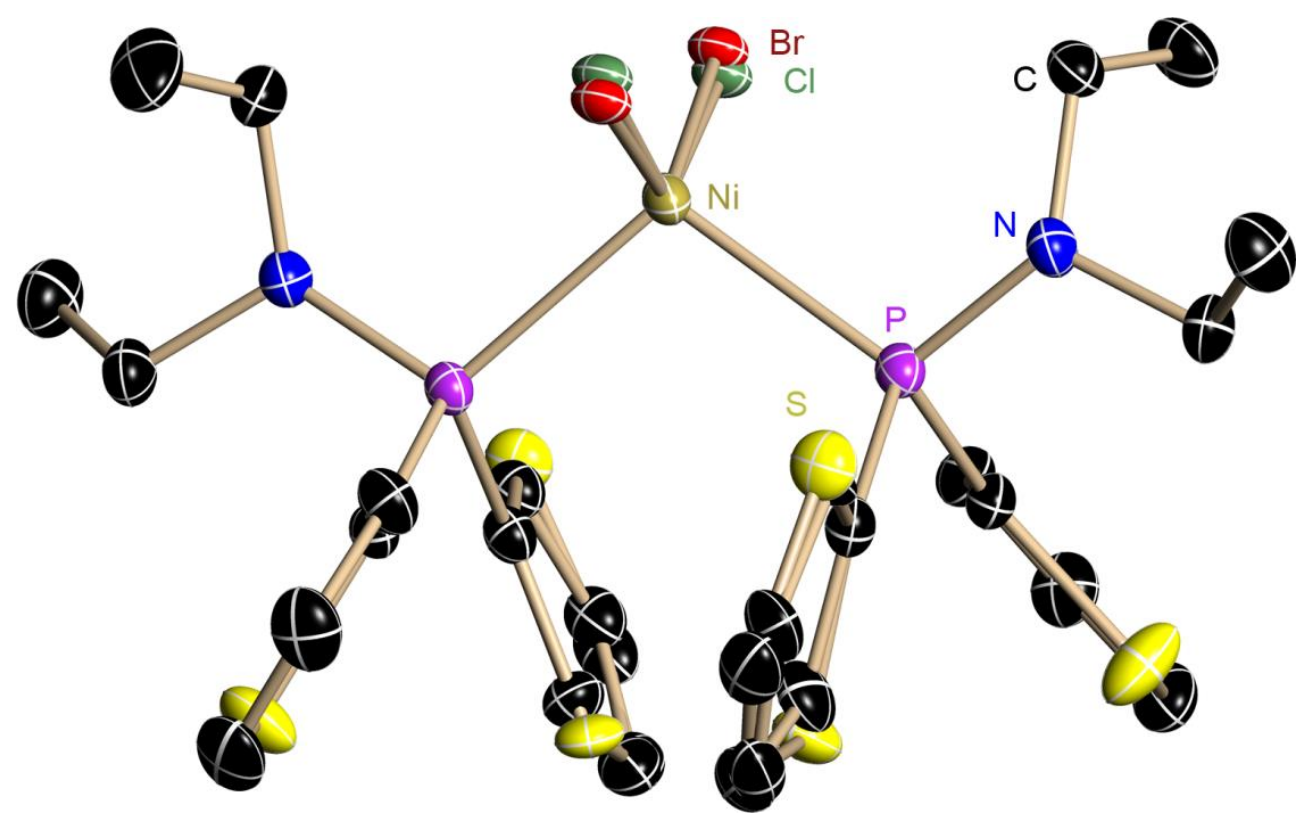

Scheme 6-8. Asymmetric unit of (13). The anisotropic displacement parameters are depicted at the $50 \%$ probability level. The hydrogen atoms and solvent toluene molecule are omitted for clarity.

13 crystallizes as a non-merohedral twin, the BASF refined to 0.46 .

Thiophene disorder SOFs refine to 0.69 and 0.74 .

Table 6-9. Crystallographic data for $\mathbf{1 3 .}$

\begin{tabular}{ll|ll}
\hline Id code & $\mathrm{Mgx} 003$ & $\rho_{\text {calc }}\left[\mathrm{Mg} / \mathrm{m}^{3}\right]$ & 1.444 \\
Empirical formula & $\mathrm{C}_{31} \mathrm{H}_{40} \mathrm{Cl}_{1.48} \mathrm{Br}_{0.52} \mathrm{~N}$ & $\mu\left[\mathrm{mm}^{-1}\right]$ & 1.571 \\
& ${ }_{2} \mathrm{~S}_{4} \mathrm{P}_{2} \mathrm{Ni}$ & $\mathrm{F}(000)$ & 811 \\
Formula weight $[\mathrm{g} / \mathrm{mol}]$ & 783.62 & $\Theta$ range $\left[^{\circ}\right]$ & 1.434 to 26.755 \\
Crystal system & Triclinic & Reflections collected & 10860 \\
Space group & $P \overline{1}$ & Independent reflections & $7607(0.0452)$ \\
$a[\AA]$ & $11.175(2)$ & Completeness to $\Theta_{\max }$ & $99.9 \%$ \\
$b[\AA]$ & $11.357(2)$ & Max. / min. transmission & $0.9802 / 0.8521$ \\
$c[\AA]$ & $14.423(3)$ & Restraints / parameters & $454 / 461$ \\
$\alpha\left[^{\circ}\right]$ & $86.64(2)$ & GoF & 1.027 \\
$\beta\left[^{\circ}\right]$ & $80.43(2)$ & $R 1 / w R 2(\mathrm{I}>2 \sigma(\mathrm{I}))$ & $0.0357 / 0.0685$ \\
$\gamma\left[^{\circ}\right]$ & $89.89(3)$ & $R 1 / w R 2($ all data) & $0.0513 / 0.0741$ \\
Volume $\left[\AA^{3}\right]$ & $1802.2(6)$ & Diff. peak and hole $\left[\mathrm{e} \AA^{-3}\right]$ & 0.443 and -0.472 \\
$\mathrm{Z}$ & 2 & & \\
Crystal size $[\mathrm{mm}]$ & $0.12 \times 0.1 \times 0.08$ & & \\
\hline
\end{tabular}




\subsection{4 $\quad\left[\left(\mathrm{SC}_{4} \mathrm{H}_{3}\right)_{2}\left(\mathrm{NEt}_{2}\right) \mathrm{PCuCl}(\mathrm{MeCN})\right]_{2}(14)$}

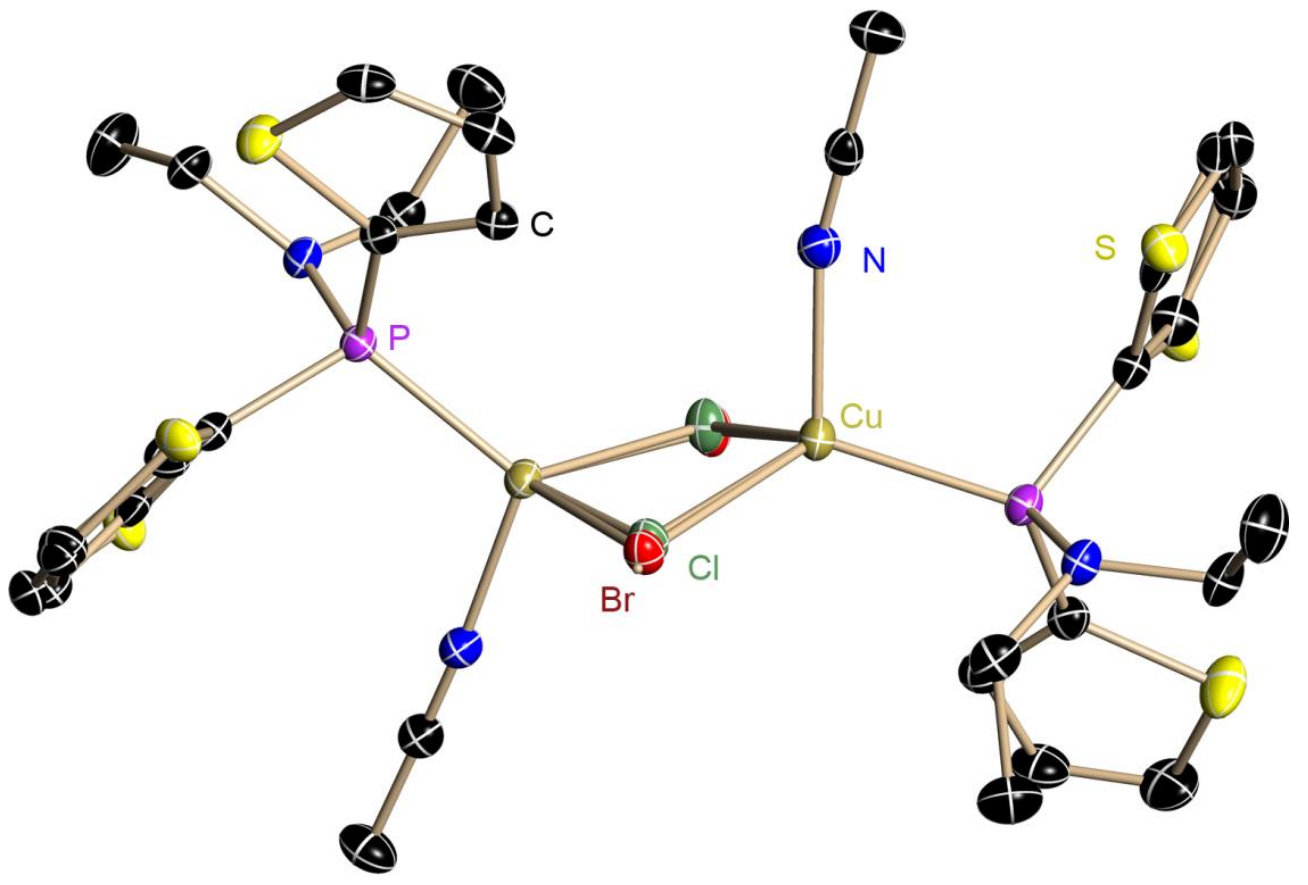

Scheme 6-9. Asymmetric unit of (14). The anisotropic displacement parameters are depicted at the $50 \%$ probability level. The hydrogen atoms are omitted for clarity.

Thiophene disorder SOFs refine to 0.68 and 0.92 ; two moieties show no disorder.

Table 6-10. Crystallographic data for 14.

\begin{tabular}{|c|c|c|c|}
\hline \multicolumn{2}{|l|}{ CCDC no. } & $\rho_{\text {calc }}\left[\mathrm{Mg} / \mathrm{m}^{3}\right]$ & 1.544 \\
\hline Empirical formula & $\begin{array}{l}\mathrm{C}_{28} \mathrm{H}_{38} \mathrm{Cl}_{1.90} \mathrm{Br}_{0.10} \mathrm{~N} \\
{ }_{4} \mathrm{~S}_{4} \mathrm{P}_{2} \mathrm{Cu}\end{array}$ & $\mu\left[\mathrm{mm}^{-1}\right]$ & 1.805 \\
\hline Formula weight $[\mathrm{g} / \mathrm{mol}]$ & 823.02 & $\mathrm{~F}(000)$ & 843 \\
\hline Crystal system & Triclinic & $\Theta$ range $\left[{ }^{\circ}\right]$ & 1.385 to 26.768 \\
\hline Space group & $P \overline{1}$ & Reflections collected & 43755 \\
\hline$a[\AA]$ & $9.040(2)$ & Independent reflections & $7548(0.0551)$ \\
\hline$b[\AA]$ & $13.599(2)$ & Completeness to $\Theta_{\max }$ & $100.0 \%$ \\
\hline$c[\AA]$ & $15.166(3)$ & Max. / min. transmission & 0.9509 and 0.8549 \\
\hline$\alpha\left[^{\circ}\right]$ & $101.22(2)$ & Restraints / parameters & $442 / 467$ \\
\hline$\beta\left[^{\circ}\right]$ & $96.09(2)$ & GoF & 1.060 \\
\hline$\gamma\left[{ }^{\circ}\right]$ & $101.64(3)$ & $R 1 / w R 2(\mathrm{I}>2 \sigma(\mathrm{I}))$ & $0.0316 / 0.0641$ \\
\hline Volume $\left[\AA^{3}\right]$ & $177.6(6)$ & $R 1 / w R 2$ (all data) & $0.0446 / 0.0695$ \\
\hline $\mathrm{Z}$ & 2 & Diff. peak and hole $\left[\mathrm{e} \AA^{-3}\right]$ & 0.395 and -0.424 \\
\hline Crystal size [mm] & $\begin{array}{l}0.125 \times 0.08 \times 0.0 \\
3\end{array}$ & & \\
\hline
\end{tabular}




\subsection{5 $\left[\left\{\left(\mathrm{SC}_{4} \mathrm{H}_{3}\right)_{2}\left(\mathrm{NEt}_{2}\right) \mathrm{P}\right\}_{2} \mathrm{PdCl}_{2}\right](15)$}
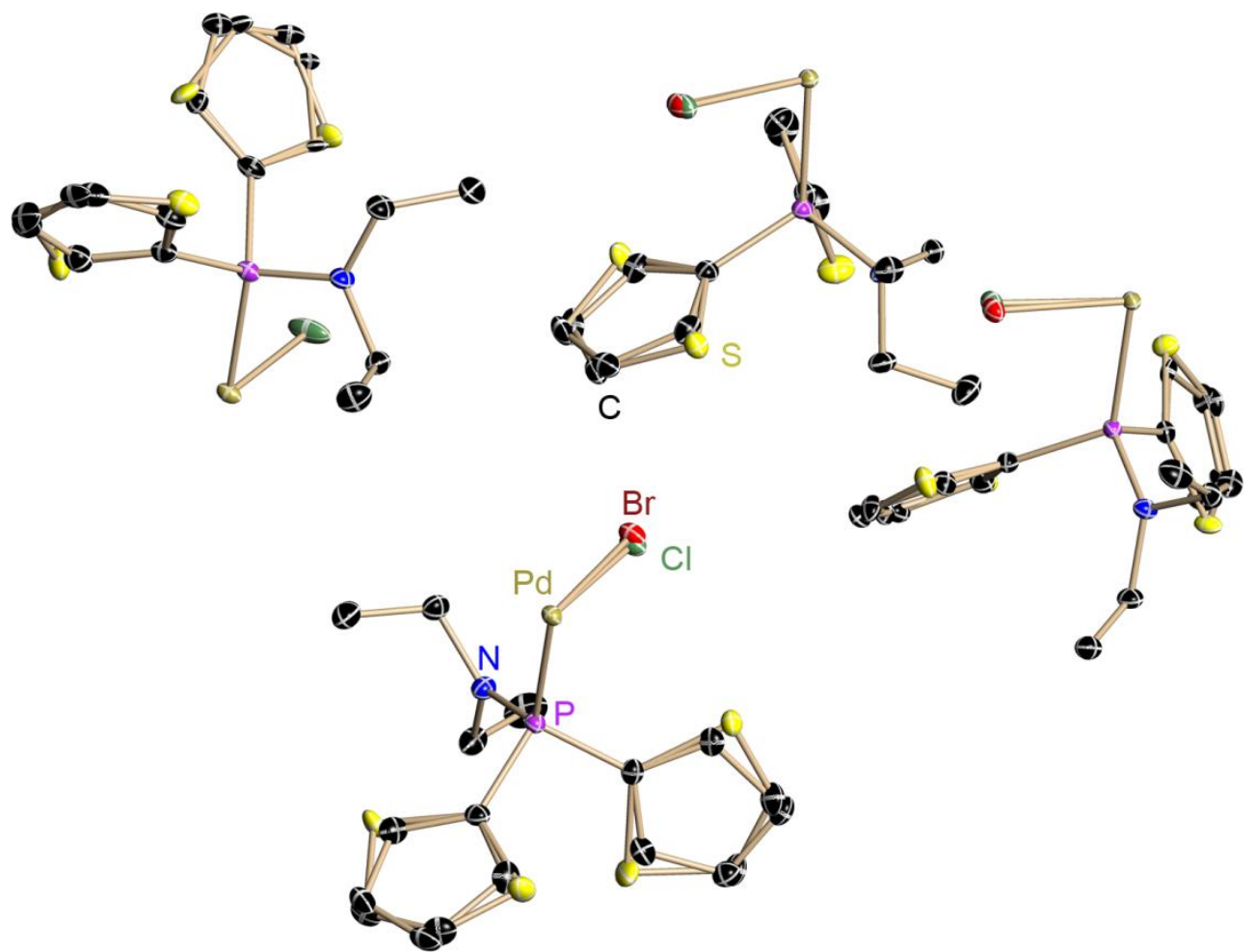

Scheme 6-10. Asymmetric unit of (15). The anisotropic displacement parameters are depicted at the $50 \%$ probability level. The hydrogen atoms are omitted for clarity.

Crystallize as a non-merohedral twin BASF: 0.157

Table 6-11. Crystallographic data for $\mathbf{1 5 .}$

\begin{tabular}{ll|ll}
\hline CCDC no. & & $\rho_{\text {calc }}\left[\mathrm{Mg} / \mathrm{m}^{3}\right]$ & 1.656 \\
Empirical formula & $\mathrm{C}_{24} \mathrm{H}_{32} \mathrm{Cl}_{1.78} \mathrm{Br}_{0.22} \mathrm{~N}$ & $\mu\left[\mathrm{mm}^{-1}\right]$ & 1.519 \\
& ${ }_{2} \mathrm{~S}_{4} \mathrm{P}_{2} \mathrm{Pd}$ & & \\
Formula weight $[\mathrm{g} / \mathrm{mol}]$ & 725.79 & $\mathrm{~F}(000)$ & 1472 \\
Crystal system & Triclinic & $\Theta$ range $\left[{ }^{\circ}\right]$ & 1.298 to 27.572 \\
Space group & $P \overline{1}$ & Reflections collected & 15604 \\
$a[\AA]$ & $11.796(2)$ & Independent reflections & $5232(0.070)$ \\
$b[\AA]$ & $15.737(3)$ & Completeness to $\Theta_{\max }$ & $100.0 \%$ \\
$c[\AA]$ & $17.501(2)$ & Max. / min. transmission & $0.7455 / 0.65511$ \\
$\alpha\left[^{\circ}\right]$ & $63.96(2)$ & Restraints / parameters & $2340 / 921$ \\
$\beta\left[^{\circ}\right]$ & $85.82(2)$ & GoF & 1.016 \\
$\gamma\left[^{\circ}\right]$ & $87.83(3)$ & $R 1 / w R 2(\mathrm{I}>2 \sigma(\mathrm{I}))$ & $0.0274 / 0.0543$ \\
$V^{\circ}$ olume $\left[\AA^{3}\right]$ & $2911.2(8)$ & $R 1 / w R 2($ all data) & $0.0372 / 0.0580$ \\
$\mathrm{Z}$ & 4 & Diff. peak and hole $\left[\mathrm{e} \AA^{-3}\right]$ & 0.506 and -0.368 \\
Crystal size $[\mathrm{mm}]$ & $0.20 \times 0.12 \times 0.12$ & & \\
\hline
\end{tabular}




\subsection{6 $\left[\left[\left(\mathrm{SC}_{4} \mathrm{H}_{3}\right)_{2}\left(\mathrm{NEt}_{2}\right) \mathrm{PCl}\right]_{2}\right)(16)$}

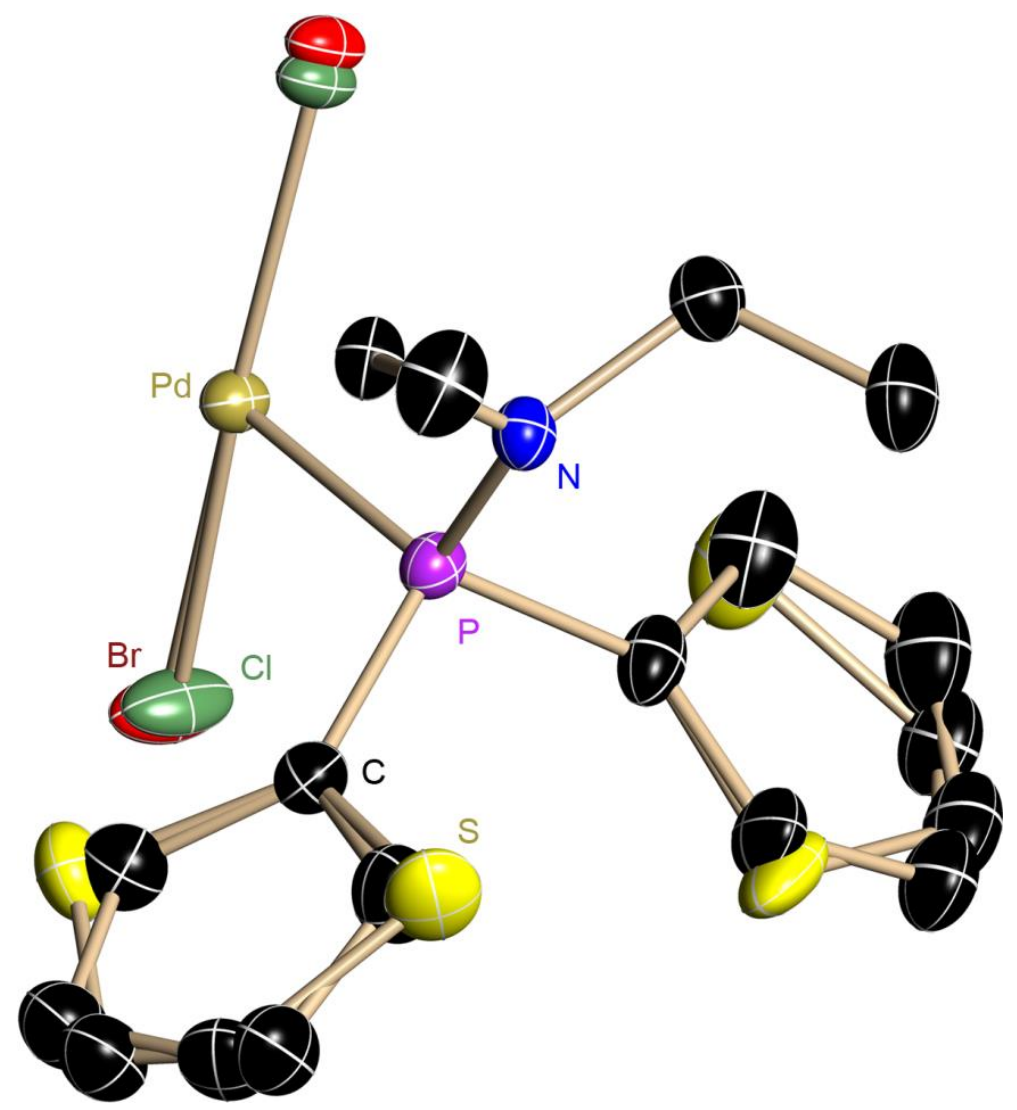

Scheme 6-11. Asymmetric unit of (16). The anisotropic displacement parameters are depicted at the $50 \%$ probability level. The hydrogen atoms are omitted for clarity.

Table 6-12. Crystallographic data for $\mathbf{1 6 .}$

\begin{tabular}{ll|ll}
\hline CCDC no. & & $\mu\left[\mathrm{mm}^{-1}\right]$ & 1.548 \\
Empirical formula & $\begin{array}{l}\mathrm{C}_{38} \mathrm{H}_{48} \mathrm{Cl}_{3.75} \mathrm{Br}_{0.25} \mathrm{~N} \\
{ }_{2} \mathrm{~S}_{4} \mathrm{P}_{2} \mathrm{Pd}_{2}\end{array}$ & $\mathrm{~F}(000)$ & 1097 \\
Formula weight $[\mathrm{g} / \mathrm{mol}]$ & 1088.85 & $\Theta$ range $\left[^{\circ}\right]$ & 1.926 to 25.242 \\
Crystal system & Monoclinic & Reflections collected & 27728 \\
Space group & $P 2{ }_{1} / n$ & Independent reflections & $4932(0.0463)$ \\
$a[\AA]$ & $9.901(2)$ & Completeness to $\Theta_{\text {max }}$ & $100.0 \%$ \\
$b[\AA]$ & $15.915(3)$ & Max. / min. transmission & $0.9703 / 0.8617$ \\
$c[\AA]$ & $14.479(2)$ & Restraints / parameters & $425 / 320$ \\
$\beta\left[{ }^{\circ}\right]$ & $102.35(2)$ & GoF & 1.055 \\
Volume $\left[\AA^{3}\right]$ & $2228.7(7)$ & $R 1 / w R 2(\mathrm{I}>2 \sigma(\mathrm{I}))$ & $0.0293 / 0.0569$ \\
$\mathrm{Z}$ & 2 & $R 1 / w R 2($ all data) & $0.0419 / 0.0622$ \\
$\mathrm{Crystal} \mathrm{size}[\mathrm{mm}]$ & $0.08 \times 0.07 \times 0.04$ & Diff. peak and hole $\left[\mathrm{e} \AA^{-3}\right]$ & 0.645 and -0.437 \\
$\rho_{\text {calc }}\left[\mathrm{Mg} / \mathrm{m}^{3}\right]$ & 1.623 & & \\
\hline
\end{tabular}




\subsection{7 $\quad\left[\left(\mathrm{SC}_{4} \mathrm{H}_{3}\right)_{2}\left(\mathrm{NEt}_{2}\right) \operatorname{PIrCl}(\mathrm{COD})\right](17)$}

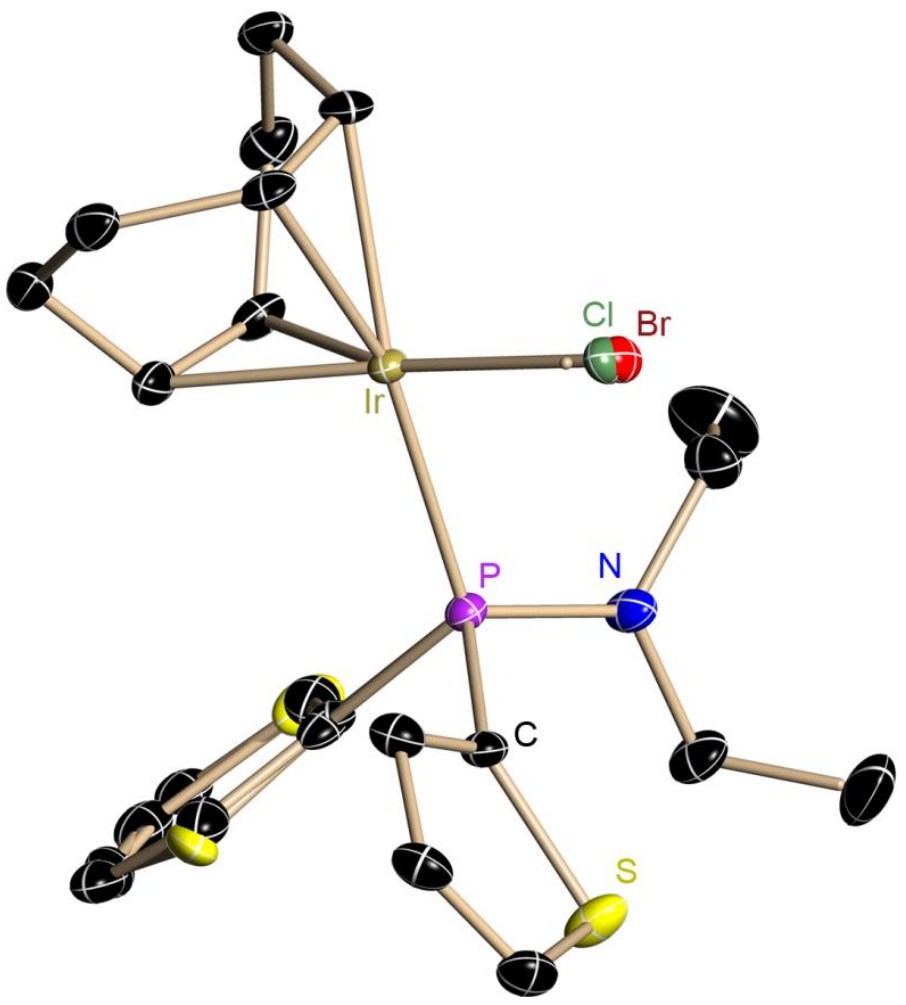

Scheme 6-12. Asymmetric unit of (17). The anisotropic displacement parameters are depicted at the $50 \%$ probability level. The hydrogen atoms are omitted for clarity.

Table 6-13. Crystallographic data for 17.

\begin{tabular}{|c|c|c|c|}
\hline & $\rho_{\text {calc }}\left[\mathrm{Mg} / \mathrm{m}^{3}\right]$ & 1.799 \\
\hline $\begin{array}{l}\text { CCDC no. } \\
\text { Empirical formula }\end{array}$ & $\begin{array}{l}\mathrm{C}_{23.50} \mathrm{H}_{32} \mathrm{Br}_{0.24} \mathrm{Cl}_{0.7} \\
{ }_{6} \mathrm{NIrNPS}_{2}\end{array}$ & $\mu\left[\mathrm{mm}^{-1}\right]$ & 6.190 \\
\hline Formula weight $[\mathrm{g} / \mathrm{mol}]$ & 662.01 & $\mathrm{~F}(000)$ & 651 \\
\hline Crystal system & Triclinic & $\Theta$ range $\left[{ }^{\circ}\right]$ & 1.287 to 27.484 \\
\hline Space group & $P \overline{1}$ & Reflections collected & 23891 \\
\hline$a[\AA]$ & $8.179(2)$ & Independent reflections & $5604(0.0318)$ \\
\hline$b[\AA]$ & $9.873(2)$ & Completeness to $\Theta_{\max }$ & $100.0 \%$ \\
\hline$c[\AA]$ & $16.129(4)$ & Max. / min. transmission & $0.7458 / 0.6891$ \\
\hline$\alpha\left[^{\circ}\right]$ & $78.81(2)$ & Restraints / parameters & $138 / 214$ \\
\hline$\beta\left[^{\circ}\right]$ & $88.14(3)$ & $\mathrm{GoF}$ & 1.034 \\
\hline$\gamma\left[{ }^{\circ}\right]$ & $73.07(2)$ & $R 1 / w R 2(\mathrm{I}>2 \sigma(\mathrm{I}))$ & $0.0145 / 0.0337$ \\
\hline Volume $\left[\AA^{3}\right]$ & $1221.9(4)$ & $R 1 / w R 2$ (all data) & $0.0153 / 0.0340$ \\
\hline $\mathrm{Z}$ & 2 & Diff. peak and hole $\left[\mathrm{e}^{-3}\right]$ & 0.718 and -0.550 \\
\hline Crystal size $[\mathrm{mm}]$ & $0.11 \times 0.1 \times 0.1$ & & \\
\hline
\end{tabular}




\subsection{8 $\left[\left(\mathrm{SC}_{4} \mathrm{H}_{3}\right)_{2}\left(\mathrm{NEt}_{2}\right) \mathrm{PAuCl}\right](18)$}

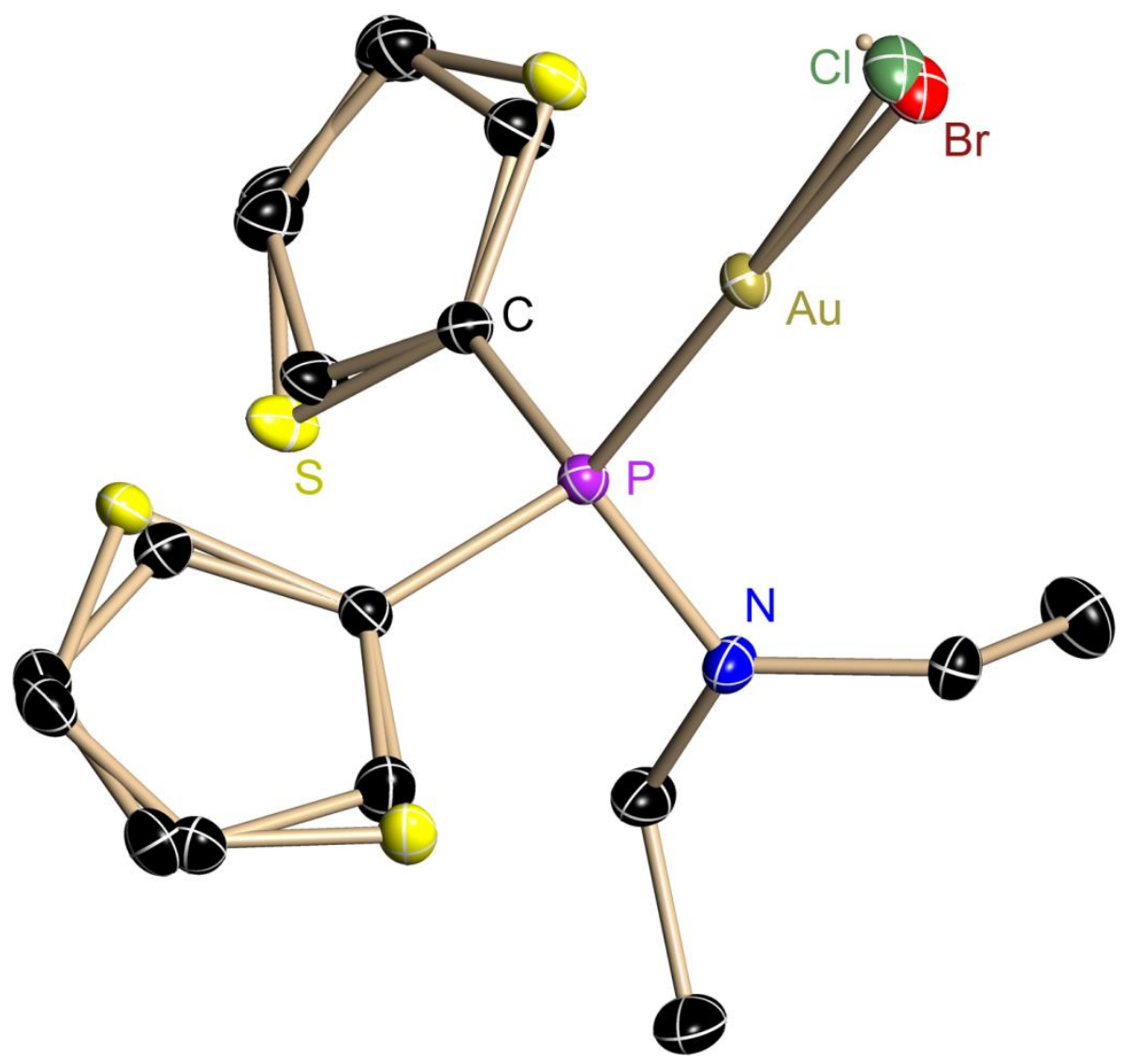

Scheme 6-13. Asymmetric unit of (18). The anisotropic displacement parameters are depicted at the $50 \%$ probability level. The hydrogen atoms are omitted for clarity.

Table 6-14. Crystallographic data for $\mathbf{1 8 .}$

\begin{tabular}{ll|ll}
\hline CCDC no. & & $\mu\left[\mathrm{mm}^{-1}\right]$ & 10.178 \\
Empirical formula & $\mathrm{C}_{12} \mathrm{H}_{16} \mathrm{Cl}_{0.95} \mathrm{Br}_{0.05} \mathrm{NPS}_{2} \mathrm{~A}$ & $\mathrm{~F}(000)$ & 955 \\
& $\mathrm{u}$ & & \\
Formula weight $[\mathrm{g} / \mathrm{mol}]$ & 503.78 & $\Theta$ range $\left[^{\circ}\right]$ & 2.20 to 37.089 \\
Crystal system & Monoclinic & Reflections collected & 51624 \\
Space group & $P 2_{1} / n$ & Independent reflections & $7865(0.0240)$ \\
$a[\AA]$ & $7.896(2)$ & Completeness to $\Theta_{\max }$ & $99.9 \%$ \\
$b[\AA]$ & $10.748(2)$ & Max. / min. transmission & $0.667 / 0.503$ \\
$c[\AA]$ & $18.415(3)$ & Restraints / parameters & $400 / 243$ \\
$\beta\left[{ }^{\circ}\right]$ & $99.32(2)$ & GoF & 1.027 \\
Volume $\left[\AA^{3}\right]$ & $1542.2(5)$ & $R 1 / w R 2(\mathrm{I}>2 \sigma(\mathrm{I}))$ & $0.0156 / 0.0286$ \\
$\mathrm{Z}$ & 4 & $R 1 / w R 2$ (all data) & $0.0239 / 0.0304$ \\
Crystal size $[\mathrm{mm}]$ & $0.10 \times 0.05 \times 0.05$ & Diff. peak and hole $\left[\mathrm{e} \AA^{-3}\right]$ & 0.908 and -1.067 \\
$\rho_{\text {calc }}\left[\mathrm{Mg} / \mathrm{m}^{3}\right]$ & 2.170 & & \\
\hline
\end{tabular}




\subsection{1 $\quad$ Thi $_{2} \mathrm{PCl}(20)$}
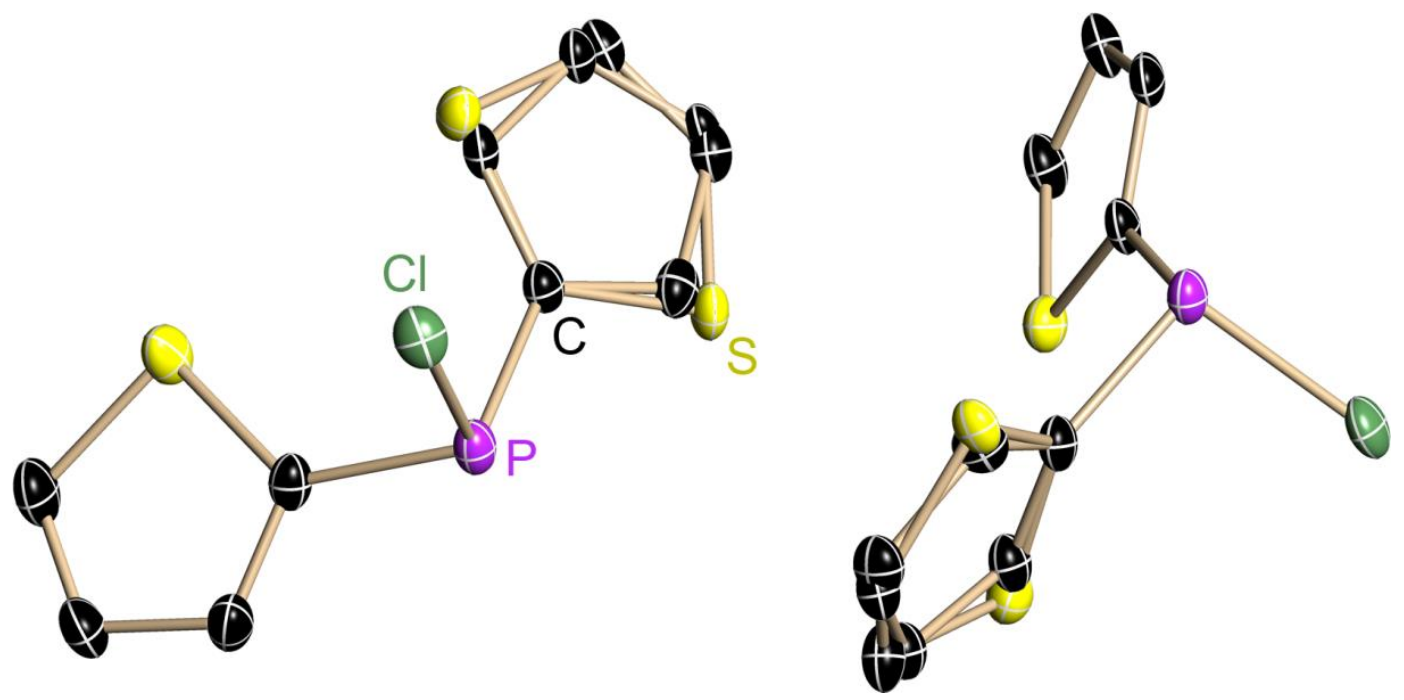

Scheme 6-14. Asymmetric unit of (20). The anisotropic displacement parameters are depicted at the $50 \%$ probability level. The hydrogen atoms are omitted for clarity.

Table 6-15. Crystallographic data for $\mathbf{2 0}$.

\begin{tabular}{ll|ll}
\hline ID code & MGW009 & $\mu\left[\mathrm{mm}^{-1}\right]$ & 0.930 \\
Empirical formula & $\mathrm{C} 8 \mathrm{H} 6 \mathrm{~S} 3 \mathrm{PCl}$ & $\mathrm{F}(000)$ & 3776 \\
Formula weight $[\mathrm{g} / \mathrm{mol}]$ & 232.67 & $\Theta$ range $\left[^{\circ}\right]$ & 1.392 to 26.825 \\
Crystal system & Orthorhombic & Reflections collected & 30904 \\
Space group & $F d d 2$ & Indep. ref. / $R_{\text {int }}$ & $4140(0.0648)$ \\
$a[\AA]$ & $23.319(3)$ & Completeness to $\Theta_{\max }$ & 99.9 \\
$b[\AA]$ & $58.509(6)$ & Max. / min. transmission & $0.9705 / 0.8157$ \\
$c[\AA]$ & $5.666(2)$ & Restraints / parameters & $541 / 291$ \\
Volume $\left[\AA^{3}\right]$ & $7731(3)$ & GoF & 1.084 \\
$Z$ & 32 & $R 1 / w R 2(\mathrm{I}>2 \sigma(\mathrm{I}))$ & $0.0304 / 0.0610$ \\
Crystal size $[\mathrm{mm}]$ & $0.17 \times 0.10 \mathrm{x} 0.02$ & $R 1 / w R 2($ all data $)$ & $0.0351 / 0.0624$ \\
$\rho_{\text {calc }}\left[\mathrm{Mg} / \mathrm{m}^{3}\right]$ & 1.599 & Diff. peak and hole $\left[\mathrm{e} \AA^{-3}\right]$ & $0.265 /-0.258$ \\
\hline
\end{tabular}




\subsection{1 $\quad \mathrm{Thi}_{2} \mathrm{P}(\mathrm{O}) \mathrm{OH}(22)$}

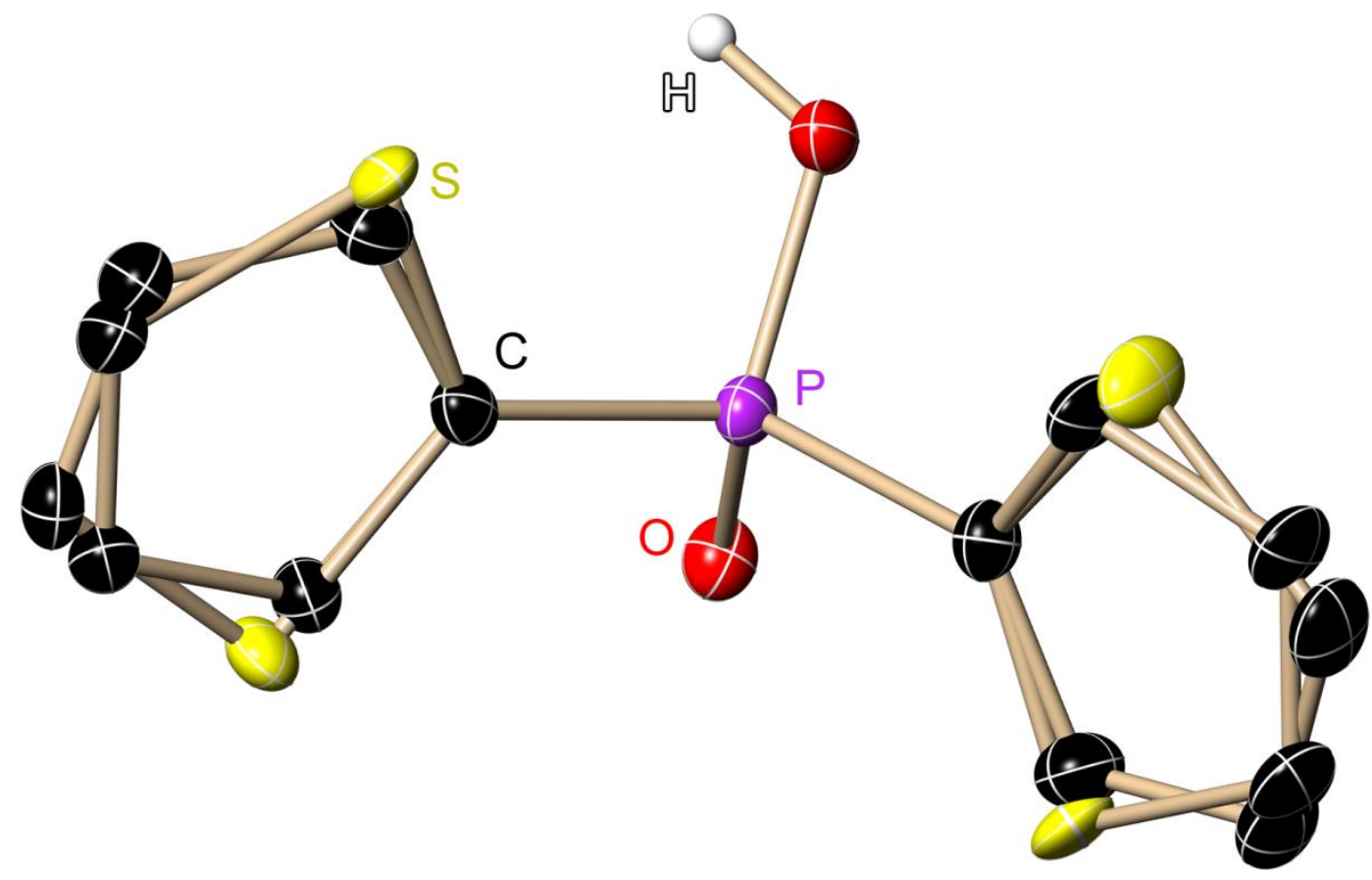

Scheme 6-15. Asymmetric unit of (22). The anisotropic displacement parameters are depicted at the $50 \%$ probability level. The hydrogen atoms are omitted for clarity.

Hydrogen position found from density map and refinded freely.

Table 6-16. Crystallographic data for 22.

\begin{tabular}{ll|ll}
\hline CCDC no. & & $\mu\left[\mathrm{mm}^{-1}\right]$ & 0.677 \\
Empirical formula & $\mathrm{C}_{8} \mathrm{H}_{7} \mathrm{O}_{2} \mathrm{PS}_{2}$ & $\mathrm{~F}(000)$ & 472 \\
Formula weight $[\mathrm{g} / \mathrm{mol}]$ & 230.23 & $\Theta$ range $\left[{ }^{\circ}\right]$ & 1.883 to 26.752 \\
Crystal system & Monoclinic & Reflections collected & 14086 \\
Space group & $P 2_{1} / n$ & Indep. ref. / $R_{\text {int }}$ & $2044(0.0249)$ \\
$a[\AA]$ & $12.307(2)$ & Completeness to $\Theta_{\max }$ & $99.9 \%$ \\
$b[\AA]$ & $6.290(2)$ & Max. / min. transmission & $0.9705 / 0.9190$ \\
$c[\AA]$ & $13.650(3)$ & Restraints / parameters & $340 / 196$ \\
$\beta\left[^{\circ}\right]$ & $113.90(2)$ & GoF & 1.060 \\
Volume $\left[\AA^{3}\right]$ & $966.1(4)$ & $R 1 / w R 2(\mathrm{I}>2 \sigma(\mathrm{I}))$ & $0.0236 / 0.0610$ \\
$\mathrm{Z}$ & 4 & $R 1 / w R 2($ all data) & $0.0278 / 0.0636$ \\
Crystal size $[\mathrm{mm}]$ & $0.2 \times 0.05 \times 0.05$ & Diff. peak and hole $\left[\mathrm{e} \AA^{-3}\right]$ & 0.364 and -0.260 \\
$\rho_{\text {calc }}\left[\mathrm{Mg} / \mathrm{m}^{3}\right]$ & 1.583 & & \\
\hline
\end{tabular}




\subsection{2 $\left[\left\{(\text { FurPh })_{2} \mathrm{P}_{2}\right\} \mathrm{Au}_{2} \mathrm{Cl}_{2}(\mathrm{FurPhPH})\right](23)$}

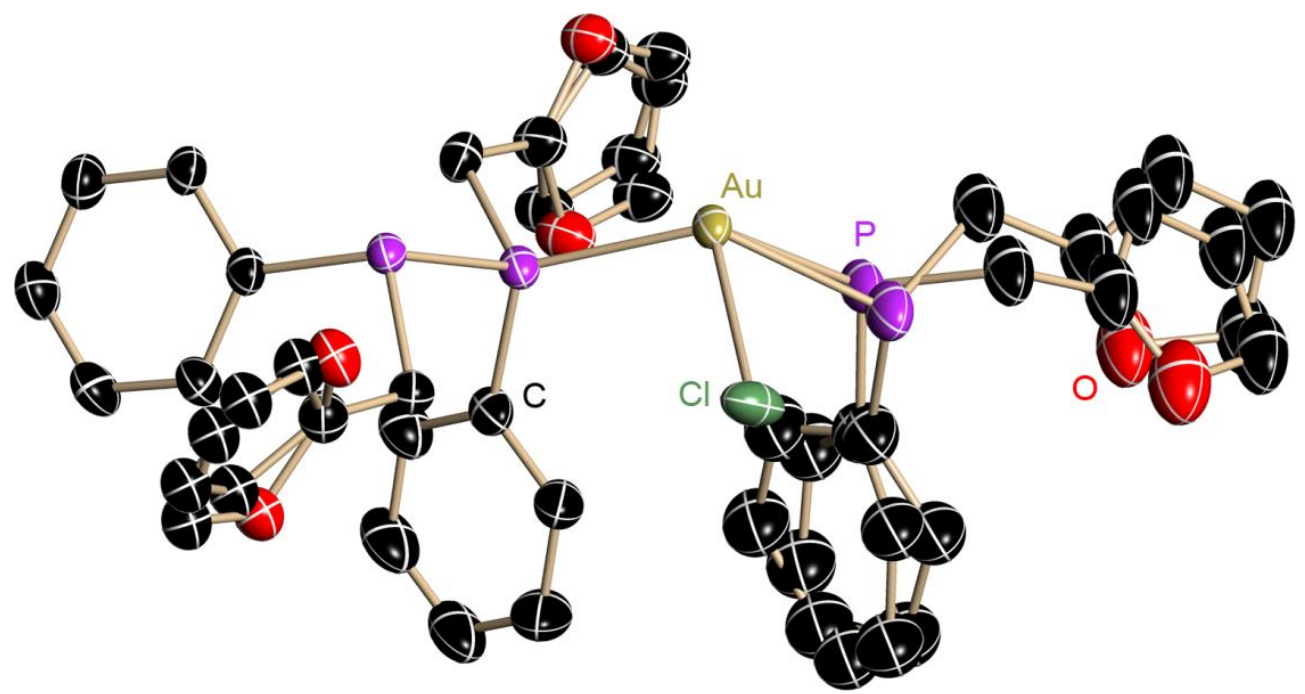

Scheme 6-16. Asymmetric unit of (23). The anisotropic displacement parameters are depicted at the $50 \%$ probability level. The hydrogen atoms, solvent toluene and the disorder of the phosphane moiety of P3 are omitted for clarity.

Disordered (fur)PhPH moiety refinded using distance and ADP restraints.

Table 6-17. Crystallographic data for 23.

\begin{tabular}{ll|ll}
\hline Id code & mg_jeg21 & $\rho_{\text {calc }}\left[\mathrm{Mg} / \mathrm{m}^{3}\right]$ & 1.635 \\
Empirical formula & $\mathrm{C}_{40} \mathrm{H}_{39} \mathrm{O}_{3} \mathrm{P}_{3} \mathrm{ClAu}$ & $\mu\left[\mathrm{mm}^{-1}\right]$ & 4.298 \\
Formula weight $[\mathrm{g} / \mathrm{mol}]$ & 893.04 & $\mathrm{~F}(000)$ & 888 \\
Crystal system & Triclinic & $\Theta$ range $\left[^{\circ}\right]$ & 1.547 to 25.072 \\
Space group & $P \overline{1}$ & Reflections collected & 30326 \\
$a[\AA]$ & $10.296(2)$ & Indep. ref. / $R_{\text {int }}$ & $6437 / 0.0609$ \\
$b[\AA]$ & $13.646(2)$ & Completeness to $\Theta_{\max }$ & $97.8 \%$ \\
$c[\AA]$ & $14.042(3)$ & Max. / min. transmission & $0.7452 / 0.6572$ \\
$\alpha\left[^{\circ}\right]$ & $99.28(2)$ & Restraints / parameters & $1593 / 626$ \\
$\beta\left[^{\circ}\right]$ & $105.79(2)$ & GoF & 1.150 \\
$\gamma\left[^{\circ}\right]$ & $101.13(2)$ & $R 1 / w R 2(\mathrm{I}>2 \sigma(\mathrm{I}))$ & $0.0487 / 0.1028$ \\
$\left.\mathrm{~V}^{\circ}\right)$ & $1814.4(6)$ & $R 1 / w R 2($ all data $)$ & $0.0656 / 0.1082$ \\
$\mathrm{Z}$ & 2 & Diff. peak and hole $\left[\AA^{3} \AA^{-3}\right]$ & $1.689 /-1.500$ \\
Crystal size $[\mathrm{mm}]$ & $0.12 \times 0.1 \times 0.1$ & & \\
\hline
\end{tabular}




\subsection{Crystallographic Cooperation}

During this $\mathrm{PhD}$ thesis service $\mathrm{X}$-ray measurements were done for Dr. Rajendra $\mathrm{S}$. Ghadwal, Dr. Ramachandran Azhakar and Dr. Prinson P. Samuel (group of Prof. Dr. Dr. h.c. mult. H. W. Roesky, University Göttingen), and Dr. Tamal Sen and Arup Mukherjee (group of A/Prof. Dr. S. K. Mandal, IISER-Kolkata), Dr. Nina Schützenmeister (group of Prof. Dr. Dr. h.c. L. F. Tietze, University Göttingen), Dr. Oliver Ries, Dr. Anatol P. Spork and Dr. Martin Büschleb (group of Prof. Dr. C. Ducho, University Göttingen, now University Paderborn), Dr. C. Brand (group of Dr. D. B. Werz, university Göttingen), Dr. V. Konstanzer (group of Prof. Dr. F. Meyer, University Göttingen), and Daniel Frank (former group of Prof. em. Dr. A. de Meijere, University Göttingen). A data set for Dr. A. Gerisch (group of Prof. Dr. M. Ruck, University Dresden) was measured on an $\mathrm{Ag}-\mathrm{I} \mu \mathrm{S}$. Data treatment and refinement was performed by A. Gerisch. ${ }^{[163]}$ The seventeen published structures are listed in Table 6-18.

Table 6-18. Published structures of crystallographic cooperation partners.

\begin{tabular}{ll}
\hline Roesky group & $763282 / 3^{[164]}, 777242 / 3^{[165]}, 780073 / 4^{[166]}$, \\
& $870572 / 3^{[167]}, 891040 / 1^{[168]}$ \\
Mandal group & $805582^{[169]}$ \\
Ducho group & $840892^{[170]}, 867825^{[171]}, 890786^{[172]}$, \\
& $791647^{[173]}$ \\
Tietze group & $879948^{[174]}$ \\
Werz group & $832491^{[175]}$ \\
\hline
\end{tabular}




\subsubsection{Unpublished structures of the Roesky group}

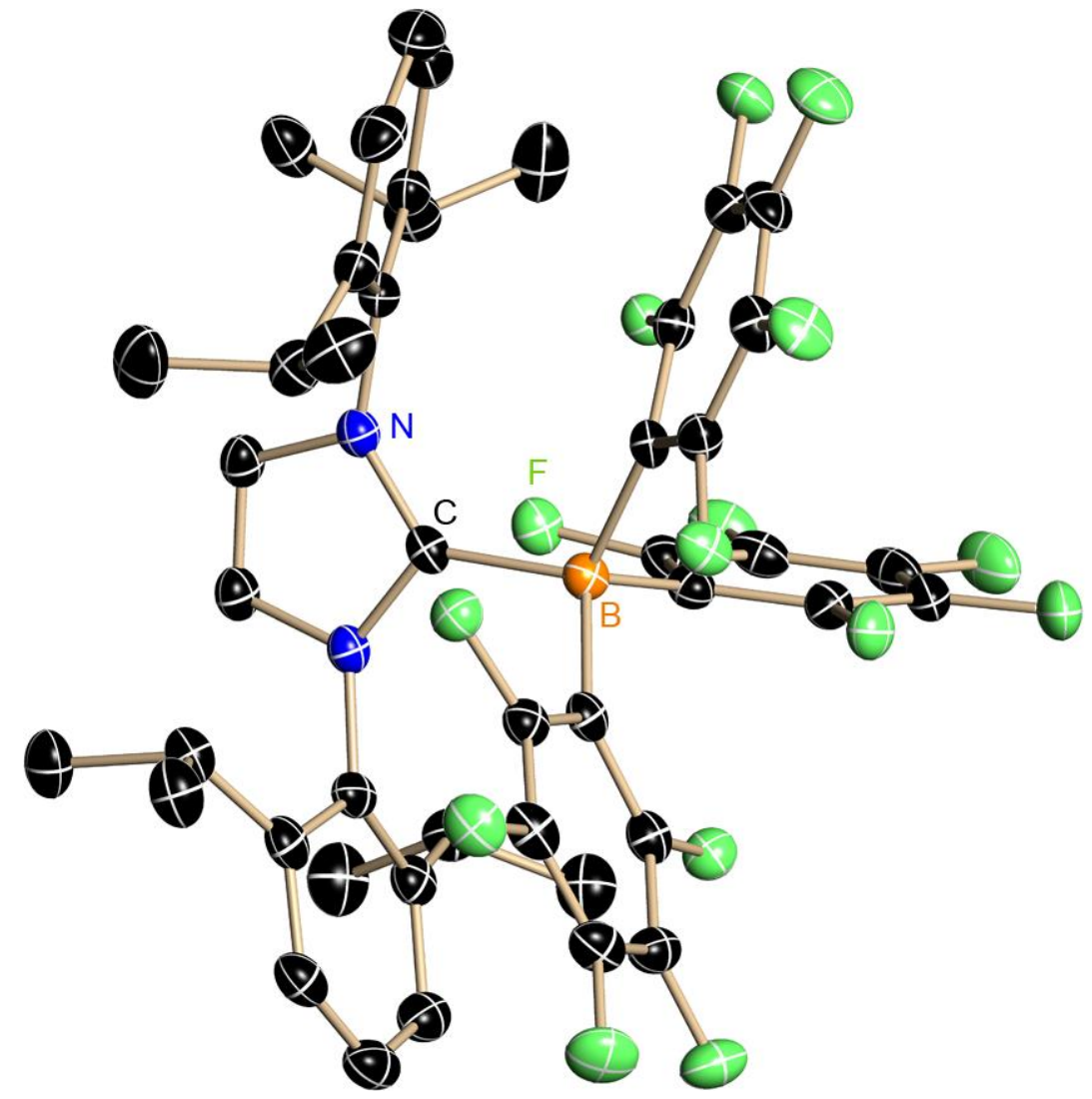

Scheme 6-17. Asymmetric unit of mg_raj_602. The anisotropic displacement parameters are depicted at the $50 \%$ probability level. The hydrogen atoms are omitted for clarity.

Table 6-19. Crystallographic data for Mg_Raj_602.

\begin{tabular}{ll|ll}
\hline Identification code & Mg_Raj_602 & $\mu\left[\mathrm{mm}^{-1}\right]$ & 0.134 \\
Empirical formula & $\mathrm{C}_{45} \mathrm{H}_{36} \mathrm{BF}_{15} \mathrm{~N}_{2}$ & $\mathrm{~F}(000)$ & 1840 \\
Formula weight $[\mathrm{g} / \mathrm{mol}]$ & 900.57 & $\Theta$ range $\left[^{\circ}\right]$ & 1.57 to 25.68 \\
Crystal system & Monoclinic & Reflections collected & 39048 \\
Space group & $P 2_{1} / c$ & Independent reflections & $7674(0.0786)$ \\
$a[\mathrm{pm}]$ & $12.036(2)$ & Completeness to $\Theta_{\max }$ & $100.0 \%$ \\
$b[\mathrm{pm}]$ & $18.592(3)$ & Max. / min. transmission & $0.9897 / 0.6286$ \\
$c[\mathrm{pm}]$ & $18.902(3)$ & Restraints / parameters & $0 / 576$ \\
$\beta\left[^{\circ}\right]$ & $107.14(3)$ & GoF & 1.016 \\
Volume $\left[\mathrm{nm}^{3}\right]$ & $4041.9(13)$ & $R 1 / w R 2(\mathrm{I}>2 \sigma(\mathrm{I}))$ & $0.0490 / 0.1234$ \\
$\mathrm{Z}$ & 4 & $R 1 / w R 2($ all data) & $0.0695 / 0.1367$ \\
Crystal size $[\mathrm{mm}]$ & $0.10 \times 0.10 \times 0.10$ & Diff. peak and hole $\left[\mathrm{e} \AA^{-3}\right]$ & 0.422 and -0.245 \\
$\rho_{\text {calc }}\left[\mathrm{Mg} / \mathrm{m}^{3}\right]$ & 1.480 & & \\
\hline
\end{tabular}




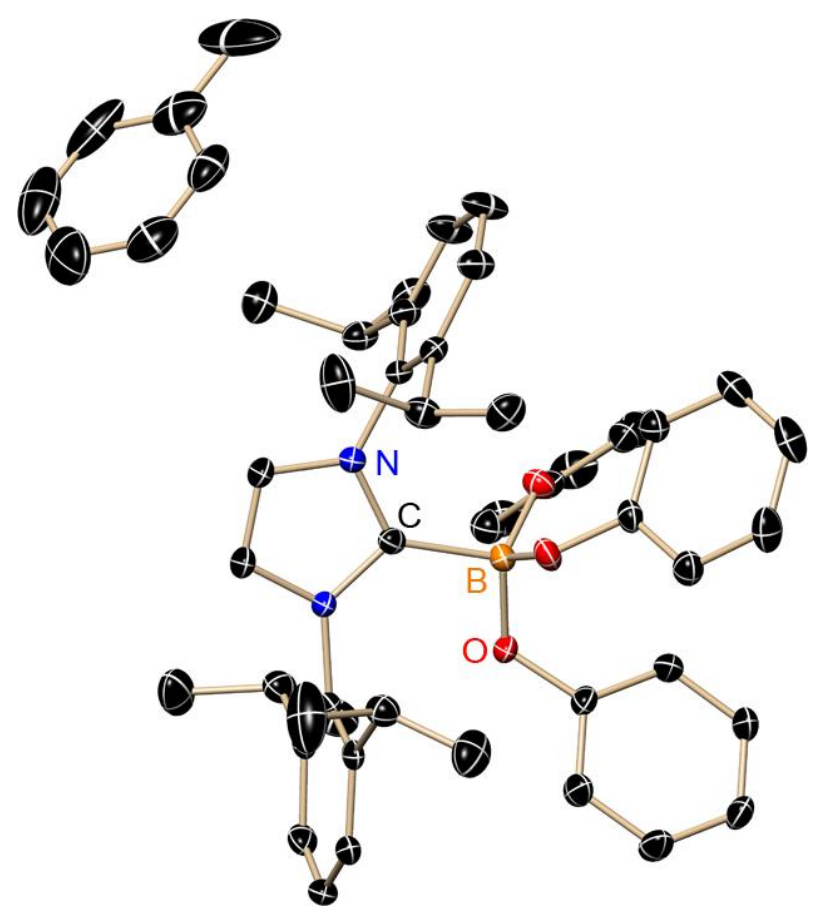

Scheme 6-18. Asymmetric unit of mg_raj_624. The anisotropic displacement parameters are depicted at the $50 \%$ probability level. The hydrogen atoms are omitted for clarity.

The disordered solvent toluene molecule was refined with ADP and distance restraints.

Table 6-20. Crystallographic data for mg_raj_624.

\begin{tabular}{|c|c|c|c|}
\hline Identification code & Mg_Raj_624 & $\rho_{\text {calc }}\left[\mathrm{Mg} / \mathrm{m}^{3}\right]$ & 1.165 \\
\hline Empirical formula & $\mathrm{C}_{48.5} \mathrm{H}_{55} \mathrm{BN}_{2} \mathrm{O}_{3}$ & $\mu\left[\mathrm{mm}^{-1}\right]$ & 0.071 \\
\hline Formula weight $[\mathrm{g} / \mathrm{mol}]$ & $2065.8(2)$ & $\mathrm{F}(000)$ & 778 \\
\hline Crystal system & Triclinic & $\Theta$ range $\left[{ }^{\circ}\right]$ & 1.00 to 26.73 \\
\hline Space group & $P \overline{1}$ & Reflections collected & 54306 \\
\hline$a[\AA]$ & $9.8131(7)$ & Independent reflections & $8764(0.0488)$ \\
\hline$b[\AA]$ & $10.3312(7)$ & Completeness to $\Theta_{\max }$ & $99.9 \%$ \\
\hline$c[\AA]$ & $20.8279(14)$ & Max. / min. transmission & 0.9804 / 0.8909 \\
\hline$\alpha\left[^{\circ}\right]$ & $100.9970(10)$ & Restraints / parameters & $59 / 520$ \\
\hline$\beta\left[^{\circ}\right]$ & $94.0360(10)$ & GoF & 1.033 \\
\hline$\gamma\left[{ }^{\circ}\right]$ & $91.5900(10)$ & $R 1 / w R 2(\mathrm{I}>2 \sigma(\mathrm{I}))$ & $0.0448 / 0.0981$ \\
\hline Volume $\left[\AA^{3}\right]$ & $2065.8(2)$ & $R 1 / w R 2$ (all data) & $0.0676 / 0.1088$ \\
\hline $\mathrm{Z}$ & 2 & Diff. peak and hole $\left[\mathrm{e} \AA^{-3}\right]$ & 0.274 and -0.253 \\
\hline Crystal size [mm] & $0.15 \times 0.14 \times 0.08$ & & \\
\hline
\end{tabular}




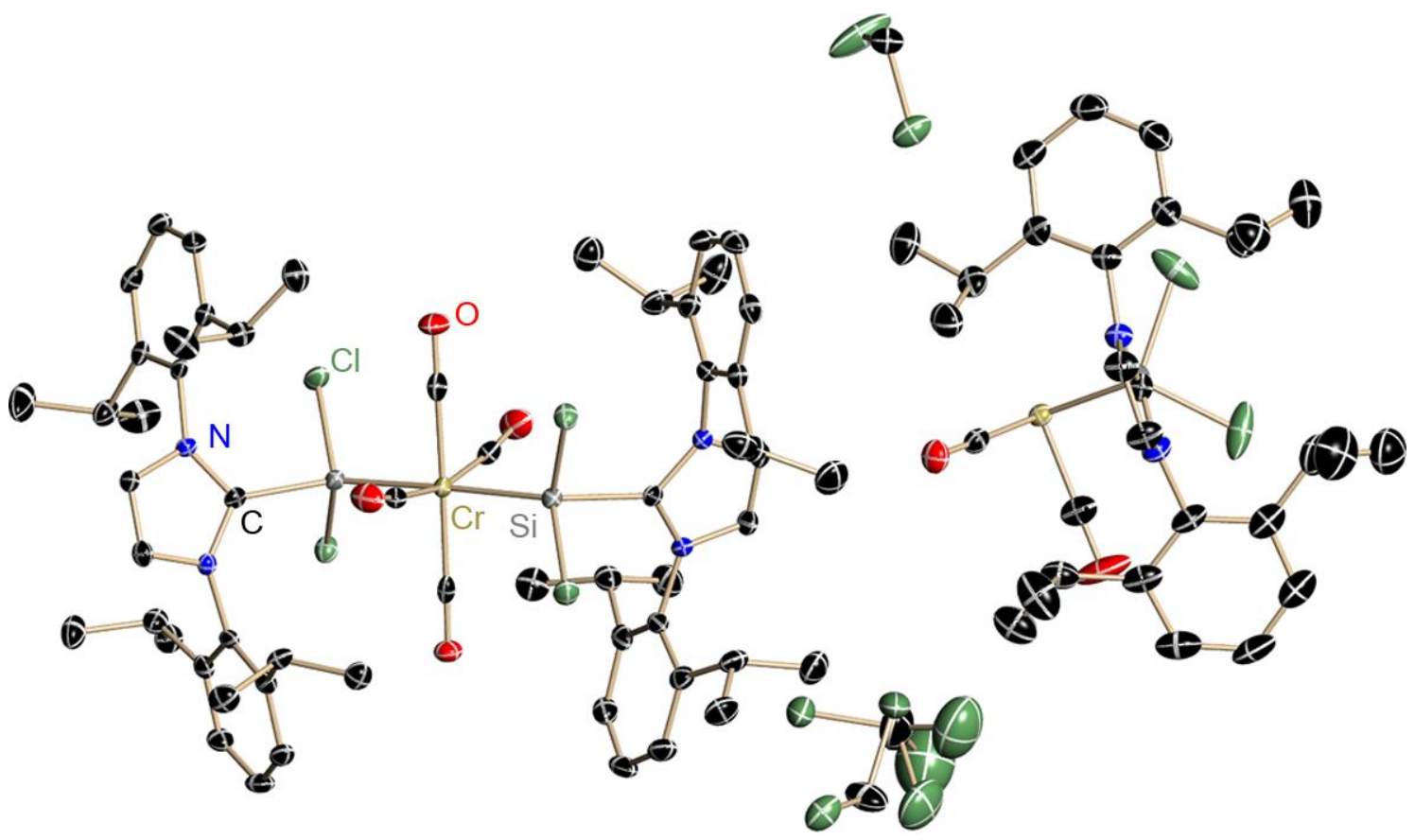

Scheme 6-19. Asymmetric unit of mg_raj_962. The anisotropic displacement parameters are depicted at the $50 \%$ probability level. The hydrogen atoms are omitted for clarity.

The disordered solvent DCM molecule was refined with ADP and distance restraints. The site occupation were refined with a free variable, respectively.

Table 6-21. Crystallographic data for mg_raj_962.

\begin{tabular}{ll|ll}
\hline Identification code & Mg_Raj_962 & $\mu\left[\mathrm{mm}^{-1}\right]$ & 0.595 \\
Empirical formula & $\mathrm{C}_{45} \mathrm{H}_{56} \mathrm{Cl}_{6} \mathrm{Cr}_{0.75} \mathrm{~N}_{3} \mathrm{O}_{3} \mathrm{Si}_{1}$ & $\mathrm{~F}(000)$ & 4096 \\
& .5 & $\Theta$ range $\left[^{\circ}\right]$ & 1.33 to 26.880 \\
Formula weight $[\mathrm{g} / \mathrm{mol}]$ & 980.76 & Reflections collected & 107376 \\
Crystal system & Monoclinic & Independent reflections & 17023 \\
Space group & $P 2_{1} / n$ & Completeness to $\Theta_{\max }$ & $93.5 \%$ \\
$a[\AA]$ & $12.437(2)$ & Max. / min. transmission & $0.9703 / 0.9071$ \\
$b[\AA]$ & $48.172(4)$ & Restraints / parameters & $39 / 1112$ \\
$c[\AA]$ & $16.726(2)$ & GoF & 1.052 \\
$\beta\left[{ }^{\circ}\right]$ & $105.67(3)$ & $R 1 / w R 2(\mathrm{I}>2 \sigma(\mathrm{I}))$ & $0.0489 / 0.0994$ \\
Volume $\left[\AA^{3}\right]$ & $9648(2)$ & $R 1 / w R 2($ all data $)$ & $0.0813 / 0.1080$ \\
$\mathrm{Z}$ & 8 & Diff. peak and hole $\left[\mathrm{e} \AA^{-3}\right]$ & 0.587 and -0.671 \\
Crystal size $[\mathrm{mm}]$ & $0.15 \times 0.14 \times 0.08$ & \\
$\rho_{\text {calc }}\left[\mathrm{Mg} / \mathrm{m}^{3}\right]$ & 1.350 & & \\
\hline
\end{tabular}



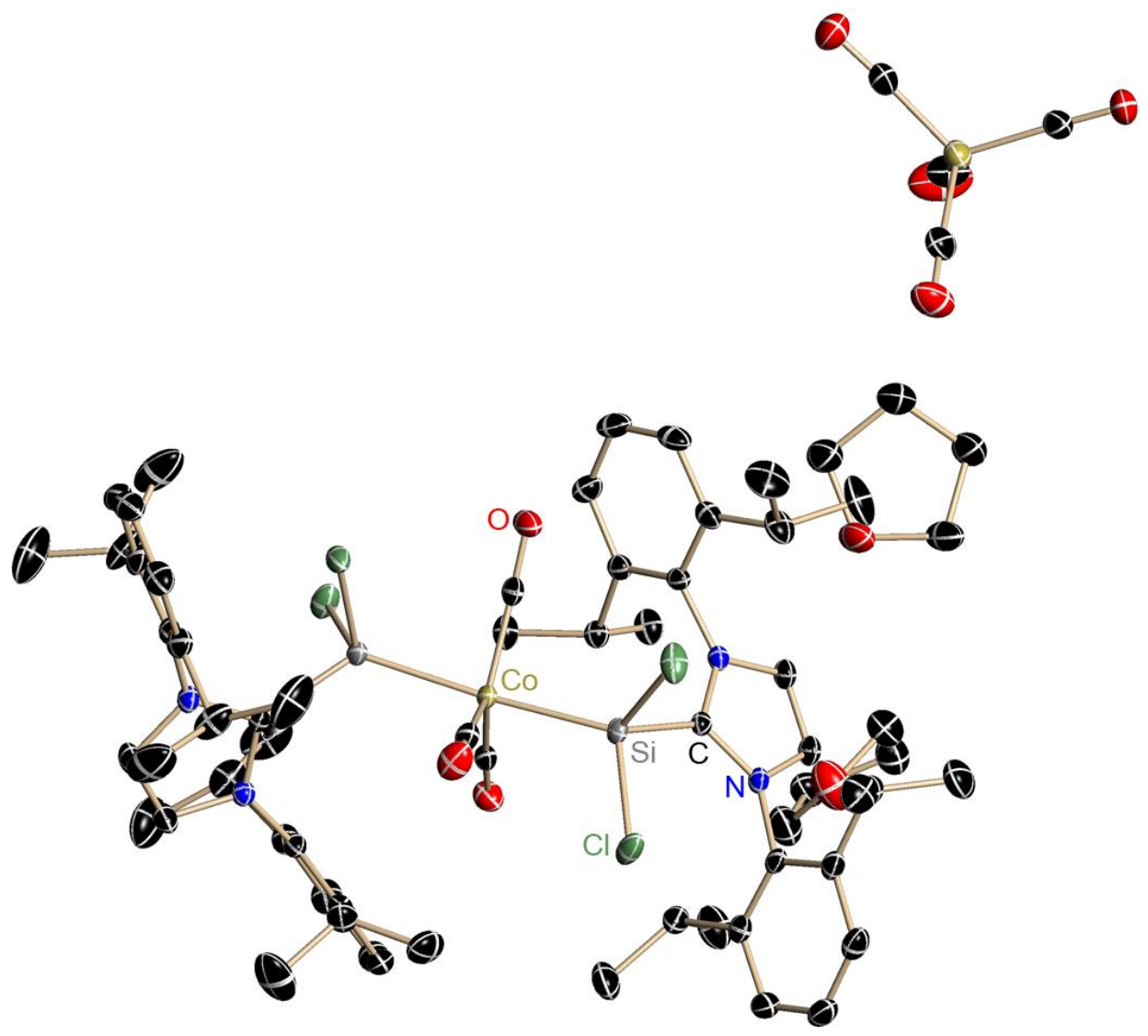

Scheme 6-20. Asymmetric unit of mg_li617. The anisotropic displacement parameters are depicted at the $50 \%$ probability level. The hydrogen atoms are omitted for clarity.

The disordered solvent thf molecules was refined with ADP and distance restraints.

Table 6-22. Crystallographic data for mg_li617.

\begin{tabular}{|c|c|c|c|}
\hline Identification code & Mg_li617 & $\rho_{\text {calc }}\left[\mathrm{Mg} / \mathrm{m}^{3}\right]$ & 1.289 \\
\hline Empirical formula & $\mathrm{C}_{69} \mathrm{H}_{88} \mathrm{~N}_{4} \mathrm{O}_{9} \mathrm{Si}_{2} \mathrm{Cl}_{4} \mathrm{Co}_{2}$ & $\mu\left[\mathrm{mm}^{-1}\right]$ & 0.681 \\
\hline Formula weight $[\mathrm{g} / \mathrm{mol}]$ & 1433.7 & $\mathrm{~F}(000)$ & 1504 \\
\hline Crystal system & Triclinic & $\Theta$ range $\left[{ }^{\circ}\right]$ & 2.060 to 27.504 \\
\hline Space group & $P \overline{1}$ & Reflections collected & 114626 \\
\hline$a[\AA]$ & $10.707(2)$ & Independent reflections & 16936 \\
\hline$b[\AA]$ & $19.049(2)$ & Completeness to $\Theta_{\max }$ & $99.9 \%$ \\
\hline$c[\AA]$ & $20.519(3)$ & Max. / min. transmission & $0.9705 / 0.9311$ \\
\hline$\alpha\left[^{\circ}\right]$ & $111.25(3)$ & Restraints / parameters & 442 / 892 \\
\hline$\beta\left[^{\circ}\right]$ & $102.03(2)$ & GoF & 1.023 \\
\hline$\gamma\left[{ }^{\circ}\right]$ & $98.85(2)$ & $R 1 / w R 2(\mathrm{I}>2 \sigma(\mathrm{I}))$ & $0.0315 / 0.0792$ \\
\hline Volume $\left[\AA^{3}\right]$ & $3692.0(12)$ & $R 1 / w R 2$ (all data) & $0.0377 / 0.0829$ \\
\hline $\mathrm{Z}$ & 2 & Diff. peak and hole $\left[\mathrm{e} \AA^{-3}\right]$ & 1.421 and -0.775 \\
\hline Crystal size $[\mathrm{mm}]$ & $0.10 \times 0.08 \times 0.08$ & & \\
\hline
\end{tabular}




\subsubsection{Unpublished structure of the Werz group}

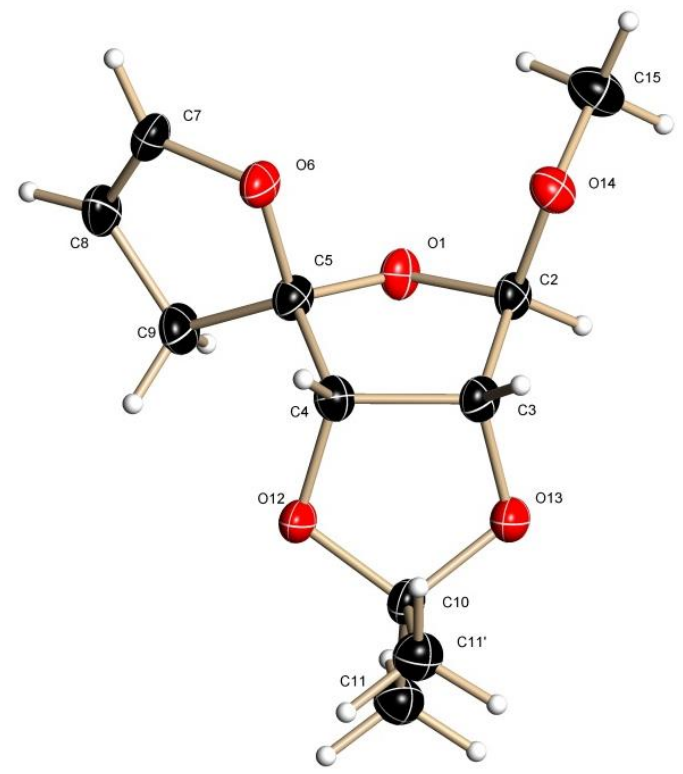

Scheme 6-21. Asymmetric unit of mg_cb01. The anisotropic displacement parameters are depicted at the $50 \%$ probability level. The hydrogen atoms are omitted for clarity.

Table 6-23. Crystallographic data for mg_cb01.

\begin{tabular}{ll|ll}
\hline IDcode / CCDC No & $\mathrm{Mg} \_\mathrm{cb} 01 / 864566$ & $\mu\left[\mathrm{mm}^{-1}\right]$ & 0.105 \\
Empirical formula & $\mathrm{C}_{11} \mathrm{H}_{16} \mathrm{O}_{5}$ & $\mathrm{~F}(000)$ & 488 \\
Formula weight $[\mathrm{g} / \mathrm{mol}]$ & 228.24 & $\Theta$ range $\left[^{\circ}\right]$ & 2.05 to 26.38 \\
Crystal system & Orthorhombic & Reflections collected & 21256 \\
Space group & $P 22_{1} 2_{1}$ & Independent reflections & 1370 \\
$a[\AA]$ & $5.568(2)$ & Completeness to $\Theta_{\max }$ & $99.7 \%$ \\
$b[\AA]$ & $12.550(2)$ & Max. / min. transmission & $0.9703 / 0.7633$ \\
$c[\AA]$ & $16.313(3)$ & Restraints / parameters & $0 / 148$ \\
Volume $\left[\AA^{3}\right]$ & $1139.9(5)$ & GoF & 1.073 \\
$Z$ & 4 & $R 1 / w R 2(\mathrm{I}>2 \sigma(\mathrm{I}))$ & $0.0380 / 0.0904$ \\
Crystal size $[\mathrm{mm}]$ & $0.25 \times 0.05 \times 0.05$ & $R 1 / w R 2$ (all data) & $0.0456 / 0.0952$ \\
$\rho_{\text {calc }}\left[\mathrm{Mg} / \mathrm{m}^{3}\right]$ & 1.330 & Diff. peak and hole $\left[\mathrm{e} \AA^{-3}\right]$ & 0.271 and -0.257 \\
& & Abs. structure parameter & - \\
\hline
\end{tabular}

The absolute structure could not be determined because of the low anomalous signal of the included atoms with Mo-radiation. $\mathrm{C} 2, \mathrm{C} 3=\mathrm{R}, \mathrm{C} 4, \mathrm{C} 5=\mathrm{S}$ confirmed by the starting material. 


\subsubsection{Unpublished structure of the Ducho group}

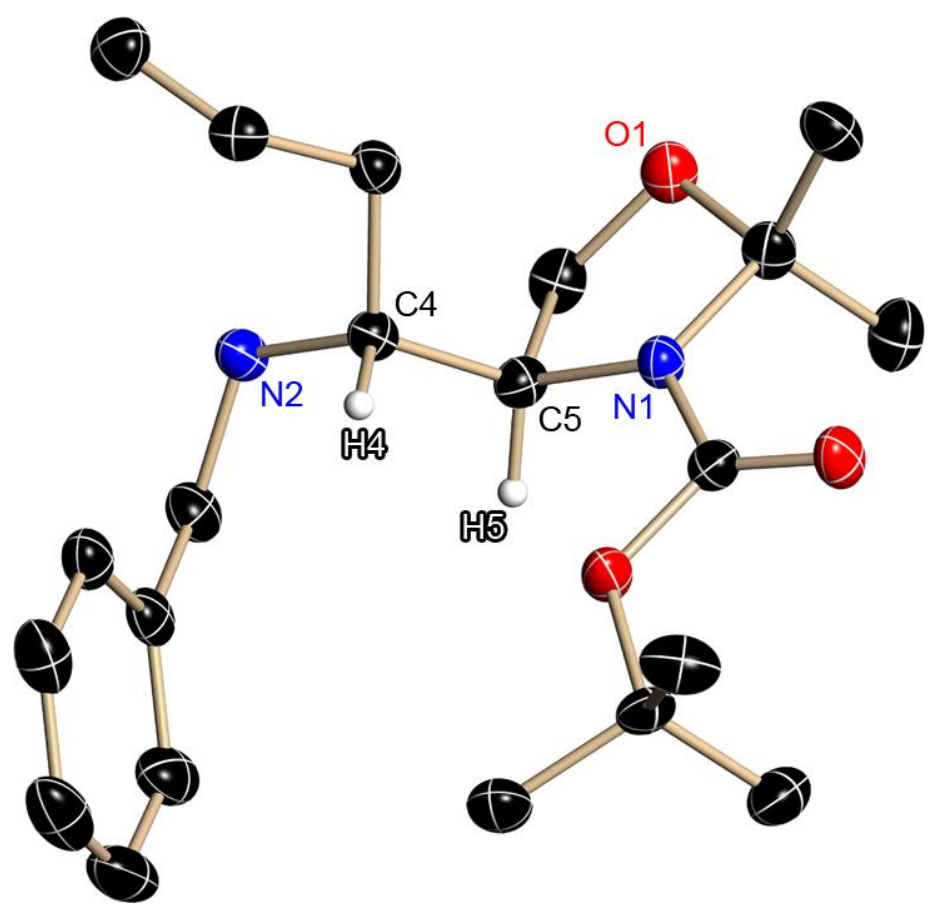

Scheme 6-22. Asymmetric unit of mg_or_4. The anisotropic displacement parameters are depicted at the $50 \%$ probability level. The hydrogen atoms, besides $\mathrm{H} 4$ and H5, are omitted for clarity.

The absolute structure could not be determined because of the low anomalous signal of the included atoms with Mo-radiation, but was confirmed by the applied starting materials. The hydrogen atoms H4 and H5 were found by difference Fourier analysis and their position were refined freely with a distance restraint. The isotropic motion of $\mathrm{H} 4$ and $\mathrm{H} 5$ were constrained 1.2 times to the $\mathrm{U}_{\mathrm{eq}}$-value of $\mathrm{C} 4$ and $\mathrm{C} 5$, respectively.

Table 6-24. Crystallographic data for mg_or_4.

\begin{tabular}{ll|ll}
\hline ID code & Mg_OR_4 & $\rho_{\text {calc }}\left[\mathrm{Mg} / \mathrm{m}^{3}\right]$ & 1.182 \\
Empirical formula & $\mathrm{C}_{21} \mathrm{H}_{32} \mathrm{~N}_{2} \mathrm{O}_{3}$ & $\mu\left[\mathrm{mm}^{-1}\right]$ & 0.079 \\
Formula weight $[\mathrm{g} / \mathrm{mol}]$ & 360.49 & $\mathrm{~F}(000)$ & 392 \\
Crystal system & Monoclinic & Reflections collected & 7061 \\
Space group & $P 2_{1}$ & Independent reflections & 2151 \\
$a[\AA]$ & $5.9158(13)$ & Completeness to $\Theta_{\max }$ & $99.5 \%$ \\
$b[\AA]$ & $13.694(3)$ & $R 1 / w R 2(\mathrm{I}>2 \sigma(\mathrm{I}))$ & $0.0331 / 0.0790$ \\
$c[\AA]$ & $12.537(3)$ & $R 1 / w R 2($ all data) & $0.0359 / 0.0803$ \\
Volume $\left[\AA^{3}\right]$ & $1013.2(4)$ & Diff. peak and hole $\left[\mathrm{e} \AA^{-3}\right]$ & 0.151 and -0.131 \\
$\mathrm{Z}$ & 2 & Abs. structure parameter & - \\
Crystal size $[\mathrm{mm}]$ & $0.14 \times 0.14 \times 0.14$ & C4:R; C5:S from synthesis & \\
\hline
\end{tabular}




\subsubsection{Unpublished structure of the Mandal group}
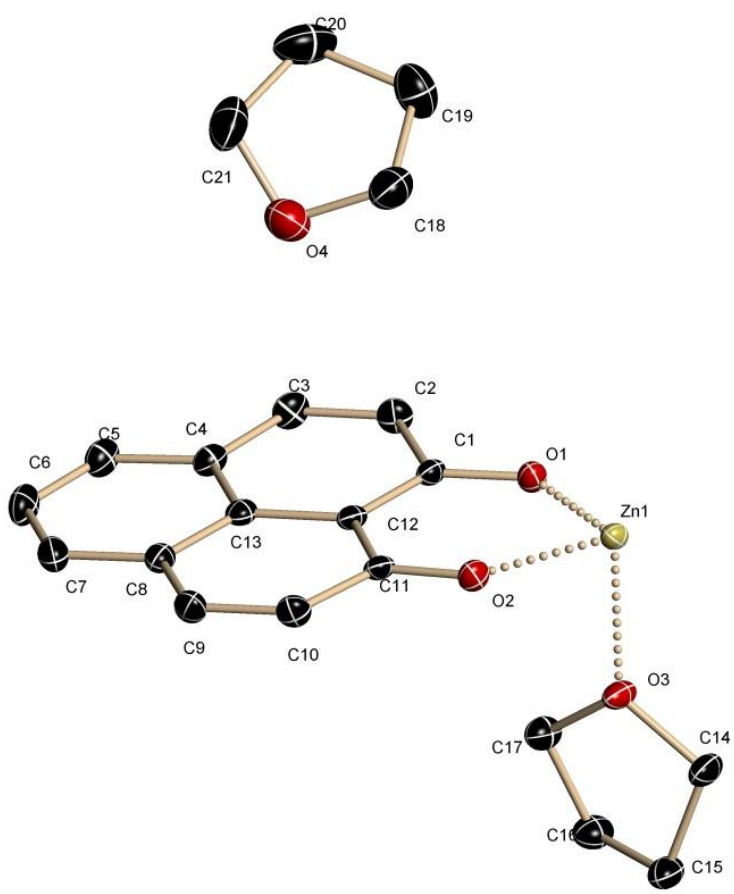

Scheme 6-23. Asymmetric unit of SM1012. The anisotropic displacement parameters are depicted at the $50 \%$ probability level. The hydrogen atoms are omitted for clarity.

Table 6-25. Crystallographic data for SM1012.

\begin{tabular}{ll|ll}
\hline ID code & $\mathrm{SM} 1012$ & $\mu\left[\mathrm{mm}^{-1}\right]$ & 0.750 \\
Empirical formula & $\mathrm{C}_{42} \mathrm{H}_{46} \mathrm{O}_{8} \mathrm{Zn}$ & $\mathrm{F}(000)$ & 784 \\
Formula weight $[\mathrm{g} / \mathrm{mol}]$ & 744.16 & $\Theta$ range $\left[^{\circ}\right]$ & 2.16 to 28.28 \\
Crystal system & Monoclinic & Reflections collected & 33694 \\
Space group & $P 2 / n$ & Independent reflections & 4393 \\
$a[\AA]$ & $9.4716(2)$ & Completeness to $\Theta_{\max }$ & $100.0 \%$ \\
$b[\AA]$ & $16.0292(4)$ & Max. / min. transmission & $0.9606 / 0.8919$ \\
$c[\AA]$ & $11.7172(3)$ & Restraints / parameters & $0 / 232$ \\
$\beta\left[{ }^{\circ}\right]$ & $96.1280(10)$ & GoF & 1.004 \\
Volume $\left[\AA^{3}\right]$ & $1768.77(7)$ & $R 1 / w R 2(\mathrm{I}>2 \sigma(\mathrm{I}))$ & $0.0368 / 0.0765$ \\
$\mathrm{Z}$ & 2 & $R 1 / w R 2($ all data) & $0.0608 / 0.0857$ \\
Crystal size $[\mathrm{mm}]$ & $0.12 \times 0.09 \times 0.09$ & Diff. peak and hole $\left[\mathrm{e} \AA^{-3}\right]$ & 0.396 and -0.406 \\
$\rho_{\text {calc }}\left[\mathrm{Mg} / \mathrm{m}^{3}\right]$ & 1.397 & & \\
\hline
\end{tabular}




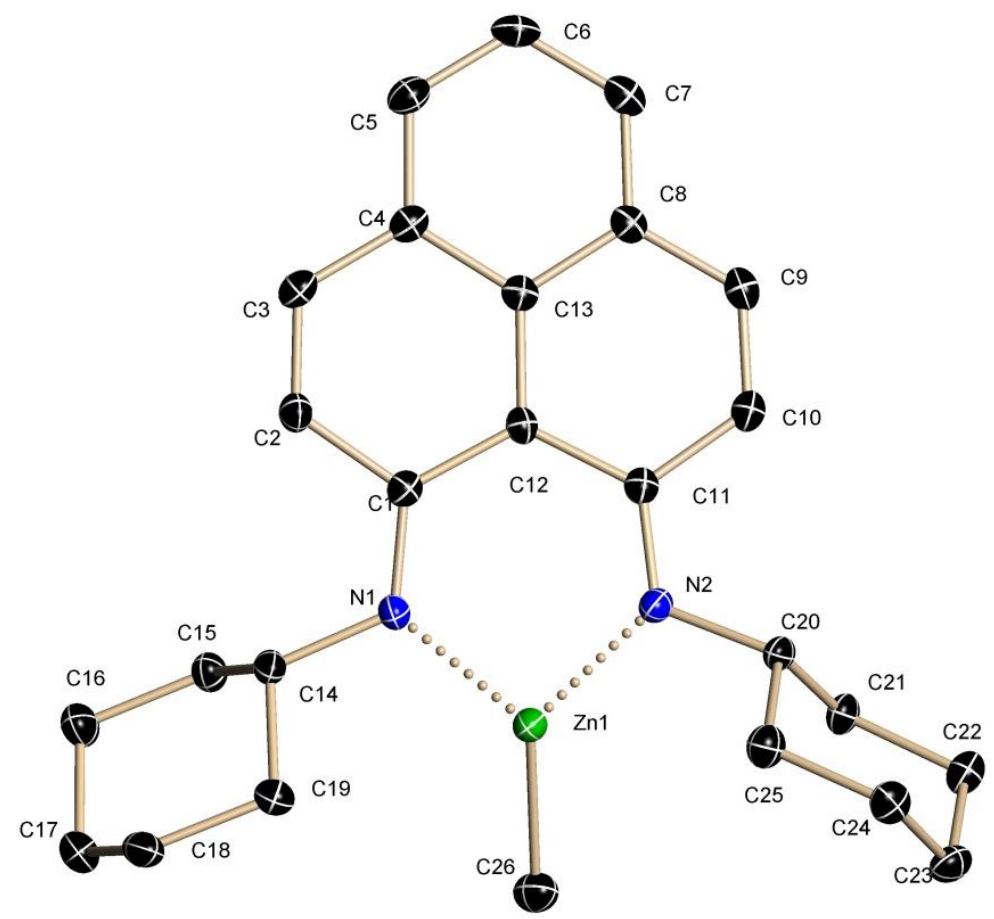

Scheme 6-24. Asymmetric unit of SM1013. The anisotropic displacement parameters are depicted at the $50 \%$ probability level. The hydrogen atoms are omitted for clarity.

Table 6-26. Crystallographic data for SM1013.

\begin{tabular}{ll|ll}
\hline ID code & $\mathrm{SM} 1013$ & $\left.\mu \mathrm{mm}^{-1}\right]$ & 1.182 \\
Empirical formula & $\mathrm{C}_{26} \mathrm{H}_{32} \mathrm{~N}_{2} \mathrm{Zn}$ & $\mathrm{F}(000)$ & 1856 \\
Formula weight $[\mathrm{g} / \mathrm{mol}]$ & 437.91 & $\Theta$ range $\left[^{\circ}\right]$ & 1.92 to 27.13 \\
Crystal system & Monoclinic & Reflections collected & 20770 \\
Space group & $C 2 / c$ & Independent reflections & 4590 \\
$a[\AA]$ & $21.5916(6)$ & Completeness to $\Theta_{\max }$ & $98.6 \%$ \\
$b[\AA]$ & $12.3044(4)$ & Max. / min. transmission & $0.9542 / 0.8161$ \\
$c[\AA]$ & $16.4599(4)$ & Restraints / parameters & $0 / 263$ \\
$\beta\left[{ }^{\circ}\right]$ & $105.688(2)$ & GoF & 1.041 \\
Volume $\left[\AA^{3}\right]$ & $4210.0(2)$ & $R 1 / w R 2(\mathrm{I}>2 \sigma(\mathrm{I}))$ & $0.0404 / 0.0927$ \\
$\mathrm{Z}$ & 8 & $R 1 / w R 2$ (all data) & $0.0605 / 0.1023$ \\
Crystal size $[\mathrm{mm}]$ & $0.10 \times 0.06 \times 0.04$ & Diff. peak and hole $\left[\mathrm{e} \AA^{-3}\right]$ & 0.374 and -0.732 \\
$\rho_{\text {calc }}\left[\mathrm{Mg} / \mathrm{m}^{3}\right]$ & 1.382 & & \\
\hline
\end{tabular}




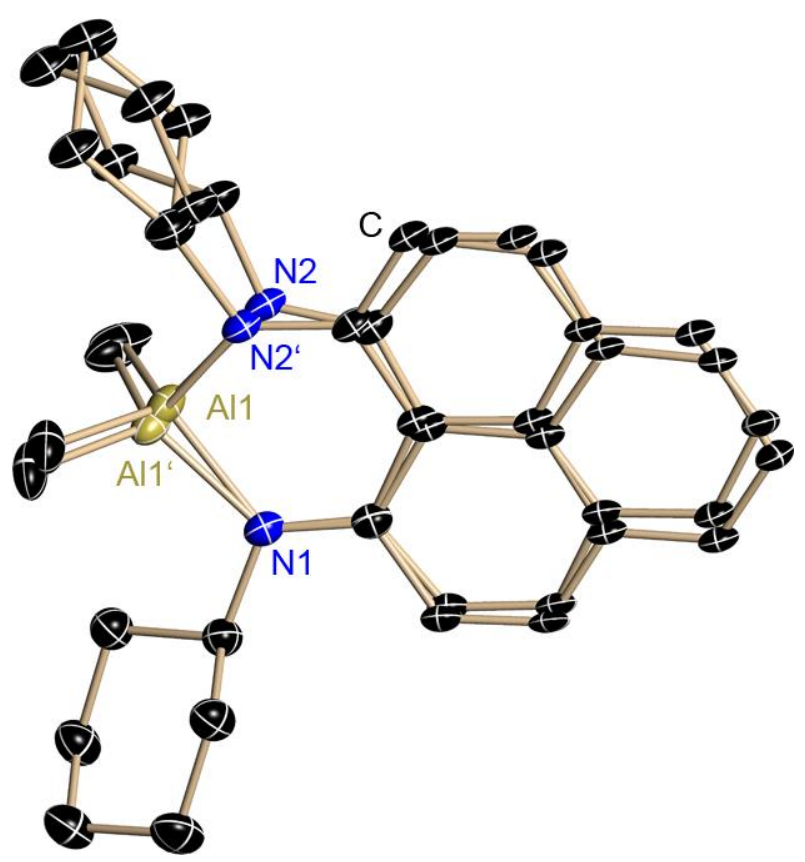

Scheme 6-25. Asymmetric unit of SM1014. The anisotropic displacement parameters are depicted at the $50 \%$ probability level. The hydrogen atoms are omitted for clarity.

The whole molecule was refined on two positions (SOF 51:49).

Table 6-27. Crystallographic data for SM1014.

\begin{tabular}{ll|ll}
\hline ID code & $\mathrm{SM} 1014$ & $\rho_{\text {calc }}\left[\mathrm{Mg} / \mathrm{m}^{3}\right]$ & 1.229 \\
Empirical formula & $\mathrm{C}_{27} \mathrm{H}_{35} \mathrm{~N}_{2} \mathrm{Al}$ & $\mu\left[\mathrm{mm}^{-1}\right]$ & 0.107 \\
Formula weight $[\mathrm{g} / \mathrm{mol}]$ & 414.55 & $\mathrm{~F}(000)$ & 448 \\
Crystal system & Triclinic & $\Theta$ range $\left[^{\circ}\right]$ & 1.81 to 26.74 \\
Space group & $P \overline{1}$ & Reflections collected & 29075 \\
$a[\AA]$ & $8.7189(5)$ & Independent reflections & 4691 \\
$b[\AA]$ & $11.8743(6)$ & Completeness to $\Theta_{\max }$ & $99.1 \%$ \\
$c\left[^{\AA} \mathrm{\AA}\right]$ & $12.5739(7)$ & Max. / min. transmission & $0.9994 / 0.9366$ \\
$\alpha\left[^{\circ}\right]$ & $67.528(3)$ & Restraints / parameters & $360 / 472$ \\
$\beta\left[^{\circ}\right]$ & $70.939(3)$ & GoF & 1.122 \\
$\gamma\left[^{\circ}\right]$ & $74.082(3)$ & $R 1 / w R 2(\mathrm{I}>2 \sigma(\mathrm{I}))$ & $0.0620 / 0.1223$ \\
$\mathrm{Volume}\left[\AA^{\circ}\right]$ & $112.22(11)$ & $R 1 / w R 2($ all data $)$ & $0.0891 / 0.1329$ \\
$\mathrm{Z}$ & 2 & Diff. peak and hole $\left[\mathrm{e} \AA^{-3}\right]$ & 0.302 and -0.302 \\
Crystal size $[\mathrm{mm}]$ & $0.10 \times 0.06 \times 0.04$ & & \\
\hline
\end{tabular}




\subsubsection{Unpublished structures of the Meyer group}

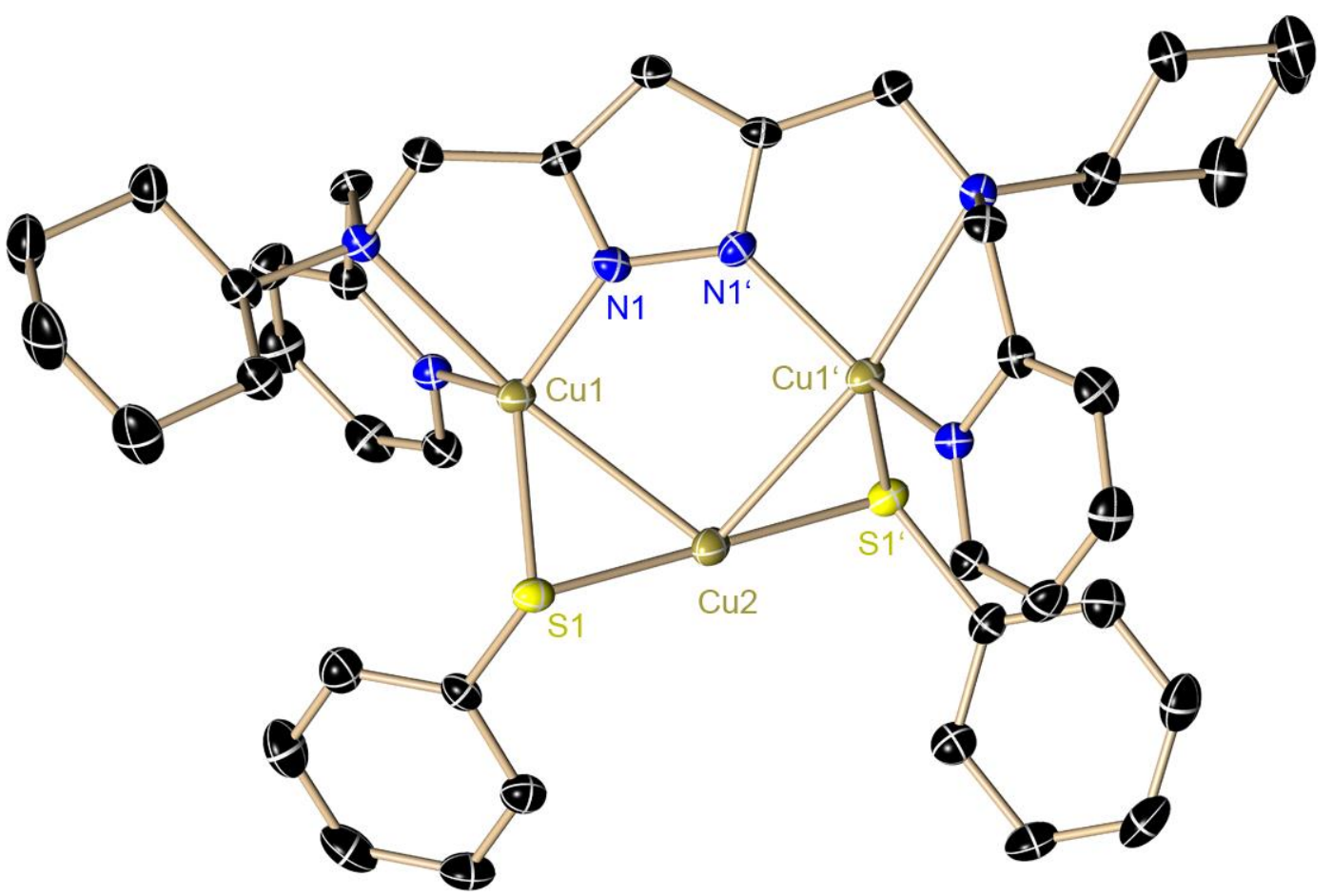

Scheme 6-26. Molecular graph of mg_vk73neu. The anisotropic displacement parameters are depicted at the $50 \%$ probability level. The hydrogen atoms and two benzene solvent molecules are omitted for clarity.

Two half molecules and two benzene molecules in the asymmetric unit.

Table 6-28. Crystallographic data for mg_vk73_neu.

\begin{tabular}{ll|ll}
\hline ID code & mg_vk73_neu & $\mu$ mm $\left.^{-1}\right]$ & 1.420 \\
Empirical formula & $\mathrm{C}_{53} \mathrm{H}_{61} \mathrm{Cu}_{3} \mathrm{~N}_{6} \mathrm{~S}_{2}$ & $\mathrm{~F}(000)$ & 4320 \\
Formula weight [g/mol] & 1036.82 & $\Theta$ range $\left.{ }^{\circ}\right]$ & 1.24 to 25.39 \\
Crystal system & Monoclinic & Reflections collected & 35149 \\
Space group & $C_{2} / c$ & Independent reflections & $8938(0.0470)$ \\
$a[\mathrm{pm}]$ & $28.506(2)$ & Completeness to $\Theta_{\max }$ & $99.2 \%$ \\
$b[\mathrm{pm}]$ & $20.594(3)$ & Max. / min. transmission & $0.9702 / 0.8654$ \\
$c[\mathrm{pm}]$ & $17.273(2)$ & Restraints / parameters & $305 / 1033$ \\
$\beta\left[^{\circ}\right]$ & $105.18(2)$ & GoF & 1.045 \\
Volume $\left[\mathrm{nm}^{3}\right]$ & $9786.3(19)$ & $R 1 / w R 2(\mathrm{I}>2 \sigma(\mathrm{I}))$ & $0.0403 / 0.0733$ \\
$\mathrm{Z}$ & 8 & $R 1 / w R 2($ all data) & $0.0657 / 0.0800$ \\
Crystal size $[\mathrm{mm}]$ & $0.12 \times 0.04 \times 0.04$ & Diff. peak and hole $\left[\mathrm{e} \AA^{-3}\right]$ & 0.493 and -0.433 \\
$\rho_{\text {calc }}\left[\mathrm{Mg} / \mathrm{m}^{3}\right]$ & 1.475 & & \\
\hline
\end{tabular}




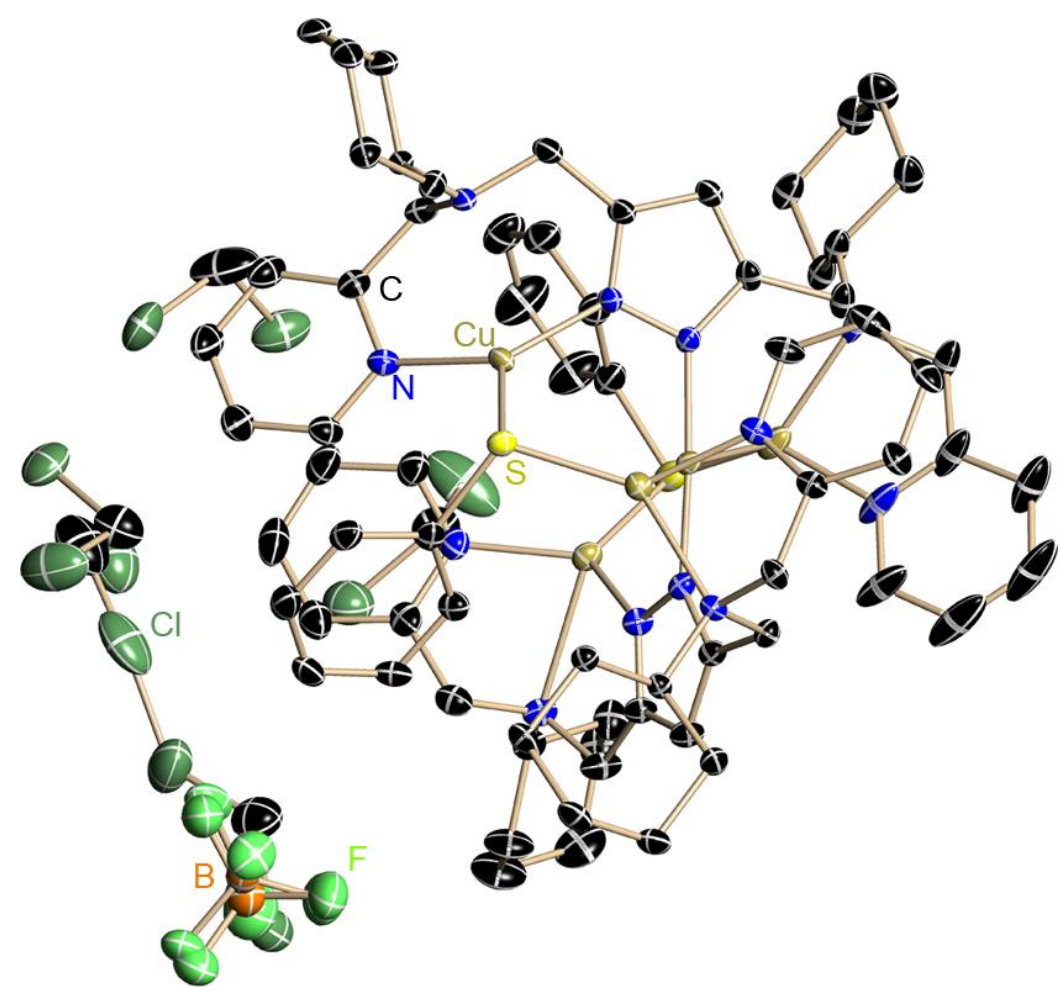

Scheme 6-27. Asymmetric unit of mgvk_279. The anisotropic displacement parameters are depicted at the $50 \%$ probability level. The hydrogen atoms are omitted for clarity.

Three dichloromethane solvents molecules are highly disordered and only partially occupied. The $\mathrm{BF}_{4}$ counter ion and the solvent disorder was refined with ADP and distance restraints.

Table 6-29. Crystallographic data for mgvk_279.

\begin{tabular}{ll|ll}
\hline ID code & mgvk_279 & $\rho_{\text {calc }}\left[\mathrm{Mg} / \mathrm{m}^{3}\right]$ & 1.475 \\
Empirical formula & $\mathrm{C}_{145.8} \mathrm{H}_{187} \mathrm{~B}_{2} \mathrm{Cl}_{11.53}$ & $\mu\left[\mathrm{mm}^{-1}\right]$ & 1.580 \\
& $\mathrm{Cu}_{10} \mathrm{~F}_{8} \mathrm{~N}_{24} \mathrm{~S}_{4}$ & & \\
Formula weight $[\mathrm{g} / \mathrm{mol}]$ & 3622.29 & $\mathrm{~F}(000)$ & 1862 \\
Crystal system & Triclinic & $\Theta$ range $\left[^{\circ}\right]$ & 1.336 to 28.381 \\
Space group & $P \overline{1}$ & Reflections collected & 66890 \\
$a[\mathrm{pm}]$ & $12.614(2)$ & Independent reflections & $20097(0.0405)$ \\
$b[\mathrm{pm}]$ & $16.514(2)$ & Completeness to $\Theta_{\max }$ & $99.8 \%$ \\
$c[\mathrm{pm}]$ & $22.108(3)$ & Max. / min. transmission & $0.9994 / 0.9366$ \\
$\alpha\left[^{\circ}\right]$ & $73.63(3)$ & Restraints / parameters & $305 / 1033$ \\
$\beta\left[^{\circ}\right]$ & $73.67(3)$ & GoF & 1.041 \\
$\gamma\left[^{\circ}\right]$ & $70.61(3)$ & $R 1 / w R 2(\mathrm{I}>2 \sigma(\mathrm{I}))$ & $0.0583 / 0.1535$ \\
$\left.V^{\circ}\right)$ & $4077.48(12) / 1$ & $R 1 / w R 2($ all data) & $0.0744 / 0.1628$ \\
Crystal size $\left.[\mathrm{mm}]^{3}\right] / \mathrm{Z}$ & $0.12 \times 0.08 \times 0.08$ & Diff. peak and hole $\left[\mathrm{e} \AA^{-3}\right]$ & 2.444 and -1.287 \\
\hline
\end{tabular}




\subsubsection{Unpublished structures of the de Meijere group}

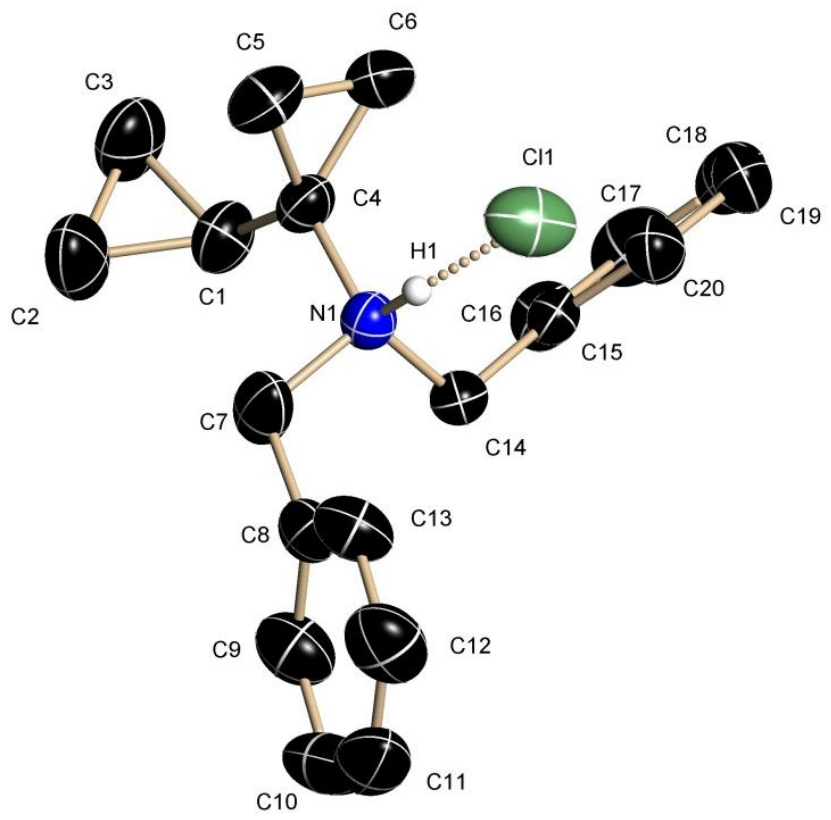

Scheme 6-28. Asymmetric unit of Mg_DF001. The anisotropic displacement parameters are depicted at the $50 \%$ probability level. The hydrogen atoms are omitted for clarity.

The hydrogen atoms H1 was found by difference Fourier analysis and its position was refined freely with a distance restraint. The isotropic motion of $\mathrm{H} 1$ was constrained 1.2 times to the $\mathrm{U}_{\mathrm{eq}}$-value of $\mathrm{N} 1$.

Table 6-30. Crystallographic data for MG_DF001.

\begin{tabular}{ll|ll}
\hline ID code & MG_DF001 & $\mathrm{F}(000)$ & 1344 \\
Empirical formula & $\mathrm{C}_{20} \mathrm{H}_{24} \mathrm{NCl}$ & $\Theta$ range $\left.{ }^{\circ}{ }^{\circ}\right]$ & 2.14 to 25.42 \\
Formula weight $[\mathrm{g} / \mathrm{mol}]$ & 313.85 & Reflections collected & 24543 \\
Crystal system & Tetragonal & Independent reflections & $3322(0.0376)$ \\
Space group & $P 4_{1} 2_{2} 2$ & Completeness to $\Theta_{\max }$ & 99.6 \\
$a$ [pm] & $9.8514(12)$ & Max. / min. transmission & $0.9166 / 0.8443$ \\
$c[\mathrm{pm}]$ & $9.8514(12)$ & Restraints / parameters & $0 / 199$ \\
Volume $\left[\mathrm{nm}^{3}\right]$ & $3605.4(8)$ & GoF & 1.036 \\
$\mathrm{Z}$ & 8 & $R 1 / w R 2(\mathrm{I}>2 \sigma(\mathrm{I}))$ & $0.0320 / 0.0788$ \\
Crystal size $[\mathrm{mm}]$ & $0.80 \times 0.5 \times 0.4$ & $R 1 / w R 2($ all data) & $0.0362 / 0.0809$ \\
$\rho_{\text {calc }}\left[\mathrm{Mg} / \mathrm{m}^{3}\right]$ & 1.159 & Diff. peak and hole $\left[\mathrm{e} \AA^{-3}\right]$ & 0.142 and -0.145 \\
$\mu\left[\mathrm{mm}^{-1}\right]$ & 0.209 & & \\
\hline
\end{tabular}




\section{Curriculum Vitae}

$\begin{array}{ll}\text { name } & \text { Markus Granitzka } \\ \text { date of birth } & 14.08 .1981 \\ \text { place of birth } & \text { Nordhorn } \\ \text { nationality } & \text { german }\end{array}$

\section{Education}

10/2008 - 02/2013 PhD student in the research group of Prof. Dietmar Stalke, GeorgAugust-Universität Göttingen.

$09 / 2008$ Diploma exam

01/2008 - 09/2008 Diploma thesis „Über fünfgliedrige heteroaromatische Lithiumorganyle“ in the research group of Prof. Dietmar Stalke, Georg-August-Universität Göttingen.

10/2006 - 03/2007 Erasmus exchange in the research group of Prof. J.-E. Bäckvall, Stockholms universitet, Sweden.

$04 / 2005$ Vordiplomprüfung, Georg-August-Universität Göttingen.

10/2002 - 09/2008 Undergraduate studies at the faculty of chemistry, Georg-AugustUniversität Göttingen.

09/2001 - 07/2002 Zivildienst at St. Marien parish in the catholic youth office, Nordhorn.

09/1994-07/2001 Gymnasium Nordhorn; Abitur.

\section{Publications}

1. O. Ries, M. Granitzka, D. Stalke, and C. Ducho, Synthetic Communications 2012, 43, 2876-2882.

Concise Synthesis and X-ray Crystal Structure of N-Benzyl-2-(pyrimidin-4'-ylamino)thiazole-4-carboxamide ('Thiazovivin'), a Small-Molecule Tool for Stem Cell Research

2. P. P. Samuel, R. Azhakar, R. S. Ghadwal, S. S. Sen, H. W. Roesky, M. Granitzka, J. Matussek, and D. Stalke, Inorganic Chemistry 2012, 51, 11049-11054.

Stable Silaimines with Three- and Four-coordinated Silicon Atoms

3. L. F. Tietze, N. Schützenmeister, A. Grube, T. Scheffer, M. M. Baag, M. Granitzka, and D. Stalke,

Eur. J. Org. Chem. 2012, 29, 5748-5756.

Synthesis of Novel Spinosyn Analogues for modern crop protection

4. R. Azhakar, R. S. Ghadwal, H. W. Roesky, M. Granitzka, D. Stalke, Organometallics 2012, 31, 5506-5510.

Reactivity Studies of N-Heterocyclic Silylene with Triphenylsilanol and Pentafluorophenol 
5. M. Granitzka, A.-C. Pöppler, E. K. Schwarze, D. Stern, T. Schulz, M. John, R. HerbstIrmer, S. K. Pandey, and D. Stalke, J. Am. Chem. Soc. 2012, 134, 1344-1351.

Aggregation of Donor Base stabilized 2-Thienyllithium in the Single Crystal and in Solution - Distances from X-ray and NOE

6. M. Büschleb, M. Granitzka, D. Stalke, C. Ducho, Amino Acids 2012, 43, 2313-2328.

A biomimetic domino reaction for the concise synthesis of capreomycidine and epicapreomycidine

7. T.K. Sen, A. Mukerjee, A. Modak, P. K. Ghorai, D. Kratzert, M. Granitzka, D. Stalke, and S.K. Mandal,

Chem. Eur. J. 2012, 18, 54-58.

Phenaylenyl-Based Molecules: Tuning the Lowest Unoccupied Molecular Orbital to Design a Catalyst

8. P. Spork, D. Wiegmann, M. Granitzka, D. Stalke, and C. Ducho, J. Org. Chem 2011, 76, 10083-10098.

Stereoselective Synthesis of Uridine-Derived Nucleosyl Amino Acids

9. C. Brand, M. Granitzka, D. Stalke, and D. B. Werz, Chem. Comm. 2011, 47, 10782-10784.

Reducing the conformational flexibility of carbohydrates: Locking the 6-hydroxyl group by cyclopropanes

10. R. S. Ghadwal, H. W. Roesky, C. Schulzke, and M. Granitzka, Organometallics 2010, 29, 6329-6333.

$\mathrm{N}$-Heterocyclic Carbene Stabilized Dichlorosilaimine $\mathrm{IPr} \cdot \mathrm{Cl}_{2} \mathrm{Si}=\mathrm{NR}$

11. R. S. Ghadwal, H. W. Roesky, M. Granitzka, and D. Stalke, J. Am. Chem. Soc. 2010, 132, 10018-10020.

A Facile Route to Functionalized N-Heterocyclic Carbenes (NHCs) with NHC BaseStabilized Dichlorosilylene

12. R. S. Ghadwal, S. S. Sen, H. W. Roesky, M. Granitzka, D. Kratzert, S. Merkel, and D. Stalke,

Angew. Chem. Int. Ed. 2010, 49, 3952-3955.

Convenient Access to Monosilicon Epoxides with Pentacoordinated Silicon

13. D. Stern, M. Granitzka, T. Schulz, D. Stalke,

Z. Naturforsch. 2010, 65b, 719-724.

Polymorphism of Dibromo-tetrakis(tetrahydrofuran- $\kappa O$ ) magnesium(II)

\section{Awards}

2012

Preis des Stiftungsrats der Georg-August-Univeristät Göttingen

"Herausragende Nachwuchswissenschaftlerpublikation"

J. Am. Chem. Soc. 2012, 134, 1344-1351. 



\section{DANKSAGUNG}

An erster Stelle möchte ich Herrn Prof. Dr. Dietmar Stalke für Freiheiten beim Anfertigen dieser Arbeit danken. Vielen Dank für die anregenden Diskussionen, das hervorragende Arbeitsklima und den Zuspruch während meiner Promotionszeit.

Herrn Prof. Dr. George M. Sheldrick danke ich für die Übernahme des Korreferats dieser Arbeit.

Des Weiteren danke ich den Mitgliedern der Prüfungskommission.

Einen großen Beitrag zur Anfertigung dieser Arbeit hat der damalige und jetzige Arbeitskreis Stalke geliefert. Ohne Euch wäre der Arbeitsalltag nicht so schön gewesen wie er war. Aus Arbeitskollegen wurden Freunde mit denen ich viele abwechslungsreiche Stunden verbringen durfte. Meinen Korrekturlesern danke ich von ganzem Herzen für ihre Mühen.

Meinen beiden Bachelors, als auch den Forschungspraktikanten danke ich für die eine oder andere unterstützende Hand im bei der Laborarbeit.

Prof. Dr. Bo B. Iversen, stellvertretend für das CMC, danke ich für die Zusammenarbeit, die Beamline-Erfahrung und die finanzielle Unterstützung.

Meiner Familie und meinen Freunden danke ich für die Unterstützung und den Rückhalt während der Doktorarbeit und die schönen Tage, die wir hatten. Mein größter Dank gilt Dir, Barbara. Danke dafür, dass Du immer für mich da bist.

I forgot you? Well... thank you for being there!!! 



\section{REFERENCES}

[1] a) T. T. Tidwell, Angew. Chem. 2001, 113, 343-349; Angew. Chem. Int. Ed., 40, 331-337; b) W. Schlenk, J. Holtz, Ber. Dtsch. Chem. Ges. 1917, 50, 262-274; c) D. Seyferth, Organometallics 2009, 28, 2-33; d) W. Schlenk, A. Thal, Ber. Dtsch. Chem. Ges. 1913, 46, 2840-2854.

[2] a) B. J. Wakefield, The Chemistry of Organolithium Compounds 1974; b) M. Schlosser, in Organometallics in Synthesis - A Manual, 2nd ed. (Ed.: M. Schlosser), John Wiley \& Sons Ltd., Chichester, 2004, pp. 1-352; c) L. Brandsma, in Preparative Polar Organometallic Chemistry, Vol. Vol. 2, Springer, Berlin, 1990, p. 195; d) L. Brandsma, H. D. Verkruijsse, in Preparative Polar Organometallic Chemistry, Vol. Vol. 1, Springer, Berlin, 1987; e) C. Elschenbroich, Organometallchemie 2008, 6,

[3] R. E. Dinnebier, U. Behrens, F. Olbrich, J. Am. Chem. Soc. 1998, 120, 1430-1433.

[4] H. Hope, Acta Crystallogr., Sect. B. 1988, 44, 22-26.

[5] D. Thoennes, E. Weiss, Chem. Ber. 1978, 111, 3157-3161.

[6] U. Schümann, J. Kopf, E. Weiss, Angew. Chem. 1985, 97, 222-223; Angew. Chem. Int. Ed. Engl., 24, 215-216.

[7] T. Kottke, D. Stalke, Angew. Chem. 1993, 105, 619-621; Angew. Chem. Int. Ed. Engl., 32, 580582.

[8] C. Strohmann, V. H. Gessner, Chem. Asian J. 2008, 3, 1929-1934.

[9] G. Wittig, Angew. Chem. 1958, 70, 65-71;

[10] R. Michel, R. Herbst-Irmer, D. Stalke Organometallics 2011, 30, 4379-4386.

[11] C. Eaborn, P. B. Hitchcock, J. D. Smith, A. C. Sullivan, J. Chem. Soc., Chem. Commun. 1983, $827-$ 828.

[12] A. C. Jones, A. W. Sanders, W. H. Sikorski, K. L. Jansen, H. J. Reich, J. Am. Chem. Soc. 2008, 130, 6060-6061.

[13] D. J. Peterson, J. Org. Chem. 1968, 33, 780-784.

[14] M. D. Rausch, D. J. Ciappenelli, J. Organomet. Chem. 1967, 10, 127-136.

[15] T. Tatic, S. Hermann, M. John, A. Loquet, A. Lange, D. Stalke, Angew. Chem. 2011, 123, 67966800; Angew. Chem. Int. Ed., 50, 6666-6670.

[16] A. Krasovskiy, P. Knochel, Angew. Chem. 2004, 116, 3396-3399; Angew. Chem. Int. Ed., 43, 3333-3336.

[17] a) V. Grignard, C. R. Acad. Sci. 1901, 132, 835-837; b) V. Grignard, C. R. Acad. Sci. 1900, 130, 1322-1324.

[18] Argonne National Laboratory, U.S. Department of Energy Office of Sciene, www.aps.anl.gov, 28.11.2012.

[19] a) P. Knochel, W. Dohle, N. Gommermann, F. F. Kneisel, F. Kopp, T. Korn, I. Sapountzis, V. A. Vu, Angew. Chem. 2003, 115, 4438-4456; Angewandte Chemie Int. Ed., 42, 4302-4320; b) F. M. Piller, A. Metzger, M. A. Schade, B. A. Haag, A. Gavryushin, P. Knochel, Chem. Eur. J. 2009, 15, 7192-7202; c) S. H. Wunderlich, M. Kienle, P. Knochel, Angew. Chem. 2009, 121, 7392-7396; Angew. Chem. Int. Ed., 48, 7256-7260.

[20] D. R. Armstrong, P. Garcia-Alvarez, A. R. Kennedy, R. E. Mulvey, J. A. Parkinson, Angew. Chem. 2010, 122, 3263-3256; Angew. Chem. Int. Ed., 49, 3185-3188.

[21] a) F. Blasberg, M. Bolte, M. Wagner, H.-W. Lerner, Organometallics 2012, 31, 1001-1005; b) S. E. Baillie, W. Clegg, P. Garcia-Alvarez, E. Hevia, A. R. Kennedy, J. Klett, L. Russo, Organometallics 2012, 31, 5131-5142. [and references therein]

[22] E. R. Biehl, Progr. Heterocyc. Chem. 2011, 22, 109-141.

[23] R. Chinchilla, C. Nájera, M. Yus, ARKIVOC 2007, 10, 152-231.

[24] V. L. Blair, A. R. Kennedy, R. E. Mulvey, C. T. O'Hara, Chem. Eur. J. 2010, 16, 8600-8604.

[25] D. Belo, M. Almeida, Coord. Chem. Rev. 2010, 254, 1479-1492.

[26] I. F. Perepichka, in Handbook of Thiophene-Based Materials: Applications in Organic Electronics and Photonics, Vol. 1 (Eds.: I. F. Perepichka, D. F. Perepichka), John Wiley \& Son, Chichester (GB), 2009.

[27] Y. Liu, Y. Liu, X. Zahn, Macromol. Chem. Phys. 2011, 212, 428-443.

[28] F. Petti, A. Thelemann, J. Kahler, S. McCormack, L. Castaldo, T. Hunt, L. Nuwaysir, L. Zeiske, H. Haack, L. Sullivan, A. Garton, J. D. Haley, Mol. Cancer Ther. 2005, 4, 1186-1197. 
[29] N. Sweeney, W. M. Gallagher, H. Müller-Bunz, C. Pampillón, K. Strohfeldt, M. Tacke, J. Inorg. Biochem. 2006, 100, 1479-1486.

[30] C. Selinka, D. Stalke, Eur. J. Inorg. Chem. 2003, 3376-3382.

[31] C. Selinka, D. Stalke, Z. Naturforsch. 2003, 58b, 291-298.

[32] B. Cornils, W. A. Herrmann, M. Muhler, in Catalysis from A to Z: a concise encyclopedia, WileyVCH, Weinheim, 2007.

[33] a) K. B. Sharpless, Angew. Chem. 2002, 114, 2124-2135; Angew. Chem. Int. Ed., 41, 2024-2035; b) R. Noyori, Angew. Chem. 2002, 114, 2108-2123; Angew. Chem. Int. Ed., 41, 2008-2022; c) W. S. Knowles, Angew. Chem. 2002, 114, 2096-2107; Angew. Chem. Int. Ed., 41, 1998-2007.

[34] X.-F. Wu, P. Anbarasam, H. Neumann, M. Beller, Angew. Chem. 2010, 122, 9231-9234; Angew. Chem. Int. Ed., 49, 9047-9050.

[35] a) E.-I. Negishi, Angew. Chem. 2011, 123, 6870-6897; Angew. Chem. Int. Ed., 50, 6738-6764; b) E.-I. Negishi, Acc. Chem. Res. 1982, 15, 340-348; c) Y. Tamaru, in Modern Organonickel Chemistry, Wiley-VCH, Weinheim, 2005; d) K. Weissermel, H.-J. Arpe, in Industrial Organic Chemistry, Vol. 3rd, Wiley-VCH, Weinheim, 1997; e) M. Raney, US patent 1628190, 1927.

[36] a) B. H. Lipshutz, in Organometallics in Synthesis - A Manual, 2nd Ed. ed. (Ed.: M. Schlosser), John Wiley \& Sons, Chichester, 2004, pp. 665-815; b) C. Deutsch, N. Krause, B. H. Lipshutz, Chem. Rev. 2008, 108, 2916-2927; c) T. Punniyamurthy, R. Laxmidhar, Coord. Chem. Rev. 2008, 252, 134-154; d) S. Reymond, J. Cossy, Chem. Rev. 2008, 108, 5359-5406; e) H. Rao, H. Fu, Synlett 2011, 6, 745-769.

[37] a) G. Helmchen, A. Pfaltz, Acc. Chem. Res. 2000, 33, 336-345; b) X. Cui, K. Burgess, Chem. Rev. 2005, 105, 3272-3296; c) K. Källström, I. Munslow, P. G. Andersson, Chem. Eur. J. 2006, 12, 3194-3200; d) J. Meiners, A. Friedrich, E. Herdtweck, S. Schneider, Organometallics 2009, 28, 6331-6338; e) J. Meiners, M. G. Scheibel, M.-H. Lemée-Cailleau, S. A. Mason, M. B. Boeddinghaus, T. F. Fässler, E. Herdtweck, M. M. Khusniyarov, S. Schneider, Angew. Chem. 2011, 123, 8334-8337; Angew. Chem. Int. Ed., 50, 8184-8187; f) M. G. Scheibel, B. Askevold, F. W. Heinemann, E. J. Reijerse, B. de Bruin, S. Schneider, Nat. Chem. 2012, 4, 552-558.

[38] a) A. S. K. Hashmi, Chem. Rev. 2007, 107, 3180-3211; b) Z. Li, C. Brouwer, C. He, Chem. Rev. 2008, 108, 3239-3265; c) T.-M. Teng, R.-S. Liu, J. Am. Chem. Soc. 2010, 132, 9298-9300; d) M. Rudolph, A. S. K. Hashmi, Chem. Commun. 2011, 47; e) H. A. Wegner, M. Auzias, Angew. Chem. 2011, 123, 8386-8397; Angew. Chem. Int. Ed., 50, 8236-8247; f) M. Rudolph, A. S. K. Hashmi, Chem. Soc. Rev. 2012, 41, 2448-2462.

[39] J. C. Jeffrey, T. B. Rauchfuss, Inorg. Chem. 1979, 18, 2658-2666.

[40] a) R. G. Parr, R. G. Pearson, J. Am. Chem. Soc. 1983, 105, 7512-7516; b) R. G. Pearson, J. Am. Chem. Soc. 1963, 85, 3533-3539.

[41] I. Objartel, H. Ott, D. Stalke, Z. Anorg. Allg. Chem. 2008, 634, 2373-2379.

[42] a) A. Murso, D. Stalke, Z. Anorg. Allg. Chem. 2004, 630, 1025-1030; b) A. Murso, D. Stalke, Eur. J. Inorg. Chem. 2004, 4272-4277; c) C. Kling, H. Ott, G. Schwab, D. Stalke, Organometallics 2008, 27, 5038-5042.

[43] a) H. Gornitzka, D. Stalke, Angew. Chem. 1994, 106, 695-697; Angew. Chem. Int. Ed. Engl., 33, 693-695; b) H. Gornitzka, D. Stalke, Organometallics 1994, 13, 4398-4405.

[44] M. Pfeiffer, F. Baier, T. Stey, D. Leusser, D. Stalke, B. Engels, D. Moigno, W. Kiefer, J. Mol. Model. 2000, 6, 299-311.

[45] a) F. Baier, Z. Fei, H. Gornitzka, A. Murso, S. Neufeld, M. Pfeiffer, I. Rüdenauer, A. Steiner, T. Stey, D. Stalke, J. Organomet. Chem. 2002, 661, 111-127; b) L. Mahalakshmi, D. Stalke, in Structure and Bonding - Group 13 Chemistry I, Vol. 103 (Ed.: H. W. R. D. A. Atwood), Springer Verlag, Heidelberg, 2002, pp. 85-115; c) A. Steiner, D. Stalke, J. Chem. Soc., Chem. Commun. 1993, 444-446; d) A. Steiner, D. Stalke, Organometallics 1995, 14, 2422-2429; e) M. Pfeiffer, T. Stey, H. Jehle, B. Klüpfel, W. Malisch, D. Stalke, V. Chandrasekhar, Chem. Commun. 2001, 4, 337-338.

[46] a) C. Kling, D. Leusser, T. Stey, D. Stalke, Organometallics 2011, 30, 2461-2463; b) T. Stey, M. Pfeiffer, J. Henn, S. K. Pandey, D. Stalke, Chem. Eur. J. 2007, 13, 3636-3642; c) T. Stey, J. Henn, D. Stalke, Chem. Commun. 2007, 413-415; d) T. Stey, D. Stalke, Z. Anorg. Allg. Chem. 2005, 651, 2931-2936; e) T. Stey, Germany (Universität Würzburg), 2004.

[47] a) M. Veith, S. Weidner, K. Kunze, D. Käfer, J. Hans, V. Huch, Coord. Chem. Rev. 1994, 137, $297-$ 322; b) I. Objartel, N. A. Pott, M. John, D. Stalke, Organometallics 2010, 29, 5670-5675; c) M. M. 
Meinholz, S. K. Pandey, S. M. Deuerlein, D. Stalke, Dalton Trans. 2011, 40, 1662-1671; d) I. Kuzu, I. Krummenacher, J. Meyer, F. Armbruster, F. Breher, Dalton Trans. 2008, 5836-5865.

[48] A. L. Spek, N. Veldman, 1999, private communication to the CCDC (113903).

[49] D. R. Powell, W. L. Whipple, H. J. Reich, Acta Crystallogr., Sect. C. 1996, 52, 1346-1348.

[50] a) H. J. Reich, W. L. Whipple, Can. J. Chem. 2005, 83, 1577-1587; b) K. L. Jantzi, C. L. Puckett, I. A. Guzei, H. J. Reich, J. Org. Chem. 2005, 70, 7520-7529.

[51] A. L. Spek, M. T. Lakin, R. den Besten, 1999, Private Communication to the CCDC (138502).

[52] A. L. Spek, W. J. J. Smeets, 1999, Private Communication to the CCDC (113718).

[53] A. L. Spek, 1999, Private Communication to the CCDC (114029).

[54] S. Harder, J. Boersma, L. Brandsma, J. A. Kanters, W. Bauer, R. Pi, P. v. R. Schleyer, H. Schöllborn, U. Thewalt, Organometallics 1989, 8, 1688-1696.

[55] K. Shen, Y. Fu, J.-N. Li, L. Liu, Tetrahedron 2007, 63, 1568-1576.

[56] M. Granitzka, A.-C. Pöppler, E. K. Schwarze, D. Stern, T. Schulz, M. John, R. Herbst-Irmer, S. K. Pandey, D. Stalke J. Am. Chem. Soc. 2012, 134, 1344-1351.

[57] A.-C. Pöppler, 2013, Doktorarbeit, in Progress.

[58] a) D. Stalke, Chem. Soc. Rev. 1998, 27, 171-178; b) T. Kottke, R. J. Lagow, D. Stalke, J. Appl. Crystallogr. 1996, 29, 465-468; c) T. Kottke, D. Stalke, J. Appl. Crystallogr. 1993, 26, 615-619.

[59] a) V. H. Gessner, C. Däschlein, C. Strohmann, Chem. Eur. J. 2009, 15, 3320-3334; b) T. Stey, D. Stalke, in The chemistry of organolithium compounds (Eds.: Z. Rappoport, I. Marek), John Wiley \& Sons, Chichester (GB), 2004, pp. 47-120; c) E. Weiss, Angew. Chem. 1993, 105, 1565-1587; Angew. Chem. Int. Ed. Engl., 32, 1501-1523; d) W. N. Setzer, P. v. R. Schleyer, Adv. Organomet. Chem. 1985, 24, 353-451; e) P. v. R. Schleyer, Pure Appl. Chem. 1983, 55, 355-362.

[60] a) D. Stalke Chem. Eur. J. 2011, 17, 9264-9278; b) R. F. W. Bader, in Atoms in Molecules, Oxford University Press, New York, 1990; c) R. F. W. Bader, J. Phys. Chem. A 1998, 102, 7314-7323.

[61] S. Deuerlein, D. Leusser, U. Flierler, H. Ott, D. Stalke, Organometallics 2008, 27, 2306-2315.

[62] a) E. Matito, J. Poater, F. M. Bickelhaupt, M. Solà, J. Phys. Chem. 2006, B110, 7189-7198; b) F. M. Bickelhaupt, M. Solà, C. F. Guerra, J. Chem. Theory Comput. 2006, 2, 965-980; c) C. Lambert, P. von Ragué Schleyer, Angew. Chem. 1994, 106, 1187-1199; Angew. Chem. Int. Ed. Engl., 33, 1129-1140.

[63] C. H. o. C. a. Physics, in CRC Handbook of Chemistry and Physics, 87 ed. (Ed.: D. R. Lide), Taylor \& Francis, Boca Raton, 2006, pp. 8-18.

[64] D. Stern, N. Finkelmeier, K. Meindl, J. Henn, D. Stalke Angew. Chem. 2010, 120, 7021-7024; Angew. Chem. Int. Ed., 49, 6869-6872.

[65] M. Granitzka, Diploma thesis, Deutschland (Göttingen), 2008.

[66] D. Stalke, K. H. Whitmire, Chem. Commun. 1990, 833-834.

[67] B. Schiemenz, P. P. Power, Angew. Chem. 1996, 108, 2288-2290; Angew. Chem. Int. Ed. Engl., 35, 2150-2152.

[68] H. Hope, P. P. Power, J. Am. Chem. Soc. 1983, 105, 5320-5324.

[69] C. Strohmann, T. Seibel, K. Strohfeldt, Angew. Chem. 2003, 115, 4669-4671; Angew. Chem. Int. Ed., 42, 4531.

[70] D. B. Collum, Acc. Chem. Res. 1992, 25, 448-454.

[71] a) J. S. DePue, D. B. Collum, J. Am. Chem. Soc. 1988, 110, 5518-5524; b) J. S. DePue, D. B. Collum, J. Am. Chem. Soc. 1988, 110, 5524-5533; c) A. S. Galiano-Roth, D. B. Collum, J. Am. Chem. Soc. 1989, 111, 6772-6778; d) J. F. Remenar, D. B. Collum, J. Am. Chem. Soc. 1998, 120, 4081-4086.

[72] a) D. Hoffmann, W. Bauer, P. v. R. Schleyer, U. Pieper, D. Stalke, Organometallics 1993, 12, 1193-1200; b) F. T. Edelmann, F. Knösel, F. Pauer, D. Stalke, W. Bauer, J. Organomet. Chem. 1992, 438, 1-10.

[73] a) D. Seebach, R. Hässig, J. Gabriel, Helv. Chim. Acta 1983, 66, 308-337; b) M. Kühnen, H. Günther, J.-P. Amoureux, C. Fernández, Magn. Res. Chem. 2002, 40, 24-30; c) G. Fraenkel, A. Chow, J. Am. Chem. Soc. 1990, 112, 6190-6198.

[74] a) W. H. Sikorski, A. W. Sanders, H. J. Reich, Magn. Res. Chem. 1998, 36, 118-124; b) J. Cavanagh, W. J. Fairbrother, A. G. Palmer III., M. Rance, N. J. Skelton, in Protein NMR Spectroscopy - Principles and Practice, 2 ed., Elsevier Academic Press, Brulington (MA), USA, 2007. 
[75] a) A.-C. Pöppler, M. M. Meinholz, H. Faßhuber, A. Lange, M. John, D. Stalke Organometallics 2012, 31, 42-45; b) W. Li, G. Kagan, R. Hopson, P. G. Williard, Arkivoc 2011, V, 180-187; c) D. Li, C. Sun, J. Liu, R. Hopson, W. Li, P. G. Williard, J. Org. Chem. 2008, 73, 2373-2381; d) M. Valentini, P. S. Pregosin, H. Rüegger, Organometallics 2000, 19, 2551-2555; e) I. Keresztes, P. G. Williard, J. Am. Chem. Soc. 2000, 122, 10228-10229; f) A. Hassinen, I. Moreels, C. d. M. Donegá, J. C. Martins, Z. Hens, J. Phys. Chem. Lett. 2010, 1, 2577-2581.

[76] J. Heinzer, J. F. M. Oth, D. Seebach, Helv. Chim. Acta 1985, 68, 1848-1862.

[77] a) D. Neuhaus, M. P. Williamson, in The Nuclear Overhauser Effect in Structural and Conformational Analysis, VCH, New York, USA, 1989; b) A. M. Gronenborn, G. M. Clore, Prog. NMR Spectr. 1985, 17, 1-36.

[78] M. B. Smith, J. March, in March's Advanced Organic Chemistry, 6. ed., Wiley-Interscience, Hoboken (NJ), USA, 2007.

[79] a) C. D. Broaddus, J. Org. Chem. 1970, 35, 10-15; b) M. Hage, C. A. Ogle, T. L. Rathman, J. L. Hubbard, Main Group Met. Chem. 1998, 21, 777-781.

[80] 2006,

[81] D. Barr, W. Clegg, R. E. Mulvey, R. Snaith, J. Chem. Soc., Chem. Commun. 1984, 226-227.

[82] A. V. Yakimansky, A. H. E. Müller, M. Van Beylen, Macromolecules 2000, 33, 5686-5692.

[83] D. Watkin, J. Appl. Crystallogr. 2008, 41, 491-522.

[84] T. Schulz, K. Meindl, D. Leusser, D. Stern, J. Graf, C. Michaelsen, M. Ruf, G. M. Sheldrick, D. Stalke, J. Appl. Crystallogr. 2009, 42, 885-891.

[85] P. J. Brown, A. G. Fox, E. N. Maslen, M. A. O'Keefe, B. T. M. Willis, in International Tables for Crystallography, Vol. C, Mathematical, Physical and Chemical Tables (Ed.: E. Prince), International Union of Crystallography, Chester, 2006, pp. 554-595.

[86] A.-C. Pöppler, 2013, private communication on 2D-NMR experiments.

[87] F. Bosold, P. Zulauf, M. Marsch, K. Harms, J. C. W. Lohrenz, G. Boche, Angew. Chem. 1991, 103, 1497-1499; Angew. Chem. Int. Ed. Engl., 30, 1455-1457.

[88] W. A. Busing, H. A. Levy, J. Chem. Phys. 1965, 42, 3054-3059.

[89] a) C. Drost, C. Jäger, S. Freitag, U. Klingebiel, M. Noltemeyer, G. M. Sheldrick, Chem. Ber. 1994, 127, 845-847; b) N. Kuhn, U. Abram, C. Maichle-Mößmer, J. Wiethoff, Z. Anorg. Allg. Chem. 1997, 623, 1121-1124; c) W. Clegg, A. M. Drummond, R. E. Mulvey, S. T. Liddle, Chem. Commun. 1998, 2391-2392; d) M. P. Coles, P. B. Hitchcock, Chem. Commun. 2005, 3165-3167; e) M. M. Meinholz, E. Carl, E. Kriemen, D. Stalke, Chem. Commun. 2011, 47, 10948-10950.

[90] a) R. L. Burwell, Jr., Chem. Rev. 1954, 54, 615-685; b) A. Maercker, Angew. Chem. 1987, 99, 1002-1019; Angew. Chem. Int. Ed. Engl., 26, 972-989.

[91] a) M. N. Uddin, M. A. Mottalib, N. Begum, S. Ghosh, A. Raha, K., D. T. Haworth, S. V. Lindemann, T. A. Siddiquee, D. W. Bennett, G. Hogarth, E. Nordlander, S. E. Kabir, Organometallics 2009, 28, 1514-1523; b) S. Ghosh, A. K. Das, N. Begum, D. T. Haworth, S. V. Lindemann, J. F. Gardinier, T. A. Siddiquee, D. W. Bennett, E. Nordlander, G. Hogarth, S. E. Kabir, Inorg. Chim. Acta 2009, 362, 5175-5182; c) S. S. Lee, T.-Y. Lee, D. S. Choi, J. S. Lee, Y. K. Chung, Organometallics 1997, 16, 1749-1756.

[92] M. A. Reynolds, I. A. Guzei, R. J. Angelici, J. Am. Chem. Soc. 2002, 124, 1689-1697.

[93] C. Bianchini, A. Meli, Synlett 1997, 643-649.

[94] a) S. Ghosh, G. Hogarth, D. A. Tocher, E. Nordlander, S. E. Kabir, Inorg. Chim. Acta 2010, 363, 1611-1614; b) N. K. K. Kazemifar, M. J. Stchedroff, M. A. Mottalib, S. Selva, M. Monari, E. Nordlander, Eur. J. Inorg. Chem. 2006, 2058-2068; c) M. A. Mottalib, S. E. Kabir, D. A. Tocher, A. J. Deeming, E. Nordlander, J. Organomet. Chem. 2007, 692, 5007-5016.

[95] a) M. N. Uddin, N. Begum, M. R. Hassan, G. Hogarth, S. E. Kabir, M. A. Miah, E. Nordlander, D. A. Tocher, Dalton Trans. 2008, 6219-6230; b) H. Topsoe, B. S. Clausen, F. E. Massoth, in Hydrotreating Catalysis: Science and Technology, Springer-Verlag, Berlin, 1996; c) D. D. Whitehurst, T. Isoda, I. Mochida, Adv. Catal. 1998, 42, 345-471; ; d) R. J. Angelici, in Encyclopedia of Inorganic Chemistry, Vol. 3 (Ed.: R. B. King), Wiley, 1994, pp. 1433-1443.

[96] U.S Department of Energy, U.S. Energy Information Administration, (05.12.2012): http://www.eia.gov/cfapps/ipdbproject/iedindex3.cfm?tid=5\&pid=5\&aid=2\&cid=ww,\&syid=20 11 \&eyid=2011\&unit=TBPD.

[97] V. Meyer, Chem. Ber. 1883, 36, 1465-1478.

[98] N. S. Nasri, J. M. Jones, V. A. Dupont, A. Williams, Energy Fuels 1998, 12, 1130-1134. 
[99] a) C. Amari, S. Ianelli, C. Pelizzi, G. Pelizzi, G. Predieri, Inorg. Chim. Acta 1993, 211, 89-94; b) S. Liu, C. R. Lucas, M. J. Newlands, J.-P. Charland, Inorg. Chem. 1990, 29, 4380-4385; c) R. J. Angelici, Coord. Chem. Rev. 1990, 105, 61-76; d) G. C. van Stein, G. van Koten, F. Blank, L. C. Taylor, K. Vrieze, A. L. Spek, A. J. M. Duisenberg, A. M. M. Schreurs, B. Kojic-Prodic, C. Brevard, Inorg. Chim. Acta 1985, 98, 107-120.

[100] Y. Yang, N. Zhao, Y. Wu, H. W. Roesky, Inorg. Chem. 2012, 51, 2425-2431.

[101] N. Derrien, C. B. Dousson, S. M. Roberts, U. Berens, M. J. Burk, M. Ohff, Tetrahedron: Asymmetry 1999, 10, 3341-3352.

[102] D. Stern, M. Granitzka, T. Schulz, D. Stalke, Z. Naturforsch., B: Chem. Sci. 2010, 65b, 719-724.

[103] a) K. Tamao, K. Sumitani, M. Kumada, J. Am. Chem. Soc. 1972, 94, 4374-3476; b) K. Tamao, J. Organomet. Chem. 2002, 653, 23-26.

[104] a) W. Zuo, C. Toubillon, V. Rosa, K. Cheaib, M. M. Andrade, S. Dagorne, R. Welter, Inorg. Chim. Acta 2012, 383, 213-219; b) J. Cho, Y.-M. Lee, S. Y. Kim, W. Nam, Polyhedron 2010, 29, 446-450; c) L. Latos-Grazynski, J. Lisowski, M. M. Olmstead, A. L. Balch, Inorg. Chem. 1989, 28, 11831188.

[105] L. Brammer, E. D. Stevens, Acta Crystallogr., Sect. C. 1989, C45, 400-403;

[106] Cambridge Structural Database, v5.33 (November 2012), Cambridge Crystallographic Data Centre, Cambridge, 2012.

[107] a) I. Andrés-Tomé, J. Fyson, F. B. Dias, A. P. Monkman, G. lacobellis, P. Coppo, Dalton Trans. 2012, 41, 8669-8674; b) S. J. Lippard, K. M. Melmed, Inorg. Chem. 1967, 6, 2223-2228; c) M. F. Cain, R. P. Hughes, D. S. Glueck, J. A. Golen, C. E. Moore, A. L. Rheingold, Inorg. Chem. 2010, 49, 7650-7662.

[108] a) C. R. Lucas, S. Liu, M. J. Newlands, J.-P. Charland, E. J. Gabe, Can. J. Chem. 1998, 67, 639-647; b) L. R. Hanton, C. Richardson, W. T. Robinson, J. M. Turnbull, Chem. Commun. 2000, 24652466; c) A. Doshi, K. Venkatasubbaiah, A. L. Rheingold, F. Jäkle, Chem. Commun. 2008, 4264 4266; d) G. C. v. Stein, G. v. Koten, K. Vrieze, A. L. Spek, E. A. Klop, C. Brevard, Inorg. Chem. 1985, 24, 1367-1375; e) G. C. v. Stein, G. v. Koten, A. L. Spek, A. J. M. Duisenberg, E. A. Klop, Inorg. Chim. Acta 1983, 78, L61-L63.

[109] G. W. J. Fleet, C. J. Fuller, P. J. C. Harding, Tetrahedron Lett. 1978, 16, 1437-1440.

[110] a) H. Araki, K. Tsuge, Y. Sasaki, S. Ishizaka, N. Kitamura, Inorg. Chem. 2005, 44, 9667-9675; b) A.M. Larsonneur-Galibert, P. Castan, J. Jaud, G. Bernardinelli, Transition Met. Chem. 1996, 21, 546-550; c) C. Di Nicola, G. A. Koutsantonis, C. Pettinari, B. W. Skelton, N. Somers, A. H. White, Inorg. Chim. Acta 2006, 359, 215-2169; d) A. Jouaiti, M. Geoffrey, G. Bernardinelli, J. Chem. Soc., Dalton Trans. 1994, 1985-1688.

[111] W. Li, Y. Han, B. Li, C. Liu, Z. Bo, J. Poly. Sci., Part A: Polym. Chem. 2008, 46, 4556-4563;

[112] D. Pou, C. López, S. Pérez, X. Solans, Font-Bardía, P. W. N. M. v. Leeuwen, G. P. F. v. Strijdonck, Eur. J. Inorg. Chem. 2010, 1642-1648.

[113] X. Fang, J. G. Watkin, B. L. Scott, G. J. Kubas, Organometallics 2001, 20.

[114] O. Clot, M. O. Wolf, B. O. Patrick, J. Am. Chem. Soc. 2001, 123, 9963-9973.

[115] S. Vuoti, J. Autio, M. Laitila, M. Haukka, J. Pursiainen, Eur. J. Inorg. Chem. 2008, 397-407.

[116] S. Vuoti, M. Haukka, J. Pursiainen, J. Organomet. Chem. 2007, 5044-5052.

[117] A. R. Burgoyne, R. Meijboom, H. Chiririwa, L. Kirsten, Acta Crystallogr., Sect. E. 2012, 68, m588.

[118] M. S. Balakrishna, D. Suresh, P. P. George, J. T. Mague, Polyhedron 2006, 25, 3215-3221;

[119] a) R. H. Crabtree, Acc. Chem. Res. 1979, 12, 331-337; ; b) M. C. Perry, X. Cui, M. T. Powell, D.-R. Hou, J. H. Reibenspies, K. Burgess, J. Am. Chem. Soc. 2002, 125, 113-123; ; c) A. Pfaltz, H. Blankenstein, R. Hilgraf, E. Hörmann, S. Mclntyre, F. Menges, M. Schönleber, S. P. Smidt, B. Wüstenberg, N. Zimmermann, Adv. Synth. Catal. 2003, 345, 33-43.

[120] S. Sengupta, X. Shi, ChhemCatChem 2010, 2, 609-619.

[121] A. D. Melhado, J. Brenzovich, William E., A. D. Lackner, F. D. Toste, J. Am. Chem. Soc. 2010, 136, 8885-8887.

[122] T. L. Stott, M. O. Wolf, B. O. Patrick, Inorg. Chem. 2005, 44, 620-627.

[123] N. C. Baenzinger, W. E. Bennett, D. M. Sobroff, Acta Crystallogr. 1976, B32, 962-963.

[124] a) H. Schmidbaur, Gold Bull. 2000, 33, 3-10; b) H. Schmidbaur, Chem. Soc. Rev. 1995, 24, 391400.

[125] a) P. G. Jones, J. Lautner, Acta Crystallogr., Sect. C. 1985, 44, 2089-2091; b) C. Strasser, W. F. Gabrielli, C. Esterhuysen, O. B. Schuster, S. D. Nogai, S. Cronje, H. G. Raubenheimer, New J. 
Chem. 2008, 32, 138-150; c) P. Sevillano, O. Fuhr, O. Hampe, S. Lebedkin, C. Neiss, R. Ahlrichs, D. Fenske, M. M. Kappes, Eur. J. Inorg. Chem. 2007, 33, 5163-5167.

[126] a) C. A. Tolman, Chem. Rev. 1977, 77, 313-348; b) M. Kranenburg, P. C. Kamer, P. W. N. M. van Leeuwen, Eur. J. Inorg. Chem. 1998, 155-157;

[127] A. F. Hollemann, N. Wiberg, in Lehrbuch der Anorganischen Chemie, 102. ed., Walter de Gruyter, Berlin, 2007.

[128] V. A. Naumov, A. V. Naumov, S. Samdal, Russ. J. Gen. Chem. 2007, 77, 553-560.

[129] A. S. Batsanov, S. M. Cornet, K. B. Dillon, A. E. Goeta, P. Hazendonk, A. L. Thompson, J. Chem. Soc., Dalton Trans. 2002, 4622-4628.

[130] A. S. Batsanov, S. M. Cornet, L. A. Crowe, K. B. Dillon, R. K. Harris, P. Hazendonk, M. D. Roden, Eur. J. Inorg. Chem. 2001, 2001, 1729-1737.

[131] K. Moedritzer, L. Maier, L. C. D. Groenweghe, J. Chem. Eng. Data 1962, 7, 307-310.

[132] V. Vicente, A. Fruchier, M. Taillefer, C. Combes-Chamalet, I. J. Scowen, F. Plénat, H.-J. Christau, New J. Chem. 2004, 28, 418-424.

[133] J. Clayden, N. Greeves, S. Warren, P. Wothers, in Organic Chemistry, 1. ed., Oxford University Press, New York (USA), 2001.

[134] F. Yang, P. E. Fanwick, C. P. Kubiak, Organometallics 1999, 18, 4222-4225.

[135] P. Rademacher, in Strukturen organischer Moleküle, VCH, New York, 1987.

[136] T. Steiner, Angew. Chem. 2002, 114, 50-80; Angew. Chem. Int. Ed., 41, 48-78.

[137] E. Lindner, C. Scheytt, Z. Naturforsch. 1986, 41b, 10-17.

[138] G. W. Brown, in The Chemistry of the Hydroxl Group (Ed.: S. Patai), Interscience, London, 1971.

[139] S. S. Chaudhari, K. G. Akamanchi, Synlett 1999, 11, 1763-1766.

[140] S. S. Kulkarni, P. Grundt, T. Kopajtic, J. L. Katz, A. H. Newman, J. Med. Chem. 2004, 47, 33883398.

[141] R. Appel, Angew. Chem. 1975, 87, 863-874; Angew. Chem. Int. Ed., 14, 801-812.

[142] A. Aguado, J. Boulos, A. Carreras, A. Monotoya, J. Rodriquez, J. Heterocycl. Chem. 2007, 44, 1517-1520.

[143] K. Issleib, A. Tzschach, Chem. Ber. 1959, 9, 1118-1126.

[144] M. A. Beswick, D. S. Wright, Coord. Chem. Rev. 1998, 176, 373-406.

[145] a) D. V. Partyka, M. P. Washington, T. G. Gray, J. B. Updegraff III, J. F. Turner II, J. D. Protasiewicz, J. Am. Chem. Soc. 2009, 131, 10041-10048; b) Y. Teramoto, K. Kubo, Mizuta, J. Organomet. Chem. 2011, 696.

[146] M. Scheer, L. J. Gregoriades, M. Zabel, J. Bai, I. Krossing, G. Brunklaus, H. Eckert, Chem. Eur. J. 2008, 14, 282-295.

[147] D. R. Armstrong, D. Barr, W. Clegg, S. R. Drake, R. J. Singer, R. Snaith, D. Stalke, D. S. Wright, Angew. Chem. 1991, 103, 1702-1704; Angew. Chem. Int. Ed. Engl., 30, 1707-1709.

[148] S. D. Harper, A. J. Arduengo III., J. Am. Chem. Soc. 1982, 104, 2497-2501.

[149] L. H. Koole, W. J. M. v. d. Hofstad, H. Buck, J. Org. Chem. 1985, 50, 4381-4383.

[150] W. Schlenk, in Die Methoden der Organischen Chemie, 2. Aufl. ed. (Ed.: J. Houben), G. Thieme, Leipzig, 1924, p. 720.

[151] W. G. Kofron, L. M. Baclawski, J. Org. Chem. 1976, 41, 1879-1880.

[152] BrukerCorporation, in Almanac 2011 Analytical Tables and Product Overview, 2011.

[153] in Bruker AXS Inst. Inc., WI, USA, Madison, 2011.

[154] in Bruker AXS Inst. Inc., WI, USA, Madison, 2009.

[155] W. Kabsch, J. Appl. Crystallogr. 1988, 21, 916-924.

[156] G. M. Sheldrick, Göttingen, 2008.

[157] G. M. Sheldrick, in TWINABS v1.05 in Bruker APEX v2.1-0 (Ed.: Bruker AXS Inst. Inc.), WI, USA, Madison, 2005.

[158] G. M. Sheldrick, in XPREP Version 2005/2 for Windows (Ed.: Bruker AXS Inst. Inc.), WI, USA, Madison, 2005.

[159] G. M. Sheldrick, Acta Crystallogr., Sect. A. 2008, 64, 112-122.

[160] C. B. Hübschle, G. M. Sheldrick, B. Dittrich, J. Appl. Cryst. 2011, 44, 1281-1284.

[161] C. F. Macrae, I. J. Bruno, J. A. Chisholm, P. R. Edgington, P. McCabe, E. Pidcock, L. RodriguezMonge, R. Taylor, J. van de Streek, P. A. Wood, J. Appl. Crystallogr. 2008, 41, 466-470. 
[162] P. Müller, R. Herbst-Irmer, A. L. Spek, T. R. Schneider, M. R. Sawaya, in Crystal Structure Refinement - A Crystallographer's Guide to SHELXL, Vol. 8 (Ed.: P. Müller), Oxford University Press, Oxford (England), 2006.

[163] A. Gerisch, M. Ruck, Z. Kristallogr. 2011, 266, 613-618.

[164] R. S. Ghadwal, S. S. Sen, H. W. Roesky, M. Granitzka, D. Kratzert, S. Merkel, D. Stalke, Angew. Chem. 2010, 122, 4044-4047; Angew. Chem. Int. Ed., 49, 3952-3955.

[165] R. S. Ghadwal, H. W. Roesky, M. Granitzka, D. Stalke, J. Am. Chem. Soc. 2010, 132, 10018-10020.

[166] R. S. Ghadwal, H. W. Roesky, C. Schulzke, M. Granitzka, Organometallics 2010, 29, 6329-6333.

[167] R. Azhakar, R. S. Ghadwal, H. W. Roesky, M. Granitzka, D. Stalke Organometallics 2012, 31, 5506-5510.

[168] P. P. Samuel, R. Azhakar, R. S. Ghadwal, S. S. Sen, H. W. Roesky, M. Granitzka, J. Matussek, D. Stalke Inorg. Chem. 2012, 51, 11049-11054.

[169] T. K. Sen, A. Mukherjee, A. Modak, P. K. Ghorai, D. Kratzert, M. Granitzka, D. Stalke, S. K. Mandal, Chem. Eur. J. 2012, 18, 54-58.

[170] A. P. Spork, D. Wiegmann, M. Granitzka, D. Stalke , C. Ducho, J. Org. Chem. 2011, 76, $10083-$ 10098.

[171] M. Büschleb, M. Granitzka, D. Stalke , C. Ducho, Amino Acids 2012, 36, 2313-2328.

[172] O. Ries, M. Granitzka, D. Stalke, C. Ducho, Synth. Commun. 2012, accepted.

[173] O. Ries, A. Ochmann, M. Granitzka, C. Ducho, in ORCHEM, Weimar, 2010.

[174] L. F. Tietze, N. Schützenmeister, A. Grube, T. Scheffer, M. M. Baag, M. Granitzka, D. Stalke Eur. J. Org. Chem. 2012, 29, 5748-5756.

[175] C. Brand, M. Granitzka, D. Stalke, D. B. Werz, Chem. Commun. 2011, 47, 10782-10784. 
